\title{
1986 Federal Interim Storage Fee Study: A Technical and Economic Analysis
}

September 1986

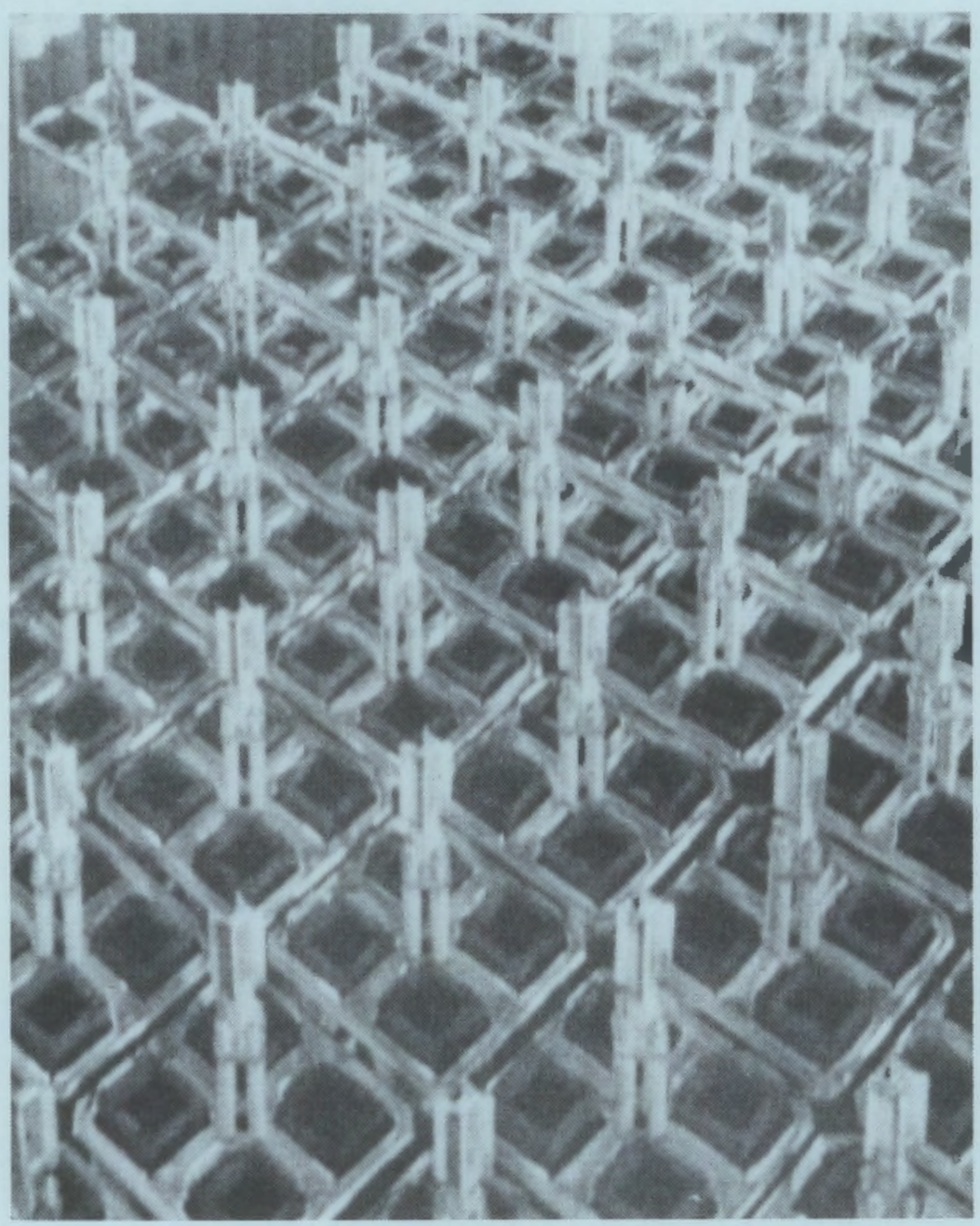

Prepared by E.R. Johnson Associates, Inc.

for Pacific Northwest Laboratory

under Contract DE-AC06-76RLO 1830

with the U.S. Department of Energy

Pacific Northwest Laboratory

Operated for the U.S. Department of Energy

by Battelle Memorial Institute 


\title{
DISCLAIMER
}

This report was prepared as an account of work sponsored by an agency of the United States Government. Neither the United States Government nor any agency thereof, nor any of their employees, makes any warranty, express or implied, or assumes any legal liability or responsibility for the accuracy, completeness, or usefulness of any information, apparatus, product, or process disclosed, or represents that its use would not infringe privately owned rights. Reference herein to any specific commercial product, process, or service by trade name, trademark, manufacturer, or otherwise, does not necessarily constitute or imply its endorsement, recommendation, or favoring by the United States Government or any agency thereof. The views and opinions of authors expressed herein do not necessarily state or reflect those of the United States Government or any agency thereof.

\author{
PACIFIC NORTHWEST LABORATORY \\ operated by \\ BATTELLE \\ for the \\ UNITED STATES DEPARTMENT OF ENERGY \\ under Contract DE-AC06-76RLO 1830
}

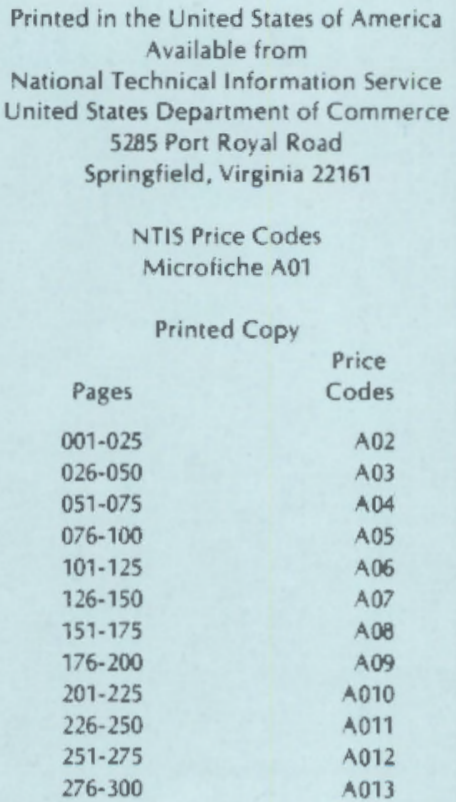


1986 FEDERAL INTERIM STORAGE FEE STUDY:

A TECHNICAL AND ECONOMIC ANALYSIS

E. R. Johnson Associates, Inc. Reston, Virginia

C. M. Heeb, PNL Project Manager

September 1986

Prepared by E. R. Johnson Associates, Inc. for Pacific Northwest Laboratory under Contract OE-AC06-76RL0 1830 with the U.S. Department of Energy under Agreement B-F7133-A-G

Pacific Northwest Laboratory

Richland, Washington 99352 


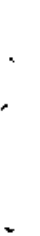

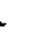




\section{TABLE OF CONTENTS}

1.0 INTROOUCTION

Page

2.0 SUMMARY AND CONCLUSIONS

2.0 SUMMARY AND CONCLUSIONS

3.0 BASES FOR THE STUDY 3-1

3.1 Storage Methods Considered

3.2 Quantities of Spent Fuel to be Stored

3.3 Location and Existing Capabilities of FIS Site

$3-1$

3.4 Schedule of Construction and Operation

3.5 Development of the Fee for FIS

3.6 Consol idated Spent Fuel

3-1

$3-1$

3-3

$3-4$

$3-4$

$3-5$

4.0 COSTS FOR FIS OF SPENT FUEL $4-1$

4.1 Review of and Revisions in FIS Facility Designs 4-1

4.2 Review of and Revisions in 1985 FIS Cost Estimates 4-1

5.0 COSTS FOR SPENT FUEL TRANSPORT

6.0 FEE METHODOLOGY ANO FEE COMPUTATION

6.1 Method of Fee Collection 6-1

6.2 Method of Computation of Fee 6-2

6.3 Sensitivity of Fees to Changes in Conditions $6-7$

6.4 Establishment of Fees for FIS Services 6-8

7.D SPENT FUEL ACCEPTANCE CRITERIA FOR FIS $7-1$

EXHIBIT A - DESIGN DESCRIPTION ANO ESTIMATED COSTS FOR THE DRY STORAGE OF SPENT NUCLEAR FUEL IN FEDERAL INTERIM STORAGE FACILITIES

EXHIBIT B - ESTIMATED COSTS FOR TRANSPORT OF SPENT FUEL FROM VARIOUS REACTOR SITES TO FEDERAL INTERIM STORAGE FACILITIES

EXHIBIT C - FIS SPENT FUEL ACCEPTANCE CRITERIA 
$1.0 \quad$ INTRODUCTION

The Nuclear Waste Policy Act of 1982 enacted on January 7, 1983 (Pub. L. 97-425, 96 Stat. 2201, 42 U.S.C. 10101 et seg., referred to herein as "the Act") established, among other things, a Federal Interim Storage (FIS) Program for spent nuclear fuel from domestic civilian power reactors. This program is intended to ensure the continued orderly operation of such reactors where at-reactor storage cannot reasonably be provided soon enough, as determined by the Nuclear Regulatory Commission (NRC), to prevent a disruption of operations. Sec. 136(a)(2) of the Act provides that the Secretary of Energy (the Secretary) undertake a study to establish payment charges for FIS of spent fuel and report the results to Congress not later than 180 days after the date of enactment of the Act.

In accordance with this requirement, the Department of Energy (the Department) prepared and submitted a report to Congress entitled payment Charges for Federal Interim Storage of Spent Nuclear Fuel from Civilian Nuclear Power Plants in the United States, DOE/S-0022, dated July 1983. The report was supplemented by a more detailed technical, contractual, and economic study and analys is which was contained in a report entitled Federal Interim Storage Fee Study for Civilian Spent Nuclear Fuel: A Technical and Economic Analysi.s, D0E/S-0023, dated July 1983. These reports formed the bas is for the payment charges for Federal Interim Storage (FIS) services which were pubtished in the Federal Register on December 2, 1983 and became effective on January 1,1984 (F.R. 48:54391).

Under the provisions of the Act, the Department may revise these payment charges no more frequently than annualiy to reflect changing conditions. In preparation for the possibility of a revision to the payment charges for FIS services for 1986, E. R. Johnson Associates, Inc. (JAI) was asked to review and analyze $00 E / S-0022$ and $00 E / S-0023$ and to update the content thereof to provide a basis for the Department to establish the payment 
charges $1 /$ for FIS services in the Federal Register for the year commencing January 1, 1986. The results of this update were reported in a document entitled, 1985 Federal Interim Storage Fee Study: A Technical and Economic Analysis, PNL-5559, dated September 1985.

in preparation for the possibility of a revision to the payment charges for FIS services for 1987 , JAI was asked to:

o Review the data base of information that was used in the previous fee deterninations.

- Prepare estimates of costs for capital, operating, and decomissioning each of the FIS facilities cases reported on in PNL-5559.

- Update spending schedules for each of the FIS facilities cases reported on in PNL -5559 .

- Review the fee structure to ensure that it will recover government expenses in a way that eliminates or minimizes the need for appropriations of federal funds to provide FIS. Since it is the Department's current position that funds will not be appropriated for FIS purposes and that procurements will be authorized only from funds available in the Interim Storage Fund, it is important that the fee structure provides funds for FIS expenditures in advance of the time the expenditures are made.

o Recommend the magnitude of the fee to be collected from FIS users based on the background information and fee structure reviews noted adove.

As a result of this work, JAI has updated the content of PNL-5559 to provide a basis for the Department to establish payment charges for FIS services in the Federal Register for the year commencing January 1, 1987. This report describes the results of the update which was performed.

If The terms "payment charges", "charges", "fee" and "unit cost" have been used interchangeably throughout this report and, therefore, have identical meanings. 
JAI examined alternative methods for structuring charges for FIS services and concluded that the combined interests of the Department and the users would be best served, and costs most appropriately recovered, by a twopart fee involving an Initial Payment upon execution of a contract for FIS services followed by a Final Payment upon delivery of the spent fuel to the Department.

The Initial Payment would be an advance payment covering the pro rata share of preoperational costs, including (i) the capital costs of the required transfer facilities and storage area, (ii) development costs, (iti) government administrative costs including storage fund management, (iv) impact aid payments made in accordance with section $136(e)$ of the Act, and ( $v$ ) module costs (i.e., storage casks, drywells or silos).

The Final Payment would be made at the time of delivery of the spent fuel to the Department and would be calculated to cover the sum of the following:

(i) any under-or over-estimation in the costs used to calculate the Initial Payment of the fee (including savings due to rod consolidation), and

(ij) the total estinated cost of operation and decommissioning of the FIS facilities (including government administrative costs, storage fund management and impact aid).

The module costs were included in the Initial payment to preclude the possible need to obtain appropriations for federal funds to support the purchase of the modules in advance of receipt of the Final Payment.

Charges for the transport of spent fuel from the reactor site to FIS facilities would be separately assessed at actual cost since these will be specific to each reactor site and destination.

The Initial payments received from all users would provide the funds necessary to design, license (as applicable) and construct the FIS facilities, to pay for storage modules, and to repay any funds borrowed from the U.S. Treasury that may have been needed earlier. The Final Payments received would also include an adjustment for differences between the actual preoperational costs and those used to calculate the Initial Payment, and the estimated future costs of facility operation. 
JAI estimated the charges that would have to be made for the FIS of commercial spent fuel by each of three different methods of dry storage. These estimates were made for facilities having storage capacities ranging from 50-1900 MTU2/ at each of two different types of government sites, one which has an existing hot cell for the transfer of spent fuel from shipping casks to the storage modules, and one which does not. The determination of this range of charges was necessary inasmuch as the method of FIS has not yet been seiected, the selection of a specific location(s) for FIs facilities has not been initiated, and the quantity of spent fuel which may become eligibie to be stored in FIS facilities has not yet been determined. The total estimated charges developed by JAI are set forth in Tabie 2-1; the corresponding Initial payments and Final Payments are set forth in Tables $2-2$ and $2-3$.

TABLE 2-1

ESTIMATE OF THE TOTAL UNIT CHARGES FOR FIS SERVICES AT THE INOICATED FIS CAPACITY LEYELS FOR EACH OF THE ALTERNATIVE MODES OF STORAGE AND FACILITY LOCATION ${ }^{a}$,b (1987 Dollars)

Total FIS Fees ( $\$ / \mathrm{kgll})$

\begin{tabular}{|c|c|c|c|c|c|c|c|c|}
\hline \multirow{3}{*}{$\begin{array}{l}\text { Capacity } \\
\text { Of FIS } \\
\text { Facility } \\
\frac{\text { (MTU) }}{50}\end{array}$} & \multicolumn{3}{|c|}{$\begin{array}{l}\text { At Site Without } \\
\text { Existing Transfer Facilities }\end{array}$} & \multicolumn{5}{|c|}{$\begin{array}{c}\text { At Site With } \\
\text { Existing Transfer Facilities }\end{array}$} \\
\hline & $\begin{array}{l}\text { Storage } \\
\text { Cask }\end{array}$ & Drye: & $\$ 110$ & & $\begin{array}{l}\text { rage } \\
\text { ask }\end{array}$ & Drywell & & ilo \\
\hline & $\$ 1,089$ & $\$ 1,169$ & $\$ 1,097$ & $\$$ & 628 & 5833 & $s$ & 760 \\
\hline 100 & 632 & 646 & 614 & & 402 & 478 & & 446 \\
\hline 300 & 313 & 285 & 279 & & 236 & 230 & & 223 \\
\hline 800 & 211 & 173 & 176 & & 182 & 151 & & 154 \\
\hline 1500 & 184 & 139 & 144 & & 167 & 126 & & 130 \\
\hline 1900 & 177 & 131 & 135 & & 164 & $12 I$ & & 124 \\
\hline
\end{tabular}

Excludes cost for transport of spent fuel since this will be specific to each reactor site and destination

Based on two-thirds of the weight of uranium being contained in PWR assemblies with a $0.461 \mathrm{kJU}$ loading and one-third of the weight of uranium being contained in BUR assemblies with a 0.183 MTV loading.

2/MTU stands for metric tons of uranium contained in the fuel assemblies at first introduction into the reactor. kgU represents kilograms of uranium contained in the fuel assemblies at first introduction into the reactor. 1 MTU $=1000 \mathrm{kgU}$ 
TABLE 2-2

ESTIMATED INITIAL PAYMENT FOR FIS SERVICES

AT THE INDICATED INITIAL FIS CAPACITY LEVELS FOR EACH OF THE

ALTERNATIVE MDOES OF STORAGE ${ }^{a}, b$

(1987 Dollars)

Initial Payment ( $\$ / \mathrm{kgU})$

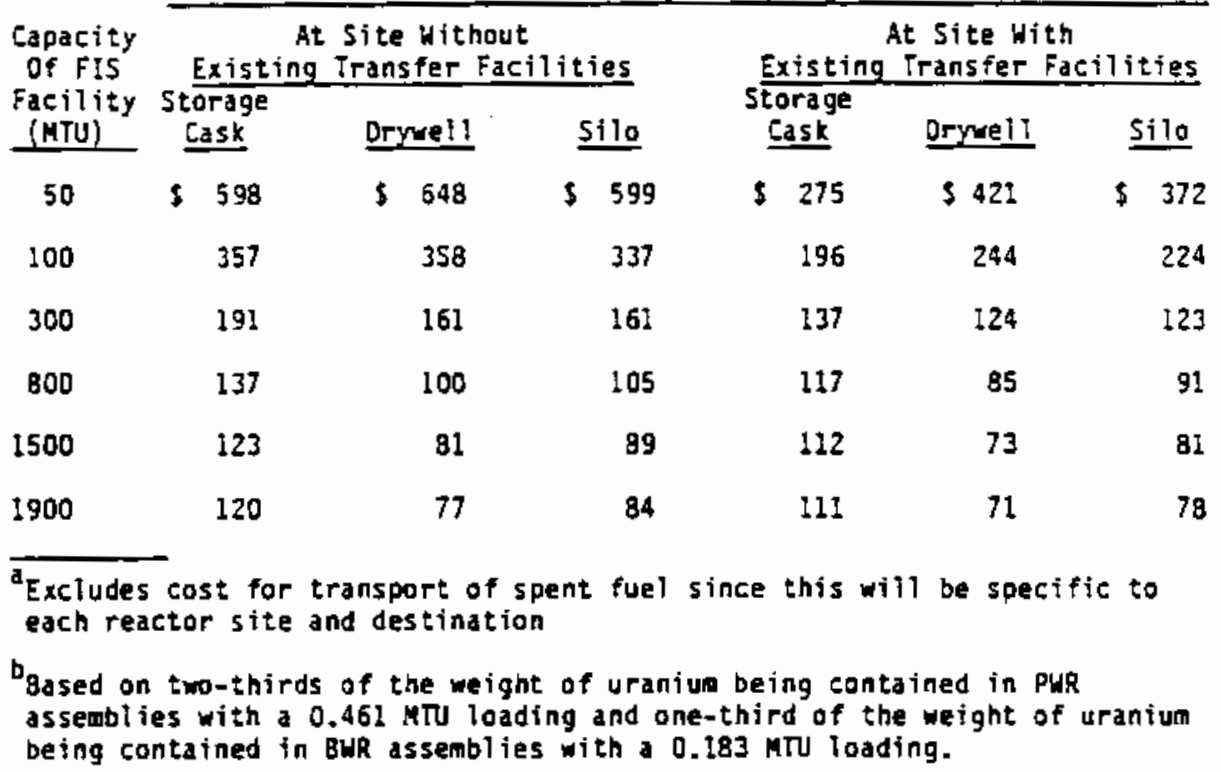

TABLE 2-3

ESTTMATED FIMAL PAYMENT FOR FIS SERVICES

AT THE INDICATED INITIAL FIS CAPACITY LEVELS FOR EACH OF THE ALTERMATIVE MODES OF STORAGE ${ }^{2} \mathrm{~S}$

(1987 Dollars)

Final Payment $(\$ / \mathbf{k g u})$

\begin{tabular}{|c|c|c|c|c|c|c|c|c|c|c|}
\hline \multirow{2}{*}{$\begin{array}{c}\text { Capacity } \\
\text { of FIS } \\
\text { Facility } \\
\text { (MU) }\end{array}$} & \multicolumn{5}{|c|}{$\begin{array}{l}\text { At site Without } \\
\text { Existing Transfer Factlities }\end{array}$} & \multicolumn{5}{|c|}{$\begin{array}{l}\text { At Site With } \\
\text { Existing Transfer Facilities }\end{array}$} \\
\hline & $\begin{array}{c}\text { Storage } \\
\text { Cask }\end{array}$ & & well & & 10 & & $\begin{array}{l}\text { rage } \\
\text { sk }\end{array}$ & Oryweli & & iio \\
\hline 50 & $\$ 491$ & $\$$ & 521 & $s$ & 498 & $\$$ & 353 & $\$ 412$ & $\$$ & 388 \\
\hline 100 & 275 & & 288 & & 277 & & 206 & 234 & & 222 \\
\hline 300 & 122 & & 124 & & 118 & & 99 & 106 & & 100 \\
\hline 800 & 74 & & 73 & & 71 & & 65 & 56 & & 63 \\
\hline 1500 & 61 & & 58 & & 55 & & 55 & 53 & & 49 \\
\hline 1900 & 57 & & 54 & & 51 & & 53 & 50 & & 46 \\
\hline
\end{tabular}

Excludes cost for transport of spent fuel since this will be specific to each reactor site and destination

based on two-thirds of the weight of uranium being contained in 9w8 assembl ies with a 0.451 mrJ loading and ane-third of the weight of urarium being contained in BUR assemblies ith a 0.183 MTU loading. 
The magnitude of the total unit charges set forth in Table 2-1 was about the same as that set forth in the 1985 report; in some instances the unit charges were slightly higher and in other instances they were slightly lower. This was due to the fact that escalation of costs was offset by the shorter period of time over wh ch the FIS progran would be in effect until its completion in 2001 and the cost savings assocjated therewith (the storage program in this report spanned the period from 1987 through 2001 , while that in the 1985 report spanned the period from 1985 through 2001).

JAI also estimated the costs of transporting spent fuel between each of twenty-two reactor sites which are prospective candidates for Fis services and two sample locations for FIS facilities, one in the Eastern U.S. and one in the Western U.S. It was found that costs for shipments made under NRC and DOT regulations averaged from $\$ 10 / \mathrm{kgU}$ to $\$ 38 / \mathrm{kgU}$ for a FIS facility located in the Eastern U.S., and averaged from $\$ 40 / \mathrm{kgU}$ to $\$ 83 / \mathrm{kgU}$ for a FIS facility located in the Western U.S., depending on the mode of shipment involved. These estimates are subject to change because of uncertainties in shipping cask design, licensing and fabrication costs, and the possible impact of carrier deregulation.

In view of the limited amount of spent fuel that is expected to be received for Fis compared to the total amount of spent fuel stored at reactor locations, and the requirements of the Act that the Department recover the costs associated with the FIS program, it is recommended that the Department (i) establish fees for FIS and the method of collection thereof in the manner described in Section 6.0 of this report, (ji) accept only non-defective spent fuel assemblies and canistered consolidated fuel rods meeting specific acceptance criteria, (iij) require specific measurements and calculations to be made on the fuel and loaded casks delivered to the Department to support certifications with respect to the condition thereof, and (iv) obtain reimbursement for additional costs incurred as a result of its receiving defective fuel or shipping casks that are not delivered in full accordance with specific certifications required by the Department, in addition to the published charges for FIS services. 
The overall bases for 00E/S-0023, PNL-5231, and PNL-5559 (which are subsequently referred to herein as the 1983 report, the 1984 report, and the 1985 report, respectively) were reviewed and evaluated with respect to applicability for estabiishing charges for FIS services for the calendar year 1987. The following sections summarize the bases used for establishing the 1987 charges.

\subsection{STORAGE METHODS CONSIDERED}

For the purposes of this study, JAI used the same basic assumptions with respect to the methods of storage to be considered for FIS purposes that were used in the 1983,1984 and 1985 reports:

(1) that the FIS of spent fuel would be accomplished using dry, modular methods of storage inasmuch as these methods offer the greatest flexibility in meeting changing requirements for storage capacity, and

(2) since the Department has yet to select the specific method of storage, this study considered storage by one design each of three classes of dry, modular methods including metal storage casks, drywells (or caissons below-grade), and concrete storage silos (or caissons above-grade).

JAI continues to recommend that the Department not make the selection of a specific method for use in FIS until the first contract(s) for FIS services is executed.

While the Department has continued to consider the possibility of using existing water basin storage facilities which may be avaliable at government sites for FIS purposes, the feasibility and economics of the use of such facilities for FIS still have not been established. Therefore, the use of such facilities has not been considered in this study as a basis for estabilishing payment charges for FIS services for calendar year 1987.

\subsection{QUANTITIES OF SPENT FUEL TO BE STOREO}

The prospective needs of utility companies for spent fuel storage are expected to amount to about 203 MTU in 1988 increasing to as much as 813 MTU in 1991, as described in the following Table 3-1. $\underline{3,4 /}$

3/Spent Fuel Storage Requirements An Update of DOE/RL-85-2, DOE/RL-86-5, September 1986.

4/ If a requirement for FIS services occurs before 1989 , this requirement would be met by temporary storage at existing Department facilities. 
TABLE 3-1

PROSPECTIVE SOURCES OF SPENT FUEL FOR FIS

Metric Tons Initial Heavy Metal

\begin{tabular}{|c|c|c|c|c|c|c|c|c|c|}
\hline Reactor & $\underline{1986}$ & $\underline{1987}$ & 1988 & $\underline{1989}$ & $\underline{1990}$ & 1991 & $\underline{1992}$ & 1993 & $\underline{1994}$ \\
\hline Surry $1 \& 2$ & 27 & 27 & 71 & 121 & 145 & 170 & 218 & 242 & 266 \\
\hline Palisades & 0 & $?$ & 7 & 34 & 60 & 60 & 87 & 87 & 113 \\
\hline Oconee $1 \& 2$ & 0 & 44 & 72 & 100 & 155 & 183 & 238 & 266 & 322 \\
\hline St. Lucie 1 & 0 & 2 & 30 & 30 & 57 & 86 & 86 & 115 & 144 \\
\hline Millstone 1 & 0 & 23 & 23 & 59 & 59 & 95 & 95 & 130 & 166 \\
\hline Robinson 2 & 0 & 0 & 0 & 0 & 17 & 38 & 38 & 63 & 84 \\
\hline Brunswick 1 & 0 & 0 & 0 & 0 & 29 & 29 & 64 & 64 & 98 \\
\hline La Salle CTY 1 \& 2 & 0 & 0 & 0 & 0 & 26 & 66 & 146 & 186 & 226 \\
\hline Peach Bottom 2 & 0 & 0 & 0 & 0 & 20 & 61 & 61 & 102 & 142 \\
\hline Brunswick 2 & 0 & 0 & 0 & 0 & 0 & 7 & 7 & 41 & 76 \\
\hline Peach Bottom 3 & 0 & 0 & 0 & 0 & 0 & 18 & 56 & 56 & 94 \\
\hline Calvert $\mathrm{Cl}$ iffs $1 \& 2$ & 0 & 0 & 0 & 0 & 0 & 0 & 11 & 45 & 80 \\
\hline Pilgrim 1 & 0 & 0 & 0 & 0 & 0 & 0 & 28 & 28 & 63 \\
\hline La Crosse & 0 & 0 & 0 & 0 & 0 & 0 & 1 & 4 & 7 \\
\hline Oconee 3 & 0 & 0 & 0 & 0 & 0 & 0 & 19 & 19 & 46 \\
\hline Prairie Island $1 \& 2$ & 0 & 0 & 0 & 0 & 0 & 0 & 0 & 6 & 35 \\
\hline Byron $1 \& 2$ & 0 & 0 & 0 & 0 & 0 & 0 & 0 & 0 & 6 \\
\hline Indian Point 2 & 0 & 0 & 0 & 0 & 0 & 0 & 0 & 0 & 8 \\
\hline B Valley 1 & 0 & 0 & 0 & 0 & 0 & 0 & 0 & 0 & 23 \\
\hline Oyster Creek 1 & 0 & 0 & 0 & 0 & 0 & 0 & 0 & 0 & 27 \\
\hline Cooper STN & 0 & 0 & 0 & 0 & 0 & 0 & 0 & 0 & 7 \\
\hline Millstone 2 & 0 & 0 & 0 & 0 & 0 & 0 & 0 & 0 & 18 \\
\hline Fort Calhoun & 0 & 0 & 0 & 0 & 0 & 0 & 0 & 0 & 1 \\
\hline Davis-Besse 1 & $\underline{0}$ & 0 & $\underline{0}$ & 0 & $\underline{0}$ & 0 & $\underline{0}$ & $\underline{0}$ & 4 \\
\hline TOTAL & 27 & 103 & 203 & 343 & 570 & 813 & 1156 & 1456 & 2057 \\
\hline
\end{tabular}

${ }^{a}$ Differences between the sum of the quantities of spent fuel from individual reactors and the annual totals shown are due to computer rounding. 
However, it may be possible for many, if not all, of the utility campanies which have the expected shortfall in spent fuel storage capacity to meet all or part of their additional storage needs through transshipments, rod consolidation 5/, installation of additional capacity at reactor sites, or combinations thereof. Moreover, the NRC may, during the determination of eligibility, find that much of the spent fuel currently forecast to exceed available on-site storage capacity will not qualify for FIS.

In view of the uncertainties associated with predicting the amount of spent fuel to be received for FIS, this study considered storage in facilities having the following nominal capacities for each of the storage methods considered up to the limitation of 1900 MTU as established by the Act :
(1) 50 MTU
(4) $800 \mathrm{MTU}$
(2) $100 \mathrm{MTU}$
(5) 1500 MTU
(3) 300 MTU
(6) $1900 \mathrm{MTU}$

\subsection{LOCATION AND EXISTING CAPABILITIES OF FIS SITE}

As in the 1983, 1984 and 1985 studies, this study continued to consider the use of two generic types of government sites - - one assumed to have existing facilities for transferring spent fuel from shipping casks to storage modules, and a second without such facilities. It was assumed that NRC licensing would apply to all FIS activities except the modification and operation of an existing transfer facility. UAI also estimated the costs involved in shipping spent fuel to sites in both the Eastern and the Western U.S. A site for FIS of spent fuel probably will not be specified until there are clear indications that FIS services will be required.

JAI reviewed the prospect of locating FIS facilities at reactors, as permitted by Sec. $135(a)(1)(B)$ and (C) of the Act, but concluded that the Department probably could not develop storage capability at such locations sooner than utility companies acting on their own. For these and the other reasons set forth in the 1983, 1984 and 1985 reports, the possibility of locating $F$ IS facilities at reactors was not considered further in this study.

$5 /$ Rod consolidation consists of removing fuel rods from the fuel assembly structure and placing then in a safe, close-packed array (in canisters) that occupies less space than the original fuel assembly. 
For the purposes of factoring the time value of money into the fee calculations of this study, JAI assumed the following concerning the schedule of constructing and operating FIS facilities in developing the revenue/expenditure schedules:

(1) Design, licensing (as applicable) and construction of FIS facilities would commence in 1987 and be completed so that storage operations could commence in mid-1990.

(2) The FIS facility would receive spent fuel during the threeyear period between mid-1990 and mid-1993. It would ship spent fuel to a Monitored Retrievable Storage (MRS) facility or waste repository during the three-year period commencing at the beginning of 1998 and terminating at the end of 2000 . One third of the storage capacity of the FIS facility would be received each year during the receiving period, and one-third would be shipped each year during the shipping period.

(3) Decontamination and decommissioning of FIS facilities would be conducted in the year 2001 .

This schedule represents a one-year compression of the FIS program over that used in the 1985 report (and a three-year schedule compression over that of the 1983 report) inasmuch as the program has been assumed to start one year later, but ends at the same t:me as was assumed before.

\subsection{OEVELOPMENT OF THE FEE FOR FIS}

The same basic assumptions concerning the development of charges for FIS of spent fuel were used by JAI in this study as were used in the development of the 1985 report, as follows:

(1) The charges for FIS would inciude the cost of

(a) design, 1 icensing and construction of FIS facilities,

(b) storage modules,

(c) research and development solely related to the development of FIS facilities,

(d) operating costs which are incremental to the operation of the government site(s) at which the FIS facilities are located, 
(e) government administration associated with FIS of spent fuel, including storage fund management,

(f) impact aid, and

(g) decontamination and decomissioning of the FIS facilities at the end of their useful $1 \mathrm{ife}$.

(2) The charges for transport of spent fuel from the reactor locations to the FIS facilities would be separately included inasmuch as they would be specific to each point of origin and destination, and would be charged directly to the utility.

(3) The fee developed for FIS of spent fuel would cover all costs of the FIS system for storage as aforementioned through the year 2000 and for the decommissioning period.

\subsection{CONSOLIDATED SPENT FUEL}

For this study JAI continued to assume that canistered consolidated spent fuel rods would be acceptable for storage at the fIS facilities, but that consolidation would not be a criterion for acceptance, nor would the disassembly and consolidation of spent fuel be included in the capabilities of the FIS facilities. It would be expected that the Department would collect the same fee for storage of canistered consolidated spent fuel rods as for intact fuel assemblies until the cost effects of storing consolidated fuel become known. However, the cost of transporting consolidated spent fuel rods from the reactors to FIS facilities is expected to be about 0.6 of that involved in transporting intact fuel assemblies and, therefore, would result in a significant reduction in costs for utilities sending consolidated spent fuel to FIS. 

4.0 COSTS FOR FIS OF SPENT FUEL

4.I REVIEW OF AND REVISIONS IN FIS FACILITY DESIGNS

In the development of the 1984 report, there were severai design changes made to FIS facilities. During the course of this study a review was made of the resultant facility designs used in the 1984 report and it was concluded that no further design changes were either necessary or desirabie for the development of FIS payment charges for 1987 .

\subsection{REVIEW OF AND REVISIONS IN 1985 FIS COST ESTIMATES}

The estimates of the capital costs for transfer facilities and storage areas used in the development of the 1983 report, portions of which were modified in the 1984 report, were escalated to 1987 dollars using appicable cost indexes.

The estimates of the cost of concrete silos and drywells, and the estimates of government administration costs which were used in the development of the this report, were the same as those used for the 1983 report, escalated to 1987 dollars using applicable cost indexes. The estimate of the cost of canisters used in the development of this report were the same as those used for the 1984 report, escalated to 1987 dollars using applicable cost indexes. The estimates of cost of metal storage casks was derived from 1986 cost infomation obtained from cask design firms. For the purposes of this report, these 1986 costs were escalated to 1987 dollars.

The estimates of operating costs used in the development of the this report were were the same as those developed in the 1983 report, escalated to 1987 dollars.

The estimates of FIS development costs set forth in the 1983 report were reviewed and it was concluded that the same estimates would be applicable for use herein, escalated to 1987 dollars.

A description of the alternative facility designs, details of the associated cost estimates, and FIS system spending schedules are set forth in Exhibit $A$ of this report.

Table 4-1 sets forth the total capital costs for the cases studied. The capital costs include (i) the cost of the transfer/encapsulation facilities, or modifications to existing hot cell facilities which can be used 
for transfer/encapsulation, (ii) the cost of the storage area, and ( $i i j$ ) the cost of the storage modules.

TABLE 4-1

SUMMARY OF ESTIMATED CAPITAL COSTS FOR FIS FACILITIES

HAVING DIFFERENT TOTAL STORAGE CAPACITIES

(\$-millions, 1987)

Total Capital Cost

\begin{tabular}{|c|c|c|c|c|c|c|}
\hline \multirow{2}{*}{$\begin{array}{l}\text { Capacity } \\
\text { of FIS } \\
\text { Facility } \\
\text { (MTU) }\end{array}$} & \multicolumn{3}{|c|}{$\begin{array}{c}\text { At Site without } \\
\text { Existing Transfer Facilities }\end{array}$} & \multicolumn{3}{|c|}{$\begin{array}{c}\text { At Site With } \\
\text { Existing Transfer Facilities }\end{array}$} \\
\hline & $\begin{array}{l}\text { Storage } \\
\text { Cask }\end{array}$ & Drywell & silo & $\begin{array}{l}\text { Storage } \\
\text { Cask }\end{array}$ & Drywe ll & $\underline{\text { Silo }}$ \\
\hline 50 & $\$ 27.0$ & $\$ 29.5$ & $\$ 27.0$ & $\$ 10.3$ & $\$ 17.8$ & $\$ 15.3$ \\
\hline 100 & 32.8 & 32.6 & 30.5 & 16.0 & 20.9 & 18.8 \\
\hline 300 & 54.7 & 44.9 & 44.8 & 38.0 & 33.2 & 33.1 \\
\hline 800 & 108.9 & 75.5 & 80.3 & 92.1 & 63.8 & 68.5 \\
\hline 1500 & 186.0 & 118.1 & 130.0 & 169.3 & 106.4 & 118.2 \\
\hline 1900 & 229.8 & 142.5 & 158.4 & 213.0 & 130.8 & 146.6 \\
\hline
\end{tabular}

Based on two-thirds of the weight of uranium being contained in PWR assemblies with a 0.461 MTU loading and one-third of the weight of uranium being contained in BWR assemblies with a 0.183 MTU loading.

From the capital cost data shown in Table 4-1, it can be seen that for the lower capacities (less than $100 \mathrm{MTU}$ ) the capital cost of storage cask facilities is the lowest while the drywell facilities are the highest. However, at the higher capacities (more than 300 MTU) the capital cost of drywell facilities is the lowest while the storage cask facilities are the highest. This is due to the following:

(1) the cost of the transfer facilities is lower in the case of storage casks than for the other two cases

(2) the cost of the storage area is lowest for the cask and highest for the drywell because of the larger size of the latter 
(3) the cost of moduies is lowest for the drywell and highest for the cask

(4) at higher capacities, the cost advantages described in (1) and (2), above, are more than offset by the higher module cost of the storage casks.

The capital costs for all cases are obviously less where an existing facility exists which can be modified for transfer/encapsulation purposes. However, cask storage requires considerably less modification to an existing facility (hot cell) than the other modes of storage since no encapsulation facilities are required.

Table 4-2 sets forth the total operating costs for the cases studied.

TABLE 4-2

SUMMARY OF ESTIMATED TOTAL OPERATING COSTS FOR FIS FACILITIES HAVING DIFFERENT TOTAL STORAGE CAPACITIES ${ }^{\mathrm{a}}$

(\$-millions, 1987)

Total Operating Cost

\begin{tabular}{|c|c|c|c|c|c|c|}
\hline \multirow{2}{*}{$\begin{array}{l}\text { Capacity } \\
\text { of FIS } \\
\text { Facility } \\
\text { (MTU) }\end{array}$} & \multicolumn{3}{|c|}{$\begin{array}{c}\text { At Site Without } \\
\text { Existing Transfer Facilities }\end{array}$} & \multicolumn{3}{|c|}{$\begin{array}{l}\text { At Site with } \\
\text { Existing Transfer Facilities }\end{array}$} \\
\hline & $\begin{array}{l}\text { Storage } \\
\text { Cask }\end{array}$ & Drywe 11 & Silo & $\begin{array}{l}\text { Sorage } \\
\text { Cask }\end{array}$ & Drywell & silo \\
\hline 50 & $\$ 25.0$ & $\$ 26.6$ & $\$ 25.4$ & $\$ 17.2$ & $\$ 20.4$ & $\$ 19.1$ \\
\hline 100 & 26.7 & 28.1 & 26.9 & 18.9 & 21.9 & 20.6 \\
\hline 300 & 33.4 & 34.0 & 32.1 & 25.6 & 27.8 & 25.9 \\
\hline 800 & 51.1 & 49.5 & 48.6 & 42.9 & 43.1 & 41.2 \\
\hline 1500 & 77.3 & 73.6 & 68.6 & 68.0 & 65.7 & 60.5 \\
\hline 1900 & 92.2 & 87.4 & 80.0 & 82.2 & 78.6 & 71.6 \\
\hline
\end{tabular}


From the operating costs shown in Table 4-2, it can be seen that the operating costs associated with storage casks are the lowest for the lower capacity facilities (100 MTU and less), while those associated with the silos are the lowest for the higher capacity facilities ( 800 MTU and more). Operating costs at the site with an existing transfer facjlity are lower than those at a site where a complete transfer facility has to be built, inasmuch as in the latter case it was assumed that a small caretaker operation would be required for the new facility, whereas in the former case it was assumed that the existing facility would either find other use during the storage-only period or otherwise would have incurred caretaker expense in the absence of the FIS facility located at the site.

Table 4-3 sets forth the total costs of special charges which are applicable to each of the cases studied. These include (i) research and development costs associated with the development of the FIs facilities, (ii) government administration costs for the FIS program including storage fund management, and (jii) impact aid.

TABLE 4-3

SUMMARY OF ESTIMATED SPECIAL COSTS FOR FIS FACILITIES

HAVING DIFFERENT TOTAL STORAGE CAPACITIES

(\$-millions, 1987)

Total Special Cost

\begin{tabular}{|c|c|c|c|c|c|c|}
\hline \multirow{2}{*}{$\begin{array}{c}\text { Capacity } \\
\text { Of Fis } \\
\text { Facility } \\
\text { (MTU) } \\
\end{array}$} & \multicolumn{3}{|c|}{$\begin{array}{l}\text { At Site Without } \\
\text { Existing Transfer Facilities }\end{array}$} & \multicolumn{3}{|c|}{$\begin{array}{l}\text { At Site With } \\
\text { Existing Transfer Facilities }\end{array}$} \\
\hline & $\begin{array}{l}\text { Storage } \\
\text { Cask }\end{array}$ & Drywell & silo & $\begin{array}{l}\text { Storage } \\
\text { Cask }\end{array}$ & Orywe 11 & Silo \\
\hline 50 & $\$ 6.2$ & $\$ 6.2$ & $\$ 6.2$ & $\$ 6.2$ & $\$ 6.2$ & $\$ 6.2$ \\
\hline 100 & 8.3 & 8.3 & 8.3 & 8.3 & 8.3 & 8.3 \\
\hline 300 & 13.1 & 13.1 & 13.1 & 13.1 & 13.1 & 13.1 \\
\hline 800 & 23.5 & 23.5 & 23.5 & 23.5 & 23.5 & 23.5 \\
\hline 1500 & 37.2 & 34.2 & 35.7 & 37.2 & 32.7 & 32.7 \\
\hline 1900 & 44.8 & 39.1 & 41.0 & 44.8 & 39.1 & 39.1 \\
\hline
\end{tabular}

\footnotetext{
aased on two-thirds of the weight of uranium being contained in PWR assemblies with a 0.461 MTU loading and one-third of the weight of uranium being contained in BWR assembiles with a 0.183 MTU loading.
} 
From Tabie 4-3 it can be seen that special costs remain the same at a given capacity for all modes of storage through the 800 MTU capacity level. This is due to the fact that the FIS development costs are the same for all cases, the government administration costs are the same at each capacity level, and the impact aid is fixed at $\$ 15 / \mathrm{kg} \mathrm{U}$. The Act establishes a maximum for impact aid amounting to $\$ 15 / \mathrm{kg} U$ or $10 \%$ of all costs, whichever is smaller. In the capacity cases through 800 MTU, $10 \%$ of the costs is higher than $\$ 15 / \mathrm{kg} \mathrm{U}$, thus $\$ 15 / \mathrm{kg} \mathrm{U}$ was used in these cases. However, in some of the cases above the 800 MTU capacity level, $10 \%$ of the costs is lower than $\$ 15 / \mathrm{kg}$ $U$ and was used, thus producing a variation among the cases considered at these capacity levels.

Table 4-4 sets forth the total discounted costs of construction and operation of the FIS storage system for each of the cases studied. These costs include the sum of all capital costs, operating costs and special costs (except impact aid) -- discounted to 1987 at 2 percent/year.

TABLE 4-4

SUMMARY OF TOTAL DISCOUNTEO COSTS FOR CONSTRUCTION ANO OPERATIONS

OF FIS FACILITIES HAVING DIFFERENT TOTAL STORAGE CAPACITIES ${ }^{a, b}$

$$
\text { (\$-millions, 1987) }
$$

Total Discounted Costs (Discounted o $2 \% / \mathrm{yr}$ to 1987)

\begin{tabular}{|c|c|c|c|c|c|c|}
\hline \multirow{2}{*}{$\begin{array}{l}\text { Capacity } \\
\text { of Fis } \\
\text { Facility } \\
\text { (MTU) } \\
\end{array}$} & \multicolumn{3}{|c|}{$\begin{array}{c}\text { At Site Without } \\
\text { Existing Transfer Facilities }\end{array}$} & \multicolumn{3}{|c|}{$\begin{array}{l}\text { At Site With } \\
\text { Existing Transfer Facilities }\end{array}$} \\
\hline & $\begin{array}{l}\text { Storage } \\
\text { Cask }\end{array}$ & Orywell & Silo & $\begin{array}{l}\text { Storage } \\
\text { Cask }\end{array}$ & Orywe l ] & Silo \\
\hline 50 & $\$ 51.6$ & $\$ 55.5$ & $\$ 52.0$ & $\$ 29.2$ & $\$ 39.2$ & $\$ 35.6$ \\
\hline 100 & 59.5 & 60.7 & 57.6 & 37.1 & 44.4 & 41.2 \\
\hline 300 & 86.3 & 78.3 & 76.5 & 63.9 & 62.0 & 60.1 \\
\hline 800 & 152.5 & 121.4 & 124.9 & 129.7 & 105.1 & 107.6 \\
\hline 1500 & 246.8 & 183.1 & 189.3 & 223.1 & 165.4 & 171.5 \\
\hline 1900 & 300.1 & 218.1 & 225.9 & 275.8 & 199.6 & 207.7 \\
\hline \multicolumn{7}{|c|}{$\begin{array}{l}\text { aased on two-thirds of the weight of uranium being contained in PWR } \\
\text { assemblies with a } 0.461 \text { MTU loading and one-third of the weight of uranium } \\
\text { being contained in BWR assemblies with a } 0.183 \text { MTU loading. } \\
\text { boes not include impact aid. }\end{array}$} \\
\hline
\end{tabular}


From the total discounted costs shown in Table 4-4, it can be seen that for the lower capacities (50-100 MTU and less) the cost of storage in storage casks is less than the other two cases, with the cost of storage in drywelis being the highest. However, for the higher capacities ( 800 MTU and more), the cost of storage in drywells is less than the other two cases, with the cost of storage in storage casks being the highest. The cost of storage for all modes of storage are close to each other in the 100-300 MTU capacity range. The aforementioned relationships apply to both cases where transfer facilities exist at the FIS site and where they do not so exist, however, the total costs for storage by all storage methods are lower in the former case than they are in the latter. 
5.0 COSTS FOR SPENT FUEL TRANSPORT

Estimates were made of the cost of transporting fuel from most of

the prospective reactor locations identified in Table 3-1 of this report and FIS facility sites in the Eastern U.S. and the Western U.S. Estimated costs were developed for both truck transport and for rail transport, however, rail shipments should be used to the maximum extent feasible inasmuch as the larger payload of the rail casks significantly reduces the number of shipments and the amount of cask handling at both the reactor site and the FIS facilities.

Table 5-1 sets forth the estimated total cost of a single shipment of spent fuel between the various points of origin and destination considered in this study. 
TABLE 5-1

SUMMARY OF ESTIMATED COSTS FOR A SINGLE CASK SHIPMENT OF SPENT

FUEL FROM SPECIFIC REACTOR LOCATIONS TO FIS FACILITIES

(1987 0ollars)

Reactor to Destination

From Surry to

Eastern U.S. Site Western U.S. Site

From Palisades to Eastern U.S. Site Western U.S. Site

From St. Lucie to Eastern U.S. Site Western U.S. Site

From Robinson to Eastern U.S. Site Western U.S. Site

From Fitzpatrick to Eastern U.S. Site Western U.S. Site

From Brunswick to Eastern U.S. Site Western U.S. Site

From LaSalle to Eastern U.S. Site Western U.S. Site

From Oconee to Eastern U.S. Site Western U.S. Site

From Turkey Point to Eastern U.S. Site Western U.S. Site

From Monticello to Eastern U.S. Site Western U.S. Site

$\frac{\text { From Peach 8ottom to }}{\text { Eastern U.S. Site }}$ Western U.S. Site

From Pilgrim to Eastern U.S. Site Western U.S. Site

Total Cost for Shipment

Truck Shipments $^{a}$ Rail Shipments

$\$ 8,974$

25,035

9,905

20,455

11,835

30,943

7,416

30,850

12,926

26,258

9,144

30,231

9,169

18,062

6,338

26,842

13,148

32,415

13,946

15,757

11,135

26,811

12,706

29,238
$\$ 88,926$

218,676

76,316

160,273

99,075

218,172

72,557

204,950

88,907

202,795

74,288

206,267

82,451

157,929

80,748

211,919

101,846

281,187

108,429

143,983

93,360

203,497

120,304

231,052 
TABLE 5-I (Continued)

SUMMARY OF ESTIMATED COSTS FOR A SINGLE CASK SHIPMENT OF SPENT FUEL FROM SPECIFIC REACTOR LOCATIONS TO FIS FACILITIES

(1987 Dollars)

Reactor to Destination

From Ginna to

Eastern U.S. Site

Western U.S. Site

From Indian Point to

Eastern U.S. Site

Western U.S. Site

From Mills tone to Eastern U.S. Site Western U.S. Site

From Prairie Island to

Eastern U.S. Site

Western U.S. Site

From LaCrosse to

Eastern U.S. Site

Western U.S. Site

From Calvert Cliffs to

Eastern U.S. Site

Western U.S. Site

From Oyster Creek to

Eastern site

Western U.S. Site

From Cooper to

Eastern U.S. Site

Western U.S. Site

From Sequoyah to

Eastern U.S. Site

Western U.S. Site

From Davis Besse to

Eastern U.S. Site

Western U.S. Site
Total Cost for Shipment

$\overline{\text { Truck Shipments }}^{\text {a Rail Shipments }}$ b

$\$ 11,843$

25,038

$\$ 106,157$

209,436

14,284

107,221

28,302

215,899

12,234

109,133

2B, 710

217,521

13,749

91,722

18,347

143,825

12,161

89,820

16,885

143,863

9,387

91,146

26,821

218,153

11,262

101,378

29,140

217,466

13,289

91,602

15,298

138,545

4,548

52,647

24,453

196,641

9,911

73,272

21,465

\footnotetext{
a Based on use of NLI $1 / 2$ truck cask with capacity for either one PWR or two BWR fuel assemblies.

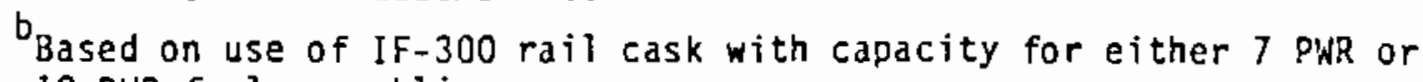
18 BWR fuel assemblies.
} 



\subsection{FEE METHODOLOGY AND FEE COMPUTATION}

6.1 METHOO OF FEE COLLECTION

JAI has reviewed the proposed method of fee collection set forth in the 1983,1984 and 1985 reports and the alternative methods that were considered therein, and has concluded that the combined interests of the Department and the FIS users would still be best served by a two-part fee involving an Initial Payment upon execution of a contract for FIS services, followed by a Final Payment upon delivery of the spent fuel to the Department.

The initial Payment represents an advance payment to cover the pro rata share of preoperational costs, including:

- the capital costs of the required transfer facilities and storage area

o module costs (i.e., storage casks, drywells, or silos)

o development costs

- government administrative costs including storage fund management

- impact aid payments made in accordance with section 136(e) of the Act, and

o interest on any Treasury funds advanced to the FIS program.

The Final Payment would cover the sum of the following:

- any under-or over-estimation in the costs used to calculate the Initial Payment of the fee (including savings due to rod consolidation)

- transportation costs (including cask lease, freight, handling and security) ${ }^{*}$, and

o the total estimated cost of operation and decommissioning of the FIS facilities (including government administrative costs, storage fund management and impact aid)

\#This cost is not included in the FIS payment charges schedule which is issued annuality by DOE. 
The Initial Payment received from all users would be calculated to provide the funds necessary to design, license (where applicable) and construct the FIS facilities, purchase storage modules, and repay any funds borrowed from the U.S. Treasury that may have been needed earlier. The Final Payments received would also include an adjustment for differences between the actual preoperational costs and those used to calculate the Initial Payment, and the estimated future costs of facility operation and decominissioning.

\subsection{METHOD OF COMPUTATION OF FEE}

The same method for computation of the fees for FIS services as was described in the 1983,1984 and 1985 reports was used in this study. This method is summarized below:

(1) In order to effect the recovery of costs incurred by the Department in providing FIS services, the fees for such services must be established such that the sum of the discounted costs of providing the services is equal to the sum of the discounted revenues received by the Department for such services, as follows:

Discounted Costs $=$ Discounted Revenues

Discounted Revenues $=$ Discounted (Luit Fee $x$ Units of Storage)

Discounted (Unit Fee $x$ Units of Storage) $=$

Unit Fee $x$ Discounted Units of Storage

(2) Since the fee is an unknown in the above equations, but the units of storage (MTU or numbers of modules) and estimated costs are known, the fee can be calculated by the following:

Unit Fee $=\frac{\text { Discounted Costs }}{\text { Discounted Units of Storage }}$

(3) Since it has been determined that: a two-part fee for FIS services is desirabie, and since a two-part fee would provide all required funds for the FIS of spent fuel either in advance of or at the same time that the corresponding component of cost of storage would be incurred, it is necessary to employ a discount rate equal to the "real" value of money, i.e., the value of money to the government net of escalation. The discount factor established by JAI for this purpose is 1.02 (or a $2 \%$ /year discount rate). 
Using the costs developed in Exhibit $A$, Section 9.0, the Initial Payments, Final Payments and total payments estimated to be required in 1987 dollars for the FIS of spent fuel are set forth in Tables $6-1,6-2$ and $6-3$, respectively -- for each of the three methods of storage, at the six different leveis of capacity, and the two different types of locations considered in this study. The costs of transport of the spent fuel from the various prospective reactor locations to two typical FIs facility locations have been excluded from the unit costs set forth in these tables but have been shown separately in Table 6-4.

TABLE 6-1

ESTIMATED INITIAL PAYMENT FOR FIS SERVICES

AT THE INDICATED INITIAL FIS CAPACITY LEVELS FOR EACH OF THE

ALTERNATIVE MODES OF STORAGE ${ }^{\mathrm{a}, \mathrm{b}}$

(1987 Dollars)

Initial Payment ( $\$ / \mathrm{kgU})$

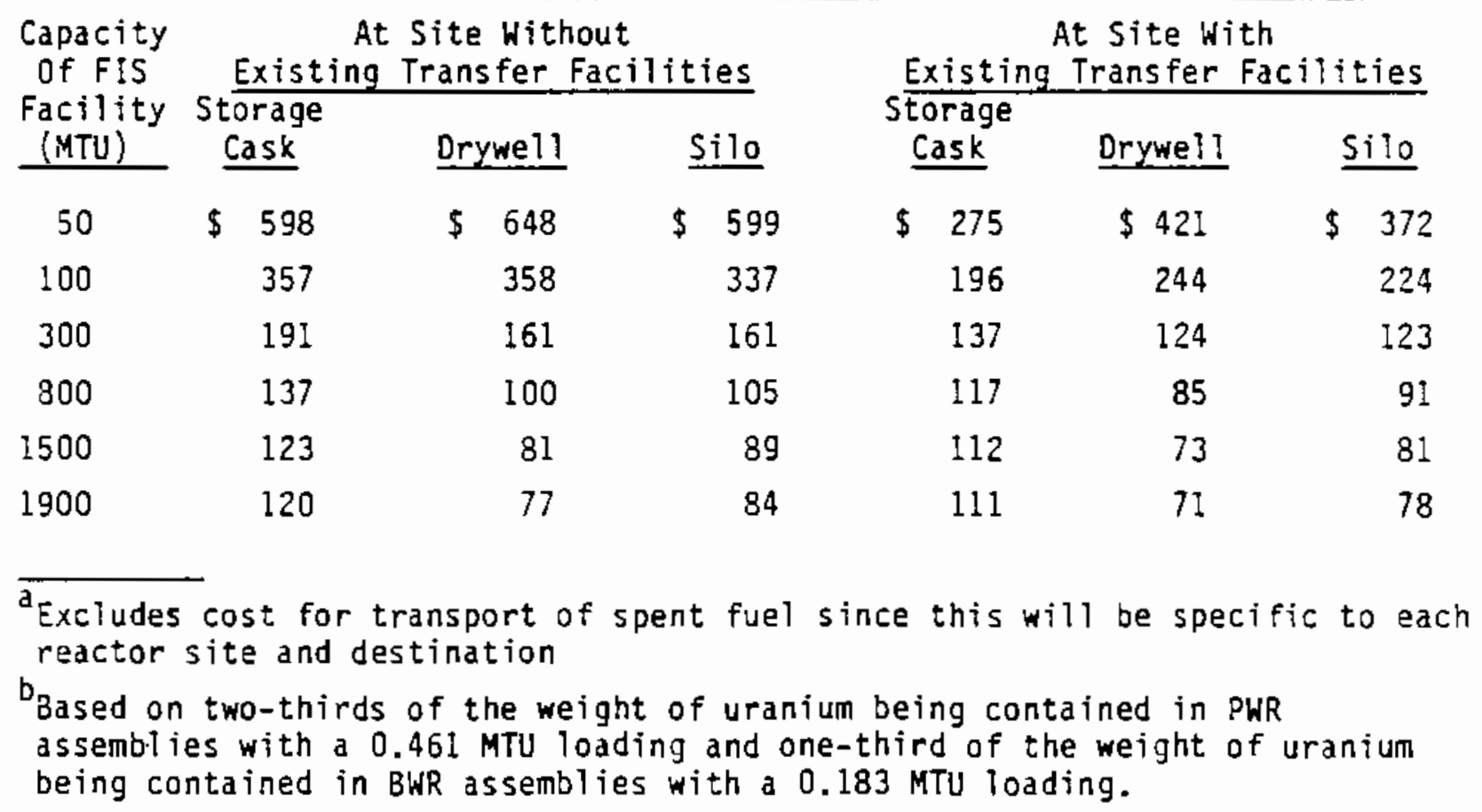


TABLE 6-2

ESTIMATED FINAL PAYMENT FOR FIS SERVICES

AT THE INOICATED IMITIAL FIS CAPACITY LEYELS FOR EACH OF THE ALTERNATIVE MODES OF STORAGE ${ }^{a}$,

(1987 Dotlars)

Final Payment (sikgu)

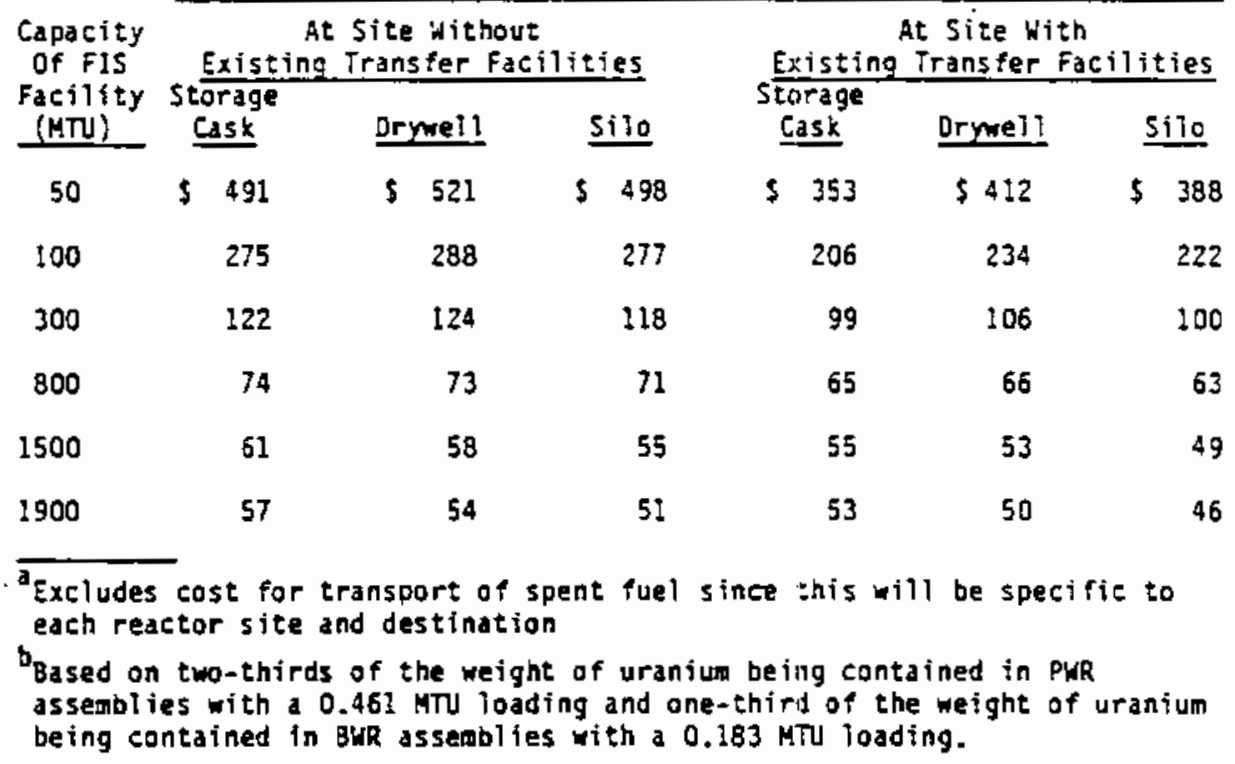

TABLE 6*3

ESTIMATED TOTAL UNIT COST FOR FIS SERVICES

AT THE INDICATED INITIAL FIS CAPACITY LEYELS FOR EACH OF THE ALTERMATIVE MOES OF STORAGE ${ }^{a}$,

(1997 Dollars)

Totai FIS Fees ( $s / \mathrm{kgd}$ )

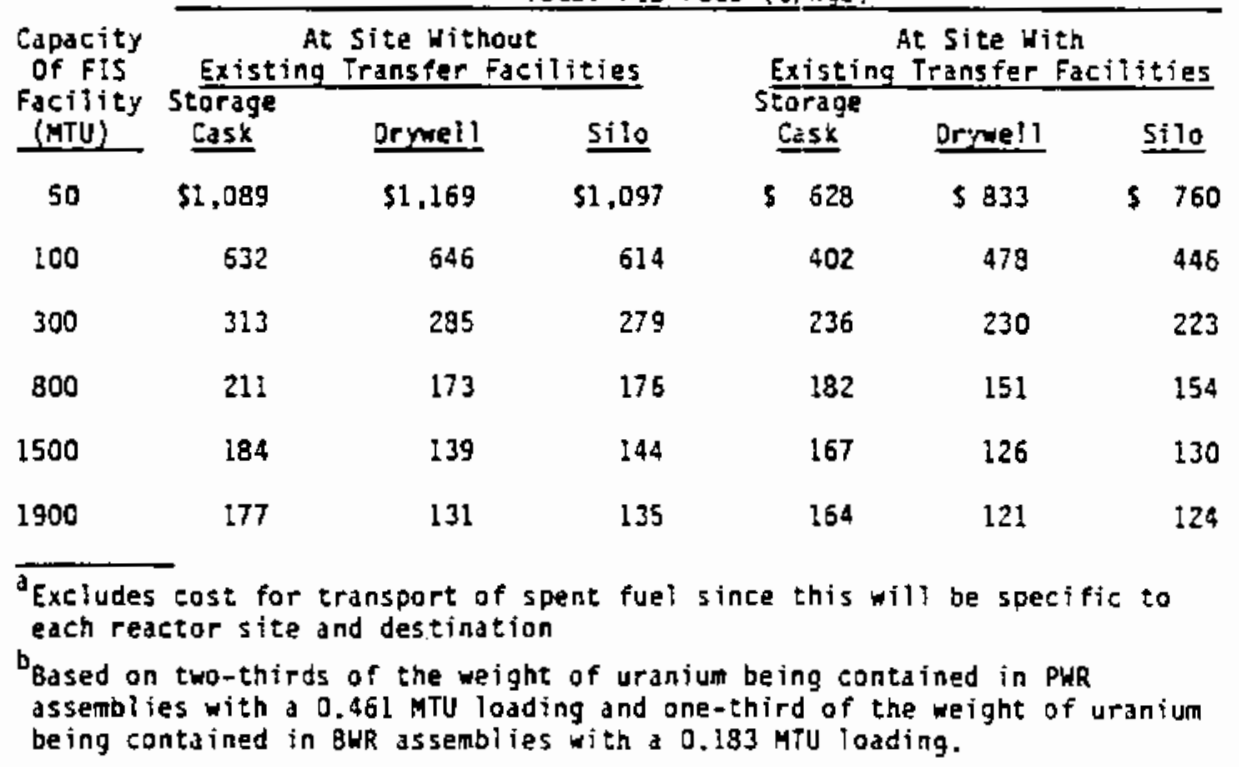


TABLE 6-4

SUMMARY OF ESTIMATED UNIT COSTS FOR TRANSPORTING SPENT FUEL FROM SPECIFIC REACTOR LOCATIONS TO FIS FACILITIES

(1987 Dollars)

Reactor to Destination

From Surry to

Eastern U.S. Site

Western U.S. Site

From $\mathrm{Pal}$ isades to

Eastern U.S. Site

Western U.S. Site

From St. Lucie to Eastern U.S. Site Western U.S. Site

From Robinson to Eastern U.S. Site Western U.S. Site

From Fitzpatrick to Eastern U.S. Site Western U.S. Site

From Brunswick to Eastern U.S. Site Western U.S. Site

From LaSalle to Eastern U.S. Site Western U.S. Site

From Oconee to Eastern U.S. Site Western U.S. Site

From Turkey Point to Eastern U.S. Site Western U.S. Site

From Monticello to Eastern U.S. Site Western U.S. Site

From Peach Bottom to Eastern U.S. Site Western U.S. Site

From Pilgrim to Eastern U.S. Site Western U.S. Site

From Ginna to Eastern U.S. Site Western U.S. Site

$\frac{\text { Total Cost for Shipment }(\$ / \mathrm{kgU})}{\text { By Truck }^{b}}$

$\$ 19.08$

$\$ 27.56$

54.31

67.76

21.48

23.65

44.37

49.67

25.67

30.70

67.12

67.61

16.09

22.48

66.92

63.51

35.32

26.99

71.74

$6 i .56$

24.98

22.55

82.60

62.62

25.05

25.03

49.35

47.94

13.75

25.02

58.23

65.67

28.52

31.56

70.32

67.61

38.10

32.92

43.05

43.71

30.42

28.34

73.25

61.78

34.72

36.52

79.88

70.14

25.69

32.90

54.31

64.90 
TABLE 6-4 (Continued)

SUMMARY OF ESTIMATED UNIT COSTS FOR TRANSPORTING SPENT FUEL FROM

SPECIFIC REACTOR LOCATIONS TO FIS FACILITIES

(1987 Dollars)

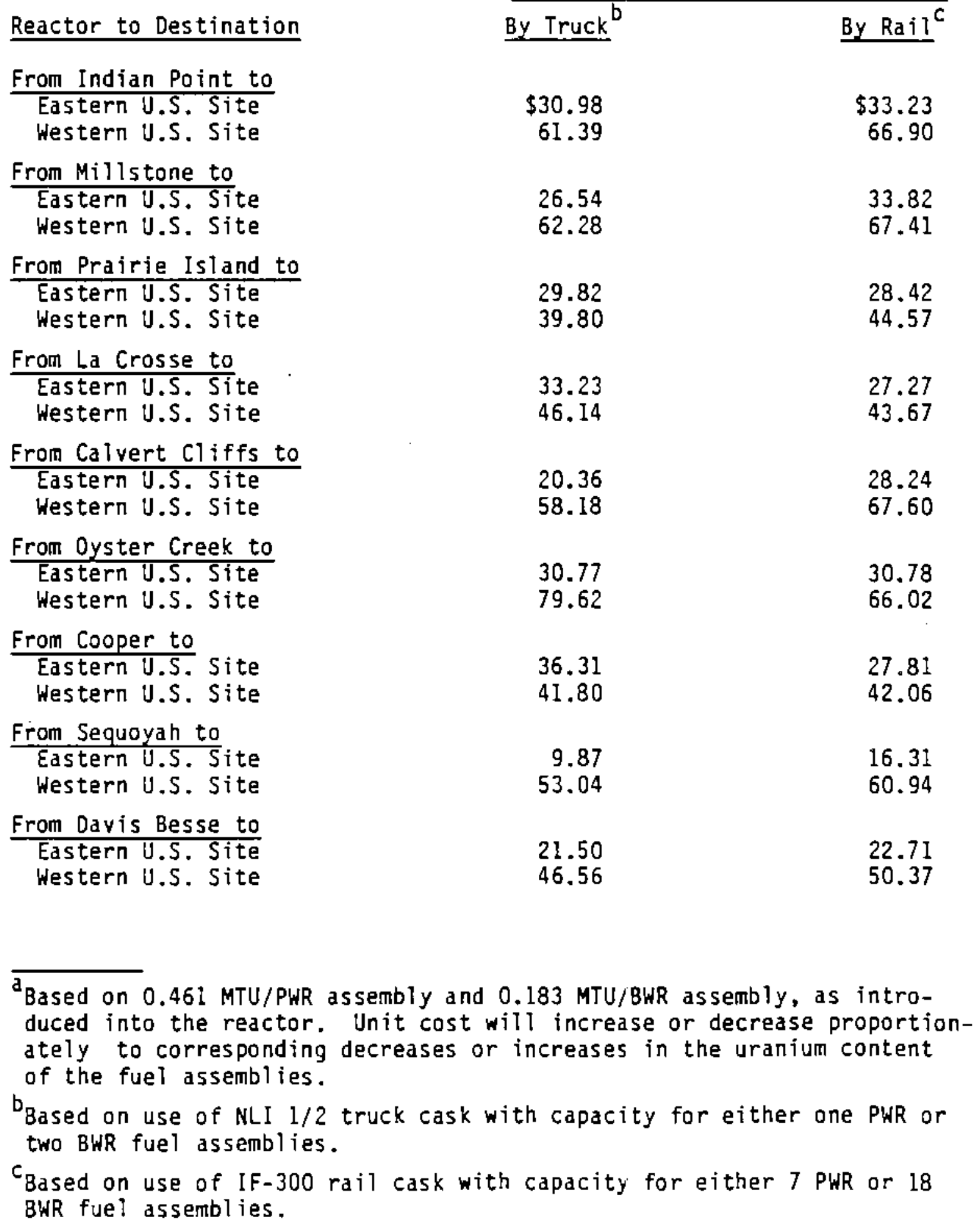

$\frac{\text { Total Cost for Shipment }(\$ / \mathrm{kgU})}{\text { By Truck }^{\mathrm{b}}}$

$\$ 30.98$

$\$ 33.23$

66.90

rom Millstone to

Eastern U.S. Site

26.54

33.82

29.82

28.42

Eastern U.S. Site

rom La Crosse to

Eastern U.S. Site

33.23

27.27

From Calvert $\mathrm{Cl}$ iffs to

Eastern U.S. Site

20.36

28.24

From Oyster Creek to

Eastern U.5. Site

30.77

30.78

Western U.S. Site

36.31

27.81

Eastern U.S. Site

41.80

16.31

9.87

60.94

rom Davis Besse to

Eastern U.S. Site

21.50

22.71

Western U.S. Site 


\subsection{SENSITIYITY OF FEES TO CHANGES IN CONDITIONS}

The sensitivity of the total fees- for Fls to changing conditions of cost, schedule, mix of spent fuel types, and discount rate, and to whether or not the facility was subject to NRC licensing, was determined for the drywell cases at storage capacity levels of 100 MTU and 1900 MTU (see Section 10.0 of Exhibit A). The results of these fee sensitivity studies are summarized below:

(1) A change of \$1-million in the capital cost of transfer facilities at the FIS site causes a corresponding change in the total fees for FIS of about $\$ 12 / \mathrm{kgU}$ at the 100 MTU capacity leyel, decreasing to about $\$ 1 / \mathrm{kgU}$ at the 1900 MTU capacity level.

(2) A change of $\$ 1,000$ in the cost of canisters or drywells causes a corresponding change in the total fees for FIS of about $\$ 3 / \mathrm{kgU}$ at all capacity levels.

(3) For each year the term of the FIS program is extended (due to delay in repository startup), there is an increase in the total fees for FIS at the 100 MTU capacity level of about $\$ 16 / \mathrm{kgU}$ for instances where a new transfer facility is built, and about $\$ 10 / \mathrm{kgU}$ for instances where an existing transfer facility can be utilized for FIS. These increases amount to about $\$ 2 / \mathrm{kgU}$ and $\$ 1 / \mathrm{kgU}$, respectively, at the 1900 MTU capacity level.

(4) For each year the time over which spent fuel is received for storage increases, there is a increase in the total fees for FIS at the 100 MTU capacity level of about $\$ 2 / \mathrm{kgU}$ for instances where a new transfer facility is built, and about $\$ 9 / \mathrm{kgU}$ for instances where an existing transfer facility can be utilized for FIS. There is little impact of the receipt schedule on total fees at the 1900 MTU capacity level.

(5) For each year the time for design, licensing, and construction of the initial FIS facilities decreases land, therefore, increasing the amount of time spent fuel is stored by a corresponding amount), there is an increase in the total fees for FIS at the 100 MTU capacity level of about $\$ 20 / \mathrm{kgU}$ for instances where a new transfer facility is built, and about $\$ 12 / \mathrm{kgU}$ for instances where an existing transfer facility can be utilized. These increases amount to about $\$ 2.5 / \mathrm{kgU}$ and $\$ 1 / \mathrm{kgU}$, respectively, at the 1900 MTU capacity level.

[/ The term "total fees" used in this section refers to the sum of the Initial and Final Payments. 
(6) A one kilogram decrease in the average amount of uranium contained in the spent fuel in a drywell from the $429 \mathrm{kgV}$ loading assumed for this study causes an increase in the total fees for FIS by about $\$ 0.20 / \mathrm{kgU}$, in the range of $366 \mathrm{~kg} U$ to $461 \mathrm{~kg} \mathrm{U}$. Conversely, a one kilogram increase in the average amount of uranium contained in a idrywell causes a decrease of $\$ 0.20 / \mathrm{kgl}$ in the total fees for FIS.

(7) An increase in the discount rate by one percentage point causes a decrease in the total faes for FIS at the 100 MTU capacity level of about $\$ 19 / \mathrm{kgU}$ for instances where a new transfer facility is built, and about $\$ 14 / \mathrm{kgJ}$ for instances where an existing transfer facility can be utilized for FIS. These decreases amount to about $\$ 4.5 / \mathrm{kgU}$ for cases at the 1900 MTU capacity level.

(8) Not having to follow the procedural (not safety) requirements involved in NRC licensing activities nor conform the FIS systems to NRC security requirements causes a decrease in the total fees for FIS by about $\$ 100 / \mathrm{kgU}$ at the 100 MTU capacity level decreasing to about $\$ 6 / \mathrm{kgll}$ at the 1900 MTU capacity level.

\subsection{ESTABLISHMENT OF FEES FOR FIS SERVICES}

JAI recommends that the Department establish its fee for FIS services in the same basic manner as it did in the 1983, 1984 and 1985 reports, and which is described below:

(1) The fee should be published in two parts -- an Initial Payment and a Final payment. The Final Payment should be subdivided into two components: one should include all cost components except transportation of spent fuel, and the other should include spent fuel transportation and associated costs between reactor locations and $F I S$ facilities.

(2) Upon publication, the Initial Payment, and the Final Payment for all cost components except transportation, should be firn until revised by a subsequent publication. The Department should plan to invoice the individual user for the actual cost the Department incurs in the transportation of the user's spent fuel to the FIS facilities.

(3) Until the Department has rece"ved commitments for FIS services, it should publish a fee schedule for a range of capacities from 100 MTU to the 1900 MTU 1 imit established by the Act.

(4) Until the Department detemines the location or locations for FIS facilities and the method or methods of storage to be used, the fee that represents the highest cost(s) for the combin- 
ation of types of location(s) and storage method(s) under consideration should apply.

(5) Upon execution of the first contract(s) the Department shouid commence the design of the FIS facilities on the basis of the contractual commitments that then exist for fis services. These facilities should have the capacity for storage of only that amount of spent fuel which is committed to storage under the then-existing contracts.

(5) These first contract(s) should detemine the fee for FIS services from the schedule of fees published in the Federa? Register. The Initial Payment should be the unit price in effect for the total storage capacity required by such contract(s) or for 100 MTU, whichever is larger. This same Initial Payment should then be charged to all subsequent users of FIS services until the Initial Payment is next revised.

(7) The Department should revise its fee (both the Initia? and Final Payment) annually to reflect (among other things) the economies of a larger FIS operation which results from additional commitments for FIS services.

(8) Upon completion of the preoperational activities (i.e., design, safety reviews, construction, and associated activities), the Department should determine the total costs incurred $\cdots$ and should credit or debit the Final Payment of each user with the difference between the amounts paid as Initial payments and its pro rata share of the total preoperational costs (net of its pro rata share of interest earned on advance payments made).

(9) After decommissioning of the FIS system, or December 31, 2001, whichever is later, the Department should determine the total costs incurred in design, construction, operation and decormissioning of the FIS system through December 31, 2001 -and should make final adjustments to the extent that there is a difference between the amounts paid by each user in Initial and Final Payments and the user's pro rata share of the aforementioned costs (net of its pro rata share of interest earned on advance payments made).

The Department should plan to sign contracts for FIS services with users within 60 days after the user's need has been certified by NRC. This is necessary in order for the Department to be able to provide the required storage facilities on a timely basis. 


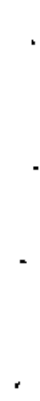


7.0 SPENT FUEL ACCEPTANCE CRITERIA FOR FIS

In developing revised spent fuel acceptance criteria, JAI continued to be mindful of the facts that FIS was intended for use only in special situations and that only a limited amount of spent fuel would be eligible for FIS. This is in marked contrast to the repository program, which can be expected to receive all spent fuel for disposal purposes, absent any reprocessing in the U.S. Therefore, in order to simplify the FIS program and minimize the costs attendant therewith, it was concluded that the interests of the prospective users of FIS services were best served by the Department accepting only non-defective fue 1 assemblies and canistered consolidated fuel rods meeting specific and clearly defined acceptance criteria.

JAI has reviewed the spent fuel acceptance criteria which was included in the 1984 report and has found no basis to make any further changes thereto at the present time. For the convenience of the reader, the acceptance criteria contained in the 1984 and 1985 reports has been included in Exhibit $C$ to this report. 


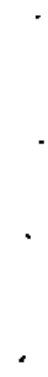


EXHIBIT A

DESIGN DESCRIPTION AND ESTIMATED COSTS FOR THE DRY STORAGE

OF SPENT NUCLEAR FUEL IN FEDERAL INTERIM STORAGE FACILITIES 
EXHIBIT A

TABLE OF CONTENTS

Page

1.0 SPENT FUEL CANISTERS Al-I

1.1 Description AI-2

1.2 Estimated Cost Al-2

2.0 RECEIVING AND HANDLING FACILITIES A2-1

2.1 Facitities for Receiving and Transfer A2-I

2.2 Facilities for Receiving, Canning and Transfer A2-7

2.3 Modification of Existing Facilities A2-8

2.4 Estimated Costs A2-10

3.0 STORAGE CASKS A3-I

3.1 Description A3-1

3.2 Estimated Cost A3-1

4.0 DRYWELLS A4-1

4.1 Description A4-1

4.2 Estimated Cost A4-1

5.0 CONCRETE SILOS A5-1

5.1 Description A5-1

5.2 Estimated Cost A5-1

6.0 STORAGE FAC!LITY COSTS A6-1

6.1 Cask Storage Facilities A6-1

6.2 Drywell Storage Facilities A6-2

6.3 Silo Storage Facilities A6-3

6.4 Estimated Costs A6-4

7.0 OPERATING COSTS FOR FIS SYSTEM A7-1

7.1 Loading, Storage and Removal A7-1

7.2 Decontamination and Decommissioning A7-4

8.0 OTHER ASSOCIATED STORAGE COSTS A8-1

8.1 Government Administrative Costs A8-1

8.2 FIS Development Costs A8-1

8.3 impact Aid A8-2

9.0 TOTAL COST OF FIS STORAGE A9-1

10.0 SENSITIVITY OF COSTS TO CHANGES IN CONOITIONS AlO-1

10.1 Impact of Cost Changes Al0-1

10.2 Impact of Schedule Changes Al0-10

10.3 Impact of Mix of Spent Fuel Types AlO-23

10.4 Impact of Discount Rate A10-28

10.5 Impact of NRC Licensing Status Al0-33 
EXHIBIT A

DESIGM DESCRIPTION AND ESTIMATED COSTS FOR THE DRY STORAGE

DF SPENT NUCLEAR FUEL IN FEDERAL INTERIM STORAGE FACILITIES

This Exhibit describes the design of the components of the alternative FIS systems considered, including (i) canisters, (ii) required new facilities for the transfer of spent fuel from shipping casks to either transfer casks or storage modules and for performing the encapsulation of spent fuel in cases where such is considered necessary, ( $i i i)$ modifications to existing facilities at government sites which are necessary to perform the same operations as described in (ii) above, (iv) storage modules, and ( $v$ ) storage facilities. The results of estimates of the capital cost of the components of the alternative FIS systems are presented as are the cost of operation thereof, and the special costs stipulated by the Act to be included in the development of charges for FIS services. A summary of the total and discounted costs of operation of the FIS system, and the unit costs resulting therefrom, is presented for each combination of storage method, capacity, and facility location which was considered (as described in Section 3.0 of the report).

In addition to the foregoing, sensitivity analyses were performed to determine the effects of changing conditions of cost, schedule, mix of fuel type, discount rate, and licensing-related activities on the unit cost for FIS.

1.0 SPENT FUEL CANISTERS

JAI considered both the need for canistering spent reactor fuel assembilies and the type of canister that should be employed. It was concluded that spent fuel assemblies that were destined for storage in sealed drywelis or silos should be encapsulated to provide a double containment for the fuel assemblies. Since the metal storage casks are designed with a double containment lid, no canistering of the fuel assemblies was considered necessary for this mode of storage. It was also concluded that a carbon steel canister with convex ends would perform satisfactorily in the dry storage environment. 


\subsection{DESCRIPTION}

The canister designed to contain one PWR or two BWR fuel assemblies has a 13-in. inside diameter and a 1/2-in. wall thickness. Canisters are prefabricated from 1/2-in. thick steel plate with a convex bottom and 1 id. The guide cages used to position the fuel within the canister are fabricated from 1/8-in. steel plate with 1/4-in. steel plate cage guides. A 1/2-in. steel plate is located at the bottom of the canister to support the cage and fuel. The mating surfaces of the lid and wall are machined for welding. Guides are weided inside the lid to assure positive alignment and to facilitate guiding the 1 id into place. A grapple pintle on the top of the lid is used to lift the lid and place it on the canister; it is also. used to apply pressure during welding to assure positive contact, and to lift the loaded canisters. A vent hole through the pintle and $l i d$ is provided to relieve any pressure build-up during girth-welding, and to permit pressure and leak testing of the loaded canister; it is seal welded upon completion of such testing. It can also be used to add an inert atmosphere to the canjster if desired for heat transfer or for additional corrosion protection. A TIG or MIG weld of the girth and the pintle seal welds is used to eliminate the need for a flux and subsequent chipping of slag, and the attendant generation of scrap.

Empty canisters and 1 ids are moved from storage into the hot cell and lifted using a magnetic grapple. The empty canisters are stored in special racks and the lids are placed on a conveyor that feeds the welding machine. The loaded and tested canisters are placed in interim storage in a small vault in new hot cell facilities or are stored in a shielded storage cask in existing hot cell facilities. The canisters are subsequently loaded into a transfer cask for transfer to drywell storage or are loaded directly into a concrete silo.

\subsection{ESTIMATED COST}

The cost of canisters for PWR and BWR fuel assemblies to be stored in drywelts or silos was estimated to average $\$ 4,541$ (1987 dollars). 
Three types of receiving and handing facilities were considered for the FIS facilities. At government facilities which have no hot cell facilities which can be used for the transfer of spent fuel from shipping casks into storage casks, such will have to be provided. In the case of drywell or silo storage, these transfer facilities will also have to be equipped for encapsulation of the fuel assemblies. (Encapsulation is not necessary for cask storage because the cask provides the desired double containment of the spent fuel.) Both the transfer-only and transfer/encapsulation facilities should be equipped with a limited amount of lag storage space.

At government facilities which have hot cell facilities which could be used for the above described purposes, some modifications and equipment additions are assumed to be necessary in order to perform the described activities.

This section describes the conceptual designs of the new transfer and transfer/encapsulation facilities, and the required additions and modifications to an existing one -- and provides an estimate of the capital costs associated with such facilities.

\subsection{FACILITIES FOR RECEIVING AND TRANSFER}

A basic design for a transfer facility was developed and is shown in Figures A2-1, A2-2 and A2-3. This facility is a simple hot-cell facility equipped with standard hot cell equipment, and is designed to accomplish the following operations:

(1) receive, inspect and washdown and/or decontaminate the shipping casks and storage casks

(2) remove the cask heads from the casks and temporarily store them

(3) remove the spent fuel from the shipping cask and place it in the storage cask

(4) place the cask head on the storage cask when loaded, seal, and transfer the cask to the storage area

(5) place the cask head on the empty shipping cask and prepare cask for return shipment 


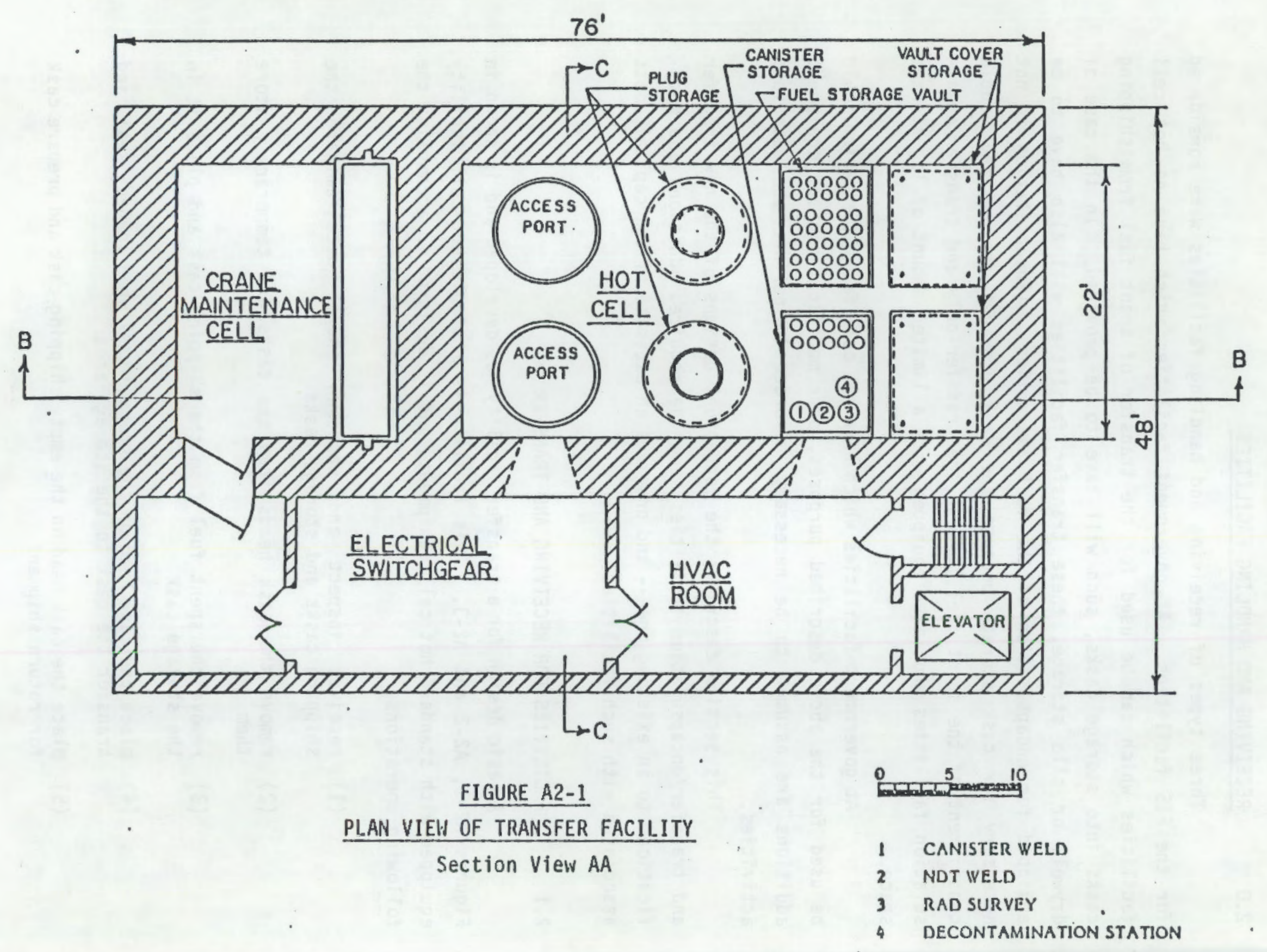





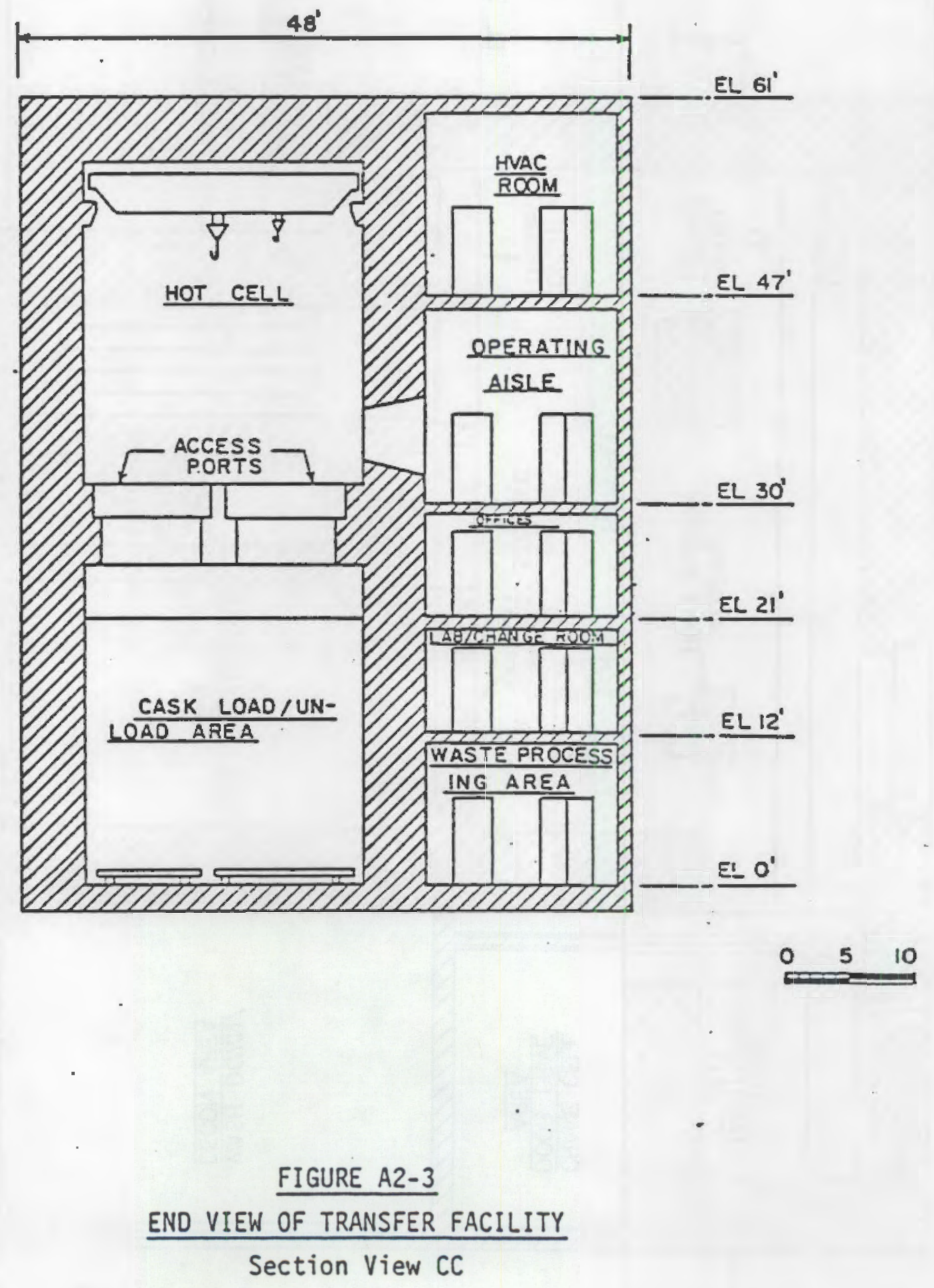


(6) provide a small amount of lag storage in the hot cell to minimize shipping cask turnaround time, and for general operational convenience.

It is recognized that there have been a number of unique conceptual designs developed for accomplishing these types of transfer operations at low estimated capital cost. However, the development of these designs has not proceeded to the point that the Department should risk the use of them from either a cost or licensing standpoint, in the establishing of charges for FIS services at the present time.

Spent fuel shipping casks are received at the FIS facility on special rail cars for the IF-300 cask and on tractor-trailer trucks for the NLI $1 / 2$ cask. The rail transport vehicle is spotted on a rail siding, extending into the concrete pad in front of the FIS transfer facility; the trucks are aiso spotted on this same pad. The mobile transporter straddles the rail car or truck and engages the trunions of the cask after the personnel barriers, tie-downs and impact 1 imiters are removed. The casks are lifted horizontally to clear the carrier vehicle and moved to a clear space on the concrete pad. The casks are then rotated to a vertical position using a small hoist. They are then positioned over the dolly and lowered onto it. Tiedowns to attach the cask to the dolly are secured and the trunions disengaged. The mobile transporter is moved into the clear to be available for other work including transport of storage casks, transfer casks or silos to the storage area. The dolly and cask is moved into the washdown/decontamination area for final inspection, removal of the outer head and inner head bolts, attachment of the inner head lifting sling and installation of the expandable seal ring, gasket protection, and contamination bib. The dolly and cask are then ready to be moved into the air lock (cask unloading) area.

The transfer facility described in Figures $A 2-1, A 2-2$ and $A 2-3$ is a reinforced concrete structure having overall dimensions of $48 \mathrm{ft} . \times 76 \mathrm{ft}$. by $61 \mathrm{ft}$. high. The interior of the hot cell is $22 \mathrm{ft}$. wide, $45 \mathrm{ft}$. long and 25 ft. high and contains a 40-ton bridge crane with a 10-ton auxiliary hoist on the same trolley. A clearance of $18 \mathrm{ft}$. under the crane hooks is provided for handling grapples and fuel assemblies. The crane is equipped with an inching motor for precise movement as well as an emergency drive to move the crane into the $22 \mathrm{ft}$. $x 13 \mathrm{ft}$. shielded maintenance cell at one end of the hot cell. 
All shielding walls are constructed of $5-\mathrm{ft}$. thick nuclear grade concrete and are lined with stainless steel plate for ease of decontamination. A $5-\mathrm{ft}$. thick concrete door can be used to shield the crane maintenance cell from the hot cell in the event spent fuel is exposed in the hot cell and a crane breakdown occurs. Cell viewing is provided through two 4-ft. square, leadglass windows and CCTV cameras on the crane and in the cell. A master slave, heavy duty manipulator at each view-window is available for special purposes.

Lag storage is available in two small vaults below the floor level of the hot cell, each with space for 35-40 baskets in safe geometry spacing. Each vault has a 5 -ft. thick concrete cover to be used in the event the hot cell needs to be entered when spent fuel is in lag storage. Each such vault is $7 \mathrm{ft}$. wide, $10 \mathrm{ft}$. long and $31 \mathrm{ft}$. deep (see Figure A2-2). Cooling is provided by drawing cell ventilation air through the fuel assemblies into a plenum in the lower part of each vault. The air is filtered and cooled in the HVAC area.

The cask loading/unloading area is an air-lock $22 \mathrm{ft}$. wide and $21 \mathrm{ft}$. long where both the shipping casks and storage casks are brought in on dollies and raised to mate with the underside of the hot cell access port for unloading and loading. An expandable seal between the top of the cask and the access port prevents cell atmosphere leakage into the air-lock area.

The two cell plugs which fill the access port between the air-lock and the hot cell are each constructed with a ring and a center plug such that they can be removed either together or individually. Only the center plug is removed when a truck cask is to be unloaded while both the plug and ring are removed for rail casks and storage casks. Special storage holes are provided in the floor of the hot cell for the cell plugs when they are removed in order to permit top surfaces of the plugs to be flush with the hot-cell floor, el iminating the need for additional head room in the cell (see figure A2-2).

The auxiliary area is a multi-storied building with the HVAC and electrical switch gear equipment located on the top floor (see Figures A2-1 and $A 2-3)$. The second floor is used as an operating aisle and a manipulator repair shop. The bottom floor is utilized for low-level liquid and solid waste handling and processing, including catch tanks for the hot cell and decontamination areas, liquid filter and ion exchange systems, liquid waste solidification equipment and solid waste compaction equipment. 
The other floors of the auxiliary area are utilized for change room facilities, health physics analytical laboratory, general plant maintenance shop, and administrative and engineering offices.

FACILITIES FOR RECEIVING, CANNING AND TRANSFER

The same basic facilities that were described for the transfer of spent fuel from shipping casks to storage casks in Section 2.1 can be used for the receipt, canning and transfer of the canned spent fuel assemblies to either silos or a transfer cask (in the cask of drywell storage). However, in the latter cases, the facilities are equipped to perform the following additional activities:

(1) load spent fuel assemblies into canisters

(2) weld lid onto canister

(3) backfill canister and seal

(4) test/inspect weld integrity, and

(5) decontaminate loaded canisters.

In these cases one of the two $7 \mathrm{ft}$. by $10 \mathrm{ft}$. by $31 \mathrm{ft}$. deep vaults shown in Figure A2-1 is utilized for new canister storage, loaded canister storage and the welding and test equipment. A special weiding jig accurately positions the canisters against guide and drive rollers. New canisters and lids are moved into the cell through the air-lock to the cell port and to the weld $j i g$ or lag storage by means of an electromagnetic grapple. After the fuel assemblies are loaded into the canister, a handling tool picks up a lid from a conveyor and places it on the canister, holding it in place during welding. The TIG welder is positioned using a roller-follower to maintain weld gap distance. The canister is rotated and the welding sequence carried out. A canister grapple lifts the canister to the test jigs for weld and leak tests and radiation survey test.

Also for these cases, a part of the first floor of the auxiliary area is used as a warehouse to store the new canisters. Part of the second floor is el iminated to provide a high-bay warehouse so the canisters can be stored vertically. A small jib crane in this area with a magnetic grapple is 
used to transfer the canisters to a handling cart for movement to the air-lock and into the cell. An $18 \mathrm{ft}$. high, double door provides access to this warehouse area.

\section{3}

MODIFICATION OF EXISTING FACILITIES

For the purposes of determining the likely cost of dry storage of spent fuel in FIS facilities at a government site which has an existing hot cell it was assumed that all of the activities described in Sections 2.1 and 2.2 could be performed in the hot cell with certain additions and modifications. It was also assumed that other existing facilities were available to washdown incoming casks to remove road dirt prior. to unloading in the hot cell.

The hot cell was assumed to be $50 \mathrm{ft}$. wide, $160 \mathrm{ft}$. 1ong and $55 \mathrm{ft}$. high. It is equipped with a 150/15-ton crane (15-ton auxiliary hoist on same trolley) with a hook height of $50 \mathrm{ft}$. It has a bridge mounted, overhead heavy duty manipulator with an elbow capacity of 5000 pounds, a manipulator capacity of 600 pounds, and a hook height of $28 \mathrm{ft}$. In addition the cell is equipped with two wall-mounted manipulators with a $28 \mathrm{ft}$. reach and a $27 \mathrm{ft}$. hook height. The cell is shielded with $7-\mathrm{ft}$. thick, reinforced concrete and has lead-glass viewing windows at two operating elevations on both sides of the cell length. The manipulators could be used in the welding operation but the hook height is insufficient for lifting spent fuel or loaded canisters to or from casks. The hot cell is supported by HVAC equipment, radiation alams, laboratories for checking activity levels of smear samples, and radwaste processing facilities to handle decontamination solutions.

Any existing special test equipment in the hot cell would need to be removed or stored out of the way and the hot cell totally dedicated to the receiving, canning, and/or transfer of spent reactor fuel during the period that fuel is received for storage, and when it is being removed from storage. The modifications assumed to be required include the following:

(1) installation of CCTV on the cranes, overhead manipulators and in the cell to provide close-up viewing of operations

(2) construction of cask support structures in the cell to prevent the casks from falling from the vertical position during operations 
(3) procurement and installation of a modified metal storage cask for lag storage of loaded canisters prior to their placement in drywells or silos, and of two standard storage casks for lag storage of spent fuel unloaded from shipping casks (since radioactive material contained in the cell will need to be enciosed in shielded containers prior to introducing or removing items from the cell)

(4) construction of racks for all cask heads including those from storage casks that will need to be used for lag storage

(5) installation of welding and testing equipment described in Section 2.2 for the canistering of spent fuel assemblies

(6) installation of a conveyor for canister lids and a rack for new canisters.

It was assumed the cell cranes and manipulators are usable without modification.

The handling procedure at the existing hot cell was assumed to differ from a new FIS transfer facility. The vehicles (trucks) bringing the casks to the existing hot cell are assumed to move directly into and out of the cell through shielded, air-lock doors. The cask tie-downs, personne? barriers, and impact limiters are removed. The trunions are engaged with a yoke using the 150-ton bridge crane. The cask is lifted clear of the vehicle and rotated to a vertical position. It is then moved to a special cask holder where it is locked in place to prevent tipping during unloading or from any seismic activity. This holder aiso serves as a scaffold for worker access to the top of the cask to remove head boits and attach head lifting slings. The outer head is removed and stored and the inner head bolts removed. Metal storage casks are placed in similar cask holders with their inner heads in place to shield any fuel assemblies transferred previously. The operators vacate the cell and the cell door is closed so that remote unloading can be conducted. The inner heads of the transport and storage casks are removed and the fuei is transferred from the shipping cask to the storage cask. Where fuel is to be sealed in canisters, three metal storage casks are used for surge storage; one for PWR fuel, one for BWR fuel and one for canistered assemblies. When canisters are to be moved to silos or drywells, a mobile transporter is used to bring the silo or transfer cask into the cell for loading. 
It was also assumed for the purposes of this study that a separate storage area would be provided for the storage of modules at a government site having existing transfer facilities.

\subsection{ESTIMATED COSTS}

Estimates were made of the capital costs of new transfer and encapsulation facilities required for the FIS of spent fuel at a government site having no such facilities. A summary of these estimated costs is set forth in Table A2-1 for each of the three methods of dry storage considered.

TABLE A2-1

ESTIMATED CAPITAL COSTS OF NEW TRANSFER AND ENCAPSULATION FACILITIES

$(\$ 000,1987)$

Site Preparation

Structures

Equipment

Equipment Installation

( $35 \%$ of equipment cost)

Engineering (15\%)

Licensing

Contingency (35\%)

Total
Capital Costs

\begin{tabular}{|c|c|c|}
\hline $\begin{array}{c}\text { Storage } \\
\text { Cask } \\
\end{array}$ & Drywell & silo \\
\hline 12 & 12 & 12 \\
\hline 6,781 & 6,781 & 6,781 \\
\hline 3,703 & 4,485 & 4,490 \\
\hline 1,296 & 1,570 & 1,572 \\
\hline 11,792 & 12,848 & 12,855 \\
\hline 1,769 & 1,927 & 1,928 \\
\hline 872 & 872 & 872 \\
\hline 14,433 & 15,647 & 15,655 \\
\hline 5,052 & 5,476 & 5,479 \\
\hline$\$ 19,485$ & $\$ 21,123$ & $\$ 21,134$ \\
\hline
\end{tabular}


Estimates were also made of the cost of additions and modifications to the existing hot cell which are required to transfer and encapsulate spent fuel. A summary of these estimated costs is set forth in Table A2-2 for each of the three methods of dry storage considered.

\section{TABLE A2-2}

ESTIMATED COSTS OF ADDITIONS AND MODIFICATIONS TO AN EXISTING HOT CELL FOR TRANSFER AND ENCAPSULATION OF SPENT FUEL $(\$ 000,1987)$

\begin{tabular}{|c|c|c|c|}
\hline \multirow[b]{3}{*}{ Equipment } & \multicolumn{3}{|c|}{ Capital Costs } \\
\hline & $\begin{array}{c}\text { Storage } \\
\text { Cask } \\
\end{array}$ & \multirow{2}{*}{$\frac{\text { Drywell }}{\$ 5,095}$} & \multirow{2}{*}{$\frac{\mathrm{si10}}{\$ 5,098}$} \\
\hline & $\$ 945$ & & \\
\hline \multirow[t]{2}{*}{$\begin{array}{l}\text { Equipment Installation } \\
\text { (35\% of equipment cost) }\end{array}$} & 331 & $494^{a}$ & $495^{\mathrm{a}}$ \\
\hline & 1,276 & 5,589 & 5,593 \\
\hline Engineering (15\%) & 191 & 838 & 839 \\
\hline \multirow[t]{2}{*}{ Safety Review } & 398 & 398 & 398 \\
\hline & 1,865 & 6,825 & 6,830 \\
\hline Contingency (35\%) & 653 & 2,389 & 2,391 \\
\hline Total & 2,518 & $\$ 9,214$ & $\$ 9,221$ \\
\hline
\end{tabular}

$\bar{a}$ assumes no installation cost for metal storage casks used for lag storage 



\subsection{STORAGE CASKS}

\subsection{DESCRIPTION}

The use of metal storage casks, which may or may not be licensed for transportation over the road, for the storage of spent fuel offer an attractive option in common with the drywell and silo modes, in that it permits the addition of storage capacity in small increments as increased capacity is required. The casks offer an additional advantage of providing capability for on-site transportation of spent fuel with the possible future prospect of serving as off-site shipping containers.

At the present time, several cask manufactures have metal storage cask designs; Ridihalgh, Eggers and Associates, Inc. (the REA-2023 cask)*, Transnuclear, Inc. (the TN-24 cask), GNS (the CASTOR-V cask), Nuclear Assurance Corporation, and Westinghouse. For this study, the Transnuclear, Inc. TN-24 cask was selected, as it represents the capacity and cost typical of these large storage casks. The TN-24 cask is shown in Figure A3-1. The cask weight (loaded) is 100 U.S. tons; it is $16 \frac{1}{2} \mathrm{ft}$. in length and $8 \mathrm{ft}$. in diameter. It will store either 24 PWR or 52 BWR fuel assemblies. According to design data, the cask will limit the fuel clad temperature to $375^{\circ} \mathrm{C}$, at a decay heat of $1.0 \mathrm{~kW} / \mathrm{PWR}$ assembly (24 kW total).

It is assumed that each cask can be procured with a mounting skid that can be moved with the cask onto a storage area pad, el iminating the need for special cradles.

\subsection{ESTIMATED COST}

Based upon manufacturers estimates and assuming delivery to a Western U.S. site, the 1987 cost of the metal storage cask was estimated to be $\$ 1,147,380$.

*This cask design is now owned by Mitsubishi. 


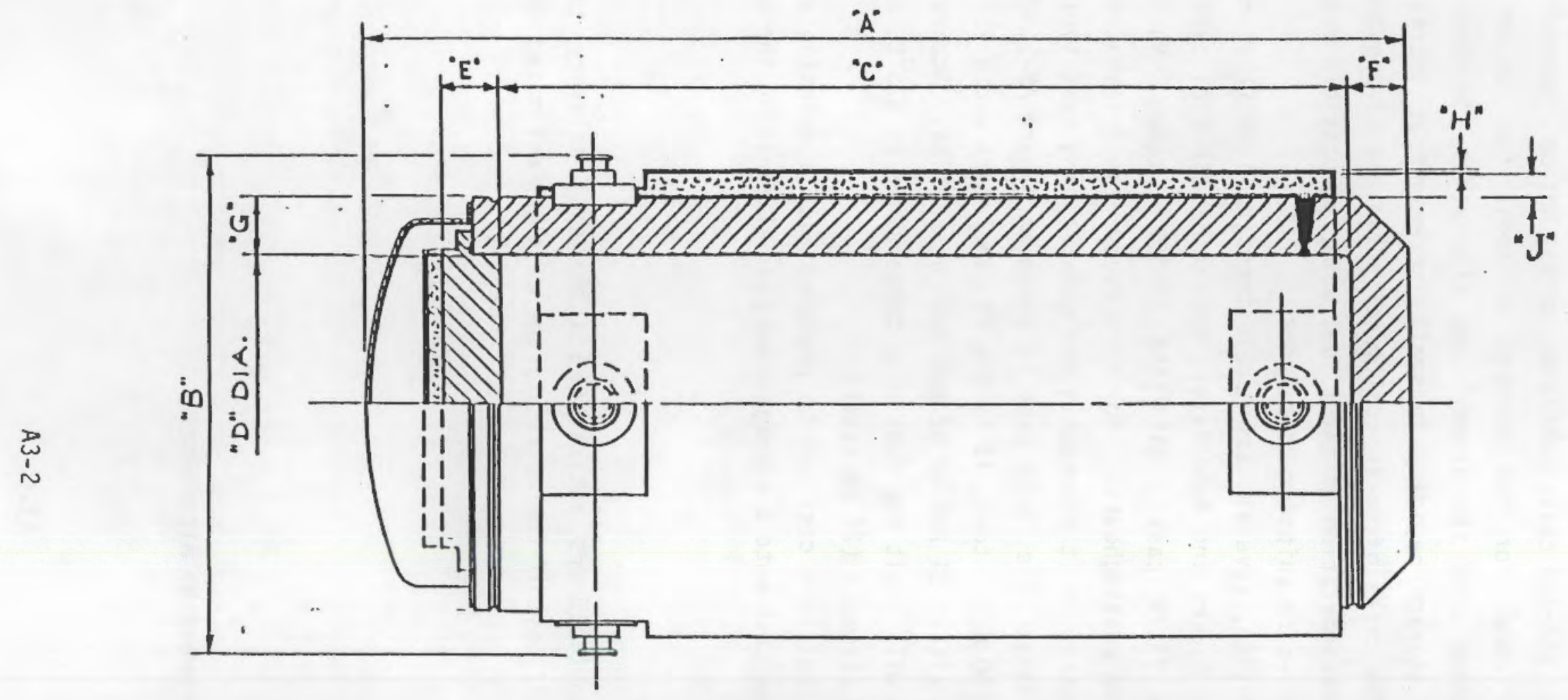
A. Length 5030 mun
B. Diameter $2400 \mathrm{~mm}$
D. Cavity Diameter $1460 \mathrm{~mm}$
E. Lid Thickness $270 \mathrm{~mm}$
G. Wall Thickness $240 \mathrm{~mm}$
C. Cavity Length $4140 \mathrm{~mm}$
F. Bottom Thickness $260 \mathrm{~mm}$
H. Shell Thickness $20 \mathrm{~mm}$
J. Shield Thickness $140 \mathrm{~mm}$

FIGURE A3-1

TN-24 CASK FOR SPENT FUEL STORAGE 


\subsection{DRYWELLS \\ 4.1 DESCRIPTION}

Storage of spent fuel in drywells just below grade is an alternative method of interim storage. The drywells are placed on a grid within a fenced storage area. Each drywell, when loaded and the liner welded closed, provides a sealed, secondary containment for canistered spent fuel assemblies.

A schematic drawing of the drywell design used in this study is set forth in Figure A4-1. The drywell liner consists of a schedule 40 steel pipe which is $16 \mathrm{ft} ., 6 \mathrm{in}$. long and has an outside diameter of $16 \mathrm{in}$. A 1/2-in. thick plate is welded into the base of the pipe to form the bottom of the iner. A 1/2-in. thick transition ring is welded to the top of the 16 in. liner. The base of a concentric $5 \mathrm{ft}$. long, schedule 40 steel pipe, with a 20in. outside diameter is then welded to the transition ring. The top of the 20-in. diameter pipe is machined to permit a seal plate of $1 / 2-i n$. thick steel to be inserted in a recess for welding. The transition ring provides a ledge to support the $48-i n$. long concrete shield plug. The liner is surrounded by 3 in. of grout on the sides and an 8-in. grout plug underneath. A 5-ft. diameter concrete collar, $20 \mathrm{in}$. thick surrounds the top of the liner and is tapered to $2 \mathrm{in}$. above grade level at the drywell liner to assure positive drainage of any surface water. A 1/2-in. thick steel cover is welded to the top of the liner after a canister of fuel is loaded therein and the concrete plug is in place. Each drywell will contain one canister of spent fuel. The top of the active fuel rods is $8-10 \mathrm{ft}$. below grade level with the canister in place. The surrounding earth serves as a radiation barrier as well as conductor of heat from the drywell.

\subsection{ESTIMATED COST}

The cost of the drywells described in Section 4.1 was estimated to be $\$ 20,609$ (1987 dollars). Therefore, the total cost of the drywell assembly, including the canisters described in Section 1.0, is estimated to be $\$ 25,150$. 

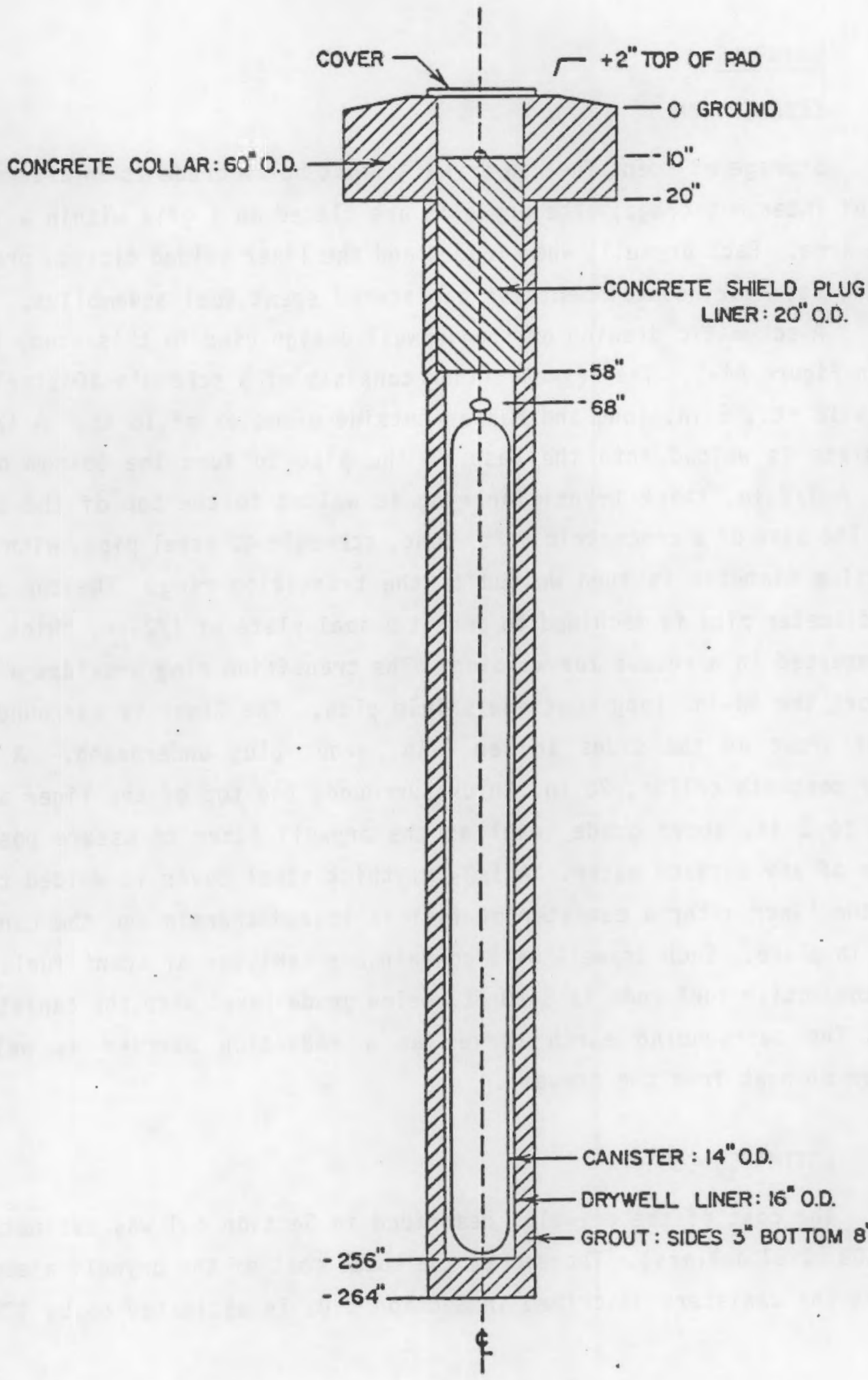

FIGURE A4-1

SCHEMATIC DIAGRAM OF DRYWELL 
5.0 CONCRETE SILOS

5.1 OESCRIPTION

Another alternative is the storage of spent fuel in concrete silos above ground. The silos are placed in rows on concrete stands within a fenced storage area. Each silo, when loaded and the liner welded closed, provides a sealed secondary containment for canistered spent fuel assemblies.

A schematic drawing of the silo design developed in this study is shown in Figure A5-1. A silo is a reinforced concrete structure $10 \mathrm{ft}$. in diameter and $23 \mathrm{ft}$. high. It has an inside cavity which is $45 \mathrm{in}$. in diameter and is lined with 1/4-in. steel that also serves as an inside form for pouring the structure. A 2-ft. high pedestal is located in the center of the cavity to support a secondary containment liner. This liner is $36 \mathrm{in.}$. in diameter (outside) and has a 1/2-in. wall thickness. The bottom segment of the liner is $17 \mathrm{ft}$. long; at the top it is welded to the upper segment which is $39-i n$. diameter (inside) and $3 \mathrm{ft}$. long. The upper segment of the liner passes through the upper cavity of the silo structure and receives a 4-ft. long concrete plug to effect the closure of the liner cavity. After loading of the silo with canisters of spent fuel and insertion of the plug in the upper segment of the liner, a steel $l$ id is welded on the top of the upper liner cavity to effect the double containment of the fuel. A cruciform spacer is provided for the lower 1 iner cavity to position the canisters of spent fuel contained within. Each silo is capable of storing 4 canisters of spent fuel (4 PNR assemblies or 8 BWR assemblies). The loaded silo weighs about 125 tons.

\subsection{ESTIMATED COST}

The cost of the silos described in Section 5.1 was estimated to be $\$ 97,729$ (1987 dollars). Therefore, the total cost of the silo assembly, including four of the canisters described in Section 1.0, is estimated to be $\$ 115,893$. 


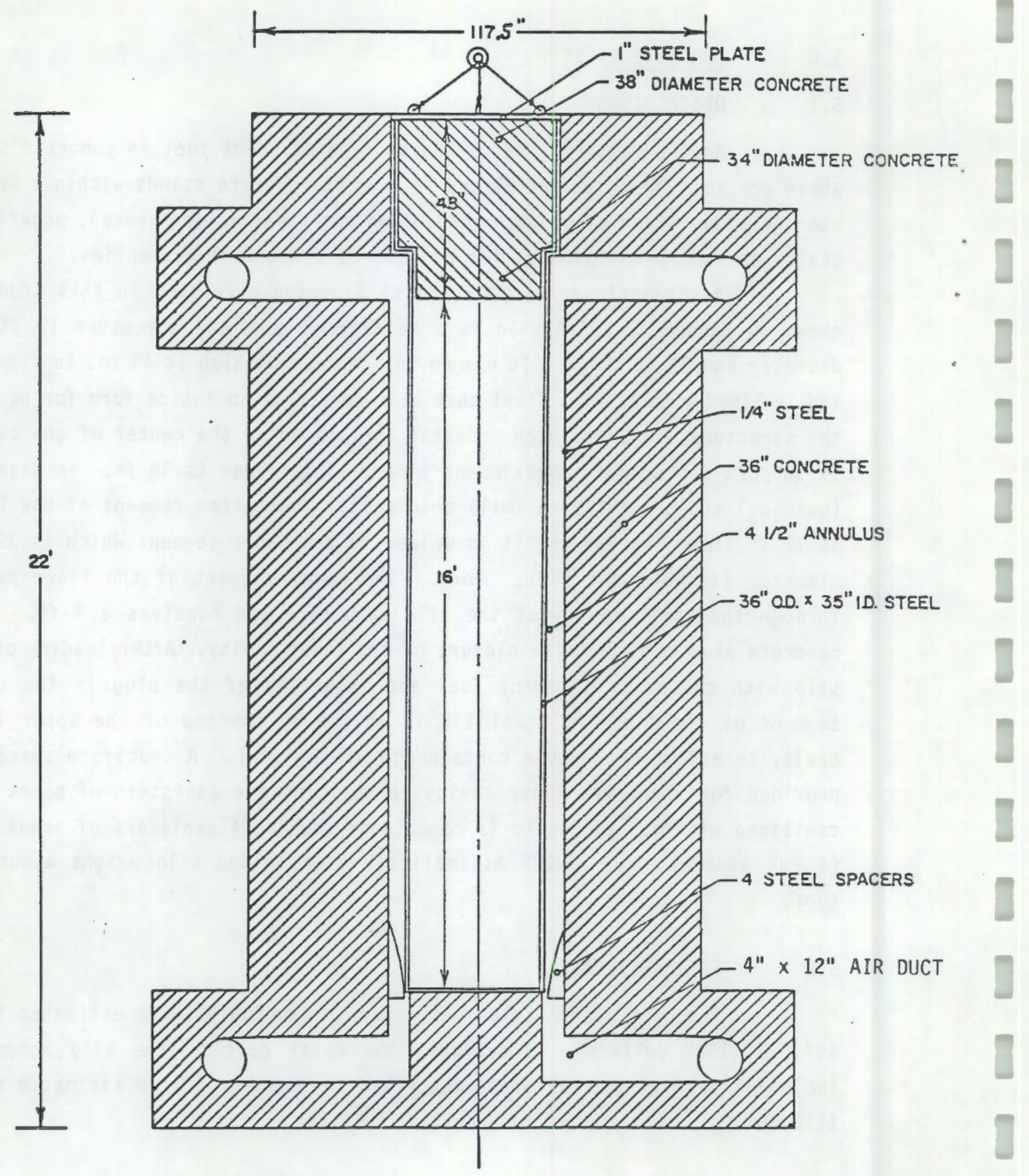




\subsection{STORAGE FACILITY COSTS \\ 6.1 CASK STORAGE FACILITIES}

The storage of spent fuel in storage casks requires a storage area with concrete stands to support the casks and a transporter to move the loaded cask to the storage area. Storage stands are added as required.

The storage cask area is a graded area with concrete stands $10 \mathrm{ft}$. wide and $18 \mathrm{ft}$. long made of 18-in. thick reinforced concrete and includes a $300 \mathrm{ft}$. Iong and $30 \mathrm{ft}$. wide paved road between the transfer facility and the storage area. Casks are brought to the storage area by a transporter. The casks, on their skids, are placed end-to-end in two parallel rows on the concrete stands which are separated $10 \mathrm{ft}$. apart. On each side of each pair of rows is a $30 \mathrm{ft}$. access driveway to permit easy access to each cask in its storage location. A $50 \mathrm{ft}$. buffer zone is provided around the perimeter of the concrete pad and is surrounded by an $8 \mathrm{ft}$. high chain link security fence topped with 3 strands of barbed wire. The bottom of the fence is anchored in concrete. A microwave security system is used to monitor the perimeter of the storage area, and the area is lighted. A security gate permits access of the transporter and inspection personnel to the storage area.

The transporter used to move the storage casks from the transfer facility to the storage area consists of a commercially available straddle crane having a 150-ton lift capacity, which is modified by the addition of a strongback and yoke. The cask is first lifted from the receiving carrier in a horizontal position and rotated to the vertical. After loading the cask with spent fuel and sealing the heads, it is lifted by the transporter, rotated to horizontal, and placed on its skid. After securing the cask to its skid, the cask/skid unit is lifted and moved to the storage area. When fully loaded, the speed of the transporter is limited to $60-100 \mathrm{ft}$. per minute. The straddie crane is mounted on dual rubber tires on all four corners and is driven by a diesel engine. It can operate on both gravel and paved roads, and can negotiate grades up to $6 \%$. It has the capability of making a $90^{\circ}$ turn. The whee base, tread width and clear height are easily modified from standard equipment sizes by removing or adding structural sections to customize the unit to handle the storage casks. 


\subsection{DRYWELL STORAGE FACILITIES}

The storage of canistered spent fuel in drywells requires a storage area, drywells, and handling equipment to transfer canisters to the drywells. This equipment includes a top loading/bottom discharge transfer cask, a plug cask, a shielded seal valve, transport vehicles, a portable welder for sealing each drywell, and a 1/2-ton hydraulic hoist to $1 \mathrm{ift}$ and move the drywell cover. Drywells are added as required.

The drywell storage area is a graded area with 6 in. of compacted gravel between the drywells which are constructed on approximately $19 \mathrm{ft}$. centers. The storage area is connected to the transfer facility by a $300 \mathrm{ft}$. long and $30 \mathrm{ft}$. wide paved road. A $50 \mathrm{ft}$. buffer zone is provided around the perimeter of the storage area and is surrounded by an $8 \mathrm{ft}$. high chain link security fence topped by 3 strands of barbed wire. The bottom of the fence is anchored in concrete. A microwave security system is used to monitor the perimeter of the storage area, and the area is lighted. A security gate permits access of the transporters and inspection personnel to the storage area.

The canisters of spent fuel are moved to the storage area in a transfer cask. This cask is a modified NFS-4 type cask with the length extended to accommodate the 188-in. long canisters and equipped with a shielded, manually operated valve on the bottom end with a mating surface to fit into the shield valve at the drywell. The top of the cask has an easily removable head with an integral electrically operated winch to raise and lower the canisters. The transfer cask head is brought into the hot cell, positioned over the canister storage rack, and canister is grappled and lifted by the winch up to the head. The canister and head are lowered by the cell crane into the cask until the cask head mates with the cask. The head is clamped or bolted in place and the transfer cask is picked up vertically by the transporter, moved to a designated drywell, and mated with the shield valve.

Both the valve in the bottom of the transfer cask and the shield valve are opened and the spent fuel canister is lowered into the drywell. After the retraction of the cable, both of the valves are closed and the transfer cask is returned to the transfer facility. A smaller cask containing the drywell plug is then positioned over the shield valve and mated. Both the 
valve in the bottom of the plug cask and the shield valve are then opened and the plug is lowered into the top of the drywell cavity. After retraction of the cable, the plug cask and the shield vaive are lifted together and moved to the next empty drywell position. The cable from the plug cask is lowered to engage the pintie on the piug and the plug is withdrawn into the plug cask. Both the valve on the bottom of the piug cask and the shield vaive are then closed and the plug cask is removed. The above process is then repeated.

After loading of each drywell, a steel cover is placed on the top of the drywell and is welded to the top of the drywelt liner.

Two transporters are used to move the transfer casks and the plug cask/shield valve. Both consist of commercially available straddle cranes having a 60-ton $1 \mathrm{fft}$, and which are modified with a special strongback. The speed of these transporters is 1 imited to $130 \mathrm{ft}$. per minute. The straddle crane is mounted on single rubber tires on all four corners and is driven by a gasoline engine. It can operate on both gravel and paved roads and can negotiate grades up to $6 \%$. It has the capability of making a $90^{\circ}$ turn.

\subsection{SILO STORAGE FACILITIES}

The storage of canistered spent fuel in concrete silos requires a storage area with concrete stands to support the silos and a transporter to move the loaded silo from the transfer facility to a storage pad. Storage stands are added as required.

The silo storage area is a graded area with 6 in. of compacted gravel between the reinforced concrete silo storage stands. Each storage stand is a 16-in. thick, reinforced concrete slab $16 \mathrm{ft}$. wide by $32 \mathrm{ft}$. long which provides storage space for 2 silos. The stands are spaced $10 \mathrm{ft}$. apart in rows with a $25 \mathrm{ft}$. spacing (roadway) between each row of stands. The storage area is connected to the transfer facjlity by a $300 \mathrm{ft}$. Iong and 30 $\mathrm{ft}$. wide paved road. A $50 \mathrm{ft}$. buffer zone is provided around the perimeter of the storage area and is surrounded by a $8 \mathrm{ft}$. high chain link security fence topped with 3 strands of barbed wire. The bottom of the fence is anchored in concrete. A microwave security system is used to monitor the perimeter of the storage area and the area is lighted. A security gate permits access of the transporter and inspection personnel to the storage area. A transporter similar to that described for cask storage is used to transport the loaded silos from the transfer facility to the concrete stands in the storage area. 
6.4 ESTIMATED COSTS

Estimates were made of the capital cost of the storage area facilities required for the six levels of capacity considered for each dry storage method addressed in this study. A listing of these costs is set forth in Table A6-1 for government facilities which have existing transfer facilities and for those without such facilities. 
TABLE A6-1

ESTIMATED INITIAL CAPITAL COSTS FOR STORAGE AREA FACILITIES

$(\$ 000,1987)$

Storage Method

\begin{tabular}{|c|c|c|c|c|c|c|}
\hline \multirow[b]{3}{*}{ Capacity } & \multicolumn{6}{|c|}{ Storage Method } \\
\hline & \multicolumn{2}{|c|}{ Storage Cask } & \multicolumn{2}{|c|}{ Drywell } & \multicolumn{2}{|c|}{ Silo } \\
\hline & $\begin{array}{c}\text { At Site } \\
\text { With Existing } \\
\text { Transfer } \\
\text { Facilittes } \\
\end{array}$ & $\begin{array}{c}\text { At Site With } \\
\text { No Existing } \\
\text { Transfer } \\
\text { Facilities }\end{array}$ & $\begin{array}{c}\text { At Site } \\
\text { With Existing } \\
\text { Transfer } \\
\text { Facilities } \\
\end{array}$ & $\begin{array}{c}\text { At Site with } \\
\text { No Existing } \\
\text { Transfer } \\
\text { Facilities }\end{array}$ & $\begin{array}{c}\text { At Site } \\
\text { With Existing } \\
\text { Transfer } \\
\text { Facilities } \\
\end{array}$ & $\begin{array}{c}\text { At Site with } \\
\text { No Existing } \\
\text { Transfer } \\
\text { Facilities } \\
\end{array}$ \\
\hline $50 \mathrm{MTU}$ & $\$ 2,019$ & $\$ 1,824$ & $\$ 5,622$ & $\$ 5,426$ & $\$ 2,566$ & $\$ 2,370$ \\
\hline $10 \mathrm{MTU}$ & 2,054 & 1,857 & 5,755 & 5,557 & 2,732 & 2,537 \\
\hline $300 \mathrm{MTU}$ & 2,161 & 1,964 & 6,182 & 5,987 & 3,336 & 3,140 \\
\hline $800 \mathrm{MTU}$ & 2,385 & 2,188 & 7,104 & 6,906 & 4,720 & 4,523 \\
\hline $1500 \mathrm{MTU}$ & 2,677 & 2,482 & 8,289 & 8,094 & 6,575 & 6,379 \\
\hline $1900 \mathrm{MTU}$ & 2,838 & 2,643 & 8,946 & 8,749 & 7,619 & 7,423 \\
\hline
\end{tabular}

$\overline{{ }^{\text {Storage }}}$ area facilities at a site with existing transfer facilities include a security guard house; in the case of a new transfer facility the guard house was included in the cost of the transfer facility. 
- 


\subsection{OPERATING COSTS FOR FIS SYSTEM}

7.1 LOADING, STORAGE AND REMOVAL

Estimates were made of the cost of operation of the FIS system for spent fuel storage at the six capacity levels considered for each dry storage method addressed in this study, and for both government sites which have no existing transfer facilities and those which do.

A listing of the total annual operating costs of Fis facilities during the years in which spent fuel is being loaded into or removed therefrom is set forth in Table A7-1 for each of the cases studied. A listing of the total annual operating costs during the years in which storage-only takes place is set forth in Table $A 7-2$ for each of the cases studied. 
TABLE A7-1

ESTIMATEO ANNUAL OPERATING COSTS FOR TRANSFER FACILITIES AND STORAGE FACILITIES

DURING LOADING ANO REMOVAL OPERATIONS

$(\$ 000,1987)$

Storage Method

\begin{tabular}{|c|c|c|c|c|c|}
\hline \multicolumn{2}{|c|}{ Storage Cask } & \multicolumn{2}{|c|}{ Drywell } & \multicolumn{2}{|c|}{ silo } \\
\hline $\begin{array}{c}\text { At Site } \\
\text { ith Existing } \\
\text { Transfer } \\
\text { Facilities } \\
\end{array}$ & $\begin{array}{l}\text { At Site With } \\
\text { No Existing } \\
\text { Transfer } \\
\text { Facilities }\end{array}$ & $\begin{array}{c}\text { At Site } \\
\text { With Existing } \\
\text { Transfer } \\
\text { Facilities }\end{array}$ & $\begin{array}{c}\text { At Site With } \\
\text { No Existing } \\
\text { Transfer } \\
\text { Facilities }\end{array}$ & $\begin{array}{c}\text { At Site } \\
\text { With Existing } \\
\text { Transfer } \\
\text { Facilities }\end{array}$ & $\begin{array}{c}\text { At Site With } \\
\text { No Existing } \\
\text { Transfer } \\
\text { Facilities } \\
\end{array}$ \\
\hline$\$ 1,797$ & $\$ 1,885$ & $\$ 1 ; 970$ & $\$ 2,029$ & $\$ 1,878$ & $\$ 1,939$ \\
\hline 1,872 & 1,960 & 2,099 & 2,159 & 1,992 & 2,052 \\
\hline 2,162 & 2,248 & 2,617 & 2,677 & 2,338 & 2,399 \\
\hline 3,004 & 3,091 & 4,030 & 4,089 & 3,567 & 3,628 \\
\hline 4,290 & 4,376 & 6,162 & 6,220 & 4,921 & 4,982 \\
\hline 5,022 & 5,108 & 7,380 & 7,438 & 5,691 & 5,752 \\
\hline
\end{tabular}


TABLE $A 7-2$

ESTIMATED ANNUAL OPERATING COSTS FOR STORAGE FACILITIES

AT GOVERNMENT SITE DURING STORAGE ONLY PERIOD

$(\$ 000,1987)$

Storage Method

\begin{tabular}{|c|c|c|c|c|c|c|}
\hline \multirow[b]{2}{*}{ Capacity } & \multicolumn{2}{|c|}{ Storage Cask } & \multicolumn{2}{|c|}{ Drywell } & \multicolumn{2}{|c|}{ Silo } \\
\hline & $\begin{array}{c}\text { At Site } \\
\text { With Existing } \\
\text { Transfer } \\
\text { Facilities }\end{array}$ & $\begin{array}{c}\text { At Site With } \\
\text { No Existing } \\
\text { Transfer } \\
\text { Facilities }\end{array}$ & $\begin{array}{c}\text { At Site } \\
\text { With Existing } \\
\text { Transfer } \\
\text { Facilities }\end{array}$ & $\begin{array}{c}\text { At Site With } \\
\text { No Existing } \\
\text { Transfer } \\
\text { Facilities }\end{array}$ & $\begin{array}{c}\text { At Site } \\
\text { With Existing } \\
\text { Transfer } \\
\text { Facilities }\end{array}$ & $\begin{array}{c}\text { At Site with } \\
\text { No Existing } \\
\text { Transfer } \\
\text { Facilities }\end{array}$ \\
\hline 50 MTU & $\$ 966$ & $\$ 1,838$ & $\$ 1,118$ & $\$ 1,902$ & $\$ 1,056$ & $\$ 1,856$ \\
\hline $100 \mathrm{HTU}$ & 998 & 1,868 & 1,136 & 1,921 & 1,079 & 1,876 \\
\hline $800 \mathrm{MTU}$ & 1,425 & 2,399 & 1,382 & 2,184 & 1,358 & 2,392 \\
\hline $1500 \mathrm{MTU}$ & 1,857 & 3,083 & 1.663 & 2,816 & 1,636 & 2,818 \\
\hline 1900 MTU & 2,102 & 3,475 & 1,823 & 3,176 & 1,795 & 3,065 \\
\hline
\end{tabular}


7.2 DECONTAMINATION AND DECOMMISSIONING

In addition to the operating costs 1 isted in Tables $A 7-1$ and $A 7-2$ for the various methods of storage considered, the cost of decontamination and decomissioning of the storage facilities at the end of their useful iffe was estimated. These costs were assumed to amount to 20 percent of the capital cost of transfer facilities, storage area facilities and storage modules. In the case of storage at a government site which has existing transfer facilities, only the capital cost of additions and modifications to the facilities were included in the calculation inasmuch as it was reasoned that the existing facilities would otherwise have had to be decomissioned by the government in the absence of the FIS system. 
8.0 OTHER ASSOCIATED STORAGE COSTS

8.1 GOVERNMENT AOMINSTRATIVE COSTS

An estimated allowance for government administrative costs associated with the FIS program was developed which assumed that the Department's administration of the program would be handled by a Program Manager assisted to the extent necessary by another program person, an accountant, and a clerical person. The following Table A8-1 sets forth the total estimated annual costs for this administrative activity including storage fund management.

TABLE A8-1

ESTIMATED ANNUAL COSTS FOR GOVERNMENT ADMINISTRATION ASSOCIATED

WITH FEDERAL INTERIM STORAGE

$(\$ 000,1987)$

Total Capacity of FIS Facilities

\begin{tabular}{llllll}
\hline 50 & 100 & 300 & 800 & 1,500 & 1,900 \\
MTU & MTU & $\underline{\text { MTU }}$ & MTU & MTU & MTU \\
$\$ 128$ & $\$ 217$ & $\$ 335$ & $\$ 531$ & $\$ 745$ & $\$ 849$
\end{tabular}

\subsection{FIS DEVELDPMENT COSTS}

The Act provides that the Department may establish a research and development program for the dry storage of up to 300 MTU of spent fuel at facilities owned by the government (Sec. $218(\mathrm{c})$ ), that the total contributions from Federal funds shall not exceed 25 percent of the program costs (Sec. 218(d)), and that the remaining costs of such program shall be paid for by the utilities involved or shall be provided from the interim storage fund (Sec. 218(d)). For the purposes of this study, it has been assumed that all of the costs in excess of the contribution of 25 percent of the program costs from Federal funds will be borne by the utility involved in the research and development program and, therefore, none of the costs associated with the program will be included in the fee for FIS. 
However, the Act provides that funds required for the development of FIS facilities may be obtained from the storage fund (Sec. 136(d)(1)) and, therefore, will have to be included in the calculation of the fee for FIS in order to allow the Department to realize recovery of costs incurred in connection with FIS activities, as provided in Sec. 136(f)(6) of the Act. It is estimated that the costs associated with the development of the FIS program will amount to about $\$ 3.6-\mathrm{mill}$ ion and will be incurred in accordance with the following estimated schedule of expenditures:

Year

1985

1986

1987

1988

Tota 1
Amount

$(\$ 000,1987)$

$\$ 594$

1,188

1,188

594 (half year)

$\$ 3,564$

\subsection{IMPACT AID}

The cost of impact aid was estimated on the following basis:

(1) Impact aid will commence at the beginning of CY-1987 and will be teminated at the end of $C Y-2001$.

(2) The total impact aid will amount to the lesser of the foilowing alternatives:

(a) 10\% of the total cost of establishing and operating the FIS system -. including all capital, operating and decommissioning costs of the storage facilities involved, plus a pro rata share of research and development, government administration and trust fund management, but will exclude the cost of shipping.

(b) $\$ 15 / \mathrm{kgU}$ contained in the spent fuel stored.

(3) One-third of the total impact aid has been included in the Initial payment, and two-thirds $o^{*}$ the impact aid has been included in the Final Payment. 
9.0 TOTAL COST OF FIS STORAGE

The total cost associated with Fis storage was computed for each combination of storage method, capacity and location which was studied using the applicable elements of cost developed in Sections 1.0 through 8.0 of this Exhibit A, and an estimated annual spending schedule (in 1987 dollars) was developed for each such case. The annual costs which were estimated to be incurred prior to the startup of the FIS system plus the annual costs of the storage modules required (the component to be included in the Initial payment) and the annual costs which were estimated to be incurred after startup through decommissioning (the component to be included in the final Payment) were separately discounted to 1987 at a discount rate of $2 \% /$ year.

The Initial payments were calculated by equating the total discounted costs estimated to be incurred prior to startup of the FIS system and the discounted revenues (which are equal to the discounted quantities times a uniform unit cost) and solving the equality for the unknown value, i.e., the unit cost. Since the Initial Payment is assumed to be made in 1987 for all spent fuel to be stored, the revenues would be as follows:

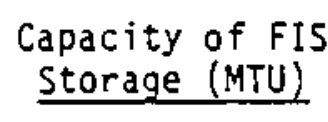

50

100

300

800

1500

1900

\section{Revenues}

$50 \mathrm{p}$
$100 \mathrm{p}$
$300 \mathrm{p} 1$
$800 \mathrm{p}$
$1,500 \mathrm{p}_{1}$
$1,900 \mathrm{p}_{1}$

where $P_{1}$ is the unit cost (or initial Payment)

The Final Payments were similarly calculated using the discounted total costs estimated to be incurred after startup of the FIS system and the discounted revenues set forth in Table A9-1.

The estimated spending schedules, discounted annual costs and the calculation of the Initial and Final Payments for FIS of spent fuel for each of the cases studied are set forth in Tables A9-2 through A9-37. 
IABLE A9-1

ANMUAL AND DISCOUHIEO REVEMUES RECEIYED FROW FIMAL PAYMEMIS FOR FIS SERYICES

\begin{tabular}{|c|c|c|c|c|c|c|c|c|c|c|c|c|}
\hline \multirow[b]{3}{*}{ Year } & \multicolumn{12}{|c|}{ Capacity } \\
\hline & \multicolumn{2}{|c|}{$50 \mathrm{MrU}$} & \multicolumn{2}{|c|}{$100 \mathrm{MTU}$} & \multicolumn{2}{|c|}{$300 \mathrm{MTU}$} & \multicolumn{2}{|c|}{$000 \mathrm{KTU}$} & \multicolumn{2}{|c|}{$1500 \mathrm{MTU}$} & \multicolumn{2}{|c|}{$1900 \mathrm{NTU}$} \\
\hline & Rev. & $\begin{array}{l}01 s c \\
\text { To } 1987 \\
0 \quad 2 \underline{y r}\end{array}$ & Rey. & $\begin{array}{l}015 c \\
\text { Ta 1987 } \\
28 / Y r\end{array}$ & Rev. & $\begin{array}{l}\text { 0isc. } \\
\text { To } 1987 \\
\text { 2r/Yr }\end{array}$ & Rev: & $\begin{array}{l}\text { D1sc. } \\
\text { To } 1987 \\
2 \leq / Y r\end{array}$ & Rev. & $\begin{array}{l}\text { D1sc. } \\
\text { To } 1987 \\
\text { 2 } 2 / 4 \mathrm{r}\end{array}$ & Rey. & $\begin{array}{l}\text { ofsc } \\
\text { To } 1987 \\
\text { 2\%/Yr }\end{array}$ \\
\hline 1990 & $\$ B P_{2}$ & $\$ 7.5 \mathrm{P}_{2}$ & $117 \mathrm{P}_{2}$ & $\$ 16.0 \mathrm{P}_{2}$ & $550 P_{2}$ & $\$ 47.1 \mathrm{P}_{2}$ & $\$ 133 P_{2}$ & $\$ 125.3 \mathrm{P}_{2}$ & $1250 P_{2}$ & $\$ 235.6 P_{2}$ & $1317 P_{2}$ & 1298.7 \\
\hline 1991 & $\$ 17 \mathrm{P}_{2}$ & $15.7 \mathrm{P}_{2}$ & $33 P_{2}$ & $30.5 \mathrm{P}_{2}$ & $100 P_{2}$ & $92.4 P_{2}$ & $267 P_{2}$ & $246.7 \mathrm{P}_{2}$ & $500 P_{2}$ & $461.9 P_{2}$ & $633 P_{2}$ & 584.8 \\
\hline 1992 & $17 P_{2}$ & $15.4 P_{2}$ & $33 \mathbf{P}_{2}$ & $29.9 P_{2}$ & $100 P_{2}$ & $90.6 P_{2}$ & $267 P_{2}$ & $241.8 P_{2}$ & $500 P_{2}$ & $452.9 P_{2}$ & $633 P_{2}$ & 573.3 \\
\hline 1993 & ${ }^{B} \mathrm{P}_{2}$ & $? .1 \mathrm{P}_{2}$ & $17^{9}$ & $15.1 P_{2}$ & ${ }_{50} P_{2}$ & $44.4 P_{2}$ & $133 P_{2}$ & $118.1 P_{2}$ & $250 P_{2}$ & $222: 0 P_{2}$ & ${ }_{317} P_{2}$ & 281.5 \\
\hline Total & $\stackrel{\$ 50}{=} \mathrm{P}_{2}$ & $145.7 \mathrm{P}_{\hat{Z}}$ & $\underline{10 n} P_{\bar{Z}}$ & $991.5 P_{2}$ & 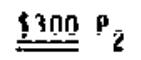 & $2 ? M^{4}{ }^{5} P_{\bar{Z}}$ & $\underline{1800} P_{\overline{2}}$ & $273 ! .99 P_{2}$ & $11500 P_{2}$ & $113724 P_{2}$ & $\underline{1900} P_{2}$ & $2173 \mathrm{~g} .3$ \\
\hline
\end{tabular}

\footnotetext{
assumes revenues recelved in first three years after startup on a uniform basis
} $\mathrm{P}_{2}$ - Final Payment 
TABLE A9-2

ESTIMATED SPENDINE SCHEDULE FOR STQRAGE OF 5 CASKS (SO MTU)

AT GOVERINHENT SITE WITHOUT EXISTING FACILITIES

$(9000,1987)$

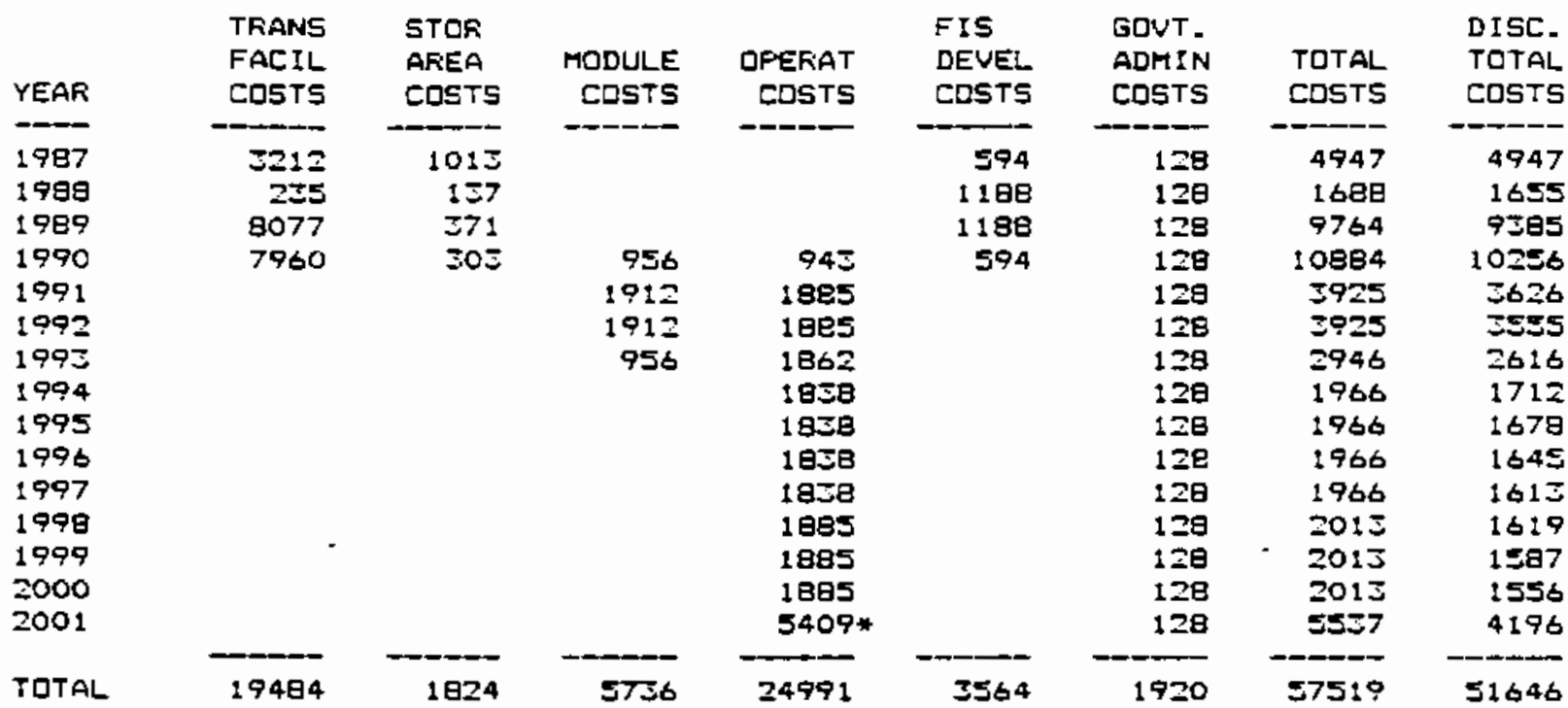

* - Decomaissioning cast

Initial Payment $=598 \mathrm{~s} / \mathrm{KgU}$ (Includes $\mathbf{5} / \mathrm{Kgl}$ impact aid)

Final Payment $=491$ t/Kgl (Includes $x: 0 / \mathrm{Kgl}$ impact aids)

TABLE A9-3

ESTIMATED SPENDING SCHEDULE FOR STDRAGE DF 10 CASKS (100 MTU) AT GDVERNIENT SITE WITHDUT EXISTING FACILITIES $(\$ 000,1 \% 97)$

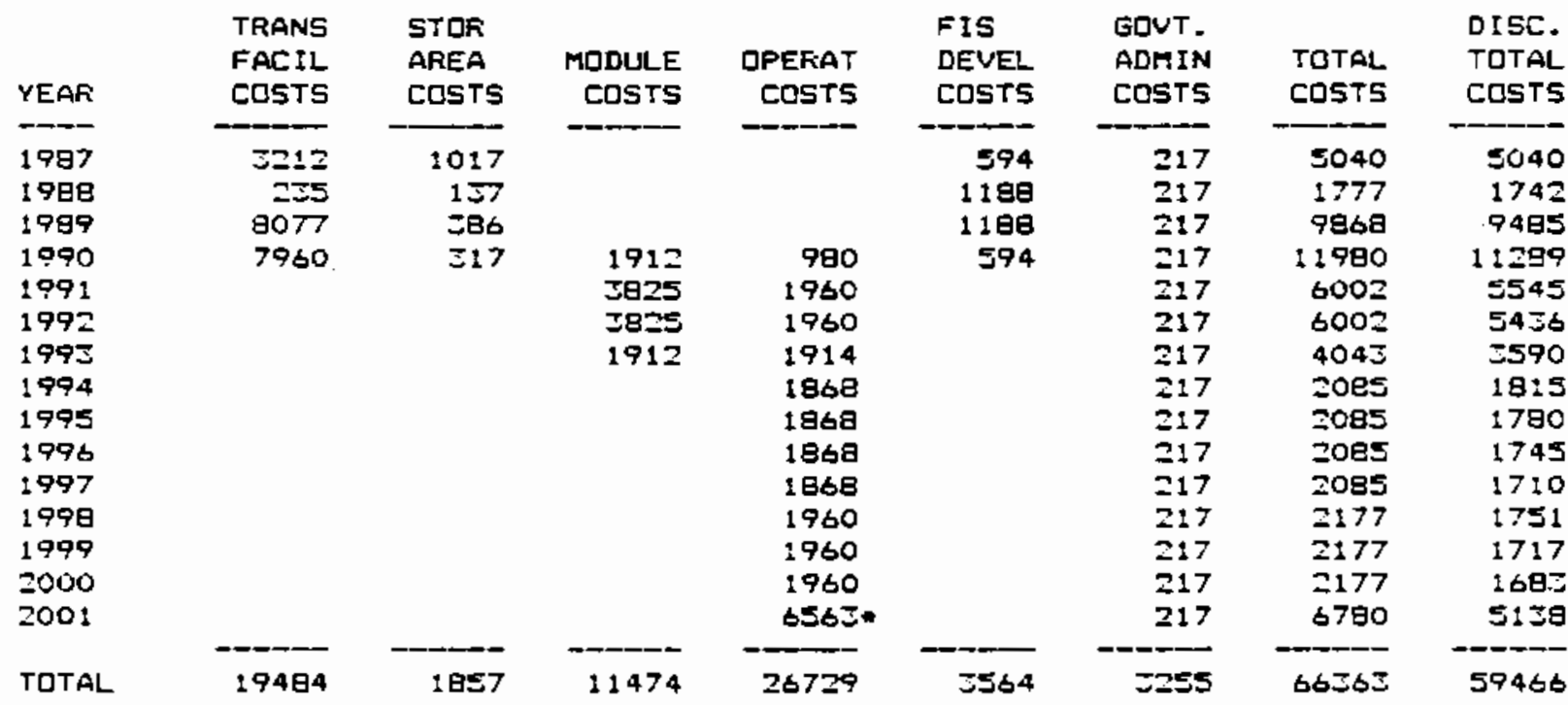

* - Decommissioning sast

\footnotetext{
Initial Payment $=357 \% / \mathrm{Kg}$ (Includes $15 / \mathrm{KgU}$ impast aid)

Final Fayment $=275 * / \mathrm{kg}$ (Includes $\$ 10 / \mathrm{kg}$ ( impact aid)
} 
TABLE A9-4

ESTIMATED SFENDING SCHEDULE FOF STORAGE OF 29 CASKS (300 MTU) AT GOVERNMENT SITE WITHOUT EXISTING FACILITIES

$(5000,1987)$

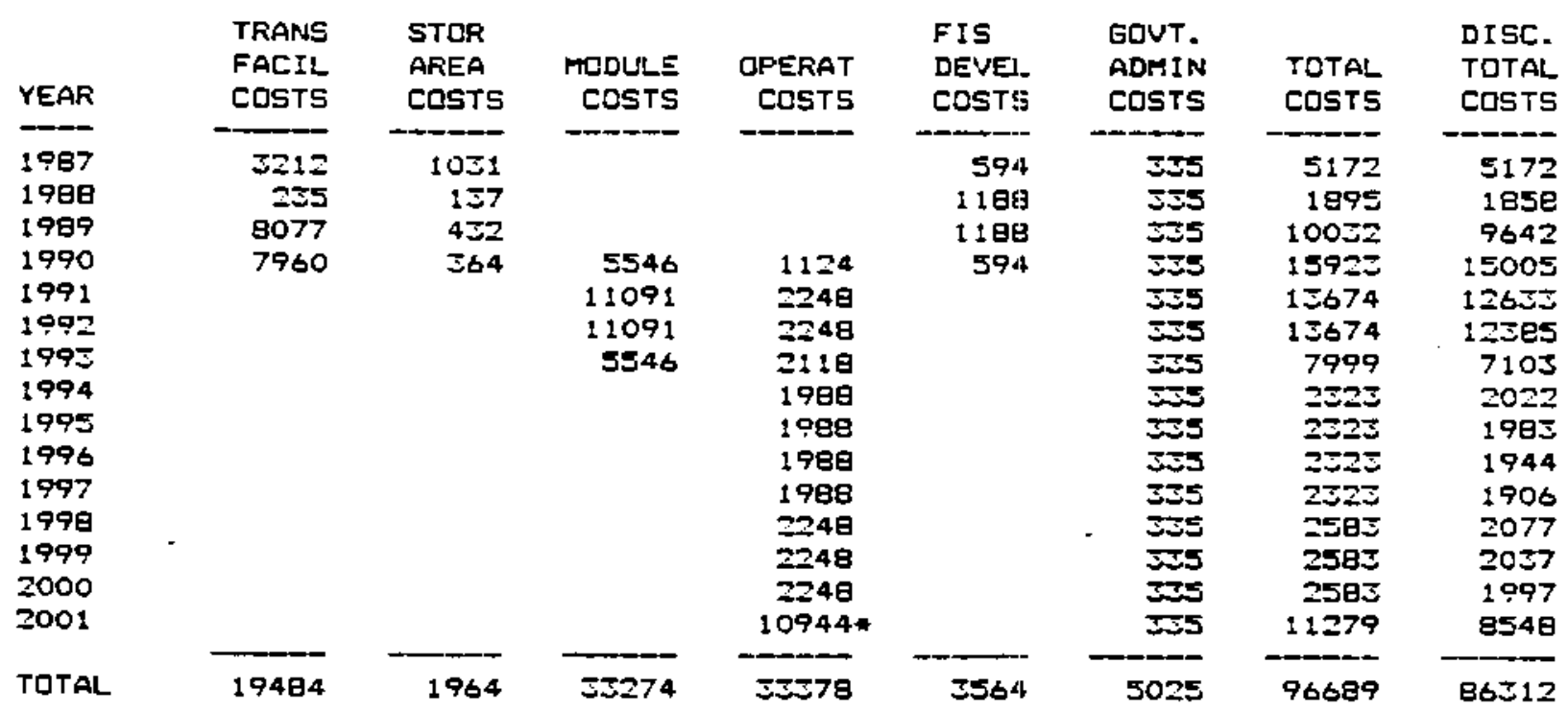

* - Decommissioning cost

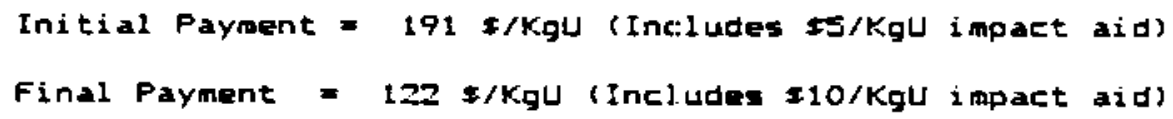

TABLE A9-5

ESTIMATED SPENDING SCHEDULE FDR STORAGE OF 76 CASKS (BOO MTU) AT GOVERNMENT SITE WITHOUT EXISTING FACILITIES

$(\$ 000,1987)$

\begin{tabular}{|c|c|c|c|c|c|c|c|c|}
\hline YEAR & $\begin{array}{l}\text { TRANS } \\
\text { FACIL } \\
\text { COSTS }\end{array}$ & $\begin{array}{l}\text { STOR } \\
\text { AREA } \\
\text { COSTS }\end{array}$ & $\begin{array}{r}\text { MODULE } \\
\text { COSTS }\end{array}$ & $\begin{array}{r}\text { OFERAT } \\
\text { COSTS }\end{array}$ & $\begin{array}{l}\text { FIS } \\
\text { DEVEL } \\
\text { CQSTS }\end{array}$ & $\begin{array}{l}\text { GOVT. } \\
\text { ADMIN } \\
\text { COSTS }\end{array}$ & $\begin{array}{l}\text { TOTAL } \\
\text { COSTS }\end{array}$ & $\begin{array}{l}\text { DISC. } \\
\text { TOTAL } \\
\text { COSTS }\end{array}$ \\
\hline $\begin{array}{l}1997 \\
1998 \\
1989 \\
1990 \\
1991 \\
1992 \\
1993 \\
1994 \\
1995 \\
1996 \\
1997 \\
1998 \\
1999 \\
2000 \\
2001\end{array}$ & $\begin{array}{r}3212 \\
355 \\
8077 \\
7940\end{array}$ & $\begin{array}{r}1061 \\
137 \\
530 \\
462\end{array}$ & $\begin{array}{l}14535 \\
29067 \\
29067 \\
14553\end{array}$ & $\begin{array}{l}1546 \\
3091 \\
3091 \\
2745 \\
2399 \\
2399 \\
2399 \\
2399 \\
3091 \\
3091 \\
3091 \\
21775 *\end{array}$ & $\begin{array}{r}594 \\
1188 \\
1198 \\
594\end{array}$ & $\begin{array}{l}531 \\
5 \pm 1 \\
5=1 \\
551 \\
531 \\
5 \pm 1 \\
531 \\
551 \\
5 \pm 1 \\
551 \\
5 \pm 1 \\
551 \\
551 \\
551 \\
5 \pm 1\end{array}$ & $\begin{array}{r}3390 \\
2091 \\
10326 \\
25626 \\
32809 \\
32689 \\
17909 \\
2930 \\
2930 \\
2930 \\
2930 \\
3622 \\
3622 \\
3622 \\
22306\end{array}$ & $\begin{array}{r}5398 \\
2050 \\
9925 \\
24148 \\
30200 \\
29607 \\
15814 \\
2551 \\
2501 \\
2452 \\
2404 \\
2913 \\
2956 \\
2900 \\
16905\end{array}$ \\
\hline TOTAL & 19484 & 2190 & $B 7=00$ & $51: 17$ & 356.4 & 7965 & 171520 & 152524 \\
\hline
\end{tabular}

* - Decommissigning cost

Initial Payment $=1 \$ 7,5 / k g U$ (Iniludes $15 / k g$ limpact aid)

Final Fayment $=74 \mathrm{~s} / \mathrm{Kg}$ (Inclides $510 / \mathrm{Kg}$ (Impact aid) 
TABLE A9-6

ESTIMATED SPENDING SCHEDULE FOR STORAGE OF 143 CASKS (15OO MTU) AT GOVERNIENT SITE WITHOUT EXISTING FACILITIES

(\$000, 1987)

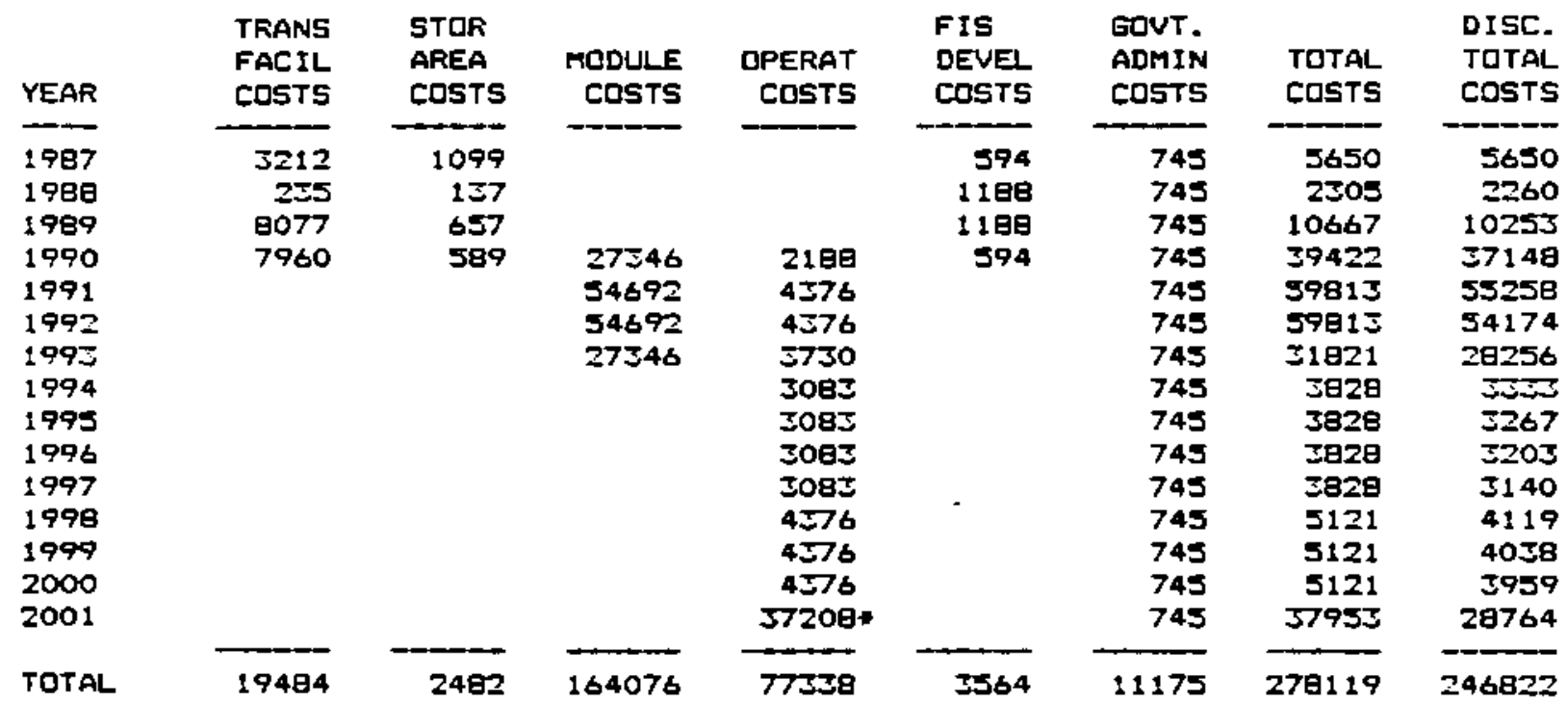

- - Decomaissioning cort

Initial Payment $=123 x / \mathrm{KgU}$ (Includes $55 / \mathrm{Kgl}$ impact aid)

Final Payment $=61 \% / \mathrm{Kgl}$ (Includes $\$ 10 / \mathrm{Kgl}$ impact aid)

TABLE A9-7

ESTIMATED SPENDING SCHEDULE FUR STORAGE OF 181 CASKS ( 1900 MTU) AT GOUERNMENT SITE WITHOUT EXISTING FACILITIES $(x 000,1987)$

\begin{tabular}{|c|c|c|c|c|c|c|c|c|}
\hline YEAR & $\begin{array}{l}\text { TRANS } \\
\text { FACIL } \\
\text { COST5 }\end{array}$ & $\begin{array}{l}\text { STOR } \\
\text { AREA } \\
\text { COSTS }\end{array}$ & $\begin{array}{r}\text { MODULE } \\
\text { COSTS }\end{array}$ & $\begin{array}{r}\text { DPERAT } \\
\text { COSTS }\end{array}$ & $\begin{array}{l}\text { FIS } \\
\text { DEvel } \\
\text { costs }\end{array}$ & $\begin{array}{l}\text { GUVT. } \\
\text { ADMIN } \\
\text { COSTS }\end{array}$ & $\begin{array}{l}\text { TOTAL } \\
\text { CDSTS }\end{array}$ & $\begin{array}{l}\text { D ISC. } \\
\text { TOTAL } \\
\text { COSTS }\end{array}$ \\
\hline $\begin{array}{l}1987 \\
1988 \\
1989 \\
1990 \\
1991 \\
1992 \\
1993 \\
1994 \\
1995 \\
1996 \\
1997 \\
1998 \\
1999 \\
2000 \\
2001\end{array}$ & $\begin{array}{r}3212 \\
235 \\
9077 \\
7960\end{array}$ & $\begin{array}{r}1120 \\
157 \\
727 \\
659\end{array}$ & $\begin{array}{l}54613 \\
69225 \\
69225 \\
54613\end{array}$ & $\begin{array}{l}2554 \\
5108 \\
5108 \\
4292 \\
3475 \\
5475 \\
3475 \\
3475 \\
5109 \\
5108 \\
5109 \\
45961\end{array}$ & $\begin{array}{r}594 \\
1188 \\
1189 \\
594\end{array}$ & $\begin{array}{l}849 \\
849 \\
849 \\
849 \\
849 \\
849 \\
849 \\
849 \\
849 \\
849 \\
849 \\
849 \\
849 \\
849 \\
849\end{array}$ & $\begin{array}{r}5775 \\
2409 \\
10841 \\
47229 \\
75182 \\
75182 \\
39754 \\
4524 \\
4324 \\
4524 \\
4324 \\
5957 \\
5957 \\
5957 \\
46810\end{array}$ & $\begin{array}{r}5775 \\
2367 \\
10420 \\
44505 \\
69457 \\
68095 \\
35300 \\
5764 \\
3690 \\
3618 \\
3547 \\
4791 \\
4697 \\
4605 \\
35476\end{array}$ \\
\hline TOTAL & 19484 & 2643 & 207676 & 92247 & 3564 & 12735 & 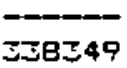 & 300102 \\
\hline
\end{tabular}

- Decammissioning cast

Initial Payment $=120 \pm / K g l$ (Includes $\$ 5 / K g U$ impact aid)

Final Payment $=57 \pm / K g L$ (Includes $5.10 / \mathrm{Kgl}$ impact aid 
TABLE A9-8

ESTIMATED SPENDING SEHEDULE FOR STCRAGE OF I IE DRYWELLS (SO MTU) AT GOVERNMENT SITE WITHDUT EXISTING F'ACILITIES

$(1000,1907)$

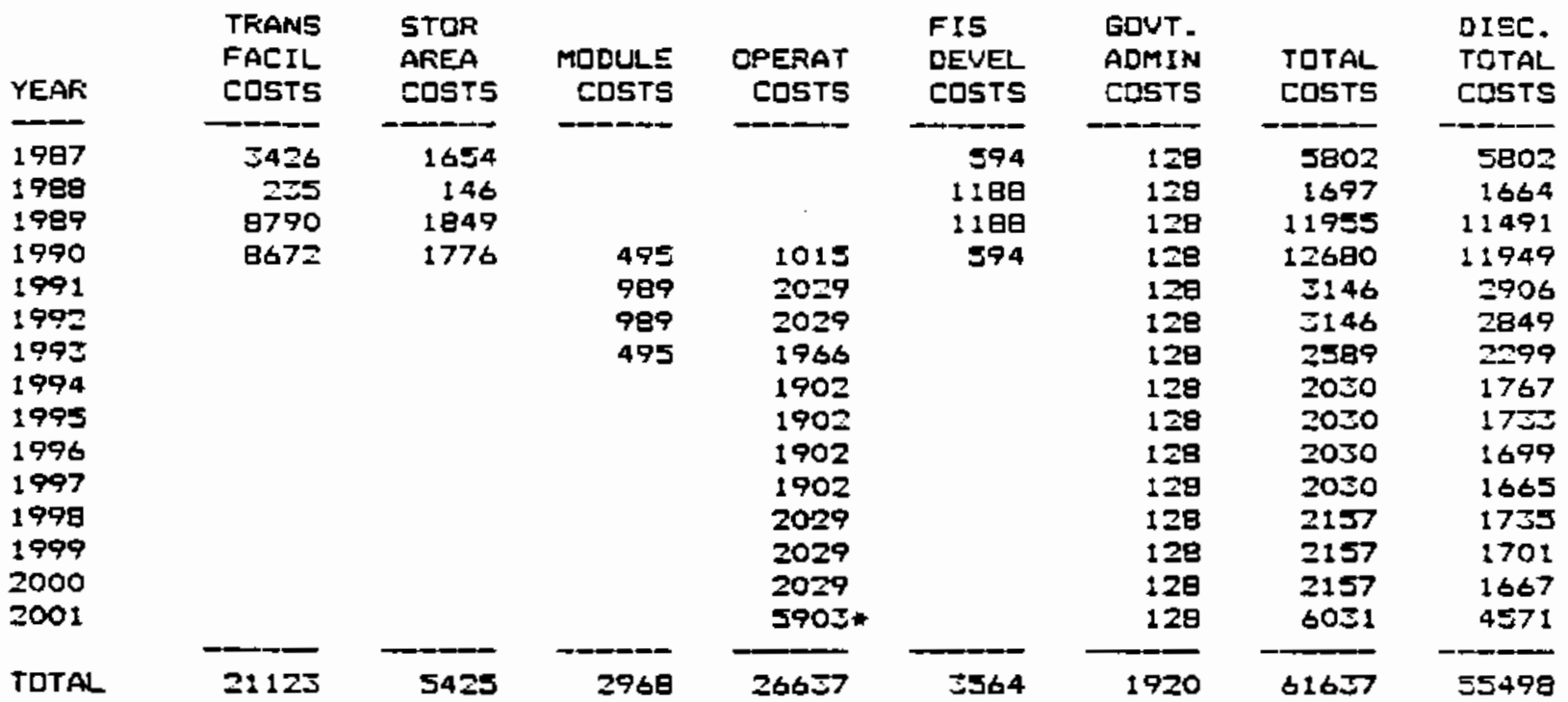

* - Decommissianing cost

Initial Payment $=646 \$ / K g L$ (Includes $53 / \mathrm{Kgl}$ impact aid)

Final Payment $=521 \neq / \mathrm{KgU}$ (Includes $510 / \mathrm{Kgl}$ impact aid)

TABLE A9-9

ESTIMATED SPENDING SCHEDULE FOR STDRAGE DF 23b DRYWELLS (100 MTU) AT GOVERNMENT SITE WITHOUT EXISTING FACILITIES

$(s 000,1987)$

\begin{tabular}{|c|c|c|c|c|c|c|c|c|}
\hline YEAR & $\begin{array}{l}\text { TRANS } \\
\text { FACIL } \\
\text { COSTS }\end{array}$ & $\begin{array}{l}\text { STDF } \\
\text { AREA } \\
\text { CDSTS }\end{array}$ & $\begin{array}{l}\text { MDDULE } \\
\text { COSTS }\end{array}$ & $\begin{array}{r}\text { DPERAT } \\
\text { COSTS }\end{array}$ & $\begin{array}{l}\text { FIS } \\
\text { DEVEL } \\
\text { CDSTS }\end{array}$ & $\begin{array}{l}\text { GOVT. } \\
\text { ADNIN } \\
\text { CDSTS }\end{array}$ & $\begin{array}{l}\text { TOTAL } \\
\text { COSTS }\end{array}$ & $\begin{array}{l}\text { DISC. } \\
\text { TQTAL } \\
\text { Cด5TS }\end{array}$ \\
\hline $\begin{array}{l}1987 \\
1988 \\
1999 \\
1990 \\
1991 \\
1992 \\
1995 \\
1994 \\
1995 \\
1996 \\
1997 \\
1998 \\
1999 \\
2000 \\
2001\end{array}$ & $\begin{array}{r}3426 \\
235 \\
9790 \\
8672\end{array}$ & $\begin{array}{r}1671 \\
146 \\
1906 \\
18=2\end{array}$ & $\begin{array}{r}999 \\
1979 \\
1979 \\
999\end{array}$ & $\begin{array}{l}1090 \\
2159 \\
2159 \\
2040 \\
1921 \\
1921 \\
1921 \\
1921 \\
2159 \\
2159 \\
2159 \\
6525\end{array}$ & $\begin{array}{r}594 \\
11 \theta 8 \\
1198 \\
594\end{array}$ & $\begin{array}{l}217 \\
217 \\
217 \\
217 \\
217 \\
217 \\
217 \\
217 \\
217 \\
217 \\
217 \\
217 \\
217 \\
217 \\
217\end{array}$ & $\begin{array}{r}5908 \\
1786 \\
12101 \\
15385 \\
4554 \\
4354 \\
5246 \\
2159 \\
2139 \\
2158 \\
2158 \\
2576 \\
2576 \\
2576 \\
6740\end{array}$ & $\begin{array}{r}5908 \\
1751 \\
11631 \\
12613 \\
4022 \\
3944 \\
2982 \\
1861 \\
1825 \\
1789 \\
1754 \\
1911 \\
1873 \\
1857 \\
5108\end{array}$ \\
\hline TDTAL & 21123 & 5556 & 5934 & 29122 & 5564 & 3255 & 67554 & 60709 \\
\hline
\end{tabular}

* - Deconnissioning cost

Initial Payment $=\Xi 59 \$ / K g$ U (Includes $\$ 5 / K g L$ impact aid)

Final Payment $=280 \pm / K g U$ (Includes $510 / K g$ limpact aid) 
TABLE A9-10

ESTIMATED SPENDING SCHEDULE FOR STORAGE DF 707 DRYWELLS ( AT GQUERNMEPTT SITE WITHOUT EXISTING FACILITIES $(\$ 000,1967)$

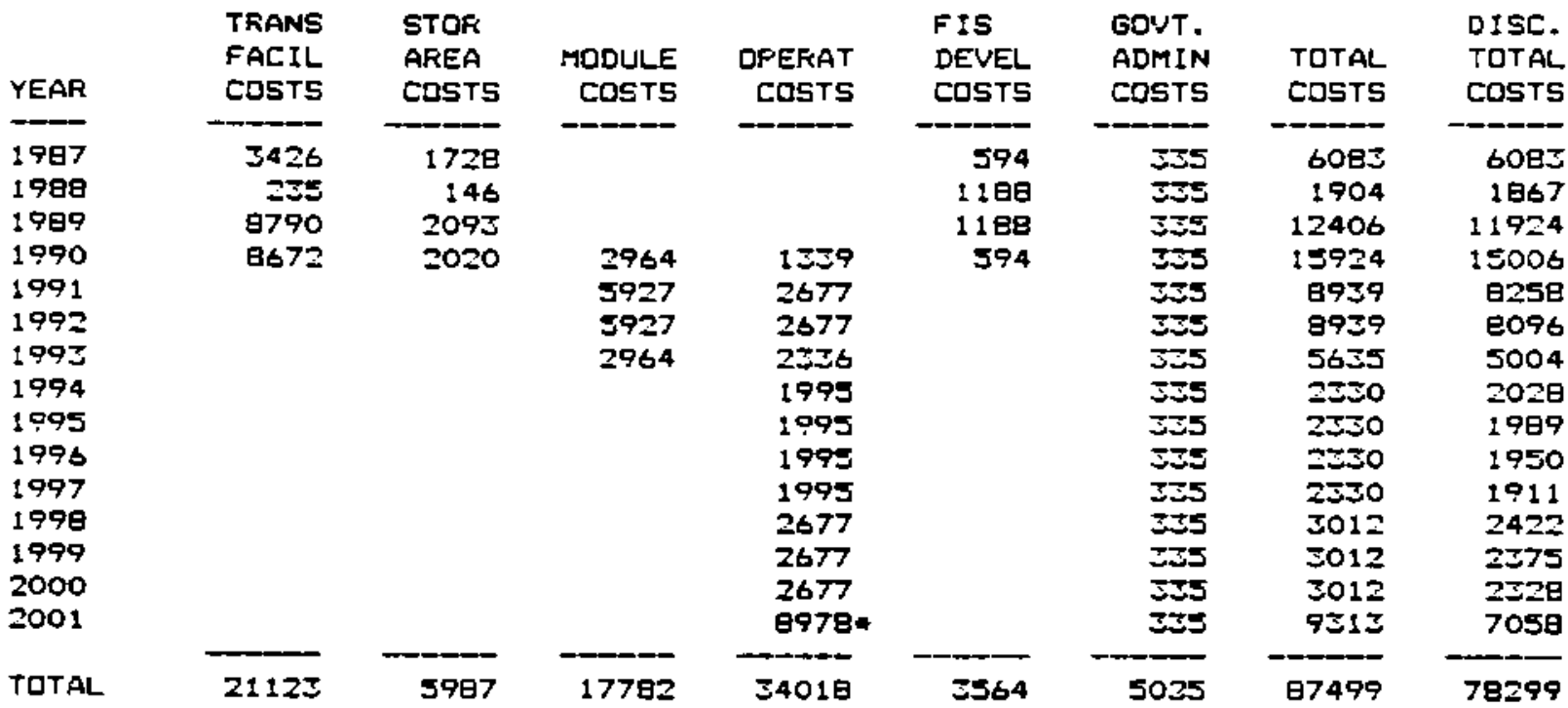

* Decomaissianing cast

Initial Payment $=161 \% / \mathrm{Kgl}$ (Includes $\$ \mathrm{~g} / \mathrm{Kgl}$ impact aid)
Final Payment $=124 \$ / \mathrm{KgU}$ (Includes $\$ 10 / \mathrm{KgU}$ impact aid)

TABLE A9-11

ESTIMATED SPENDING SCHEDLLE FOR STORAGE OF 1896 DRYWELLS (BOO MTU) AT GOVERNMENT SITE WITHOUT EXISTING FACILITIES $( \pm 000,1987)$

\begin{tabular}{|c|c|c|c|c|c|c|c|c|}
\hline YEAR & $\begin{array}{l}\text { TRANS } \\
\text { FACIL } \\
\text { CDSTS }\end{array}$ & $\begin{array}{l}\text { STOR } \\
\text { AREA } \\
\text { COSTS }\end{array}$ & $\begin{array}{r}\text { MODULE } \\
\text { COSTS }\end{array}$ & $\begin{array}{r}\text { QPERAT } \\
\text { CDSTS }\end{array}$ & $\begin{array}{l}\text { FIS } \\
\text { DEVEL } \\
\text { CDSTS }\end{array}$ & $\begin{array}{l}\text { GDVT. } \\
\text { ADMIN } \\
\text { CDSTS }\end{array}$ & $\begin{array}{l}\text { TOTAL } \\
\text { COSTS }\end{array}$ & $\begin{array}{l}\text { DISC. } \\
\text { TOTAL } \\
\text { COSTS }\end{array}$ \\
\hline 1987 & $\begin{aligned} 3426 \\
7\end{aligned}$ & 1847 & & & 594 & 531 & 6399 & 6590 \\
\hline 1980 & 235 & 146 & & & 1280 & $5 \Xi 1$ & 2100 & 2059 \\
\hline 1989 & 8790 & 2493 & & & 1198 & 531 & 13002 & 12497 \\
\hline 1990 & 9672 & 2420 & 7905 & 2045 & 594 & $\Xi \Sigma 1$ & 22167 & 2006e \\
\hline 1991 & & & 15811 & 4099 & & SI: & 20431 & 18875 \\
\hline 1992 & & & 15811 & 4089 & & 551 & $204=1$ & 1 esos \\
\hline 1993 & & & 7905 & $31 \leq 7$ & & 531 & 11573 & 10276 \\
\hline 1994 & & & & 2184 & & 521 & 2715 & 2304 \\
\hline 1995 & & & & 2184 & & $5=1$ & 2715 & 2317 \\
\hline 1996 & & & & $=184$ & & 531 & 2715 & 272 \\
\hline 1997 & & & & 2184 & & 531 & 2715 & $2 \div 27$ \\
\hline 1990 & & & & 4099 & & 531 & 4620 & 3716 \\
\hline 1999 & & & & 4089 & & $5 \equiv 1$ & $4 \$ 20$ & 3643 \\
\hline 2000 & & & & 4089 & & $\Xi \Xi 1$ & 4620 & 3571 \\
\hline 2001 & & & & 15092 & & 531 & 15623 & 11840 \\
\hline TOTAL & 21123 & 6906 & 47432 & 49455 & 3564 & 7965 & $13 \$ 445$ & 121440 \\
\hline
\end{tabular}

* - Decammissioning cost

\footnotetext{
Initial Payment $=100 \mathrm{t} / \mathrm{kgU}$ (Includes $5 / \mathrm{kg}$ (impact aid)

Final Fayment $=73 \$ / \mathrm{KgU}$ (Includes $\$ 10 / \mathrm{KgU}$ impact aid)
} 
TABLE A9-12

ESTIMATED SFENDING SCMEDULE FOR STOFAGE OF ESES DRYWELLS ( 1500 MTU) AT GOVERNMENT SITE WITHOUT EXISTING FACILITIES $( \pm 000,1987)$

\begin{tabular}{|c|c|c|c|c|c|c|c|c|}
\hline YEAR & $\begin{array}{l}\text { TRANS } \\
\text { FACIL } \\
\text { COSTS }\end{array}$ & $\begin{array}{l}\text { STOK } \\
\text { AREA } \\
\text { COSTS }\end{array}$ & $\begin{array}{r}\text { MUDULE } \\
\text { COSTS }\end{array}$ & $\begin{array}{r}\text { OPEFAT } \\
\text { COSTS }\end{array}$ & $\begin{array}{l}\text { FIS } \\
\text { DEVEL } \\
\text { COSTS }\end{array}$ & $\begin{array}{l}\text { GOUT. } \\
\text { ADMIN } \\
\text { COSTS }\end{array}$ & $\begin{array}{l}\text { TOTAL } \\
\text { COSTS }\end{array}$ & $\begin{array}{l}\text { DISC. } \\
\text { TaTAL } \\
\text { COSTS }\end{array}$ \\
\hline 1997 & 3426 & 2002 & & & 594 & 745 & 6767 & 6767 \\
\hline 1998 & 235 & 146 & & & 1168 & 745 & 2314 & 2268 \\
\hline 1989 & a790 & 5009 & & & 1180 & 745 & 13732 & 13199 \\
\hline 1990 & 8672 & 2956 & $148: 8$ & 5110 & 394 & 745 & 30975 & 29004 \\
\hline 1991 & & & 29635 & 6220 & & 745 & $\Xi 0600$ & $\Xi=01 \Xi$ \\
\hline 1992 & & & $296=5$ & $6 \geq 20$ & & 745 & 36600 & $3=150$ \\
\hline 1995 & & & 14818 & $451 \theta$ & & 745 & 20081 & $178 \Xi 1$ \\
\hline 1994 & & & & 2916 & & 745 & 3561 & $\Xi 100$ \\
\hline 1995 & & & & 2816 & & 745 & 5561 & 5039 \\
\hline 1006 & & & & 2816 & & 745 & 3561 & 2980 \\
\hline 1997 & & & & 2816 & & 745 & 5561 & 2921 \\
\hline 1998 & & & & $6 \geq 20$ & & 745 & 6965 & 5602 \\
\hline 1999 & & & & $62=0$ & & 745 & 6965 & 5492 \\
\hline 2000 & & & & $6 \geq 20$ & & 745 & 6965 & 5384 \\
\hline 2001 & & & & $23624=$ & & 745 & 24369 & 18469 \\
\hline TOTAL & 21123 & 8093 & 88906 & 73616 & 5564 & 11175 & 206477 & $19=110$ \\
\hline
\end{tabular}

- Decommissioning east

Initial Payment $=015 / \mathrm{Kg} U$ (Inclusles $54 / \mathrm{Kgl}$ impaci aid)

Final Payment $=58 * / \mathrm{KgU}$ (Ineludus $29 / \mathrm{Kgll}$ imiact aid)

TABLE A9-13

ESTIMATED SFENDING SCHEDULE FOR STORAGE OF 4478 DRYWELLS (1900 ATU) AT GONERNMENT SITE WITHOUT EXISTING FACILITIES $(\$ 000,1987)$

\begin{tabular}{|c|c|c|c|c|c|c|c|c|}
\hline YEAR & $\begin{array}{l}\text { TRANS } \\
\text { FACIL } \\
\text { COSTS }\end{array}$ & $\begin{array}{l}\text { STRK } \\
\text { AREA } \\
\text { COSTS }\end{array}$ & $\begin{array}{l}\text { MODLLE } \\
\text { COSTS }\end{array}$ & $\begin{array}{c}\text { OPERAT } \\
\text { COSTS }\end{array}$ & $\begin{array}{l}\text { FIS } \\
\text { DEVE } \\
\text { COSTS }\end{array}$ & $\begin{array}{l}\text { GOUT. } \\
\text { ADMIN } \\
\text { CDSTS }\end{array}$ & $\begin{array}{l}\text { TOTAL } \\
\text { COSTS }\end{array}$ & $\begin{array}{l}\text { DISC. } \\
\text { TOTAL } \\
\text { COSTS }\end{array}$ \\
\hline 1987 & 3426 & 2088 & & & 594 & 849 & 6957 & 6957 \\
\hline 1990 & 235 & 146 & & & 1180 & 849 & 2410 & $2 \Xi 71$ \\
\hline 1989 & 8790 & 3294 & & & 1198 & 949 & 14121 & 13573 \\
\hline 1990 & 8672 & $\Xi 221$ & 18770 & $57: 9$ & 594 & 849 & 35025 & $5 \Xi 759$ \\
\hline 1091 & & & 57541 & 7438 & & 849 & 45828 & $42=38$ \\
\hline 1992 & & & $\$ 7 \$ 41$ & 7458 & & 849 & 45828 & $4: 508$ \\
\hline 1993 & & & 18770 & $3=07$ & & 849 & 24926 & $=2134$ \\
\hline 1994 & & & & $\$ 176$ & & 849 & 4025 & 5504 \\
\hline 1995 & & & & 3176 & & 849 & 4023 & 3435 \\
\hline 1996 & & & & 5176 & & 849 & 4025 & S氵o日 \\
\hline 1997 & & & & 3176 & & 849 & 4025 & 2302 \\
\hline 1990 & & & & 7430 & & 849 & e297 & 6065 \\
\hline 1999 & & & & 7438 & & 849 & 8287 & 65.34 \\
\hline 2000 & & & & $74 \approx \mathrm{B}$ & & 849 & 8287 & 6406 \\
\hline 2001 & & & & $28499 *$ & & 849 & 20548 & $2=242$ \\
\hline TETAL & 21123 & 8749 & 112623 & 87419 & 3564 & 12735 & 246212 & 215096 \\
\hline
\end{tabular}

* - Decommissioning cast 
TABLE Ag-14

ESTIMATED SPENDING SCHEDULE FOR STORAGE OF 305 ILOS $150 \mathrm{MTU}$ ) AT GOVERNMENT SITE WITHOLT EXISTING FACILITIES $( \pm 000,1987)$

\begin{tabular}{|c|c|c|c|c|c|c|c|c|}
\hline YEAR & $\begin{array}{l}\text { TKAYS } \\
\text { FACIL } \\
\text { COSTS }\end{array}$ & $\begin{array}{l}\text { STOR } \\
\text { AREA } \\
\text { COSTS }\end{array}$ & $\begin{array}{r}\text { MODULE } \\
\text { COSTS }\end{array}$ & $\begin{array}{r}\text { OPEFAT } \\
\text { COSTS }\end{array}$ & $\begin{array}{l}\text { FIS } \\
\text { DEVEL } \\
\text { COSTS }\end{array}$ & $\begin{array}{l}\text { GOVT. } \\
\text { ADMIN } \\
\text { CDSTS }\end{array}$ & $\begin{array}{l}\text { TOTAL } \\
\text { COSTS }\end{array}$ & $\begin{array}{l}\text { DISC. } \\
\text { TUTAL } \\
\text { CASTS }\end{array}$ \\
\hline $\begin{array}{l}1987 \\
1980\end{array}$ & $\begin{array}{r}3427 \\
235\end{array}$ & $\begin{array}{r}1376 \\
146\end{array}$ & & & $\begin{array}{r}594 \\
1190\end{array}$ & $\begin{array}{l}128 \\
128\end{array}$ & $\begin{array}{l}5525 \\
1697\end{array}$ & $\begin{array}{l}5525 \\
1664\end{array}$ \\
\hline 1989 & 8795 & 461 & & & 1190 & 129 & 10572 & $1016:$ \\
\hline 1990 & B677 & इ日B & 578 & 970 & 594 & 128 & 11335 & 10681 \\
\hline 1991 & & & 1156 & 1939 & & 128 & 5223 & 2978 \\
\hline 1992 & & & 1156 & 1939 & & $12 \theta$ & sニ23 & 2919 \\
\hline 1905 & & & 579 & 1999 & & $1 \geq B$ & 2604 & 2312 \\
\hline 1994 & & & & 1956 & & 128 & 1984 & 1727 \\
\hline 1095 & & & & 1956 & & 129 & 1994 & 1693 \\
\hline 1996 & & & & 1256 & & 128 & 1984 & 1660 \\
\hline 1997 & & & & 1956 & & 129 & 1984 & 1628 \\
\hline 1998 & & & & 1939 & & 128 & 2067 & 160 ? \\
\hline 1999 & & & & 1939 & & 128 & 2067 & 1630 \\
\hline 2000 & & & & 1939 & & $12 B$ & 2067 & 1598 \\
\hline 2001 & & & & 5395* & & 128 & 5523 & 4196 \\
\hline TOTAL & $211 \equiv 4$ & 231 & 3469 & $255 B 2$ & 3564 & 1920 & 57939 & 52024 \\
\hline
\end{tabular}

* - Decommissioning cost

Initial Payment $=599 \pm / K g l$ (Includes $55 / k g$ imoact aid)

Final Payment $=499 \pm / K g U$ (Ineludes $\$ 10 / K q U$ impact aid)

IABLE A9-15

ESTIMATED SFENDING SCHEDULS FOR STIRAGE DF S9 SILUS (100 MTU) AT GUVERNITENT SITE WITHOUT EXISTING FACILITIES

$( \pm 000,1967)$

\begin{tabular}{|c|c|c|c|c|c|c|c|c|}
\hline YEAR & $\begin{array}{l}\text { TKANS } \\
\text { FACIL } \\
\text { COSTS }\end{array}$ & $\begin{array}{l}\text { STEK } \\
\text { AREA } \\
\text { CDSTS }\end{array}$ & $\begin{array}{l}\text { MODULE } \\
\text { COSTS }\end{array}$ & $\begin{array}{r}\text { OPERAT } \\
\text { COSTS }\end{array}$ & $\begin{array}{l}\text { FIS } \\
\text { DEVEL } \\
\text { CDSTS }\end{array}$ & $\begin{array}{l}\text { GDUT. } \\
\text { ADMIN } \\
\text { CDSTS }\end{array}$ & $\begin{array}{l}\text { TOTAL } \\
\text { COSTS }\end{array}$ & $\begin{array}{l}\text { DI SC. } \\
\text { TQTAL. } \\
\text { COSTS }\end{array}$ \\
\hline 1987 & 5427 & $1 \succeq 98$ & & & 594 & 217 & 5636 & 5656 \\
\hline 1989 & 235 & 146 & & & 1198 & 217 & 1796 & 1751 \\
\hline 1989 & 9795 & 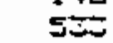 & & & 1188 & 217 & $1073 \Xi$ & 10316 \\
\hline 1990 & 0677 & 460 & 1140 & 1026 & 594 & 217 & 12114 & 11415 \\
\hline $199:$ & & & 2279 & 2052 & & 217 & 4548 & 4202 \\
\hline 1992 & & & 2779 & 2052 & & 217 & 4549 & 4119 \\
\hline 1995 & & & $1: 40$ & 1964 & & 217 & 1 & 2949 \\
\hline 1994 & & & & 1876 & & 217 & 2093 & 1922 \\
\hline 1995 & & & & 1876 & & 217 & 2093 & 1786 \\
\hline 1996 & & & & 1976 & & 217 & 2093 & 1751 \\
\hline 1997 & & & & 1878 & & 217 & 2095 & 1717 \\
\hline 1998 & & & & 2050 & & 217 & $2=67$ & 1923 \\
\hline 1999 & & & & 2050 & & 217 & 2267 & 1780 \\
\hline 2000 & & & & 2050 & & 217 & 2267 & 1752 \\
\hline 2001 & & & & 6102 * & & 217 & $6 \$ 19$ & 4789 \\
\hline TOTAL & $2: 154$ & $25=7$ & $6 E 3 \theta$ & 26850 & 3564 & 5.755 & 64178 & 57616 \\
\hline
\end{tabular}

* - Decammissianing cost

\footnotetext{
Initial Fayment $=37 t / K g U$ (Includes $55 / K g U$ impact aid)

Final Fayment $=2775 / k g U$ (Includes $\$ 10 / \mathrm{Kg}$ impact aids
} 
TABLE A9-16

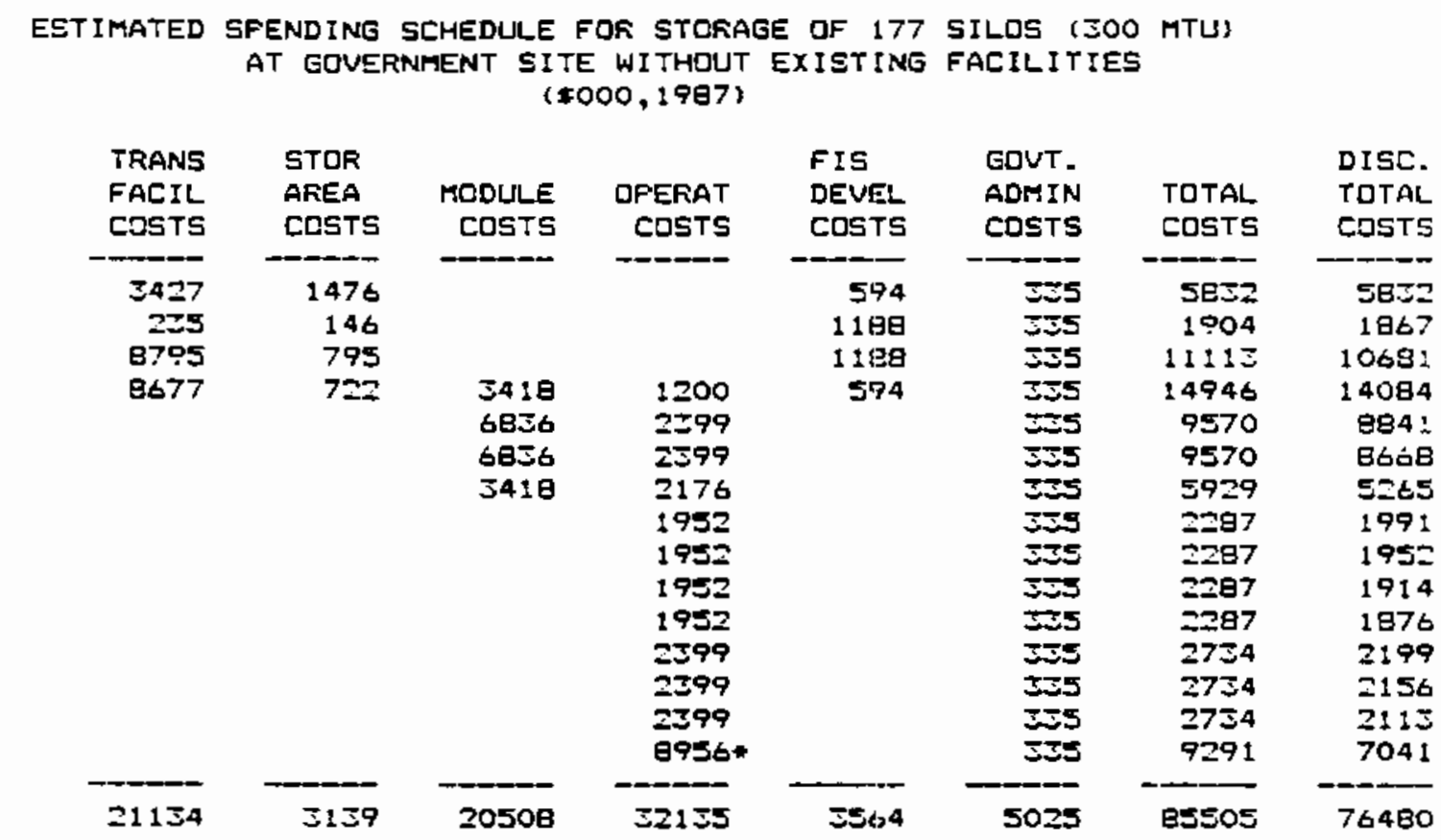

* - Decamissioning cost

Initial Payment $=1615 / \mathrm{Kgl}$ (Ineludes $55 / \mathrm{Kgl}$ impact aid)

Final Payment $=118 \$ / \mathrm{kgl}$ (Includes $710 / \mathrm{KgU}$ impact aid)

TABLE A9-17

ESTIMATED SPENDING SCHEDULE FOF STORAGE DF 471 SILOS ( 900 MTU) AT GOVERNMENT SITE WITHOUT EXISTING FACILITIES $(x 000,1967)$

\begin{tabular}{|c|c|c|c|c|c|c|c|c|}
\hline YEAR & $\begin{array}{l}\text { TRANS } \\
\text { FACIL } \\
\text { COSTS }\end{array}$ & $\begin{array}{l}\text { STDR } \\
\text { AREA } \\
\text { CDSTS }\end{array}$ & $\begin{array}{l}\text { RODULE } \\
\text { COSTS }\end{array}$ & $\begin{array}{r}\text { DFEFAT } \\
\text { COSTS }\end{array}$ & $\begin{array}{l}\text { FIS } \\
\text { DEVEL } \\
\text { COSTS }\end{array}$ & $\begin{array}{l}\text { GDVT. } \\
\text { ADHIN } \\
\text { EDSTS }\end{array}$ & $\begin{array}{l}\text { TOTAL } \\
\text { COSTS }\end{array}$ & $\begin{array}{l}\text { DISC. } \\
\text { TOTAL } \\
\text { CDSTS }\end{array}$ \\
\hline $\begin{array}{l}1997 \\
1990 \\
1999 \\
1990 \\
1991 \\
1992 \\
1993 \\
1994 \\
1995 \\
1996 \\
1997 \\
1999 \\
1999 \\
2000 \\
2001\end{array}$ & $\begin{array}{r}3427 \\
235 \\
8795 \\
9677\end{array}$ & $\begin{array}{r}1657 \\
146 \\
1597 \\
1524\end{array}$ & $\begin{array}{r}9099 \\
19199 \\
19199 \\
9099\end{array}$ & $\begin{array}{l}1914 \\
5629 \\
3628 \\
3010 \\
2392 \\
2792 \\
2392 \\
2592 \\
3629 \\
\vdots 628 \\
3629 \\
16050\end{array}$ & $\begin{array}{r}594 \\
1158 \\
1198 \\
594\end{array}$ & $\begin{array}{l}551 \\
551 \\
551 \\
531 \\
551 \\
551 \\
551 \\
551 \\
51 \\
551 \\
531 \\
51 \\
551 \\
531 \\
531\end{array}$ & $\begin{array}{r}6209 \\
2100 \\
11911 \\
22039 \\
20557 \\
22557 \\
12640 \\
2923 \\
2925 \\
2923 \\
2923 \\
4159 \\
4159 \\
4159 \\
16581\end{array}$ & $\begin{array}{r}6209 \\
2059 \\
11448 \\
20759 \\
20654 \\
20249 \\
11204 \\
=545 \\
2495 \\
2446 \\
2596 \\
5=45 \\
=579 \\
5215 \\
17566\end{array}$ \\
\hline TOTAL & 21134 & 4524 & 54594 & 48582 & $\exists E t, 4$ & 7965 & :40इ\$3 & $1=4500$ \\
\hline
\end{tabular}

* - Decommissianing cost

\footnotetext{
Initial Payment $=105 \$ / K g U$ (Iricludes $5 \$ / \mathrm{Kgl}$ impact aid)

Final Favment $=71 \pm / K g U$ (Includes $\times 10 / K$ L L impact aid)
} 
TABLE A9-18

ESTIMATED SPENOING SCHEDULE FOR STORAGE OF 984 SILOS (ISOO MTU) AT GQUERNMENT SITE WITHQUT EXISTING FACILITIES (\$000, 1987)

\begin{tabular}{|c|c|c|c|c|c|c|c|c|}
\hline YEAR & $\begin{array}{l}\text { TRANS } \\
\text { FACIL } \\
\text { COSTS }\end{array}$ & $\begin{array}{l}\text { STaR } \\
\text { AREA } \\
\text { COSTS }\end{array}$ & $\begin{array}{r}\text { MODULE } \\
\text { COSTS }\end{array}$ & $\begin{array}{r}\text { QPERAT } \\
\text { COSTS }\end{array}$ & $\begin{array}{l}\text { FIS } \\
\text { DEVEL } \\
\text { CDSTS }\end{array}$ & $\begin{array}{l}\text { GOVT. } \\
\text { ADMIN } \\
\text { COSTS }\end{array}$ & $\begin{array}{l}\text { TOTAL } \\
\text { COSTS }\end{array}$ & $\begin{array}{l}\text { DISC. } \\
\text { TOTAL } \\
\text { COSTS }\end{array}$ \\
\hline $\begin{array}{l}1987 \\
1988 \\
1999 \\
1990 \\
1991 \\
1992 \\
1997 \\
1994 \\
1995 \\
1994 \\
1997 \\
1998 \\
1999 \\
2000 \\
2001\end{array}$ & $\begin{array}{r}5427 \\
235 \\
8795 \\
9677\end{array}$ & $\begin{array}{r}1999 \\
146 \\
2203 \\
2130\end{array}$ & $\begin{array}{l}17074 \\
34140 \\
34148 \\
17074\end{array}$ & $\begin{array}{c}2491 \\
4982 \\
4982 \\
5900 \\
2919 \\
2918 \\
2918 \\
2818 \\
4992 \\
4982 \\
4992 \\
25491 .\end{array}$ & $\begin{array}{r}594 \\
1190 \\
1198 \\
594\end{array}$ & $\begin{array}{l}745 \\
745 \\
745 \\
745 \\
745 \\
745 \\
745 \\
745 \\
745 \\
745 \\
745 \\
745 \\
745 \\
745 \\
745\end{array}$ & $\begin{array}{r}6665 \\
2314 \\
12931 \\
31711 \\
39675 \\
59875 \\
21719 \\
5563 \\
5563 \\
3563 \\
3563 \\
5727 \\
5727 \\
5727 \\
25756\end{array}$ & $\begin{array}{r}6665 \\
2269 \\
12429 \\
29882 \\
36838 \\
34116 \\
18296 \\
3102 \\
3041 \\
2981 \\
2923 \\
4606 \\
4516 \\
4427 \\
20263\end{array}$ \\
\hline TOTAL & 21134 & 6378 & 102444 & 6E564 & 5364 & 11175 & 213258 & $189 \Xi 44$ \\
\hline
\end{tabular}

- Decomissioning cost

Initial Payment $=89 s / \mathrm{Kgl}$ (Includes $15 / K g U$ impact aid)

Final Payment $=35 t / \mathrm{Kg} U$ (Includes $59 / \mathrm{KgU}$ impact aid)

TABLE A9-19

ESTIMATED SPENDING SCHEDULE FOR STORAGE OF 1120 SILOS (1900 MTU) AT GOVERTMENT SITE WITHDUT EXISTING FACILITIES

$(2000,1987)$

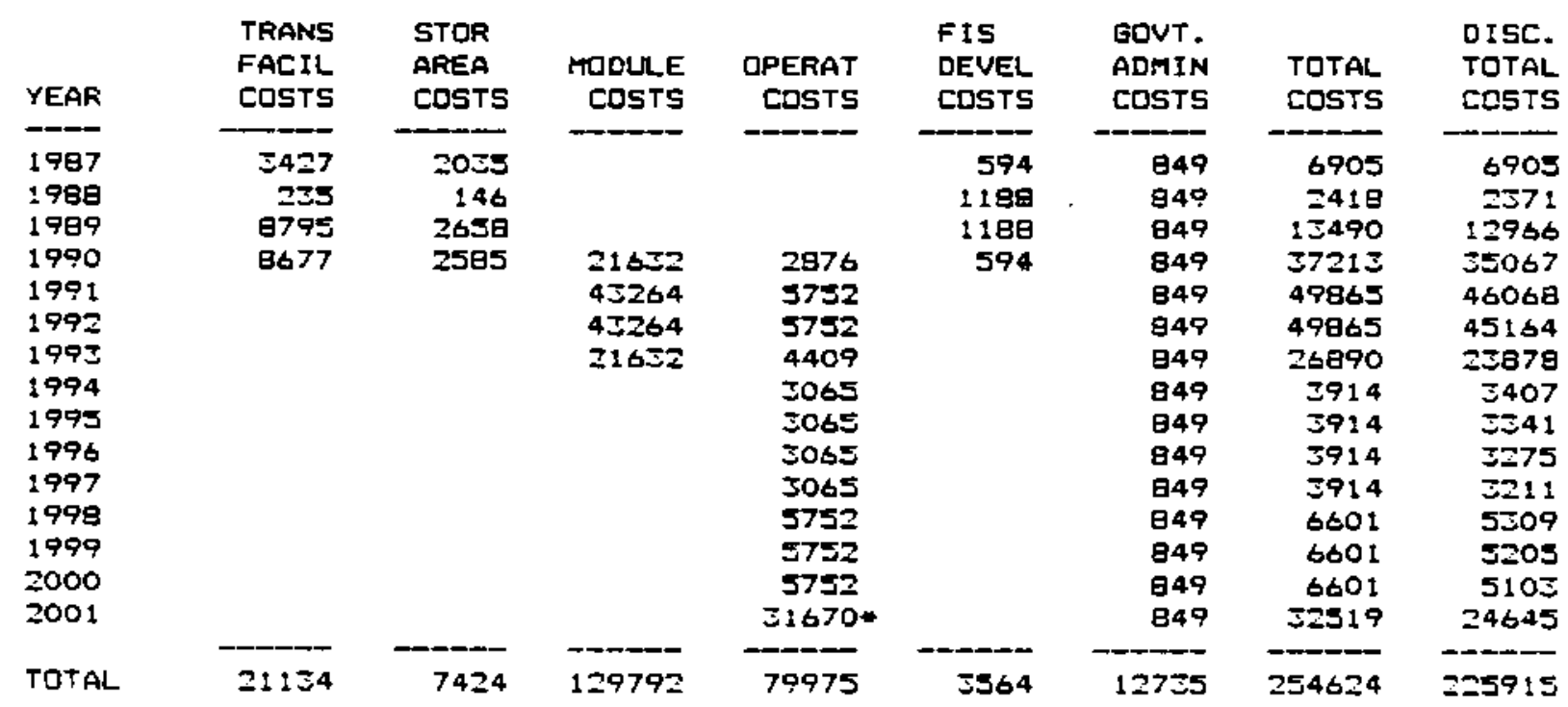

* Decammissioning east

\footnotetext{
Initial Payment $=04 \mathrm{t} / \mathrm{kgU}$ (Includes $\$ 4 / \mathrm{kgU}$ impact aid)

Final Fayment $=515 / \mathrm{Kg}$ (Includes $\$ 9 / \mathrm{kgU}$ impact aid)
} 
TABLE A9-20

ESTIMATED SFENDING SCHEDURE FOR STORAGE OF: 5 CASKS (5O MTU)

AT GOVERNMENT SITE WITH EXISTING FACILITIES

$(\$ 000,1807)$

\begin{tabular}{|c|c|c|c|c|c|c|c|c|}
\hline YEAR & $\begin{array}{l}\text { TFANS } \\
\text { FACIL } \\
\text { COSTS }\end{array}$ & $\begin{array}{l}\text { STOR } \\
\text { AREA } \\
\text { COSTS }\end{array}$ & $\begin{array}{l}\text { MODULE } \\
\text { CDSTS }\end{array}$ & $\begin{array}{r}\text { DFERAT } \\
\text { CUSTS }\end{array}$ & $\begin{array}{l}\text { FIS } \\
\text { DEVE:L } \\
\text { CDSTS }\end{array}$ & $\begin{array}{l}\text { GOVT. } \\
\text { ADMIN } \\
\text { COSTS }\end{array}$ & $\begin{array}{l}\text { TOTAL } \\
\text { COSTS }\end{array}$ & $\begin{array}{l}\text { DISC. } \\
\text { TOTAL } \\
\text { COSTS }\end{array}$ \\
\hline $\begin{array}{l}1987 \\
1998 \\
1999 \\
1990 \\
1991 \\
1992 \\
1993 \\
1994 \\
1995 \\
1996 \\
1997 \\
1990 \\
1999 \\
2000 \\
2001\end{array}$ & $\begin{array}{l}635 \\
107 \\
915 \\
961\end{array}$ & $\begin{array}{r}1058 \\
157 \\
456 \\
388\end{array}$ & $\begin{array}{r}956 \\
1912 \\
1912 \\
956\end{array}$ & $\begin{array}{r}990 \\
1797 \\
1797 \\
1392 \\
966 \\
966 \\
966 \\
966 \\
1797 \\
1797 \\
1797 \\
20554\end{array}$ & $\begin{array}{r}554 \\
11 E 1 \theta \\
11 E \theta \\
554\end{array}$ & $\begin{array}{l}129 \\
129 \\
128 \\
128 \\
128 \\
129 \\
129 \\
129 \\
129 \\
129 \\
129 \\
129 \\
128 \\
129 \\
128\end{array}$ & $\begin{array}{l}2396 \\
1560 \\
2697 \\
3626 \\
3957 \\
3857 \\
2466 \\
1094 \\
1094 \\
1094 \\
1094 \\
1925 \\
1925 \\
19=5 \\
2195\end{array}$ & $\begin{array}{r}2396 \\
1529 \\
2583 \\
5605 \\
3545 \\
5475 \\
2190 \\
952 \\
954 \\
915 \\
997 \\
1548 \\
1518 \\
1488 \\
1654\end{array}$ \\
\hline TETAL & 2518 & 2020 & 5756 & 17185 & 5564 & 1920 & 32945 & 29229 \\
\hline
\end{tabular}

- Decomissianing cost

Initial Payment $=275 x / k g l$ (Includes $15 / K g l$ impact aid)

Final Fayment $=3 \$ 35 / \mathrm{KLU}$ (Includes $510 / \mathrm{Kgl}$ impact aid)

TABLE A9-2I

ESTIMATED SPENDING SCHEDULE FOR STDRAGE OF 10 CASKS (100 MTU)

AT GOVERNMENT SITE WITH EXISTING FACILITIES

$(\$ 000,1997)$

\begin{tabular}{|c|c|c|c|c|c|c|c|c|}
\hline YEAR & $\begin{array}{l}\text { TRANS } \\
\text { FACIL } \\
\text { COSTS }\end{array}$ & $\begin{array}{l}\text { STOR } \\
\text { AREA } \\
\text { COSTS }\end{array}$ & $\begin{array}{l}\text { MCDULE } \\
\text { CDSTS }\end{array}$ & $\begin{array}{r}\text { OFEFAT } \\
\text { COSTS }\end{array}$ & $\begin{array}{l}\text { FIS } \\
\text { DEVEL } \\
\text { COSTS }\end{array}$ & $\begin{array}{l}\text { GDUT. } \\
\text { ADHIN } \\
\text { COSTS }\end{array}$ & $\begin{array}{l}\text { TOTAL } \\
\text { CUSTS }\end{array}$ & $\begin{array}{l}\text { DISC. } \\
\text { TOTAL } \\
\text { COSTS }\end{array}$ \\
\hline $\begin{array}{l}1987 \\
1906\end{array}$ & $\begin{array}{l}655 \\
107\end{array}$ & $\begin{array}{r}1043 \\
137\end{array}$ & & & $\begin{array}{r}594 \\
1189\end{array}$ & $\begin{array}{l}217 \\
217\end{array}$ & $\begin{array}{l}2489 \\
1649\end{array}$ & $\begin{array}{l}2489 \\
1617\end{array}$ \\
\hline 1989 & 915 & 471 & & & $119 \theta$ & 217 & 2791 & 2683 \\
\hline 1990 & 961 & 403 & 1912 & $9=6$ & 594 & 217 & 4923 & 4659 \\
\hline 1991 & & & 5925 & 1872 & & 217 & 5914 & 5464 \\
\hline 1992 & & & 5825 & 1872 & & 217 & 5914 & $5=56$ \\
\hline 1993 & & & 1912 & 1435 & & 217 & 3564 & 31 as \\
\hline 1994 & & & & 998 & & 217 & 1215 & 1058 \\
\hline 1995 & & & & 999 & & 217 & 1215 & $10 \leqslant 7$ \\
\hline 1996 & & & & 998 & & 217 & 1215 & 1017 \\
\hline 19077 & & & & 998 & & 217 & 1215 & 997 \\
\hline 1998 & & & & 1872 & & 217 & 2009 & $16 B O$ \\
\hline 1999 & & & & 1872 & & 217 & 2089 & 1647 \\
\hline 2000 & & & & 1日72 & & 217 & 2089 & 1615 \\
\hline 2001 & & & & $3209 *$ & & 217 & 3426 & 2586 \\
\hline TOTAL & 2518 & 2054 & $1: 474$ & 18972 & 3564 & 5:SS & $4 \$ 797$ & $=7060$ \\
\hline
\end{tabular}

* - Decommissianing cost

Initial Payment $=196 \mathrm{~s} / \mathrm{KgU}$ (Includes $55 / \mathrm{Kgl}$ impact aid)

Final Payment $=206 \mathrm{~s} / \mathrm{KgU}$ (Includes $110 / \mathrm{KgU}$ impact aid) 
TABLE A9-22

ESTIMATED SFENDING SCHEDULE FOR STORAGE OF 29 CASKS (300 MTU) AT GQVERNMENT SITE WITH EXISTING FACILITIES $(9000,1907)$

\begin{tabular}{|c|c|c|c|c|c|c|c|c|}
\hline YEAR & $\begin{array}{l}\text { TFANS } \\
\text { FACIL } \\
\text { COSTS }\end{array}$ & $\begin{array}{l}\text { STOR } \\
\text { AREA } \\
\text { COSTS }\end{array}$ & $\begin{array}{r}\text { MODULE } \\
\text { COSTS }\end{array}$ & $\begin{array}{r}\text { OFERAT } \\
\text { COSTS }\end{array}$ & $\begin{array}{l}\text { FIS } \\
\text { DEVEL } \\
\text { COSTS }\end{array}$ & $\begin{array}{l}\text { GOVT. } \\
\text { ADMIN } \\
\text { COSTS }\end{array}$ & $\begin{array}{l}\text { TOTAL } \\
\text { COSTS }\end{array}$ & $\begin{array}{l}\text { DISC. } \\
\text { TOTAL } \\
\text { CCSTS }\end{array}$ \\
\hline $\begin{array}{l}1997 \\
1988 \\
1989 \\
1990 \\
1991 \\
1992 \\
1995 \\
1994 \\
1995 \\
1996 \\
1997 \\
1990 \\
1999 \\
2000 \\
2001\end{array}$ & $\begin{array}{l}635 \\
107 \\
915 \\
961\end{array}$ & $\begin{array}{r}1057 \\
137 \\
510 \\
450\end{array}$ & $\begin{array}{r}5546 \\
11091 \\
11091 \\
5546\end{array}$ & $\begin{array}{l}1081 \\
2162 \\
2162 \\
1642 \\
1122 \\
1122 \\
1122 \\
1120 \\
2162 \\
2162 \\
2162 \\
7591\end{array}$ & $\begin{array}{r}594 \\
1199 \\
1189 \\
594\end{array}$ & 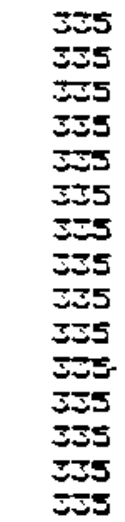 & $\begin{array}{r}2621 \\
1767 \\
2956 \\
8967 \\
13589 \\
15588 \\
7525 \\
1457 \\
1457 \\
1457 \\
1457 \\
2497 \\
2497 \\
2497 \\
7926\end{array}$ & $\begin{array}{r}26=1 \\
1732 \\
2941 \\
8356 \\
12553 \\
12507 \\
6680 \\
1268 \\
1244 \\
1219 \\
1195 \\
2008 \\
1969 \\
1930 \\
6007\end{array}$ \\
\hline TOTAL & 2518 & 2162 & $3=274$ & 25612 & 3564 & 5025 & 72155 & \\
\hline
\end{tabular}

* Decommissianing cost

Initial Payment $=157 \mathrm{~s} / \mathrm{Kgl}$ (Includes $15 / \mathrm{kgll}$ impact aid)

Final Payment $=99 \$ / \mathrm{Kg}$ (Includes $\$ 10 / \mathrm{Kgl}$ impact aid)

TABLE A9-23

ESTIMATED SPENDING SCHEDULE FOR STDRAGE OF 76 CASKS (900 MTU) AT GOVERNMENT SITE WITH EXISTING FACILITIES $(5000,1987)$

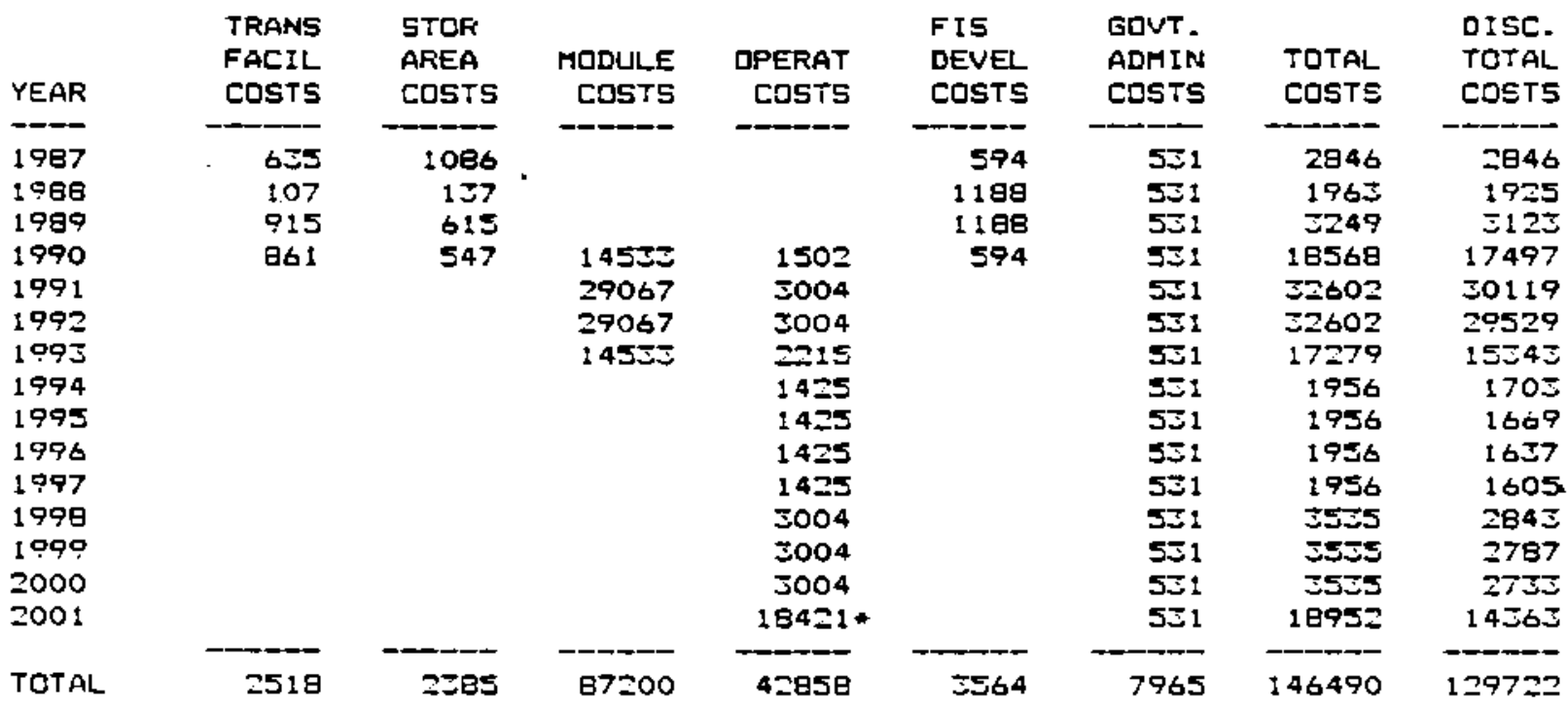

* Decommissianing cast

Initial Favment $=117 \mathrm{~s} / \mathrm{kg}$ U (Includes $5.5 / \mathrm{kgU}$ impact aid)

Final Fayment $=6 S 5 / \mathrm{Kg}$ (Includes $5: 10 / \mathrm{Kg}$ imoact aid) 
TABLE A9-24

ESTIMATED SPENDING SCHEDULE FOR STORAGE DF 14 J CASKS (1SO0 MTU) AT GOVERMMENT SITE WITH EXISTING FACILITIES

$(\$ 000,1987)$

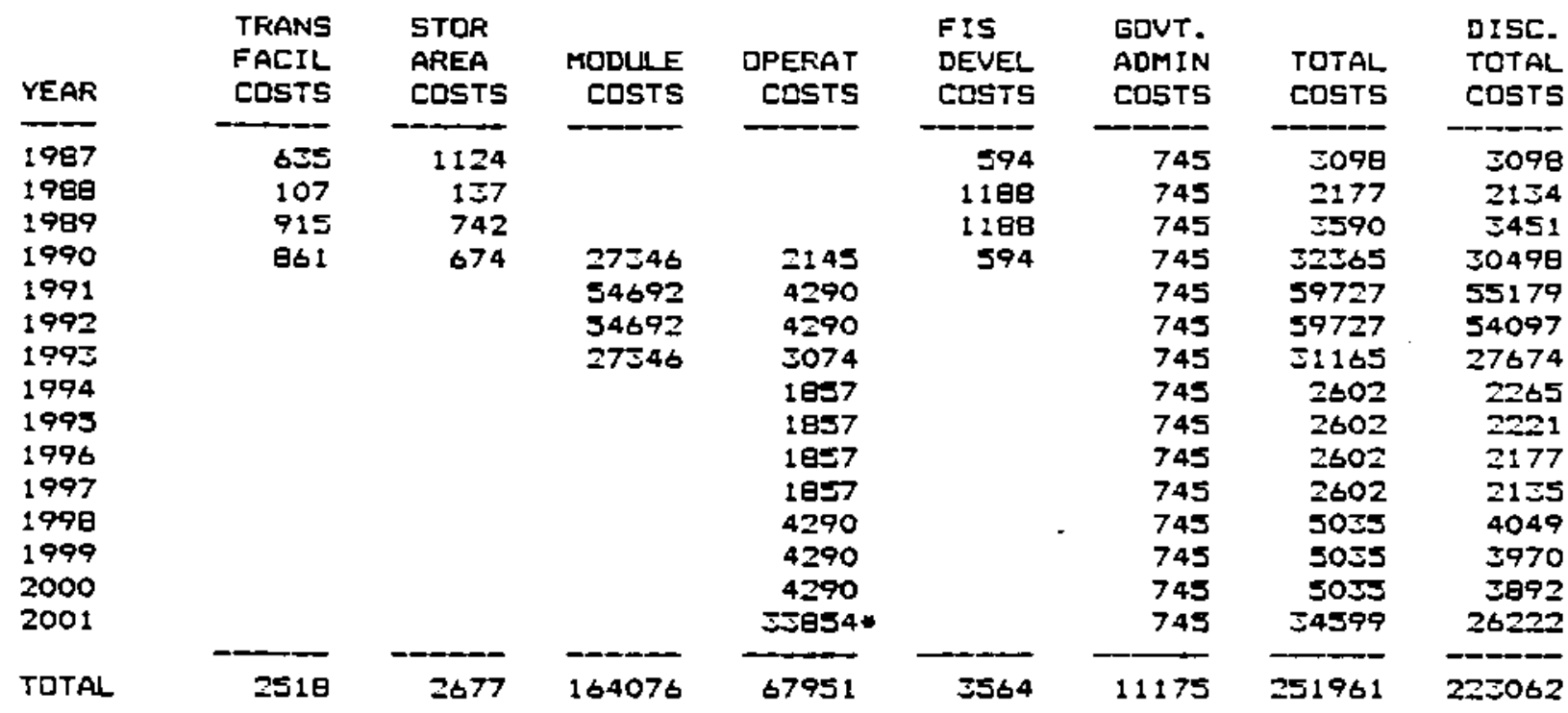

* - Decommissioning cost

Initial Payment $=112 \mathrm{k} / \mathrm{Kgl}$ (Includes $\mathrm{s}: \mathrm{K} / \mathrm{K} U \mathrm{U}$ impact aid)

Final Payment $=55 \mathrm{~s} / \mathrm{Kg} \mathrm{V}$ (Inclutes $510 / \mathrm{Kg}$ i mpact aid)

TABLE A9-25

ESTIMATED SPENDING SCHEDULE FOR STORAGE OF 19! CASKS (1900 MTU) AT GOVERNMENT SITE WITH EXISTING FACILITIES

$(5000,1997)$

\begin{tabular}{|c|c|c|c|c|c|c|c|c|}
\hline YEAR & $\begin{array}{l}\text { TRANS } \\
\text { FACIL } \\
\text { COSTS }\end{array}$ & $\begin{array}{l}\text { STOR } \\
\text { AREA } \\
\text { COSTS }\end{array}$ & $\begin{array}{r}\text { MODULE } \\
\text { COSTS }\end{array}$ & $\begin{array}{c}\text { DPSRAT } \\
\text { COSTS }\end{array}$ & $\begin{array}{l}\text { FIS } \\
\text { DEVEL } \\
\text { COSTS }\end{array}$ & $\begin{array}{l}\text { GOVT. } \\
\text { ADHIN } \\
\text { COSTS }\end{array}$ & $\begin{array}{l}\text { TOTAL } \\
\text { COSTS }\end{array}$ & $\begin{array}{l}\text { DISC. } \\
\text { TOTAL } \\
\text { COSTS }\end{array}$ \\
\hline 1987 & 655 & $\$ 145$ & & & 594 & 849 & 3233 & $s=23$ \\
\hline 1980 & 107 & $1=7$ & & & 1188 & 849 & 2281 & 2236 \\
\hline 1989 & 915 & 812 & & & I 180 & 849 & E04 & $\$ 618$ \\
\hline 1990 & 861 & 744 & I4613 & 2511 & 594 & 849 & $40: 72$ & 37855 \\
\hline 1991 & & & 69225 & 5022 & & 849 & 73096 & 69577 \\
\hline 1992 & & & $692=5$ & 5022 & & 849 & 75096 & 68017 \\
\hline 1993 & & & 34613 & 3562 & & 849 & 39024 & 34652 \\
\hline 1994 & & & & 2102 & & 849 & 2951 & 2569 \\
\hline 1995 & & & & 2102 & & 849 & 2951 & 2519 \\
\hline 1996 & & & & 2102 & & 849 & $\cong 951$ & 2469 \\
\hline 1997 & & & & $=102$ & & 849 & 2951 & 2421 \\
\hline 1998 & & & & $50 \geq 2$ & & 949 & 5871 & $47 \geq 2$ \\
\hline 1999 & & & & 5022 & & 849 & 5971 & 4629 \\
\hline 2000 & & & & 5022 & & 849 & 5071 & 4530 \\
\hline 2001 & & & & $42606 *$ & & 849 & 43455 & $\Xi 2933$ \\
\hline TOTAL & 2518 & 2858 & 207676 & 82197 & $35 \leq 4$ & 12755 & $5115=8$ & 275779 \\
\hline
\end{tabular}

* - Decommissigning cost

Initial Fayment $=1115 / \mathrm{KgL}$ (Inctudes $75 / \mathrm{Kg}$ impact aid)

Final Fayment $=5 z \quad 5 / k g U$ (Inclubes $510 / k g U$ impact aid) 
TABLE A9-26

ESTIMATED SPENDING 5CHEDULE FOR STORAGE OF 119 DRYWELLS (SO HTU) AT GDVERNMENT SITE WITH EXISTING FACILITIES (\$000, 1987)

\begin{tabular}{|c|c|c|c|c|c|c|c|c|}
\hline YEAR & $\begin{array}{l}\text { TRANS } \\
\text { FACIL } \\
\text { COSTS }\end{array}$ & $\begin{array}{l}\text { STOK } \\
\text { AREA } \\
\text { CDSTS }\end{array}$ & $\begin{array}{l}\text { MODLLEE } \\
\text { COSTS }\end{array}$ & $\begin{array}{r}\text { QFERAT } \\
\text { CCSTS }\end{array}$ & $\begin{array}{l}\text { FIS } \\
\text { DEVEL } \\
\text { CDSTS }\end{array}$ & $\begin{array}{l}\text { GDVT. } \\
\text { ADMIN } \\
\text { CDSTS }\end{array}$ & $\begin{array}{l}\text { TOTAL } \\
\text { COSTS }\end{array}$ & $\begin{array}{l}\text { DISC. } \\
\text { TOTAL } \\
\text { COSTS }\end{array}$ \\
\hline $\begin{array}{l}1987 \\
1989 \\
1999 \\
1990 \\
1991 \\
1992 \\
1993 \\
1994 \\
1995 \\
1996 \\
1997 \\
1998 \\
1999 \\
2000 \\
2001\end{array}$ & $\begin{array}{r}1509 \\
107 \\
3226 \\
577\end{array}$ & $\begin{array}{r}1680 \\
146 \\
1934 \\
1961\end{array}$ & $\begin{array}{l}495 \\
989 \\
989 \\
495\end{array}$ & $\begin{array}{l}985 \\
1970 \\
1970 \\
1544 \\
1119 \\
1118 \\
1118 \\
1118 \\
1970 \\
1970 \\
1970 \\
5561\end{array}$ & $\begin{array}{r}594 \\
1188 \\
1180 \\
594\end{array}$ & $\begin{array}{l}128 \\
128 \\
128 \\
128 \\
129 \\
128 \\
128 \\
128 \\
129 \\
128 \\
128 \\
129 \\
128 \\
128 \\
129\end{array}$ & $\begin{array}{l}3910 \\
1569 \\
7076 \\
7936 \\
3087 \\
3087 \\
2167 \\
1246 \\
1246 \\
1246 \\
1246 \\
2096 \\
2098 \\
2098 \\
3689\end{array}$ & $\begin{array}{l}5910 \\
1538 \\
6801 \\
7384 \\
2852 \\
2796 \\
1924 \\
1085 \\
1063 \\
1043 \\
1022 \\
1687 \\
1654 \\
1622 \\
2796\end{array}$ \\
\hline TOTAL & 9214 & 5621 & 2968 & 20412 & J564 & 1920 & 43699 & $\$ 9177$ \\
\hline
\end{tabular}

- Decommissioning cost

Initial Payment * 421 \$ Kgl (Includes Is/Kgl impact aid)

Final Payment $=412$ tKgu (Includes $\$ 10 / \mathrm{KgU}$ impact aid)

TABLE A9-27

ESTIMATED SPENDING SCHEDULE FOR STORAGE OF 230 DRYWELLS ( 100 MTU) AT GOVERNMENT SITE WITH EXISTING FACILITIES $(1000,1987)$

\begin{tabular}{|c|c|c|c|c|c|c|c|c|}
\hline YEAR & $\begin{array}{l}\text { TRANS } \\
\text { FACIL } \\
\text { COSTS }\end{array}$ & $\begin{array}{l}\text { STOR } \\
\text { AFEA } \\
\text { COST5 }\end{array}$ & $\begin{array}{r}\text { MODULE } \\
\text { COSTS }\end{array}$ & $\begin{array}{r}\text { OPERAT } \\
\text { COSTS }\end{array}$ & $\begin{array}{l}\text { FIS } \\
\text { DEVEL } \\
\text { COSTS }\end{array}$ & $\begin{array}{l}\text { GDVT. } \\
\text { ADHIN } \\
\text { COSTS }\end{array}$ & $\begin{array}{l}\text { TOTAL } \\
\text { COSTS }\end{array}$ & $\begin{array}{l}\text { DISE. } \\
\text { TOTAL } \\
\text { COSTS }\end{array}$ \\
\hline $\begin{array}{l}1997 \\
1998 \\
1999 \\
1990 \\
1991 \\
1992 \\
1995 \\
1994 \\
1995 \\
1996 \\
1997 \\
1998 \\
1999 \\
2000 \\
2001\end{array}$ & $\begin{array}{r}1500 \\
107 \\
3826 \\
3773\end{array}$ & $\begin{array}{r}1697 \\
146 \\
1992 \\
1919\end{array}$ & $\begin{array}{r}989 \\
1978 \\
1979 \\
989\end{array}$ & $\begin{array}{l}1050 \\
2099 \\
2099 \\
1619 \\
1156 \\
1156 \\
11 \pm 6 \\
1126 \\
2090 \\
2099 \\
2099 \\
4190\end{array}$ & $\begin{array}{r}594 \\
1199 \\
1199 \\
594\end{array}$ & $\begin{array}{l}217 \\
217 \\
217 \\
217 \\
217 \\
217 \\
217 \\
217 \\
217 \\
217 \\
217 \\
217 \\
217 \\
217 \\
217\end{array}$ & $\begin{array}{l}4016 \\
1658 \\
7223 \\
2542 \\
4294 \\
4294 \\
2924 \\
1353 \\
1553 \\
1253 \\
1=53 \\
2516 \\
2316 \\
2516 \\
4597\end{array}$ & $\begin{array}{l}4016 \\
1625 \\
6943 \\
8040 \\
3967 \\
3889 \\
2508 \\
1170 \\
1195 \\
1132 \\
1110 \\
1867 \\
1826 \\
1790 \\
5332\end{array}$ \\
\hline TUTAL & 9214 & 5754 & $59=4$ & こะ日日7 & 3564 & 3255 & $4960 B$ & 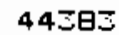 \\
\hline
\end{tabular}

- Decammissioning cost

\footnotetext{
Initial fayment $=244 \mathrm{~s} / \mathrm{KgU}$ (Includes $25 / \mathrm{Kgl}$ impact aid)

Final Fayment $=234$ tKgl (Includes $510 / \mathrm{kg}$ impact aid)
} 
TABLE A9-28

ESTIMATED SFENDING SCHEDULE FOR STORAGE QF 707 ORYWELLS (300 MTU)

AT GQVERNMENT SITE WITH EXISTING FALILITIES $(5.000,1987)$

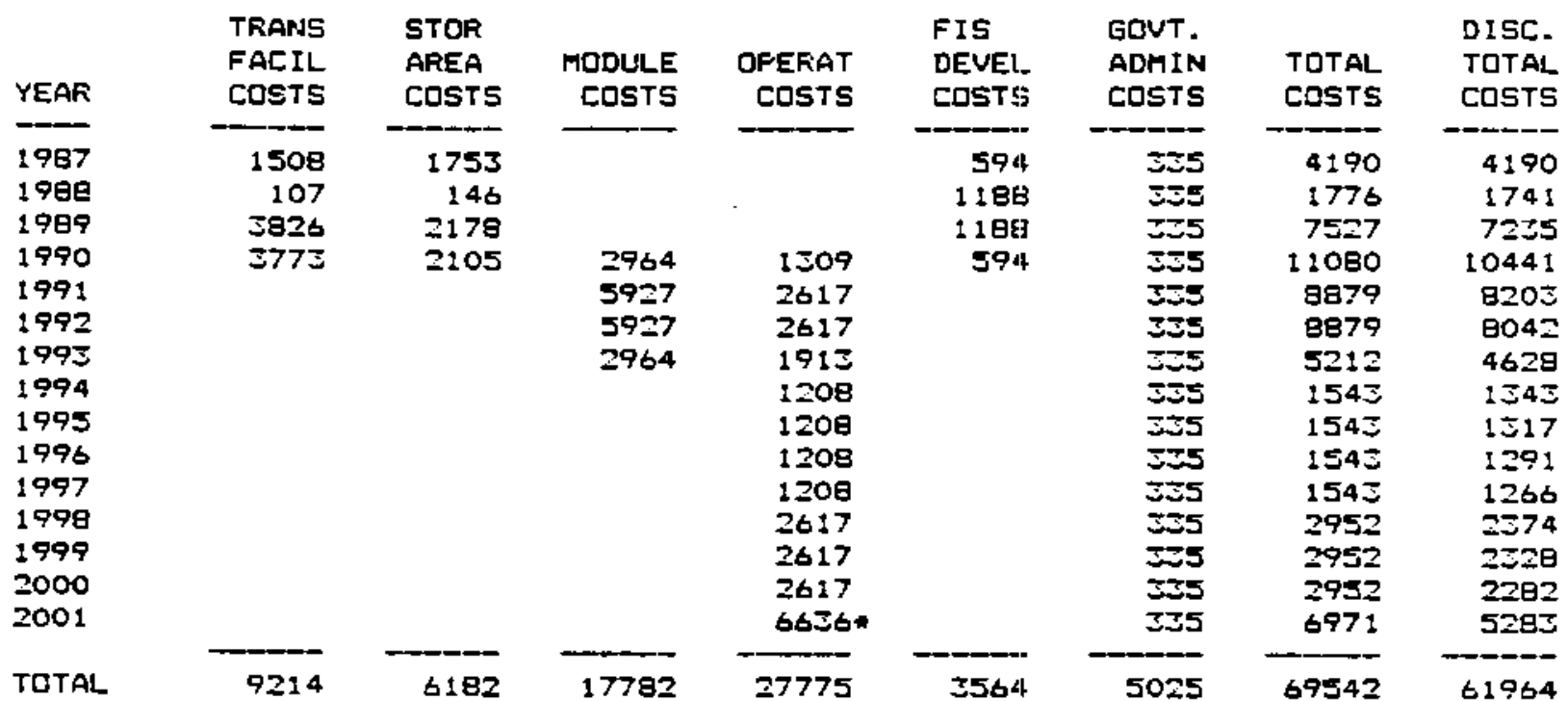

* - Decommissigning cost

Initial Payment = $124 \mathrm{~s} / \mathrm{KgU}$ (Includes $55 / \mathrm{Kgl}$ impact aid)

Final Payment $=106 \% / \mathrm{Kgl}$ (Includes $510 / \mathrm{KglJ}$ impact aid)

TABLE A9-29

ESTIMATED SPENDING SCHEDULE FOR STORAGE OF 1986 DRYWELLS (BOO MTU) AT GQVERNUENT SITE WITH EXISTING FACILITIES

$(\$ 000,1987)$

\begin{tabular}{|c|c|c|c|c|c|c|c|c|c|}
\hline YEAR & & $\begin{array}{l}\text { TRANS } \\
\text { FALIL } \\
\text { COSTS }\end{array}$ & $\begin{array}{l}\text { STOR } \\
\text { AREA } \\
\text { COSTS }\end{array}$ & $\begin{array}{l}\text { MODULE } \\
\text { COSTS }\end{array}$ & $\begin{array}{r}\text { OPERAT } \\
\text { COSTS }\end{array}$ & $\begin{array}{l}\text { FIS } \\
\text { DEVEl. } \\
\text { COSTS }\end{array}$ & $\begin{array}{l}\text { GOVT. } \\
\text { ADMIN } \\
\text { COSTS }\end{array}$ & $\begin{array}{l}\text { TOTAL } \\
\text { CDSTS }\end{array}$ & $\begin{array}{l}\text { DISC. } \\
\text { TOTAL } \\
\text { COSTS }\end{array}$ \\
\hline 1997 & & 1508 & 1875 & & & 394 & $5 \Sigma 1$ & 4506 & 4506 \\
\hline 1998 & $\cdots$ & 107 & 146 & & & 1188 & $5 \equiv 1$ & 1972 & 1933 \\
\hline 1909 & & 3826 & $=578$ & & & 1:86 & $5 \Xi 1$ & $\theta 125$ & 7800 \\
\hline 1990 & & $\Sigma 77 \Sigma$ & 2505 & 7905 & $201=$ & 594 & $\Xi \Xi 1$ & 17323 & $16 \Xi 24$ \\
\hline 1991 & & & & 15811 & $40 \Xi 0$ & & $5 \Xi 1$ & 20572 & $198 \geq 1$ \\
\hline 1992 & & & & 15911 & 4030 & & $5=1$ & 20372 & 18452 \\
\hline 1993 & & & & 7905 & 2706 & & $5=1$ & 11142 & 9894 \\
\hline 1994 & & & & & 1382 & & $5=1$ & $191 \equiv$ & 1665 \\
\hline 1995 & & & & & 1302 & & $\sum 1$ & 1913 & $165=$ \\
\hline 1996 & & & & & 1382 & & $5 \Xi 1$ & 1913 & 1601 \\
\hline 1997 & & & & & 1302 & & 531 & 1913 & 1569 \\
\hline 1998 & & & & & $40 \equiv 0$ & & $5=1$ & 4561 & 5668 \\
\hline 1999 & & & & & 4030 & & 231 & 4561 & 3596 \\
\hline 2000 & & & & & $40=0$ & & ここ1 & 4561 & 5526 \\
\hline 2001 & & & & & $12750 *$ & & $5 \Xi 1$ & $1 \leq 281$ & 10065 \\
\hline TOTAL & & 9214 & 7102 & $474 \Xi 2$ & 43149 & E564 & 7965 & 119426 & 105061 \\
\hline
\end{tabular}

* Decommissioning cost

\footnotetext{
Initial Payment $=85 . / \mathrm{Kg}$ (Includes $55 / \mathrm{KgU}$ impact aid)

Final Fayment $=$ bo $5 / K g U$ (Incluges $\$ 10 / K g l$ impact aid)
} 
TABLE A9-30

ESTIMATED SPENDING SCHEDULE FOR STORAGE OF ZEZS DRYWELLS (1500 MTU)

AT GQVERNMENT SITE WITH EXISTING FACILITIES $( \pm 000,1987)$

\begin{tabular}{|c|c|c|c|c|c|c|c|c|}
\hline YEAR & $\begin{array}{l}\text { TRANS } \\
\text { FACIL } \\
\text { CASTS }\end{array}$ & $\begin{array}{l}\text { STOR } \\
\text { AREA } \\
\text { COST5 }\end{array}$ & $\begin{array}{r}\text { MODLLE } \\
\text { COSTS }\end{array}$ & $\begin{array}{r}\text { DFERAT } \\
\text { COSTS }\end{array}$ & $\begin{array}{l}\text { FIS } \\
\text { DEVEL } \\
\text { CDSTS }\end{array}$ & $\begin{array}{l}\text { GOVT. } \\
\text { ADMIN } \\
\text { CDSTS }\end{array}$ & $\begin{array}{l}\text { TOTAL } \\
\text { COSTS }\end{array}$ & $\begin{array}{l}\text { DISC. } \\
\text { TUTAL } \\
\text { CDSTS }\end{array}$ \\
\hline $\begin{array}{l}1987 \\
1990 \\
1999 \\
1990 \\
1991 \\
1997 \\
1995 \\
1994 \\
1995 \\
1996 \\
1997 \\
1998 \\
1999 \\
2000 \\
2001\end{array}$ & $\begin{array}{r}1509 \\
107 \\
3826 \\
5775\end{array}$ & $\begin{array}{r}2026 \\
146 \\
5094 \\
5021\end{array}$ & $\begin{array}{l}14818 \\
29655 \\
29655 \\
14818\end{array}$ & $\begin{array}{l}3081 \\
6162 \\
6162 \\
3913 \\
1663 \\
166 J \\
1663 \\
1663 \\
6162 \\
6162 \\
6162 \\
21292\end{array}$ & $\begin{array}{r}594 \\
1190 \\
1199 \\
594\end{array}$ & $\begin{array}{l}745 \\
745 \\
745 \\
745 \\
745 \\
745 \\
745 \\
745 \\
745 \\
745 \\
745 \\
745 \\
745 \\
745 \\
745\end{array}$ & $\begin{array}{r}4875 \\
2186 \\
8853 \\
26032 \\
36542 \\
36542 \\
19476 \\
2408 \\
2408 \\
2408 \\
2408 \\
6907 \\
6907 \\
6907 \\
22027\end{array}$ & $\begin{array}{r}4875 \\
2145 \\
2509 \\
24531 \\
3 \Xi 759 \\
55097 \\
17294 \\
2096 \\
2055 \\
2015 \\
1575 \\
5555 \\
5446 \\
5539 \\
16694\end{array}$ \\
\hline TOTAL & 9214 & 8289 & 88906 & 65738 & 3564 & 11175 & 186886 & 6550 \\
\hline
\end{tabular}

* - Decommissianing cost

Initial Payment $=73$ 1/KgU (Includes $\$ 4 / \mathrm{Kg}$ impact aid)

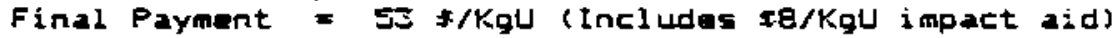

TABLE A9-31

ESTIMATED SPENDING SCHEDULE FDR STORAGE OF 4470 DRYWELLS $12900 \mathrm{MTU})$ AT GOVERNMENT SITE WITH EXISTING FACILITIES $( \pm 000,19 \theta 7)$

\begin{tabular}{|c|c|c|c|c|c|c|c|}
\hline YEAR & $\begin{array}{l}\text { TRANS } \\
\text { FACIL } \\
\text { COSTS }\end{array}$ & $\begin{array}{l}\text { STOR } \\
\text { AREA } \\
\text { COSTS }\end{array}$ & $\begin{array}{l}\text { MODULE } \\
\text { COSTS }\end{array}$ & $\begin{array}{r}\text { OPERAT } \\
\text { COSTS }\end{array}$ & $\begin{array}{l}\text { FIS } \\
\text { DEVEL } \\
\text { COSTS }\end{array}$ & $\begin{array}{l}\text { GOUT. } \\
\text { ADMIN } \\
\text { COSTS }\end{array}$ & $\begin{array}{l}\text { TUTAL } \\
\text { COSTS }\end{array}$ \\
\hline $\begin{array}{l}1597 \\
1989\end{array}$ & $\begin{array}{r}1508 \\
107\end{array}$ & 2113 & & & 594 & 849 & 5064 \\
\hline $\begin{array}{l}1980 \\
1989\end{array}$ & ze26 & & & & $\begin{array}{l}1180 \\
1190\end{array}$ & $\begin{array}{l}847 \\
849\end{array}$ & 9242 \\
\hline 1990 & 3775 & $3 \$ 06$ & 18770 & 3690 & 594 & 849 & 50902 \\
\hline 1991 & & & 37541 & $7 \Xi 80$ & & 849 & 45770 \\
\hline 1992 & & & 37541 & 7380 & & 849 & 45770 \\
\hline 1993 & & & 18770 & 4602 & & 849 & 24221 \\
\hline 1994 & & & & $182 z$ & & 849 & 2672 \\
\hline 1995 & & & & $19 \geq z$ & & B49 & 2672 \\
\hline 1996 & & & & 2823 & & 849 & 2672 \\
\hline 1097 & & & & $18 \geq 3$ & & 849 & 2672 \\
\hline 1998 & & & & 7380 & & 849 & 8229 \\
\hline 1999 & & & & тร80 & & 849 & 8229 \\
\hline 2000 & & & & 7580 & & 849 & 9229 \\
\hline 2001 & & & & $26156 *$ & & 849 & 27005 \\
\hline & 9214 & 444 & $26=2$ & 78640 & 5564 & $=5$ & $7=57$ \\
\hline
\end{tabular}

* - Decommissioning cost

\footnotetext{
Initial Payment $=71 \mathrm{x} / \mathrm{Kgl}$ (Includes $1.4 / \mathrm{KgU}$ impact aid)

Final Fayment = 5o $t / \mathrm{kgU}$ (includes $5 g / \mathrm{kg}$ impact aid)
} 
TABLE A9-32

ESTIMATED SFENDING SCHEDULE FUR STORAGE OF 30 SILOS (SO MTU) AT GDVERNMENT SITE WITH EXISTING FACILITIES $(1000,1987)$

\begin{tabular}{|c|c|c|c|c|c|c|c|c|}
\hline YEAR & $\begin{array}{l}\text { TRANS } \\
\text { FAEIL } \\
\text { EOSTS }\end{array}$ & $\begin{array}{l}\text { STOR } \\
\text { AREA } \\
\text { COSTS }\end{array}$ & $\begin{array}{r}\text { MODLLE } \\
\text { COSTS }\end{array}$ & $\begin{array}{r}\text { OPERAT } \\
\text { COSTS }\end{array}$ & $\begin{array}{l}\text { FIS } \\
\text { DEVEL. } \\
\text { COSTS; }\end{array}$ & $\begin{array}{l}\text { GOVT. } \\
\text { ADHIN } \\
\text { COSTS }\end{array}$ & $\begin{array}{l}\text { TOTAL } \\
\text { COSTS }\end{array}$ & $\begin{array}{l}\text { DISE. } \\
\text { TUTAL } \\
\text { EOSTS }\end{array}$ \\
\hline $\begin{array}{l}1987 \\
1990 \\
1999 \\
1990 \\
1991 \\
1992 \\
1993 \\
1994 \\
1995 \\
1996 \\
1997 \\
1990 \\
1999 \\
2000 \\
2001\end{array}$ & $\begin{array}{r}1509 \\
107 \\
5829 \\
3775\end{array}$ & $\begin{array}{r}1402 \\
146 \\
946 \\
473\end{array}$ & $\begin{array}{r}578 \\
1156 \\
1156 \\
578\end{array}$ & $\begin{array}{c}939 \\
1979 \\
1979 \\
1467 \\
1056 \\
1056 \\
1056 \\
1056 \\
1878 \\
1978 \\
1978 \\
3051\end{array}$ & $\begin{array}{r}594 \\
118 B \\
1198 \\
594 .\end{array}$ & $\begin{array}{l}128 \\
128 \\
128 \\
128 \\
128 \\
128 \\
129 \\
128 \\
128 \\
128 \\
128 \\
128 \\
128 \\
128 \\
128\end{array}$ & $\begin{array}{l}5633 \\
1569 \\
5691 \\
6487 \\
3162 \\
3162 \\
2173 \\
1184 \\
1184 \\
1184 \\
1184 \\
2006 \\
2006 \\
2006 \\
3179\end{array}$ & $\begin{array}{r}3453 \\
1550 \\
5470 \\
6113 \\
2921 \\
2864 \\
1950 \\
1031 \\
1011 \\
091 \\
971 \\
1613 \\
1582 \\
1551 \\
2409\end{array}$ \\
\hline TUTAL & 9220 & 2567 & $\equiv 46 \theta$ & 19071 & 3564 & 1920 & 39010 & 35629 \\
\hline
\end{tabular}

- Decommissioning cast

Initial Payment $=\$ 7 z \$ / K g U$ (Includes $55 / K g U$ impact aid)

Final fayment = $39 \theta+\mathrm{KgU}$ (Includes $\pm 10 / \mathrm{KgU}$ impact aid)

TABLE A9-33

ESTIMATED SPENDING SCHEDLLE FOR STORAGE OF 59 SILOS (100 MTU) AT GOVERMMENT SITE WITH EXISTING FACILITIES $(5000,1987)$

\begin{tabular}{|c|c|c|c|c|c|c|c|c|}
\hline YEAR & $\begin{array}{l}\text { TRANS } \\
\text { FACIL } \\
\text { CDSTS }\end{array}$ & $\begin{array}{l}\text { STOR } \\
\text { AREA } \\
\text { COSTS }\end{array}$ & $\begin{array}{l}\text { MODULE } \\
\text { COSTS }\end{array}$ & $\begin{array}{r}\text { OPERAT } \\
\text { COSTS }\end{array}$ & $\begin{array}{l}\text { FIS } \\
\text { DEVEL } \\
\text { COSTS }\end{array}$ & $\begin{array}{l}\text { GQVT. } \\
\text { ADMIN } \\
\text { COSTS }\end{array}$ & $\begin{array}{l}\text { TOTAL } \\
\text { COSTS }\end{array}$ & $\begin{array}{l}\text { DISC. } \\
\text { TOTAL } \\
\text { COSTS }\end{array}$ \\
\hline 1987 & 1509 & 1423 & & & 594 & 217 & $\$ 43$ & 5745 \\
\hline 1990 & 107 & 146 & & & 1 180 & 217 & 1658 & 1625 \\
\hline 1989 & 3929 & big & & & 1189 & 217 & 5852 & 5625 \\
\hline 1990 & 5775 & 545 & 1240 & 996 & 394 & 217 & 7267 & 6048 \\
\hline 1991 & & & $2 \geq 79$ & 1992 & & 217 & 4409 & 4146 \\
\hline 1992 & & & 2799 & 1992 & & $\equiv 17$ & $44 B B$ & 4005 \\
\hline 1995 & & & 1140 & $15=6$ & & 217 & 2993 & 7569 \\
\hline 1994 & & & & 1079 & & 217 & 1296 & 1128 \\
\hline 1095 & & & & $107 \%$ & & 217 & 1296 & 1106 \\
\hline 1996 & & & & 1079 & & 217 & 1296 & 1094 \\
\hline 1997 & & & & 1079 & & 217 & 1296 & 1063 \\
\hline 1998 & & & & 1992 & & $\equiv 17$ & $2=09$ & 1777 \\
\hline 1999 & & & & 1992 & & 217 & 2209 & 1742 \\
\hline 2000 & & & & 1992 & & 217 & 2209 & 1700 \\
\hline 2001 & & & & $5758 *$ & & 217 & 3975 & 3013 \\
\hline TOTAL & $9=20$ & 2732 & $68 \div 8$ & 20566 & 5564 & $3=55$ & 46175 & 41242 \\
\hline
\end{tabular}

* - Decommissianing cost

Initial Fayment $=224 \$ / K g l$ (Includes $\$ 5 / K g L$ impact aid)

Final Payment $=I=5 / k g U$ (Includes $x: 10 / k$ gu impact aid) 
TABLE A9-34

ESTIMATED SPENDING SCHEDULE FOF STORAGE OF 177 SILOS (SOO MTU) AT GDVERNMENT SITE WITH EXISTING FACILITIES (x000, 1907)

\begin{tabular}{|c|c|c|c|c|c|c|c|c|}
\hline YEAR & $\begin{array}{l}\text { TRANS } \\
\text { FACIL } \\
\text { COSTS }\end{array}$ & $\begin{array}{l}\text { STOR } \\
\text { AFEA } \\
\text { CDSTS }\end{array}$ & $\begin{array}{l}\text { MODULE } \\
\text { COSTS }\end{array}$ & $\begin{array}{r}\text { QPERAT } \\
\text { COSTS }\end{array}$ & $\begin{array}{l}\text { FIS } \\
\text { DEVEL } \\
\text { COSTS }\end{array}$ & $\begin{array}{l}\text { GOVT. } \\
\text { ADMIN } \\
\text { COSTS }\end{array}$ & $\begin{array}{l}\text { TOTAL } \\
\text { COSTS }\end{array}$ & $\begin{array}{l}\text { DISC. } \\
\text { TOTAL } \\
\text { CDSTS }\end{array}$ \\
\hline $\begin{array}{l}1997 \\
1988 \\
1989 \\
1990 \\
1991 \\
1992 \\
1993 \\
1994 \\
1995 \\
1996 \\
1997 \\
1996 \\
1999 \\
2000 \\
2001\end{array}$ & $\begin{array}{r}1509 \\
107 \\
3829 \\
3775\end{array}$ & $\begin{array}{l}1502 \\
146 \\
890 \\
907\end{array}$ & $\begin{array}{l}3419 \\
6836 \\
6836 \\
3418\end{array}$ & $\begin{array}{l}1169 \\
2338 \\
2530 \\
1748 \\
1158 \\
1158 \\
1158 \\
1158 \\
2330 \\
2358 \\
2538 \\
6615 *\end{array}$ & $\begin{array}{r}594 \\
1189 \\
1188 \\
594\end{array}$ & 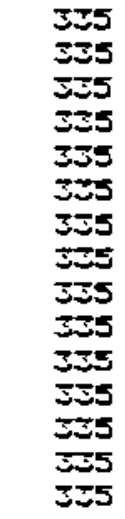 & $\begin{array}{r}3940 \\
1776 \\
6232 \\
10098 \\
9509 \\
9509 \\
5501 \\
1493 \\
1493 \\
1493 \\
1493 \\
2673 \\
2673 \\
2673 \\
6948\end{array}$ & $\begin{array}{l}3940 \\
1741 \\
5990 \\
9516 \\
8795 \\
8613 \\
4885 \\
1300 \\
1274 \\
1249 \\
1275 \\
2150 \\
2100 \\
2066 \\
5266\end{array}$ \\
\hline TOTAL & $9 \geq 20$ & 3335 & 20500 & 25852 & $5=64$ & 5025 & 67504 & 60100 \\
\hline
\end{tabular}

* - Decommissioning cost

Initial Payment $=123+\mathrm{KgU}$ (Ineludes $15 / \mathrm{Kgl}$ impact aid)

Final Payment $\Rightarrow 100$ e/Kgü (Includes $\$ 10 / \mathrm{Kgl}$ impact aid)

TABLE A9-35

ESTIMATED SPENDING SCHEDULE FDR STORAGE OF 471 SILOS (80O MTU) AT GOVERNMENT SITE WITH EXISTING FACILITIES $(9000,1987)$

\begin{tabular}{|c|c|c|c|c|c|c|c|c|}
\hline YEAR & $\begin{array}{l}\text { TRANS } \\
\text { FACIL } \\
\text { CUSTS }\end{array}$ & $\begin{array}{l}\text { STOR } \\
\text { AREA } \\
\text { CDSTS }\end{array}$ & $\begin{array}{l}\text { MODLLE } \\
\text { COSTS }\end{array}$ & $\begin{array}{r}\text { OPERAT } \\
\text { COSTS }\end{array}$ & $\begin{array}{l}\text { FIS } \\
\text { DEVEL } \\
\text { COSTS }\end{array}$ & $\begin{array}{l}\text { GOVT. } \\
\text { ADMIN } \\
\text { CDSTS }\end{array}$ & $\begin{array}{l}\text { TOTAL } \\
\text { COSTS }\end{array}$ & $\begin{array}{l}\text { DISC. } \\
\text { TOTAL } \\
\text { COSTS }\end{array}$ \\
\hline $\begin{array}{l}1987 \\
1998 \\
1999 \\
1990 \\
1991 \\
1992 \\
1993 \\
1994 \\
1995 \\
1996 \\
1997 \\
1990 \\
1999 \\
2000 \\
2001\end{array}$ & $\begin{array}{r}1509 \\
107 \\
3829 \\
5775\end{array}$ & $\begin{array}{r}1682 \\
146 \\
1492 \\
1409\end{array}$ & $\begin{array}{r}9099 \\
19198 \\
18198 \\
9099\end{array}$ & $\begin{array}{l}1784 \\
3567 \\
3567 \\
2467 \\
1358 \\
1358 \\
1358 \\
1358 \\
5567 \\
3567 \\
3567 \\
15707 *\end{array}$ & $\begin{array}{r}594 \\
1289 \\
1198 \\
594\end{array}$ & $\begin{array}{l}5=1 \\
531 \\
531 \\
5=1 \\
531 \\
5=1 \\
5 \pm 1 \\
5=1 \\
5=1 \\
531 \\
5=1 \\
5=1 \\
5=1 \\
5=1 \\
531\end{array}$ & $\begin{array}{r}4316 \\
1972 \\
7030 \\
17192 \\
22796 \\
27996 \\
12095 \\
1899 \\
1999 \\
1989 \\
1889 \\
4096 \\
4098 \\
4098 \\
14239\end{array}$ & $\begin{array}{r}4316 \\
1935 \\
6757 \\
16200 \\
20596 \\
20194 \\
10750 \\
1444 \\
1612 \\
1581 \\
1550 \\
3296 \\
3231 \\
5168 \\
10791\end{array}$ \\
\hline TOTAL & 9220 & 4719 & 54594 & 41221 & 3564 & 7965 & $1212 \mathrm{BZ}$ & 10760 \\
\hline
\end{tabular}

* - Decammissioning cost

Initial Payment = 91 t/KgU (Includes $55 / \mathrm{KgU}$ impact aid?

Final Fayment $=t \Xi \pm / K g U$ (Includes $5: 0 / \mathrm{Kg} U$ impact aid) 
TABLE A9-36

ESTIMATED SPENDING SCHEDULE FOR STORAGE OF BG4 SILUS (1500 MTU) AT GOVERNMENT SITE WITH EXISTING FACILITIES $(\$ 000,1987)$

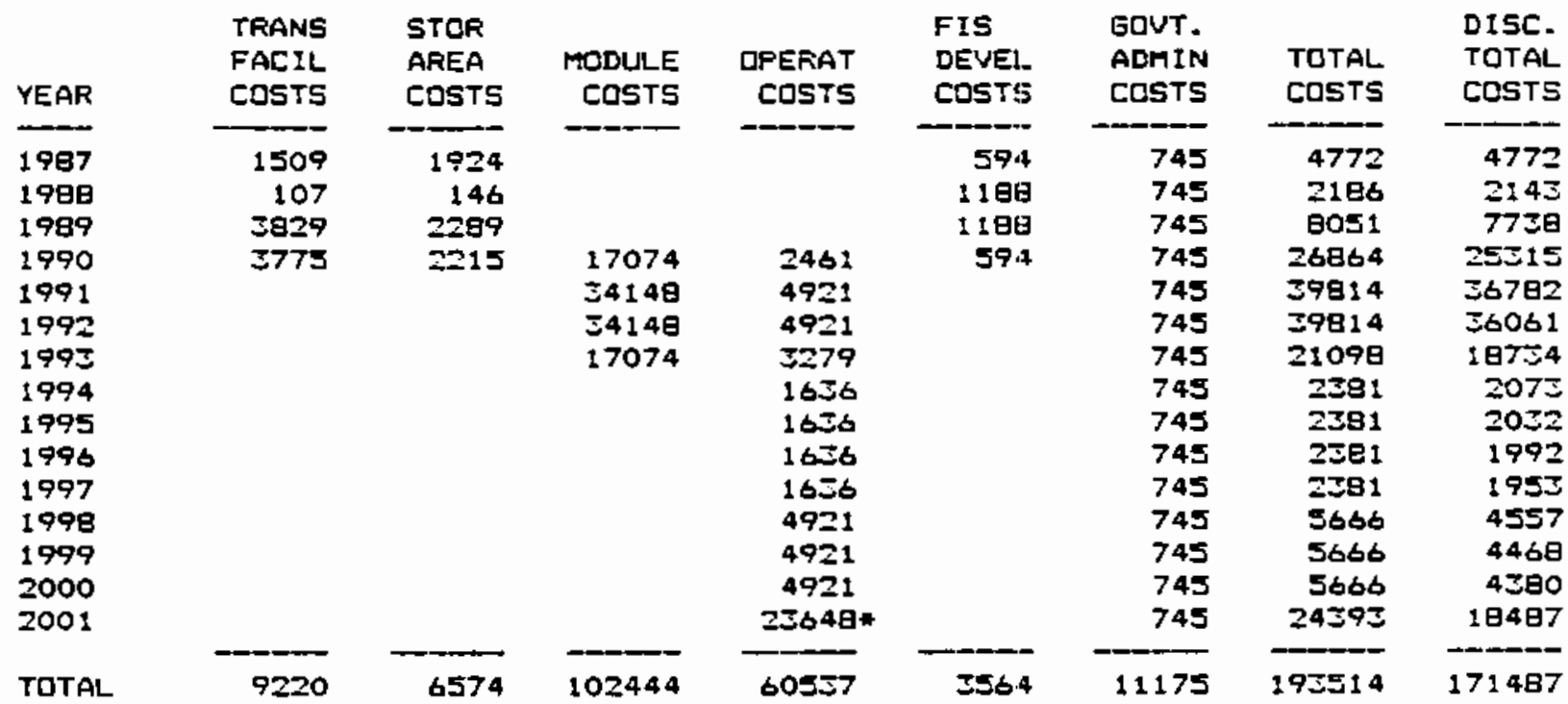

- Decommissianing cost

Initial Payment $=\theta 1 \mathrm{t} / \mathrm{Kg} \mathrm{l}$ (Includes $x 4 / \mathrm{KgU}$ impact aid)

Final Payment $=49 \mathrm{x} / \mathrm{KgU}$ (Includes $t$ f $/ \mathrm{KgU}$ impact aid)

TABLE $A 9-37$ ESTIMATED SPENDING SCHEDLLE FOR STORAGE OF 1120 SILOS (1900 MTU) AT GOVERNMENT SITE WITH EXISTING FACILITIES (ક000, 1997)

\begin{tabular}{|c|c|c|c|c|c|c|c|c|}
\hline YEAR & $\begin{array}{l}\text { TRANS } \\
\text { FACIL } \\
\text { COSTS }\end{array}$ & $\begin{array}{l}\text { STAR } \\
\text { AREA } \\
\text { COSTS }\end{array}$ & $\begin{array}{l}\text { MODULE } \\
\text { COSTS }\end{array}$ & $\begin{array}{l}\text { QPERAT } \\
\text { COSTS }\end{array}$ & $\begin{array}{l}\text { FIS } \\
\text { DEVEL } \\
\text { COSTS }\end{array}$ & $\begin{array}{l}\text { GDVT. } \\
\text { ADMIN } \\
\text { EDSTS }\end{array}$ & $\begin{array}{l}\text { IUTAL } \\
\text { COSTS }\end{array}$ & $\begin{array}{l}\text { DI5C. } \\
\text { TOTAL } \\
\text { COSTS }\end{array}$ \\
\hline 1997 & 1507 & 2001 & & & 554 & 849 & $501 \pm$ & 5013 \\
\hline 1988 & 107 & 146 & & & 1180 & 849 & 2290 & 2245 \\
\hline 1989 & 3E20 & 2743 & & & $119 \theta$ & 849 & 8609 & $8 \geq 75$ \\
\hline 1990 & $\$ 775$ & 2670 & $216=2$ & 2846 & $5 \% 4$ & 849 & I2366 & 30499 \\
\hline 1991 & & & $4=264$ & 5691 & & 949 & 49904 & 46011 \\
\hline 1992 & & & $4=264$ & 5691 & & 949 & 49804 & 45109 \\
\hline 1993 & & & 21652 & 5745 & & 849 & 26224 & 23236 \\
\hline 1994 & & & & 1795 & & 849 & 2644 & 2302 \\
\hline 1995 & & & & 1705 & & 949 & 2644 & 2257 \\
\hline 1996 & & & & 1795 & & 849 & 2344 & $2=12$ \\
\hline 1997 & & & & 1795 & & 849 & 2644 & 2169 \\
\hline 1998 & & & & 5691 & & 849 & 6540 & 5200 \\
\hline 1999 & & & & 5691 & & 849 & 6540 & 5157 \\
\hline 2000 & & & & 5691 & & 849 & 6540 & 5056 \\
\hline 2001 & & & & 29326* & & 849 & 30175 & 27869 \\
\hline TOTAL & $9=20$ & 7620 & 129792 & 71550 & $\Xi 56,4$ & 12753 & 234481 & 207720 \\
\hline
\end{tabular}

* - Decommissioning cost

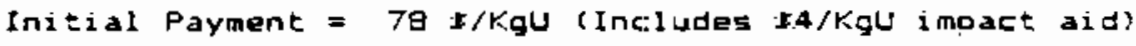

Final fayment $=465 / k g U$ (Includes $58 / k g U$ impact aid) 
10.0 SENSITIVITY OF COSTS TO CHANGES IN CONDITIONS

The sensitivity of costs for FIS to changing conditions of cost, schedule, mix of spent fuel types, and discount rate, and to whether or not the facility was subject to NRC Iicensing, was determined for the drywell at storage capacity levels of 100 MTU and 1900 MTU. The following sections describe the conditions considered and the impact of each on the total discounted cost of FIS system construction and operation and the total unit cost.

\subsection{IMPACT OF COST CHANGES}

The impact of design improvements which result in a reduction in capital cost of a new transfer facility to \$15.5-million and \$10-mitlion, and a reduction in the capital cost of modifying an existing transfer facility to $\$ 8.2$ million on FIS costs is shown in Table Al0-1.

TABLE A10-1

IMPACT OF REDUCTIONS IN CAPITAL COSTS OF TRANSFER FACILITIES

ON FIS SYSTEM COSTS

Capital Cost

(\$-Millions)

New Facility Cases

\$21. I (Base Case)

15.5

10

Change per \$-mitlion

Existing Facility Cases

9.2 (Base Case)

B.2

Change per s-million

\begin{tabular}{|c|c|}
\hline 100 & MTU \\
\hline $\begin{array}{c}\text { Total } \\
\text { Oiscounted } \\
\text { Cost }(\$ 000)\end{array}$ & $\begin{array}{c}\text { Total } \\
\text { Unit } \\
\text { Cost }(5 / \mathrm{kgU})\end{array}$ \\
\hline
\end{tabular}

\begin{tabular}{cc}
\multicolumn{1}{c}{ I900 MTU } \\
$\begin{array}{c}\text { Total } \\
\text { Oiscounted } \\
\text { Cost }(\$ 000)\end{array}$ & Cost $(\$ / \mathrm{kgU})$ \\
\hline
\end{tabular}

$\$ 60,709$

54,210

47,847

1,159

$\$ 44,383$

43,231

1,152
$\$ 646$

580

515

12

$\$ 478$

466

12
$\$ 218,096$

211,589

205,240

1,158

$\$ 199,603$

198,450

1,153
$\$ 131$

127

124

1

$\$ 121$

120

1

The estimated spending schedules, discounted annual costs, and the calculation of the Initial and Final Payments for FIS of spent fuel for each of the cases considered in Table A10-1 are set forth in Tables A10-2 through Al0-7. 
IABLE A10-2

COST SENSITIVITY CASE - \$15.5-HILLION TRANSFER FACILITY

ESTIMATED SPENDING SCHEDULE FOR STORAGE OF 2Z̈ DRYWELLS (100 MTU) AT GQVERNMENT SITE WITHOLT EXISTING FACILITIES

$(\$ 000,1997)$

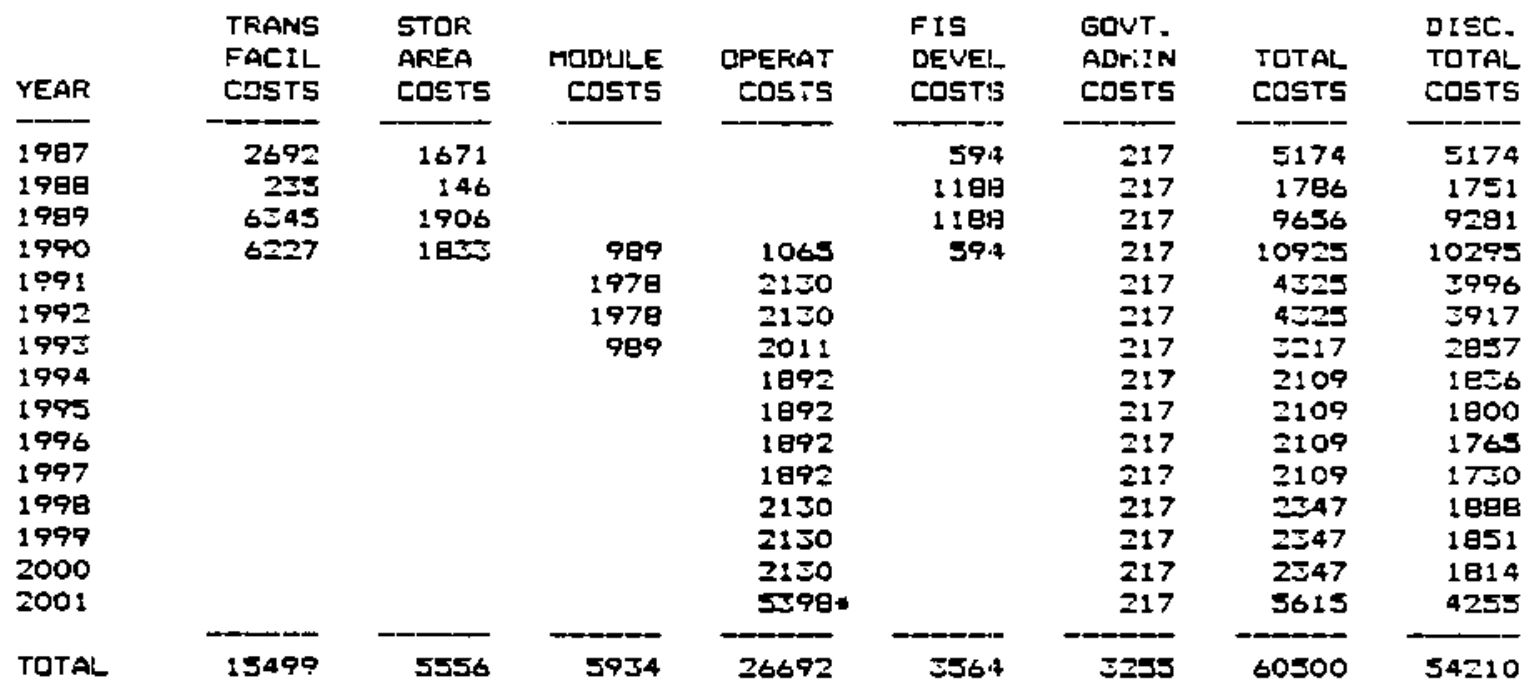

* - Decammisgioning cost

Initial Payment = 304 s/Kgl (Inizludes $55 / K g l$ impact aid)

Final Payment $=276 \pm / K g U$ (Includes $x 10 / \mathrm{KgU}$ impact aid)

TABLE A10-3

COST SEMSITIVITY CASE $\rightarrow$ SIO-MILLION TRANSFER FACILITY

ESTIMATED SFENDING SCHEDULE FOR STORAGE OF ZZD DRYWELLS (100 MTU) AT GCVERNMENT SITE WITHOUT EXISTING FACILITIES

$(15000,1987)$

\begin{tabular}{|c|c|c|c|c|c|c|c|c|}
\hline YEAR & $\begin{array}{l}\text { TRANS } \\
\text { FACIL } \\
\text { CDSTS }\end{array}$ & $\begin{array}{l}\text { STOR } \\
\text { AREA } \\
\text { COSTS }\end{array}$ & $\begin{array}{l}\text { MCDLULE } \\
\text { COSTS }\end{array}$ & $\begin{array}{r}\text { OPERAT } \\
\text { COSTS }\end{array}$ & $\begin{array}{l}\text { FIS } \\
\text { DEㄴㄷ﹎. } \\
\text { COST!S }\end{array}$ & $\begin{array}{l}\text { GoVT. } \\
\text { AOMIN } \\
\text { CasTS }\end{array}$ & $\begin{array}{l}\text { TOTAL } \\
\text { COSTS }\end{array}$ & $\begin{array}{l}\text { DISE. } \\
\text { TCTAL } \\
\text { COSTS }\end{array}$ \\
\hline 1987 & 1975 & 1671 & & & 594 & 217 & 4457 & 4457 \\
\hline $\begin{array}{l}1998 \\
1989\end{array}$ & I35 & 146 & & & 1289 & 217 & 1796 & $\begin{array}{l}1751 \\
6997\end{array}$ \\
\hline 1989 & 2953 & 1906 & & & 1183 & 217 & 7264 & 6992 \\
\hline 1990 & エ曰コこ & 1日こ二 & 989 & 1051 & 59.4 & 217 & es 19 & 8021 \\
\hline 1991 & & & 1978 & 2101 & & $=17$ & 4296 & 5969 \\
\hline 1992 & & & 1978 & 2101 & & 217 & $4 \geq 96$ & 3991 \\
\hline 1993 & & & 989 & $198=$ & & 217 & ¿189 & Zgミ1 1 \\
\hline 1994 & & & & 1863 & & $2: 7$ & 2080 & 1811 \\
\hline 1909 & & & & 1962 & & 217 & 2080 & 1775 \\
\hline 1996 & & & & 1日6: & & 217 & 2080 & 1740 \\
\hline 1997 & & & & 1863 & & $2: 7$ & 2080 & 1706 \\
\hline 1998 & & & & 2101 & & 217 & 2318 & 1864 \\
\hline 1999 & & & & 2101 & & 217 & $\approx 18$ & 1928 \\
\hline 2000 & & & & 2101 & & $=17$ & ב218 & 1792 \\
\hline 2001 & & & & $4298 *$ & & 217 & 4515 & $\$ 422$ \\
\hline TOTAL & 9998 & 5556 & 5934 & $=9289$ & 3564 & $3=55$ & 55595 & 47847 \\
\hline
\end{tabular}

* - Decommissioning cost

Initial Payment $=2515 / \mathrm{KgU}$ (Iniludes $55 / \mathrm{Kgl}$ impact aid)

Final Fayment $=264 \mathrm{~s} / \mathrm{Kgl}$ (Includos $\pm 10 / \mathrm{KgU} 1 \mathrm{mpact}$ aid) 
IABLE A.10-4

COST SENSITIVITY CASE $-\$ 15.5$-MILLION TRANSFER FACILITY

ESTIMATED SPENDING SCMEDULE FOR STORAGE OF 4478 DRYWELLS (1900 MTU) AT GOVERNMENT SITE WITHOUT EXISTING FACILITIES $(\$ 000,1987)$

\begin{tabular}{|c|c|c|c|c|c|c|c|c|}
\hline YEAR & $\begin{array}{l}\text { TRANS } \\
\text { FACIL } \\
\text { EDSTS }\end{array}$ & $\begin{array}{l}\text { STOR } \\
\text { AREA } \\
\text { COSTS }\end{array}$ & $\begin{array}{l}\text { MLDURE } \\
\text { COSTS }\end{array}$ & $\begin{array}{r}\text { DPERAT } \\
\text { CISTS }\end{array}$ & $\begin{array}{l}\text { FIS } \\
\text { DEVEL } \\
\text { COSTS }\end{array}$ & $\begin{array}{l}\text { GDVT. } \\
\text { ADMIN } \\
\text { CDSTS }\end{array}$ & $\begin{array}{l}\text { TUTAL } \\
\text { COSTS }\end{array}$ & $\begin{array}{l}\text { DISC. } \\
\text { TOTAL } \\
\text { COSTS }\end{array}$ \\
\hline $\begin{array}{l}1997 \\
1988 \\
1999 \\
1990 \\
1991 \\
1992 \\
1993 \\
1994 \\
1995 \\
1996 \\
1997 \\
1999 \\
1999 \\
2000 \\
2001\end{array}$ & $\begin{array}{r}2692 \\
2 \geq 5 \\
6=45 \\
6 \geq 77\end{array}$ & $\begin{array}{r}2008 \\
146 \\
3294 \\
3221\end{array}$ & $\begin{array}{l}18770 \\
57541 \\
57541 \\
18770\end{array}$ & $\begin{array}{c}3704 \\
7400 \\
7409 \\
5277 \\
\$ 146 \\
\$ 146 \\
3146 \\
3146 \\
7408 \\
7408 \\
7409 \\
27374 *\end{array}$ & $\begin{array}{r}594 \\
1186 \\
1189 \\
594\end{array}$ & $\begin{array}{l}649 \\
949 \\
849 \\
949 \\
949 \\
849 \\
849 \\
849 \\
849 \\
949 \\
649 \\
849 \\
849 \\
849 \\
849\end{array}$ & $\begin{array}{r}6273 \\
2411 \\
11676 \\
7 \pm 565 \\
45798 \\
43798 \\
24996 \\
3995 \\
3995 \\
3995 \\
3995 \\
8257 \\
8257 \\
9257 \\
28203\end{array}$ & 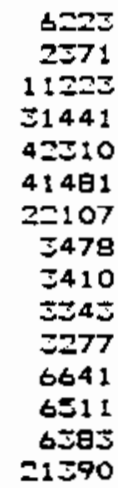 \\
\hline TOTAL & 15499 & 8749 & 112622 & 85979 & 3564 & 12735 & 259148 & 211589 \\
\hline
\end{tabular}

* Decomaissianing cost

Initial Payment $=74 \mathrm{~s} / \mathrm{KqU}$ (Includes $\$ 4 / \mathrm{kgl}$ iapact aid)

Final Fayment $\Rightarrow$ SI $x / K q U$ (Ineludes sB/KgU impact aid)

TABLE A10-5

COST SENSITIYITY CASE -- \$10-MILLION TRANSFER FACILITY

ESTIMATED SPENDING SCHEDULE FOR STORAGE OF $447 B$ DRYWELLS ( $1900 \mathrm{MTU})$

AT GOVERNMENT S!TE WITHOUT EXISTING FACILITIES $(\$ 000,1987)$

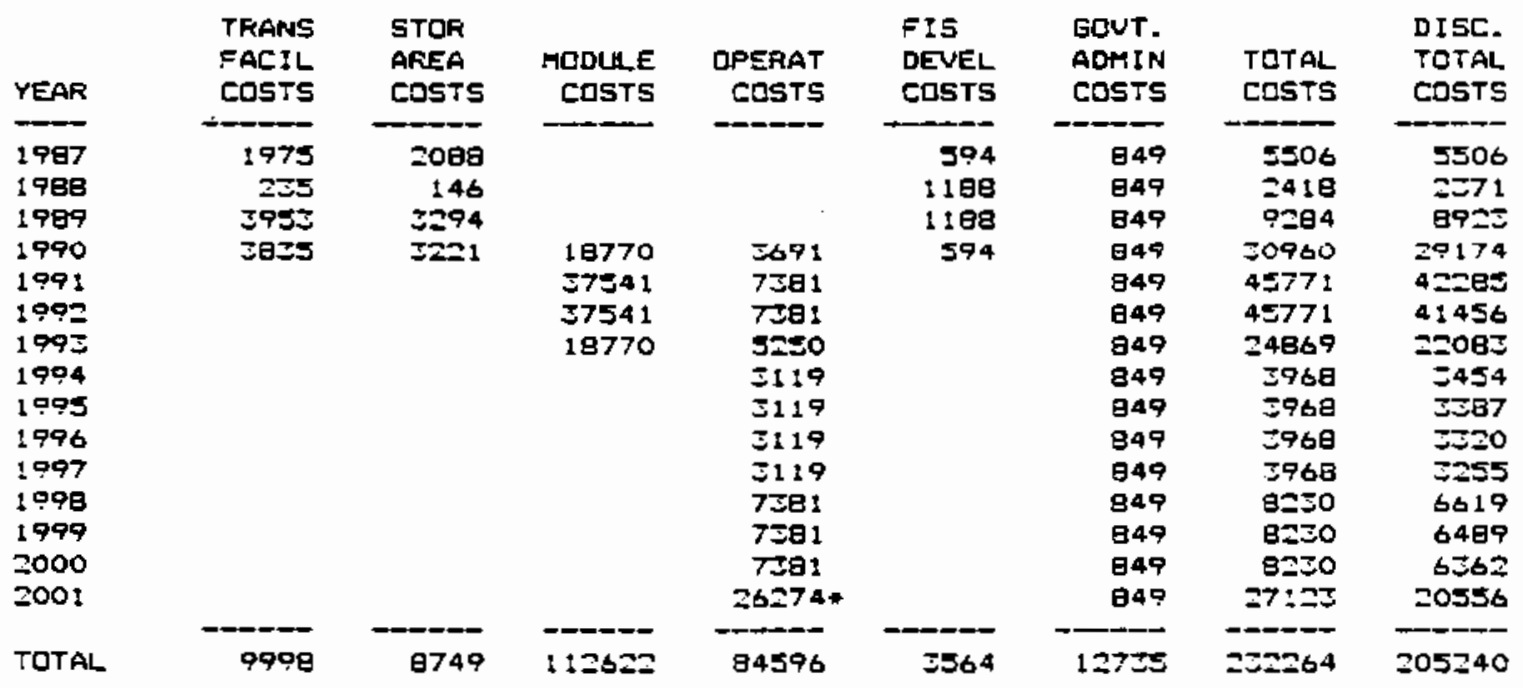

* - Decammi isioning cost

\footnotetext{
Initial Payment $=71$ \&/KgU (Includes $54 / k g$ d impact aid)

Final Payment $\Rightarrow 5 J \mathrm{I} /$ KgU (Includes \#B/KgL impact aid)
} 
TABLE A10-6

COST SENSITIVITY CASE -- SB.2-MILLIOM TRANSEER FACILITY ESTIMATED SFENDING SCHEDULE FOR STRRAGE OF Z:S DRYWELLS ( 100 הTU) AT GDVERNMENT SITE WITH EXISTING FACILITIES (s000,:997)

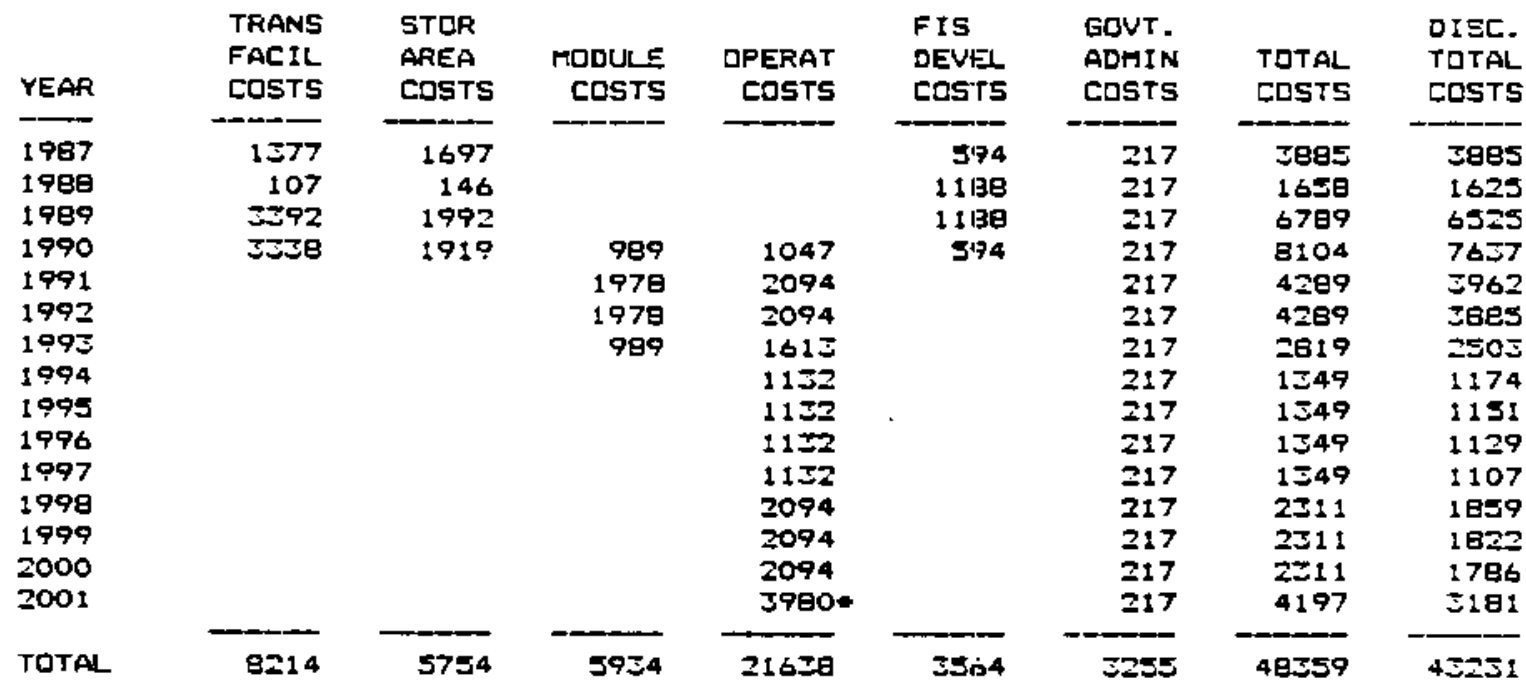

- Decomaissianing cost

Initial Paymorit = 25s s/Kgl (Ineludes IS/Kgl impact aid)

Final fayment $=2 \sum 1$ s/Kgl (Intiludes $\$ 10 / \mathrm{Kgl}$ impact aid)

TABLE A10-7

COST SENSITIVITY CASE - \$8.2-RILLION TRANSFER FACILITY ESTIMATED SPENDING SCHEDULE FOR STORAGE OF 4479 DRYWELLS (I900 MTU) AT GQVERNMENT SITE WITH EXISTIMG FACILITIES $(\mp 000,1997)$

\begin{tabular}{|c|c|c|c|c|c|c|c|c|}
\hline YEAR & $\begin{array}{l}\text { TRANS } \\
\text { FACIL } \\
\text { COSTS }\end{array}$ & $\begin{array}{l}\text { STDR } \\
\text { AFEA } \\
\text { COSTS }\end{array}$ & $\begin{array}{l}\text { MCDLLE } \\
\text { COSTS }\end{array}$ & $\begin{array}{r}\text { QPERAT } \\
\text { COSTS }\end{array}$ & $\begin{array}{l}\text { FIS } \\
\text { DEVER } \\
\text { CDSTS }\end{array}$ & $\begin{array}{l}\text { GOUT. } \\
\text { ADrIN } \\
\text { CostS }\end{array}$ & $\begin{array}{l}\text { TUTAL } \\
\text { COSTS }\end{array}$ & $\begin{array}{l}\text { DISE. } \\
\text { TOTAL } \\
\text { CDSTS }\end{array}$ \\
\hline $\begin{array}{l}1987 \\
1980\end{array}$ & $\begin{array}{r}1377 \\
107\end{array}$ & $\begin{array}{r}2115 \\
146\end{array}$ & & & $\begin{array}{r}594 \\
1198\end{array}$ & $\begin{array}{l}849 \\
949\end{array}$ & $\begin{array}{l}495= \\
2790\end{array}$ & $\begin{array}{l}4933 \\
2243\end{array}$ \\
\hline 1989 & I592 & 379 & & & 1180 & 849 & 9808 & 8466 \\
\hline 1990 & 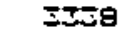 & $=06$ & 18770 & उ०8日 & 594 & 849 & 30545 & 28783 \\
\hline 1991 & & & 57541 & 7575 & & 949 & 45765 & 42280 \\
\hline 1992 & & & 57541 & 7575 & & 849 & 45765 & 41451 \\
\hline 1995 & & & 19770 & 4597 & & 849 & 24216 & 21503 \\
\hline 1994 & & & & 1818 & & 849 & 2667 & $2=2$ \\
\hline 1995 & & & & 1818 & & 849 & 2667 & $2 \geq 76$ \\
\hline 1996 & & & & 1919 & & 849 & 2ø67 & ב בבת \\
\hline 1997 & & & & 1810 & & 849 & 2667 & 2198 \\
\hline 1999 & & & & $7 \equiv 75$ & & 849 & $8=24$ & 6614 \\
\hline 1990 & & & & 7275 & & 849 & 8224 & 64ES \\
\hline 2000 & & & & 7 シ5 & & 849 & $9=24$ & 4357 \\
\hline 2001 & & & & 25956 & & 849 & 26905 & $20 \Xi 15$ \\
\hline TOTAL & 9214 & 9944 & 112622 & 7вะ日日 & $\operatorname{Ts} 44$ & 12735 & 224467 & 190450 \\
\hline
\end{tabular}

* - Decammissioning cost

\footnotetext{
Initial Fayment $=70 \mathrm{~s} / \mathrm{KgU}$ (Includes $54 / \mathrm{KgU}$ impact aid)

Final Fayment $=$ so $x / K g U$ (Includes ta/kgu impact aid)
} 
The impact of reductions in the cost of individual modules (drywells) and canisters on FIS costs is shown in Table A10-8.

TABLE A10-8

IMPACT OF REDUCTIONS IN COST OF DRYWELLS AND CANISTERS

ON FIS SYSTEM COSTS

\begin{tabular}{|c|c|c|c|c|}
\hline \multirow[b]{2}{*}{ Item $\cos t(\$)$} & \multicolumn{2}{|c|}{$100 \mathrm{MTU}$} & \multicolumn{2}{|c|}{$1900 \mathrm{MTU}$} \\
\hline & $\begin{array}{c}\text { Total } \\
\text { Oiscounted } \\
\text { Cost }(\$ 000) \\
\end{array}$ & $\begin{array}{c}\text { Total } \\
\text { Unit } \\
\text { Cost }(\$ / \mathrm{kgU}) \\
\end{array}$ & $\begin{array}{c}\text { Total } \\
\text { Discounted } \\
\text { Cost }(\$ 000) \\
\end{array}$ & $\begin{array}{c}\text { Totai } \\
\text { Unit } \\
\text { Cost }(\$ / \mathrm{kgU}) \\
\end{array}$ \\
\hline \multicolumn{5}{|l|}{ Drywells } \\
\hline$\$ 20,609$ & $\$ 60,709$ & $\$ 646$ & $\$ 218,096$ & $\$ 131$ \\
\hline 15,000 & 59,236 & 631 & 190,146 & 115 \\
\hline 10,000 & 57,923 & 618 & 165,230 & 100 \\
\hline Change per \$-thousand & 263 & 3 & 4,983 & 3 \\
\hline \multicolumn{5}{|l|}{ Canisters } \\
\hline$\$ 4,541$ & $\$ 60,709$ & $\$ 646$ & $\$ 218,096$ & $\$ 131$ \\
\hline 3,500 & 60,449 & 644 & 213,123 & 128 \\
\hline 2,000 & 60,072 & 639 & 205,960 & 124 \\
\hline Change per $\$$-thousand & 251 & 3 & 4,776 & 3 \\
\hline
\end{tabular}

The estimated spending schedules, discounted annual costs, and the calculation of the Initial and Final Payments for FIS of spent fuel for each of the cases considered in Table A10-8 are set forth in Tabies A10-9 through Al0-16. 
TABLE A10-9

COST SENSITIVITY CASE -- \$15,000 DRYWELL

ESTIMATED SFFNDING SCHEDULE FUR STORAGE DF 2:D DRYWELLS (100 RTU) AT GOVERNMENT $5 I T E$ WITHOUT EXISTING FACILITIES

$(9000,1997)$

\begin{tabular}{|c|c|c|c|c|c|c|c|c|}
\hline YEAR & $\begin{array}{l}\text { TRANS } \\
\text { FACIL } \\
\text { CUSTS }\end{array}$ & $\begin{array}{l}\text { STQK } \\
\text { AREA } \\
\text { COSTS }\end{array}$ & $\begin{array}{r}\text { MODULE } \\
\text { COSTS }\end{array}$ & $\begin{array}{l}\text { OPERAT } \\
\text { EOSTS }\end{array}$ & $\begin{array}{l}\text { FIS } \\
\text { DEUËL } \\
\text { CUSTS }\end{array}$ & $\begin{array}{l}\text { GOUT. } \\
\text { ADMIN } \\
\text { COSTS }\end{array}$ & $\begin{array}{l}\text { TLTAL } \\
\text { COSTS }\end{array}$ & $\begin{array}{l}\text { DISC. } \\
\text { TETAL } \\
\text { CESTS }\end{array}$ \\
\hline $\begin{array}{l}1997 \\
1989 \\
1999 \\
1990 \\
1991 \\
1992 \\
1993 \\
1994 \\
1995 \\
1996 \\
1997 \\
1998 \\
1999 \\
2000 \\
2001\end{array}$ & $\begin{array}{r}3476 \\
235 \\
8790 \\
8672\end{array}$ & $\begin{array}{r}1671 \\
146 \\
1906 \\
18 \Xi 2\end{array}$ & $\begin{array}{r}767 \\
1577 \\
1537 \\
769\end{array}$ & $\begin{array}{l}1076 \\
2152 \\
2152 \\
2032 \\
1914 \\
1914 \\
1914 \\
1914 \\
2152 \\
2152 \\
2152 \\
6250\end{array}$ & $\begin{array}{r}594 \\
1189 \\
1198 \\
594\end{array}$ & $\begin{array}{l}217 \\
217 \\
217 \\
217 \\
217 \\
217 \\
217 \\
=17 \\
217 \\
217 \\
217 \\
217 \\
217 \\
217 \\
217\end{array}$ & $\begin{array}{r}5908 \\
1706 \\
1=101 \\
13161 \\
5906 \\
5906 \\
5019 \\
2151 \\
7131 \\
=151 \\
2131 \\
3569 \\
2369 \\
2569 \\
6475\end{array}$ & $\begin{array}{r}5908 \\
1751 \\
11651 \\
12402 \\
5609 \\
5550 \\
2681 \\
1855 \\
1919 \\
1782 \\
1748 \\
1905 \\
1868 \\
1851 \\
4907\end{array}$ \\
\hline TOTAL & $2112 \Xi$ & 5556 & 4612 & 27783 & 3564 & ב25 & $4589=$ & 5 \\
\hline
\end{tabular}

* - Decommissianing cost

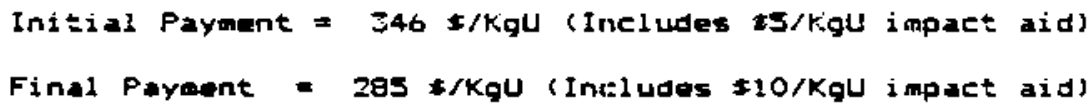

TABLE A $10-10$

COST SEASITIVITY CASE $-\$ 10,000$ DRYWELL

ESTIMATED SPENDING SCHEDULE FLR STCRAGE OF ZTS DRYWELLS (100 RTU) AT GLVERNUENT SITE WITHOUT EXISTING FACILITIES

(\$000, 1997)

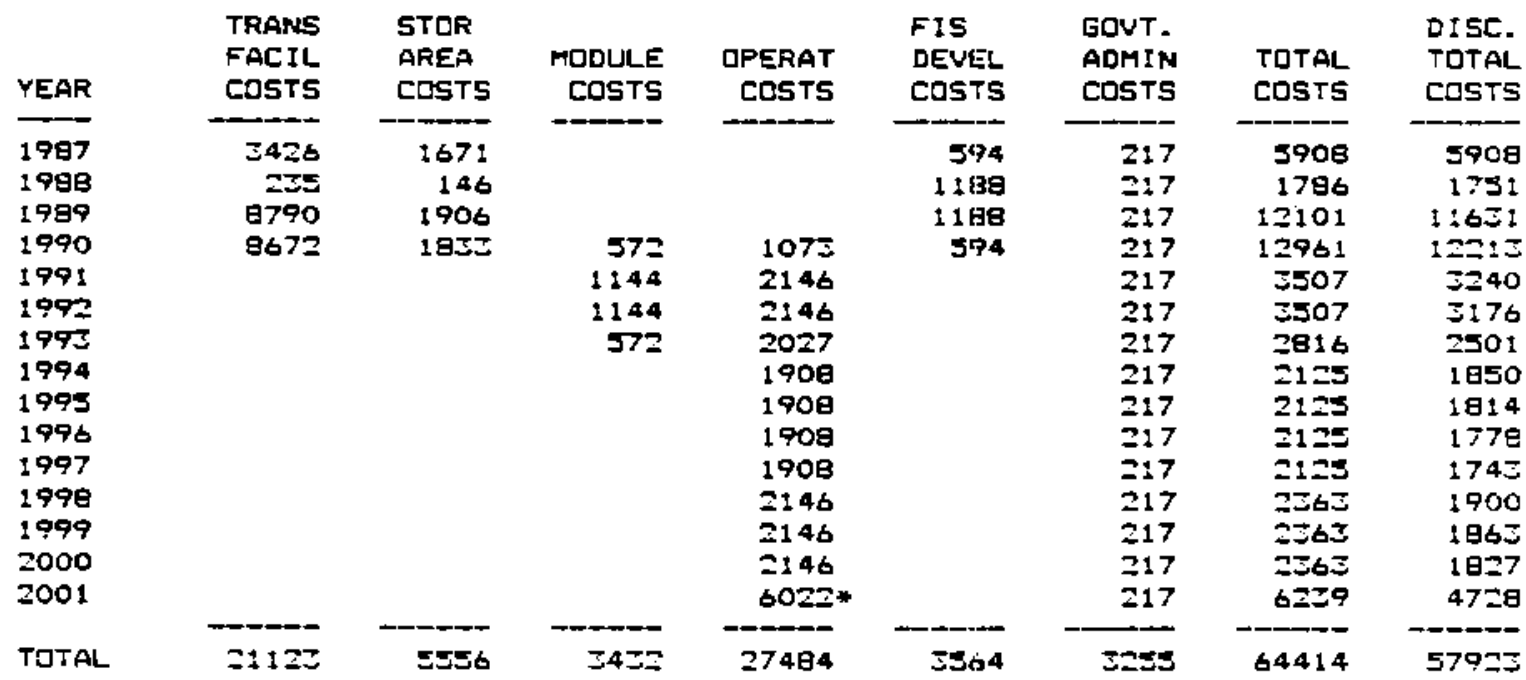

* - Decommissioning cost 
TABLE A10-11

COST SENSITIVITY CASE - \$15,000 DRYUELL

SSTIMATED SPENDING SCHEDULE FOR STLFAGE DF 4479 DRYWEILLS (1900 HTU) AT GOVEFNMENT SITE WITHOUT EXISTING FACILITIES

(5000,1987)

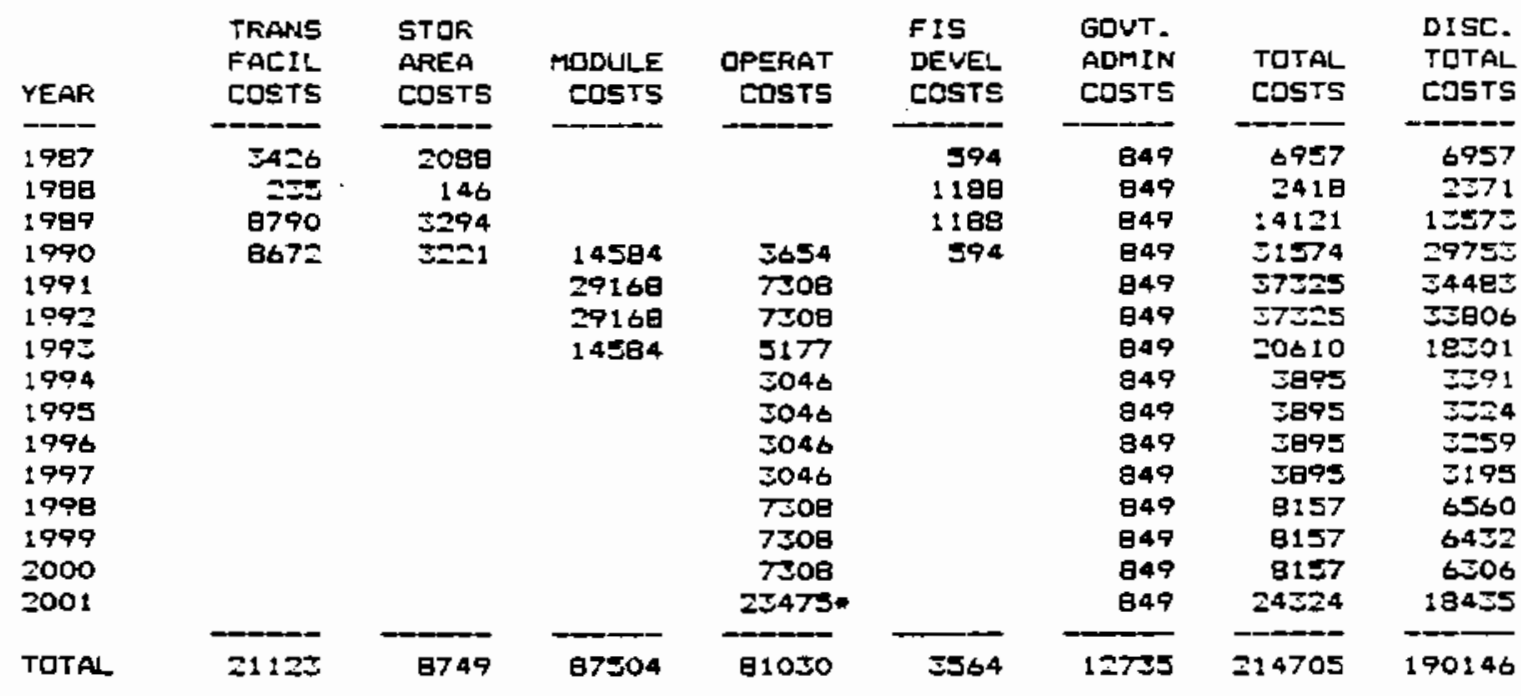

* - Decommissianing cost

Initial Payment $=65 \mathrm{t} / \mathrm{KgU}$ (Includes $t 4 / \mathrm{KgU}$ inpact aid)

Final Payment = so $x / \mathrm{Kgl}$ (Includes t7/Kgl impact aid)

TABLE A10-12

COST SENSITIVITY CASE -- S10,000 DRYUELL

ESTIMATED SPENDING SCHEDUE FOR STORAGE OF 4478 DRYWELLS (1900 MTU) AT GOVERNMENT SITE WITHOUT EXISTING FACILITIES

$(\$ 000,1987)$

\begin{tabular}{|c|c|c|c|c|c|c|c|c|}
\hline YEAR & $\begin{array}{l}\text { TRANS } \\
\text { FACIL } \\
\text { COSTS }\end{array}$ & $\begin{array}{l}\text { STOR } \\
\text { AREA } \\
\text { COSTS }\end{array}$ & $\begin{array}{l}\text { MODULE } \\
\text { COSTS }\end{array}$ & $\begin{array}{r}\text { OPERAT } \\
\text { COSTS }\end{array}$ & $\begin{array}{l}\text { F IS } \\
\text { DEVEL } \\
\text { COSTS }\end{array}$ & $\begin{array}{l}\text { GOVT. } \\
\text { ADMIN } \\
\text { COSTS }\end{array}$ & $\begin{array}{l}\text { TOTAL } \\
\text { COSTS }\end{array}$ & $\begin{array}{l}\text { DISC. } \\
\text { TUTAL } \\
\text { CUSTS }\end{array}$ \\
\hline $\begin{array}{l}1987 \\
1998 \\
1999 \\
1990 \\
1991 \\
1992 \\
1995 \\
1994 \\
1995 \\
1996 \\
1997 \\
1990 \\
1999 \\
2000 \\
2001\end{array}$ & $\begin{array}{r}5420 \\
253 \\
8790 \\
8672\end{array}$ & $\begin{array}{r}2088 \\
146 \\
=294 \\
3271\end{array}$ & $\begin{array}{l}10052 \\
21705 \\
21705 \\
10852\end{array}$ & $\begin{array}{c}3390 \\
7192 \\
7192 \\
5061 \\
3930 \\
2930 \\
2930 \\
2930 \\
7192 \\
7192 \\
7192 \\
19997 *\end{array}$ & $\begin{array}{r}594 \\
1189 \\
1189 \\
594\end{array}$ & $\begin{array}{l}849 \\
849 \\
949 \\
849 \\
949 \\
849 \\
849 \\
849 \\
849 \\
949 \\
849 \\
849 \\
849 \\
849 \\
849\end{array}$ & $\begin{array}{r}6957 \\
2419 \\
14121 \\
27784 \\
29746 \\
29746 \\
16762 \\
5779 \\
5779 \\
5770 \\
5779 \\
8041 \\
8041 \\
8041 \\
19946\end{array}$ & 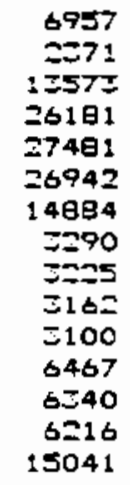 \\
\hline TOTAL & 21123 & 8749 & 65114 & 75:54 & 3564 & 12755 & 186619 & 165230 \\
\hline
\end{tabular}

- Decommissianing cost

\footnotetext{
Initial Payment $=5 J / K g U$ (Inciudes $s J / K g U$ impact aid)

Final Fayment $=47$ \& Kgl (Includes $5.6 / k g l$ impact aid)
} 
TABLE A10-13

COST SENSITIVITY CASE \$3,500 CANISTER

ESTIMATED SPENDING SCHEDULE FDR STORAGE OF 236 ORYWELLS ( 100 MTU) AT GCVERNIENT SITE WITHOUT EXISTING FACILITIES $(* 000,1987)$

\begin{tabular}{|c|c|c|c|c|c|c|c|c|}
\hline YEAR & $\begin{array}{l}\text { TRANS } \\
\text { FACIL } \\
\text { COSTS }\end{array}$ & $\begin{array}{l}\text { STOR } \\
\text { AREA } \\
\text { COSTS }\end{array}$ & $\begin{array}{l}\text { RODULE } \\
\text { COSTS }\end{array}$ & $\begin{array}{r}\text { OPERAT } \\
\text { COSTS }\end{array}$ & $\begin{array}{l}\text { FIS } \\
\text { DEVEL } \\
\text { COSTS }\end{array}$ & $\begin{array}{l}\text { GOVT. } \\
\text { ADMIN } \\
\text { COSTS }\end{array}$ & $\begin{array}{l}\text { TOTAL } \\
\text { COSTS }\end{array}$ & $\begin{array}{l}\text { DISC. } \\
\text { TOTAL } \\
\text { COSTS }\end{array}$ \\
\hline $\begin{array}{l}1967 \\
1998 \\
1989 \\
1990 \\
1991 \\
1992 \\
1992 \\
1994 \\
1995 \\
1996 \\
1997 \\
1990 \\
1999 \\
2000 \\
2001\end{array}$ & $\begin{array}{r}5426 \\
235 \\
8790 \\
9672\end{array}$ & $\begin{array}{r}1671 \\
146 \\
1906 \\
1859\end{array}$ & $\begin{array}{r}948 \\
1897 \\
1997 \\
948\end{array}$ & $\begin{array}{l}1000 \\
2159 \\
2159 \\
2040 \\
1921 \\
1921 \\
1921 \\
1921 \\
2159 \\
2159 \\
2159 \\
6474\end{array}$ & $\begin{array}{r}594 \\
1180 \\
1188 \\
594\end{array}$ & $\begin{array}{l}217 \\
217 \\
217 \\
=17 \\
217 \\
217 \\
217 \\
217 \\
=17 \\
217 \\
217 \\
217 \\
217 \\
217 \\
217\end{array}$ & 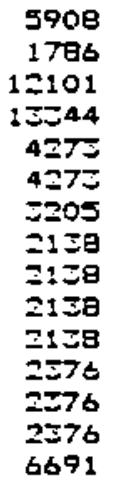 & $\begin{array}{r}5909 \\
1751 \\
11451 \\
12574 \\
3948 \\
5870 \\
2946 \\
1961 \\
1825 \\
1799 \\
1754 \\
1911 \\
1975 \\
1057 \\
3071\end{array}$ \\
\hline TOTAL & $211=3$ & 5556 & 5690 & 29073 & 3564 & 3בS5 & $67=61$ & 60449 \\
\hline
\end{tabular}

* - Decammissioning cost

Initial payment = 56 f/Kqu (Includes $55 / \mathrm{Kgl}$ impact aid)

Final Payment * 298 \$ Kgu (Includes $t 10 / \mathrm{KgU}$ impact aid)

TABLE A10-14

COST SENSITIVITY CASE -- \$2,000 CANISTER

ESTIMATED SPENDING SCHEDLUE FOR STORAGE OF 25 DRYWELIS (100 RTU) AT GOVEFNHENT SITE WITHOUT EXISTING FACILITIES

(s.000, 1987)

\begin{tabular}{|c|c|c|c|c|c|c|c|c|}
\hline YEAR & $\begin{array}{l}\text { TRANS } \\
\text { FACIL } \\
\text { COSTS }\end{array}$ & $\begin{array}{l}\text { STOK } \\
\text { AREA } \\
\text { COSTS }\end{array}$ & $\begin{array}{l}\text { TDDULE } \\
\text { COSTS }\end{array}$ & $\begin{array}{r}\text { OPERAT } \\
\text { COSTS }\end{array}$ & $\begin{array}{l}\text { FIS } \\
\text { DEVEI } \\
\text { COSTS }\end{array}$ & $\begin{array}{l}\text { GOUT. } \\
\text { ADMIN } \\
\text { COSTS }\end{array}$ & $\begin{array}{l}\text { TDTAL } \\
\text { COSTS }\end{array}$ & $\begin{array}{l}\text { DISC. } \\
\text { TOTAL } \\
\text { COSTS }\end{array}$ \\
\hline $\begin{array}{l}1987 \\
1998\end{array}$ & $\begin{array}{r}3426 \\
2 \geq 5\end{array}$ & $\begin{array}{r}1671 \\
146\end{array}$ & & & $\begin{array}{r}554 \\
1189\end{array}$ & $\begin{array}{l}217 \\
217\end{array}$ & $\begin{array}{l}5908 \\
1796\end{array}$ & $\begin{array}{l}3908 \\
1751\end{array}$ \\
\hline 1989 & 8790 & 1906 & & & 1128 & $2: 7$ & 12101 & $116=1$ \\
\hline 1990 & 0672 & $18 \Xi 5$ & 899 & 1080 & 594 & 217 & 15795 & 12519 \\
\hline 1991 & & & 1779 & 2159 & & 217 & 4155 & 3959 \\
\hline 1992 & & & 1779 & 2159 & & $2: 7$ & 4155 & $576 \Xi$ \\
\hline 1983 & & & 989 & 2040 & & $2: 7$ & 3146 & 2794 \\
\hline 1994 & & & & 1921 & & 217 & 2138 & 1日s \\
\hline 1993 & & & & 1921 & & 217 & $21 \approx 8$ & $19=5$ \\
\hline 1996 & & & & $19 \geq 1$ & & 217 & 2138 & 1799 \\
\hline 1997 & & & & 1971 & & 217 & 2138 & 1754 \\
\hline 1998 & & & & 2159 & & $2 ! 7$ & 2376 & 1911 \\
\hline 1999 & & & & 2159 & & 217 & 2576 & 1973 \\
\hline 2000 & & & & 2159 & & $2: 7$ & $2=76$ & 1837 \\
\hline 2001 & & & & $6402 *$ & & 217 & 6620 & 5017 \\
\hline TOTAL & כ1 & 5556 & $5=6$ & 29002 & 3544 & 3755 & ot日 $\Delta$ & 60073 \\
\hline
\end{tabular}

- - Decammissianing fost

\footnotetext{
Initial Payment = $3525 / \mathrm{Kg} U$ (Includes $55 / \mathrm{Kgl}$ impact aid)

Final Payment $=287$ /Kgl (Includes $\$ 10 / \mathrm{kgU}$ impact aid)
} 
TABLE AI0-15

COST SENSITIVITY CASE \$3,500 CANISTER

ESTIMATED SPENDING SCHEDULE FOF STOFAGE OF 4479 DRYWELLS ( 1900 RTU) AT GOVERMMENT SITE WITHOLT EXISTING FACILITIES ( $\$ 000,1997$ )

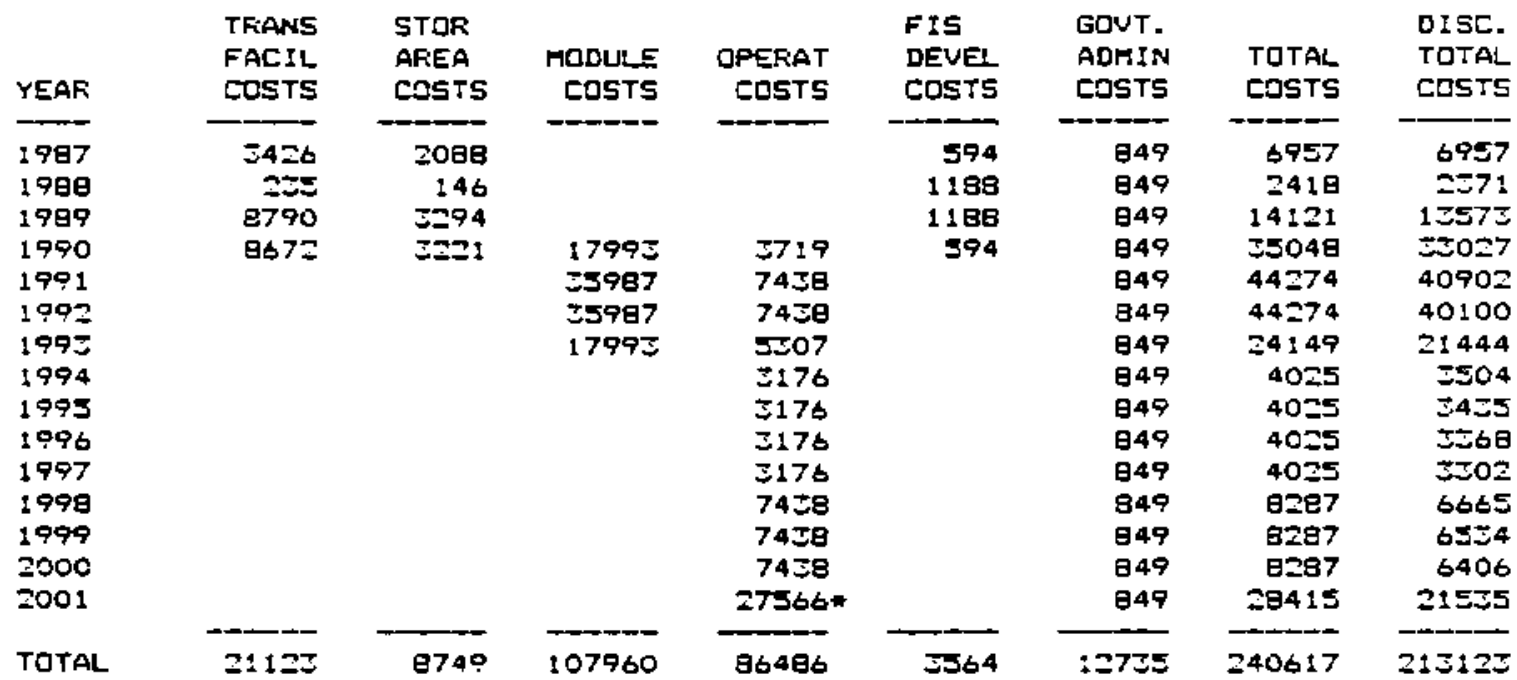

- Decommissioning cost

Initial Paymant $=74 \mathrm{~s} / \mathrm{kgU}$ (Includes $54 / \mathrm{KgU}$ impact aid)

Final Paymant * $34 \mathrm{~s} / \mathrm{KgU}$ (Ineludas fo/KgU impact aid)

TABLE A10-16

COST SENSITIVITY CASE -- \$2,000 CANISTER

ESTIMATED SPENDING SCHEDULE FOR STORAGE OF 4479 DRYWELS ( 1900 MTU) AT GOVERMNENT SITE WITHUUT EXISTING FACILITIES $(5000,1997)$

\begin{tabular}{|c|c|c|c|c|c|c|c|c|}
\hline YEAR & $\begin{array}{l}\text { TRANS } \\
\text { FACIL } \\
\text { COSTS }\end{array}$ & $\begin{array}{l}\text { STOR } \\
\text { AREA } \\
\text { COSTS }\end{array}$ & $\begin{array}{r}\text { MODULE } \\
\text { EOSTS }\end{array}$ & $\begin{array}{l}\text { OPERAT } \\
\text { EDSTS }\end{array}$ & $\begin{array}{l}\text { F IS } \\
\text { DEVEL } \\
\text { CDSTS }\end{array}$ & $\begin{array}{l}\text { GDVT. } \\
\text { ADMIN } \\
\text { COSTS }\end{array}$ & $\begin{array}{l}\text { TOTAL } \\
\text { COSTS }\end{array}$ & $\begin{array}{l}\text { DISC. } \\
\text { TETAL } \\
\text { COSTS }\end{array}$ \\
\hline $\begin{array}{l}1987 \\
1998 \\
1999\end{array}$ & $\begin{array}{r}3426 \\
250 \\
0790\end{array}$ & $\begin{array}{r}2006 \\
146 \\
5294\end{array}$ & & & $\begin{array}{r}594 \\
1189 \\
1198\end{array}$ & $\begin{array}{l}849 \\
049 \\
049\end{array}$ & $\begin{array}{r}6957 \\
2419 \\
14121\end{array}$ & $\begin{array}{r}6957 \\
2571 \\
15575\end{array}$ \\
\hline $\begin{array}{l}1990 \\
1991 \\
1007\end{array}$ & 0672 & 3221 & $\begin{array}{l}16874 \\
33748\end{array}$ & $\begin{array}{l}3719 \\
7430\end{array}$ & 594 & $\begin{array}{l}949 \\
149 \\
049\end{array}$ & $\begin{array}{l}53929 \\
42035 \\
47035\end{array}$ & $\begin{array}{l}51972 \\
59834 \\
=9077\end{array}$ \\
\hline $\begin{array}{l}1992 \\
1992 \\
1994\end{array}$ & & & $\begin{array}{l}5780 \\
16874\end{array}$ & $\begin{array}{l}74 \pm 8 \\
5307 \\
-174\end{array}$ & & $\begin{array}{l}949 \\
949\end{array}$ & $\begin{array}{l}42035 \\
=23030\end{array}$ & $\begin{array}{r}30072 \\
20450 \\
5504\end{array}$ \\
\hline $\begin{array}{l}1494 \\
1995\end{array}$ & & & & 3176 & & $\begin{array}{l}849 \\
849\end{array}$ & $40=3$ & $\begin{array}{l}3504 \\
34=5\end{array}$ \\
\hline 1996 & & & & 5176 & & 849 & 4025 & $=0$ \\
\hline 1997 & & & & $\$ 176$ & & 849 & 4023 & $\approx=0$ \\
\hline 1998 & & & & $743 \mathrm{~B}$ & & $64 \%$ & e297 & 6665 \\
\hline 1999 & & & & 7438 & & 849 & 0297 & 653 \\
\hline 2000 & & & & $74 \Xi 9$ & & 949 & 8297 & 6406 \\
\hline 2001 & & & & $262=3$ & & 849 & 27072 & 2051 \\
\hline TOTAL & 21120 & 8749 & 101244 & 85143 & 3564 & 12735 & בこ558 & 205960 \\
\hline
\end{tabular}

* Decommissioning east

\footnotetext{
Initial fayment $=71 \mathrm{~s} / \mathrm{kqU}$ (Includes $\mathrm{s} / \mathrm{kg} \mathrm{K}$ impact aid)

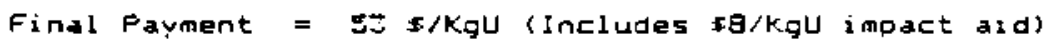


10.2 IMPACT OF SCHEDULE CHANGES

The impact on FIS costs of extending the FIS program by 2 years and by 5 years as a result of a delay in repository startup is shown in Table Al0-17.

TABLE A10-17

IMPACT OF EXTENDING THE TERM OF THE FIS PROGRAM

ON FIS SYSTEM COSTS

Year of
Completion of
Fis Activities
New Transfer Facility Cases
2000 (Base Case)
2002
2005
Increase-per yr. of delay
Existing Transfer Facility
Cases
2000 (Base Case)
2002
2005
Increase-per yr. of delay

Year of

Completion of

Fis Activities

Wransfer facility Cases

2000 (Base Case)

2002

(ncrease-per yr. of delay

\begin{tabular}{|c|c|}
\hline $\begin{array}{c}\text { Tota) } \\
\text { Discounted } \\
\text { ost }(\$ 000)\end{array}$ & $\begin{array}{c}\text { Tota } \\
\text { Unit } \\
\operatorname{cost}(\$ / \mathrm{kgU})\end{array}$ \\
\hline
\end{tabular}

\begin{tabular}{cc}
$\frac{1900 \mathrm{MTU}}{\text { Total }}$ & Total \\
Discounted & Unit \\
Cost $(\$ 000)$ & Cost $(\$ / \mathrm{kgU})$ \\
\hline
\end{tabular}

$$
\$ 60,709
$$

63,699

67.967

1,452

$\$ 646$

679

725

16
$\$ 218,096$
222,882
229,714
2,324

$\$ 131$

135

139

2

$\begin{array}{rr}544,383 & \$ 478 \\ 46,196 & 497 \\ 48,784 & 526 \\ 880 & 10\end{array}$
$\$ 199,603$
202,309
206,171
1,314

$\$ 121$

The estimated spending schedules, discounted annual costs, and the calculation of the Initial and Final payments for FIS of spent fuel for each of the cases considered in Table Al0-17 are set forth in Tables AlO-18 through A10-25. 
TABLE A10-18

COST SEISITIVITY CASE - 2 YEAR EXTENSION OF FIS PROGRAM

ESTIMATED SPENDING SEHEDULE FCR STORAGE OF ZSG DRYWELLS (100 MTU) AT GOVERNMENT SITE WITMQUT EXISTING FACILITIES

$(\$ 000,19 \mathrm{e7})$

\begin{tabular}{|c|c|c|c|c|c|c|c|c|}
\hline YEAR & $\begin{array}{l}\text { TRANS } \\
\text { FACIL } \\
\text { COSTS }\end{array}$ & $\begin{array}{l}\text { STOR } \\
\text { AREA } \\
\text { COSTS }\end{array}$ & $\begin{array}{l}\text { MODLLE } \\
\text { COSTS }\end{array}$ & $\begin{array}{r}\text { DPGRAT } \\
\text { COSTS }\end{array}$ & $\begin{array}{l}\text { FIS } \\
\text { DEVER } \\
\text { COSTS }\end{array}$ & $\begin{array}{l}\text { GOVT, } \\
\text { ADMIN } \\
\text { CDSTS }\end{array}$ & $\begin{array}{l}\text { TOTAL } \\
\text { COSTS }\end{array}$ & $\begin{array}{l}\text { DISC. } \\
\text { TOTAL } \\
\text { COETS }\end{array}$ \\
\hline $\begin{array}{l}1997 \\
1998 \\
1999 \\
1990 \\
1991 \\
1992 \\
1993 \\
1994 \\
1995 \\
1996 \\
1997 \\
1998 \\
1999 \\
2000 \\
2001 \\
2002 \\
2003\end{array}$ & $\begin{array}{r}3426 \\
235 \\
8790 \\
8672\end{array}$ & $\begin{array}{r}1671 \\
146 \\
1906 \\
1973\end{array}$ & $\begin{array}{r}989 \\
1978 \\
1978 \\
989\end{array}$ & $\begin{array}{l}1080 \\
2159 \\
2139 \\
2040 \\
1921 \\
1921 \\
1921 \\
1921 \\
1921 \\
1921 \\
2159 \\
2159 \\
2159 \\
652\end{array}$ & $\begin{array}{r}594 \\
1180 \\
1188 \\
394\end{array}$ & $\begin{array}{l}217 \\
217 \\
217 \\
217 \\
217 \\
217 \\
217 \\
217 \\
217 \\
217 \\
217 \\
217 \\
217 \\
217 \\
217 \\
217 \\
217\end{array}$ & $\begin{array}{r}5908 \\
1706 \\
12101 \\
15595 \\
4754 \\
4354 \\
5246 \\
2130 \\
2130 \\
2138 \\
2138 \\
2138 \\
2150 \\
2576 \\
2376 \\
2576 \\
6740\end{array}$ & $\begin{array}{r}5908 \\
1751 \\
116 \pm 1 \\
12613 \\
4022 \\
3944 \\
2907 \\
1861 \\
18=5 \\
1789 \\
1754 \\
1720 \\
1686 \\
1957 \\
1801 \\
1765 \\
4910\end{array}$ \\
\hline TOTAL & 21123 & 5556 & 5934 & 31964 & 3564 & 3689 & $710=0$ & 65690 \\
\hline
\end{tabular}

- Decommissioning cost

Initial Payment = J5e c/KgU (Includes $55 / \mathrm{Kg}$ impact aid)

Final Payment = EII $5 / \mathrm{Kgl}$ (Includes $510 / \mathrm{KgL}$ impact aid)

TABLE A10-19

COST SENSITIVITY CASE - 5 YEAR EXTENSION OF FIS PROGRAM

ESTIMATED SPENDING SCHEDULE FOR STORAGE OF 236 DRYWELLS (100 MTU) AT GDVERNIENT SITE WITHOUT EXISTING FACILITIES

$(\$ 000,1987)$

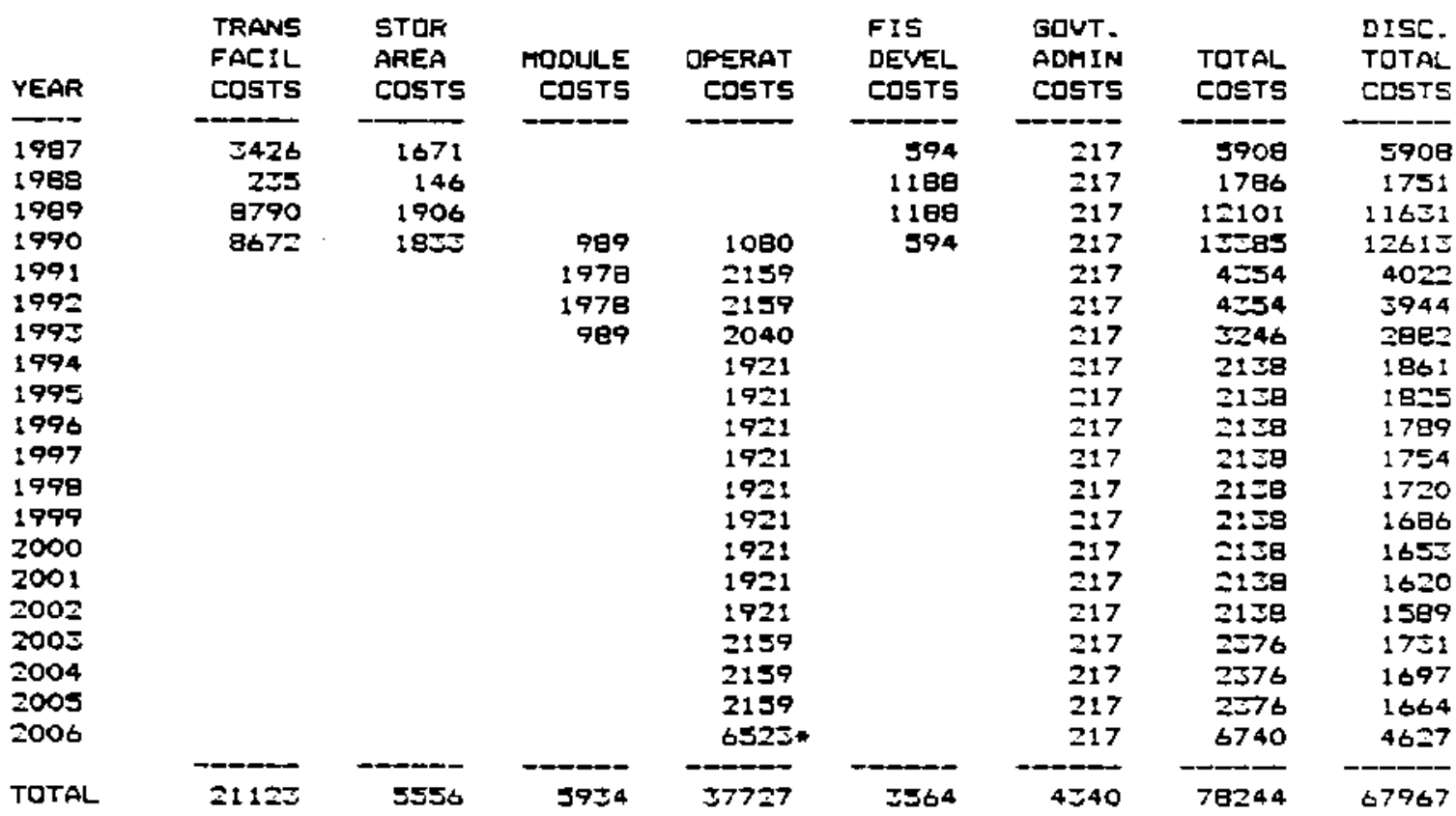

* Decommissioning cost

\footnotetext{
Inisial Payment $x$ F5e s/kgل (Includes IS/Kigl impact ald)

Final Fayment $=307$ r/kgl (Includes rio/rgu impact did)
} 
TABLE A1O-20

COST SENSITIVITY CASE - 2 YEAR EXIENSION OF FIS PROGRAM

ESTIMATED SPENDING STHEDULE FOR STORAGE OF 447B DRYWELLS (1900 MTU) AT GOVERNMENT SITE WITHOUT EXISTING FACILITIES $( \pm 000,1987)$

\begin{tabular}{|c|c|c|c|c|c|c|c|c|}
\hline YEAR & $\begin{array}{l}\text { TRANS } \\
\text { FACIL } \\
\text { CDSTS }\end{array}$ & $\begin{array}{l}\text { STQR } \\
\text { AREA } \\
\text { COSTS }\end{array}$ & $\begin{array}{r}\text { MOCULE } \\
\text { COSTS }\end{array}$ & $\begin{array}{r}\text { OPERAT } \\
\text { COSTS }\end{array}$ & $\begin{array}{l}\text { FIS } \\
\text { DEUEL } \\
\text { COSTS }\end{array}$ & $\begin{array}{l}\text { GOUT. } \\
\text { ADMIN } \\
\text { COSTS }\end{array}$ & $\begin{array}{l}\text { TOTAL } \\
\text { COSTS }\end{array}$ & $\begin{array}{l}\text { DISC. } \\
\text { TDTAL } \\
\text { CCSTS }\end{array}$ \\
\hline $\begin{array}{l}1997 \\
1989 \\
1989 \\
1990 \\
1991 \\
1997 \\
1995 \\
1994 \\
1995 \\
1996 \\
1997 \\
1999 \\
1999 \\
2000 \\
2001 \\
2002 \\
2003\end{array}$ & $\begin{array}{r}3426 \\
275 \\
6790 \\
8 \in 72\end{array}$ & $\begin{array}{r}2086 \\
146 \\
\Sigma 294 \\
\Sigma 221\end{array}$ & $\begin{array}{l}16770 \\
37541 \\
37541 \\
16770\end{array}$ & $\begin{array}{c}5719 \\
7438 \\
7438 \\
5307 \\
\$ 176 \\
5176 \\
5176 \\
5176 \\
3176 \\
5176 \\
7438 \\
7439 \\
7438 \\
29499 *\end{array}$ & $\begin{array}{r}584 \\
1180 \\
1188 \\
594\end{array}$ & $\begin{array}{l}849 \\
849 \\
849 \\
849 \\
949 \\
849 \\
649 \\
849 \\
849 \\
849 \\
849 \\
849 \\
849 \\
849 \\
849 \\
649 \\
849\end{array}$ & $\begin{array}{r}6957 \\
2418 \\
14121 \\
55925 \\
45828 \\
45228 \\
24926 \\
4025 \\
4025 \\
4025 \\
4025 \\
4025 \\
4025 \\
8297 \\
8287 \\
8287 \\
29348\end{array}$ & $\begin{array}{r}6957 \\
2571 \\
1=575 \\
5=759 \\
42538 \\
41508 \\
=2134 \\
5504 \\
5455 \\
5568 \\
\vdots 302 \\
3257 \\
3174 \\
6406 \\
6281 \\
6157 \\
21578\end{array}$ \\
\hline TOTAL & 21123 & 8749 & $11: 262=$ & 93771 & 5564 & בتב44 & 254262 & 2ว2ย8: \\
\hline
\end{tabular}

- Decomaissioning cost

$$
\begin{aligned}
& \text { Initial Payment }=77 \$ / \mathrm{KgU} \text { (Includes } \$ 4 / \mathrm{KgU} \text { impact aid) } \\
& \text { Final Paymant }=585 / \mathrm{KgU} \text { (Includes } \$ 9 / \mathrm{KgU} \text { impact did) }
\end{aligned}
$$

TABLE A10-21

COST SEMSITIVITY CASE — 5 YEAR EXTENSION OF FIS PROGRAH

ESTIMATED SPENDING SOHEDULE FOR STORAGE DF 4479 DRYWELLS ( 1900 MTU) AT GDUERMMENT 52 TE WITHDUT EXISTING FACILITIES

\begin{tabular}{|c|c|c|c|c|c|c|c|c|}
\hline YEAR & $\begin{array}{l}\text { TFANS } \\
\text { FACIL } \\
\text { COSTS }\end{array}$ & $\begin{array}{l}\text { STOR } \\
\text { AFEA } \\
\text { COSTS }\end{array}$ & $\begin{array}{l}\text { MODULE } \\
\text { COSTS }\end{array}$ & $\begin{array}{r}\text { OPERAT } \\
\text { COSTS }\end{array}$ & $\begin{array}{l}\text { FIS } \\
\text { DEVEL } \\
\text { CUSTS }\end{array}$ & $\begin{array}{l}\text { GDVT. } \\
\text { ADMIN } \\
\text { COSTS }\end{array}$ & $\begin{array}{l}\text { TOTAL } \\
\text { COSTS }\end{array}$ & $\begin{array}{l}\text { DISC. } \\
\text { TOTAL } \\
\text { CDSTS }\end{array}$ \\
\hline $\begin{array}{l}1987 \\
1998 \\
1989 \\
1990 \\
1991 \\
1992 \\
1993 \\
1994 \\
1995 \\
1996 \\
1997 \\
1999 \\
1999 \\
2000 \\
2001 \\
2002 \\
2003 \\
2004 \\
2005 \\
2004\end{array}$ & $\begin{array}{r}5426 \\
255 \\
9790 \\
8672\end{array}$ & $\begin{array}{r}2089 \\
146 \\
3294 \\
5221\end{array}$ & $\begin{array}{l}19770 \\
37541 \\
37541 \\
13770\end{array}$ & $\begin{array}{c}5719 \\
7439 \\
7438 \\
5307 \\
3176 \\
5176 \\
5176 \\
5176 \\
3176 \\
3176 \\
3176 \\
3176 \\
3176 \\
7438 \\
7438 \\
7439 \\
28499 *\end{array}$ & $\begin{array}{r}594 \\
1188 \\
1188 \\
594\end{array}$ & $\begin{array}{l}849 \\
849 \\
849 \\
949 \\
849 \\
949 \\
949 \\
949 \\
949 \\
949 \\
949 \\
949 \\
949 \\
949 \\
949 \\
949 \\
849 \\
949 \\
849 \\
949\end{array}$ & $\begin{array}{r}6757 \\
2411 \\
14121 \\
35825 \\
45829 \\
45029 \\
24926 \\
4025 \\
4025 \\
4025 \\
4025 \\
4025 \\
4025 \\
4025 \\
4025 \\
4025 \\
8297 \\
8297 \\
8297 \\
29340\end{array}$ & 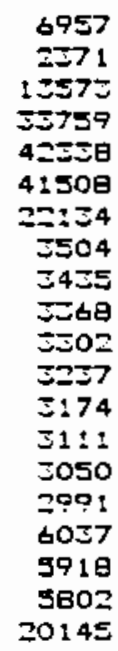 \\
\hline TOTAL & ב211 & 8749 & 1126: & $10=290$ & 5564 & 16780 & 26057 & $2=9714$ \\
\hline
\end{tabular}

$(\$ 000,1987)$

* Decommissioning cost 
TABLE A10-22

COST SENSITIVITY CASE - 2 YEAR EXTENSION OF FIS PROGRAM

ESTIMATED SPENDINE SCMEDULE FOR STORAGE OF 2JG DRYWELLS (1DO MTU) AT GOUERNMENT SITE WITH EXISTING FACILITIES $(9.000,1987)$

\begin{tabular}{|c|c|c|c|c|c|c|c|c|}
\hline YEAF & $\begin{array}{l}\text { TFANS } \\
\text { FACIL } \\
\text { COSTS }\end{array}$ & $\begin{array}{l}\text { STOR } \\
\text { AREA } \\
\text { COSTS }\end{array}$ & $\begin{array}{r}\text { MODULㄷ } \\
\text { COSTS }\end{array}$ & $\begin{array}{r}\text { APERAT } \\
\text { CESTS }\end{array}$ & $\begin{array}{l}\text { FIS } \\
\text { DEUEL } \\
\text { ECSTS }\end{array}$ & $\begin{array}{l}\text { GOUT, } \\
\text { ADMIN } \\
\text { COSTS }\end{array}$ & $\begin{array}{l}\text { TATAL } \\
\text { COSTS }\end{array}$ & $\begin{array}{l}\text { DISC. } \\
\text { TOTAL } \\
\text { COSTS }\end{array}$ \\
\hline :907 & $150 \theta$ & 1697 & & & 594 & 217 & 4016 & 4016 \\
\hline 1980 & 107 & 146 & & & 1190 & 217 & 1658 & 1625 \\
\hline 1909 & EB26 & 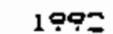 & & & 11日日 & $2: 7$ & 7223 & 6945 \\
\hline 1990 & 得 & $19: 9$ & 989 & 1050 & 594 & 217 & 9542 & 8049 \\
\hline 1991 & & & 1978 & 2009 & & $=\$ 7$ & 4994 & 5967 \\
\hline $199=$ & & & 1970 & 2099 & & 217 & $4 \geq 04$ & 5899 \\
\hline $19 \square$ & & & 909 & 1610 & & 217 & 2824 & 2500 \\
\hline 1994 & & & & 1136 & & 217 & $1=\Xi \Xi$ & $: 178$ \\
\hline 1995 & & & & 6 115 & & $=17$ & $1 \sum S$ & 1155 \\
\hline 1996 & & & & 1156 & & $2: 7$ & $1 \Xi 5 \Xi$ & $11: 2$ \\
\hline 1997 & & & & 1136 & & $=17$ & 1 & 1210 \\
\hline 1998 & & & & 1236 & & $2: 7$ & 1Z5J & 1089 \\
\hline 1999 & & & & $11 \Xi 0$ & & 217 & $175 \Sigma$ & 1067 \\
\hline 2000 & & & & 2099 & & 217 & $2 \Xi 16$ & 1790 \\
\hline 2001 & & & & 2099 & & 217 & TE16 & 1755 \\
\hline 2002 & & & & 2099 & & 217 & 2316 & 1721 \\
\hline 2003 & & & & $4180 *$ & & 217 & 4597 & 3203 \\
\hline TOTAL & 9214 & 5754 & 5934 & 24159 & 5564 & 广699 & 52314 & 46196 \\
\hline
\end{tabular}

- Decommissioning cost

Initial Payment $=244 * / \mathrm{Kg} U$ (Ineludes $55 / \mathrm{KgU}$ impact aid)

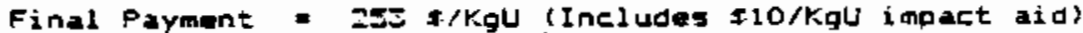

TABLE A10-23

COST SENSITIVITY CASE -- 5 YEAR EXTENSION OF FIS PROGRAH

ESTIMATED SPENDING SCHEDULE FCR STORAGE OF 236 DRYWELLS (100 MTU) AT GOVEFNMENT SITE WITH EXISTING FACILITIES $(x 000,2997)$

\begin{tabular}{|c|c|c|c|c|c|c|c|c|}
\hline YEAF & $\begin{array}{l}\text { TRANS } \\
\text { FACIL } \\
\text { CaSTS }\end{array}$ & $\begin{array}{l}\text { STUR } \\
\text { AREA } \\
\text { COSTS }\end{array}$ & $\begin{array}{r}\text { MODULE } \\
\text { COSTS }\end{array}$ & $\begin{array}{r}\text { QFERAT } \\
\text { COSTS }\end{array}$ & $\begin{array}{l}\text { FIS } \\
\text { DEVEL } \\
\text { EDSTS }\end{array}$ & $\begin{array}{l}\text { GDVT. } \\
\text { AOHIN } \\
\text { EDSTS }\end{array}$ & $\begin{array}{l}\text { TOTAL } \\
\text { COSTS }\end{array}$ & $\begin{array}{l}\text { OISC. } \\
\text { IロTAL } \\
\text { CDSTS }\end{array}$ \\
\hline 1797 & 1508 & 1697 & & & 394 & 217 & 4016 & 4016 \\
\hline 1989 & 107 & 146 & & & $11 \mathrm{Eg}$ & 217 & 1658 & 1675 \\
\hline 1989 & jB2t & 1992 & & & 1190 & 217 & 729 & 6943 \\
\hline 1990 & $\Xi 77$ & 1919 & 989 & 1050 & 594 & 217 & 9542 & 8049 \\
\hline 1991 & & & 1978 & 2094 & & 217 & 4294 & $\$ 967$ \\
\hline 1992 & & & 1978 & 2099 & & $=27$ & 4294 & z889 \\
\hline 1095 & & & 989 & $16: 8$ & & 217 & $28 \geq 4$ & 2500 \\
\hline 1994 & & & & 1136 & & 217 & 135 & 2178 \\
\hline 1995 & & & & 1136 & & 217 & ISSE & $1: 55$ \\
\hline 1996 & & & & 1136 & & 217 & 1353 & $11=2$ \\
\hline 1997 & & & & 1136 & & 217 & $1 \pm 3$ & 2110 \\
\hline 1990 & & & & 11ذ & & 217 & 1353 & 1098 \\
\hline 1999 & & & & $11{ }^{6}$ & & 217 & 1353 & 1067 \\
\hline 2000 & & & & 1136 & & 217 & $1=5=$ & 1046 \\
\hline 2001 & & & & $11 \approx 6$ & & 217 & $125 \pm$ & 102 \\
\hline 2002 & & & & 1136 & & 217 & $1=53$ & 1005 \\
\hline 2003 & & & & 2099 & & 217 & $2=16$ & 1687 \\
\hline 2004 & & & & 2099 & & $=17$ & $=316$ & 165 \\
\hline 2005 & & & & 2099 & & 217 & $2=16$ & $16=2$ \\
\hline 2006 & & & & $41 \mathrm{BO}$ & & 217 & 4: & SOI \\
\hline & gnt & $=7 * A$ & יח= & 7 & -5 & 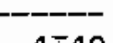 & - & \\
\hline
\end{tabular}

* Decammissioning cast

\footnotetext{
Initial Payment $=244$ r/rgU (Includes EE/Kigl impact aid)

Final Favment = Fez s/rgl (Includes $110 / \mathrm{kg}$ impact ald
} 
TABLE A10-24

COST SENSITIVITY CASE - 2 YEAR EXTENSION OF FIS PROGRAM

ESTIMATED SPENDING SCHEDULE FUR STARAGE OF 4478 DRYWELLS (1900 MTU)

AT GQVERNMENT SITE WITH EXISTING FACILITIES

(ะ000, :987)

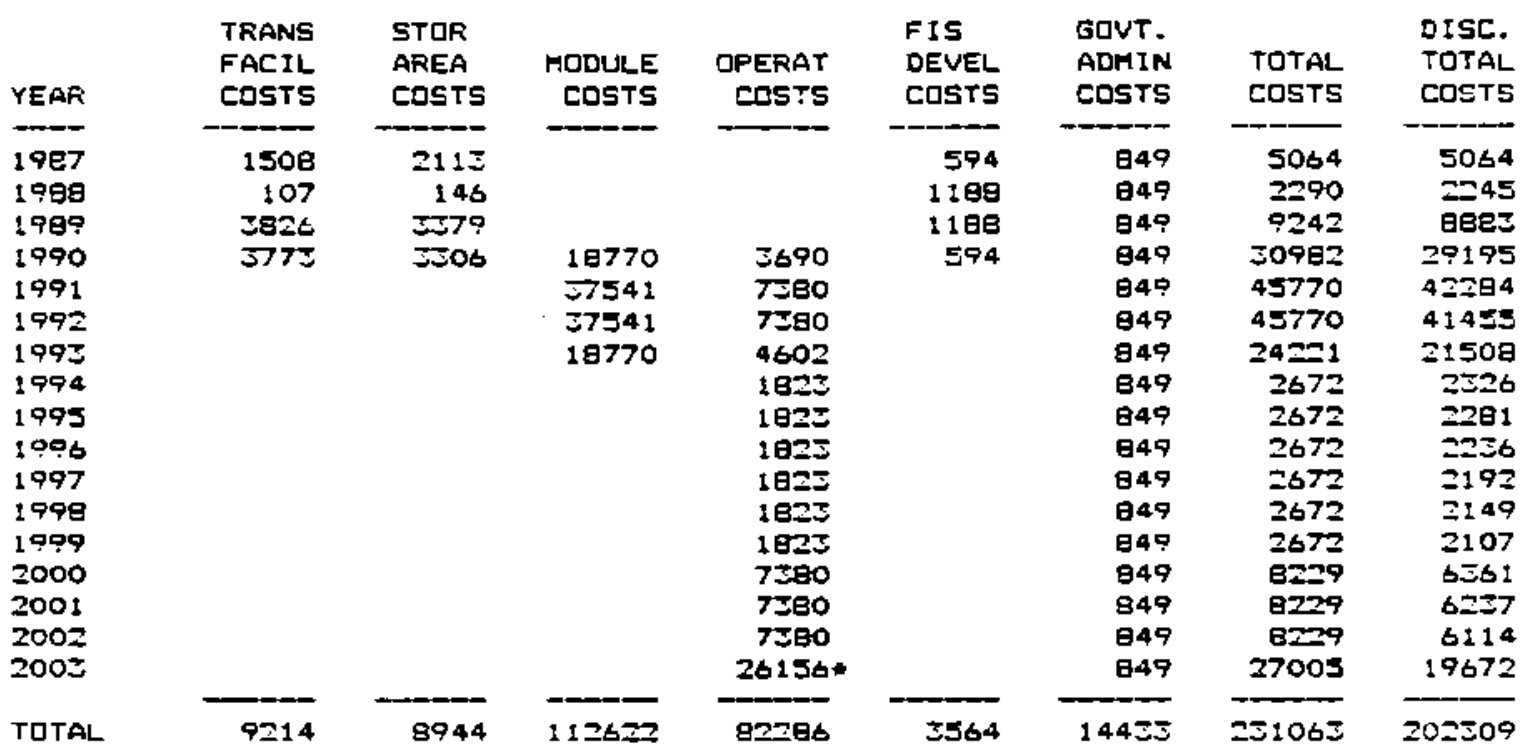

* - Decammissioning cast

Initial fayment $=71$ s/Kgl (Includes $54 / \mathrm{kgl}$ impact aid)

Final Payment = 51 s/KgU (Includes Eg/Kgl impact aid)

TABLE A10-25

COST SENSITIVITY CASE - 5 YEAR EXTENSION OF FIS PROGRAM

ESTIMATED SPENDING SCHEDLLE FOR STIRAGE OF 4479 DRYWELLS (1900 MTU)

AT GOVERNMENT SITE WITH EXISTING FACILITIES ( 1000,1987$)$

\begin{tabular}{|c|c|c|c|c|c|c|c|c|}
\hline YEAF & $\begin{array}{l}\text { TRANS } \\
\text { FACIL } \\
\text { COSTS }\end{array}$ & $\begin{array}{l}\text { STDR } \\
\text { AREA } \\
\text { EGSTS }\end{array}$ & $\begin{array}{l}\text { MODLLE } \\
\text { COSTS }\end{array}$ & $\begin{array}{r}\text { QFEFAT } \\
\text { COSTS }\end{array}$ & $\begin{array}{l}\text { FIS } \\
\text { DEVVEI } \\
\text { COSTS }\end{array}$ & $\begin{array}{l}\text { GDVT. } \\
\text { ADMIN } \\
\text { CDSTS }\end{array}$ & $\begin{array}{l}\text { TUTAL } \\
\text { COSTS }\end{array}$ & $\begin{array}{l}\text { DISC. } \\
\text { TUTAL } \\
\text { CISTS }\end{array}$ \\
\hline 1997 & 1508 & 2112 & & & 594 & 849 & 5064 & $\begin{array}{l}3064 \\
7-45\end{array}$ \\
\hline $19 \mathrm{E \theta}$ & 107 & 146 & & & 1188 & 849 & 2790 & $==45$ \\
\hline 1789 & 3826 & $=\$ 79$ & & & $118 \theta$ & 949 & 9242 & घ8日3 \\
\hline 1990 & 3773 & 3006 & 18770 & $\$ 670$ & 594 & 849 & 30982 & 29195 \\
\hline $199:$ & & & 57541 & $7=90$ & & 949 & 45770 & $4=284$ \\
\hline 1997 & & & $57 \leqslant 41$ & 7380 & & 949 & 45770 & 41455 \\
\hline 1993 & & & 18770 & 4602 & & 849 & $24 \geq 21$ & 21500 \\
\hline 1994 & & & & 1820 & & 949 & 2672 & בפבה \\
\hline 1993 & & & & 1825 & & $84 \%$ & 2672 & 228: \\
\hline 1996 & & & & 1日こะ & & 84? & 2672 & $2=36$ \\
\hline 1997 & & & & 1823 & & 847 & 2672 & $2: 97$ \\
\hline 1990 & & & & 1023 & & 849 & 2672 & $=149$ \\
\hline 1999 & & & & 1823 & & 949 & 2672 & $=107$ \\
\hline 2000 & & & & $1 \mathrm{EZZ}$ & & $84{ }^{\circ}$ & 2672 & 2006 \\
\hline 2001 & & & & $1 \mathrm{EZZ}$ & & 849 & 2672 & 2025 \\
\hline 2002 & & & & :日こZ & & 947 & 2672 & 1908 \\
\hline 2003 & & & & 7380 & & 84! & 日229 & 5794 \\
\hline 2004 & & & & 7ت日0 & & 1949 & e229 & se77 \\
\hline 2005 & & & & 7 7\%0 & & 849 & e229 & 5762 \\
\hline 2006 & & & & $26156 *$ & & 847 & 27005 & $185=7$ \\
\hline TOTAL & 9214 & 9944 & $1126=2$ & 977ธ5 & 2564 & 16980 & 239079 & 206171 \\
\hline
\end{tabular}

* - Decommissianing cost 
The impact on FIS costs of spreading the time for receipt of spent fuel at the FIS facility from the 3-year period set forth in Section 3.4 to a total of 4 years and 5 years, respectively, is shown in Table A10-26.

TABLE A10-26

IMPACT OF SPREADING THE TIME FOR RECEIPTS OF SPENT FUEL

AT FIS FACILITIES ON FIS SYSTEM COSTS

Number of Years

Spent Fuel Received

New Transfer Facility

Cases

3 yrs. (Base Case)

4 yrs.

5 yrs.

Change per yr. of receipt time

Existing Transfer Facility Cases

3 yrs. (Base Case)
4 yrs.
5 yrs.
Change per yr. of
receipt time

$\begin{array}{cc}100 \text { MTU } & \\ \text { Dotal } & \text { Total } \\ \text { Uniscounted } & \text { Unit }\end{array}$

Cost $(\$ 000)$ Cost $(\$ / \mathrm{kgU})$

$\$ 60,709$

60,658

60,598

$-56$

$\$ 44,383$

44,964

45,540

$+579$
$\$ 646$

648

650

$+2$

$\$ 478$

487

495

$+8.5$
1900 MTU

$\begin{array}{cc}1900 \text { MTU } & \\ \text { Total } & \text { Tota? } \\ \text { Discounted } & \text { Unit }\end{array}$

Cost $(\$ 000) \quad$ Cost $(\$ / \mathrm{kg}())$

$\$ 218,096$

$\$ 131$

216,046

130

214,034

130

$-2,031$

$-0.5$
$\$ 121$

120

121

$\$ 199,603$
198,687
197,790
-907

The estimated spending schedules, discounted annual costs, and the calculation of the Initial and Final payments for FIS of spent fuel for each of the cases considered in Table Al0-26 are set forth in Tables Al0-27 through Al0-34. 
TABLE ALO-27

COST SENSITIVITY CASE -- 4 YEAR RECEIPT OF SPENT FUEL

ESTIMATED SFENDINE SCHEDULE FOR STOFAGE OF 23 G DRYWELLS (100 MTU) AT GOVERNMENT SITE WITHOUT EXISTIMG FACILITIES

(5:000,1787)

\begin{tabular}{|c|c|c|c|c|c|c|c|c|}
\hline YEAR & $\begin{array}{l}\text { TRANS } \\
\text { FACIL } \\
\text { COSTS }\end{array}$ & $\begin{array}{l}\text { STOR } \\
\text { AFEA } \\
\text { COSTS }\end{array}$ & $\begin{array}{l}\text { MaDULE } \\
\text { COSTS }\end{array}$ & $\begin{array}{r}\text { QPEFAT } \\
\text { CDSTS }\end{array}$ & $\begin{array}{l}\text { FIS } \\
\text { DEUEL } \\
\text { CDSTS }\end{array}$ & $\begin{array}{l}\text { GOUT. } \\
\text { ADMIN } \\
\text { COSTS }\end{array}$ & $\begin{array}{l}\text { TOTAL } \\
\text { COSTS }\end{array}$ & $\begin{array}{l}\text { DI SC. } \\
\text { TUTAL } \\
\text { COSTS }\end{array}$ \\
\hline $\begin{array}{l}1987 \\
1980\end{array}$ & $\begin{array}{r}5426 \\
235\end{array}$ & $\begin{array}{r}1671 \\
146\end{array}$ & & & $\begin{array}{r}594 \\
1198\end{array}$ & $\begin{array}{l}2: 7 \\
217\end{array}$ & $\begin{array}{l}5900 \\
1706\end{array}$ & $\begin{array}{l}5908 \\
1751\end{array}$ \\
\hline 1989 & 日790 & 1901 & & & 1189 & 217 & 12101 & $1: 631$ \\
\hline 1990 & 8672 & 193 & 747 & 1051 & 594 & $2: 7$ & 15109 & $12=53$ \\
\hline 1991 & & & 1484 & $=101$ & & $2: 7$ & 3802 & 5512 \\
\hline 1992 & & & 1484 & 2101 & & 217 & 5902 & 3444 \\
\hline 1995 & & & 14.84 & $=101$ & & 217 & 5002 & $=76$ \\
\hline 1094 & & & 742 & 2011 & & 217 & 2970 & 2506 \\
\hline 1995 & & & & 1931 & & 217 & 2: & 1825 \\
\hline 1996 & & & & 1921 & & 217 & $21 \mathrm{~s}$ & 1789 \\
\hline 1997 & & & & 1921 & & $2: 7$ & 2: 28 & 1754 \\
\hline 1990 & & & & 2159 & & 217 & $2=76$ & $19: 1$ \\
\hline 1999 & & & & 2159 & & 217 & 2576 & $1 E 7 \coprod$ \\
\hline 2000 & & & & 2159 & & 217 & מ מדו & $18 \geq 7$ \\
\hline 2001 & & & & $652=$ & & 217 & $\$ 740$ & 5100 \\
\hline TUTAL & $=1123$ & מכ5כ & מכיז & 28120 & IS64 & ¿255 & 47562 & $60 € 58$ \\
\hline
\end{tabular}

* - Decommissioning cost.

Initial Payment $x \quad 557$ 5/KgU (Includes IS/KgU impact aid)

Final Payment: $=291$ s/kgU (Includes $510 / \mathrm{KgU}$ impact aid)

TABLE AIO-28

COST SENSITIVITY CASE - 5 YEAR RECEIPT OF SPENT FUEL

ESTIMATED SPENDIAG SCHEDULE FOR STRRAGE OF 236 DRYWELLS ( $100 \mathrm{MTU}$ ) AT GOVERMTENT S:TE WITHOUT EXISTING FACILITIES

$(\$ 000,1987)$

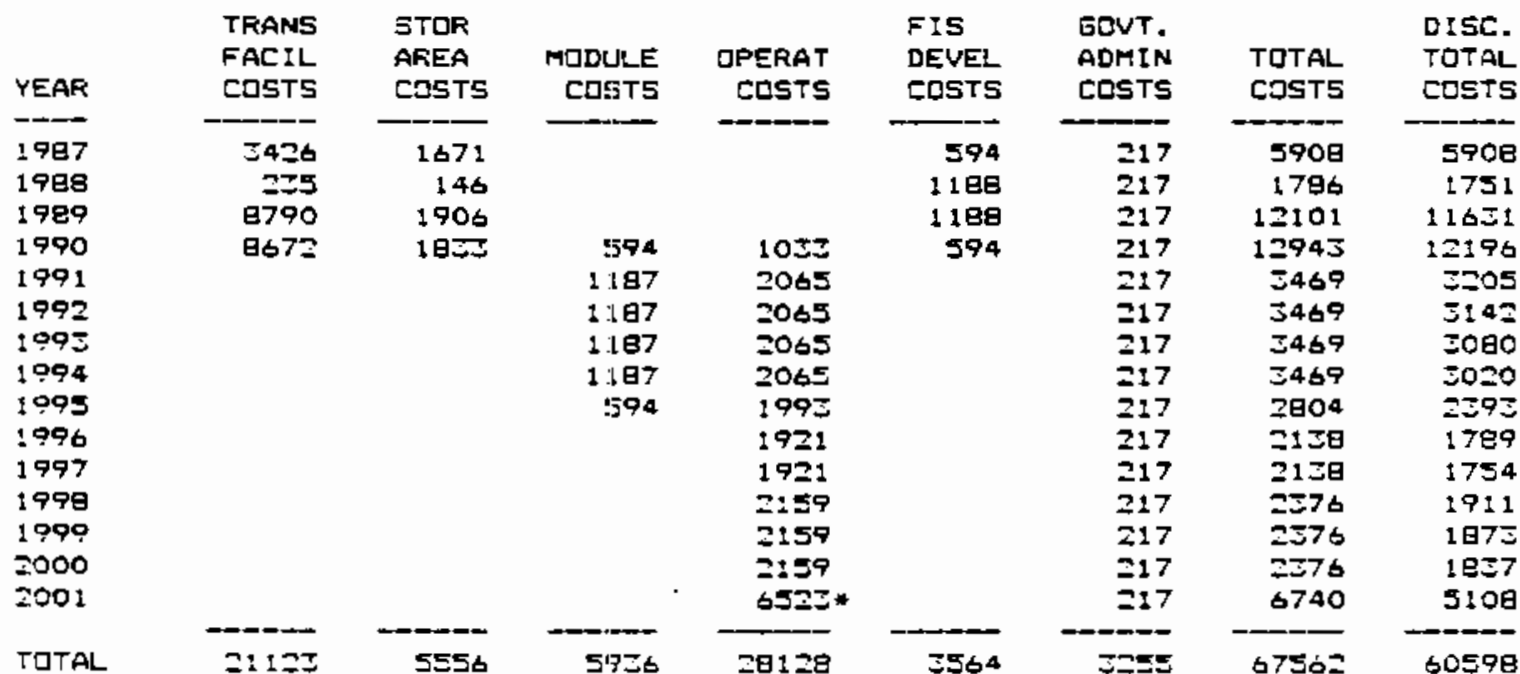

* - Decammissioning cast

\footnotetext{
Initial faymient $=357+\mathrm{Kg}$ (Includes $\mathrm{I} / \mathrm{kgl}$ impact aid)

Final Fayment = ב9J $5 / k g U$ (Incluctes $5: 10 / \mathrm{kgl}$ impact aid)
} 
TABLE A10-29

COST SENSITIVITY CASE $~-4$ YEAR RECEIPT OF SPENT FUEL

ESTIMATED SFEMDING SCHEDLLE FCF STORAGE DF 4479 DRYWELLS ( 1900 MTU) AT GOVERNMENT SITE WITHDUT EXISTING FACILITIES

(1000,1987)

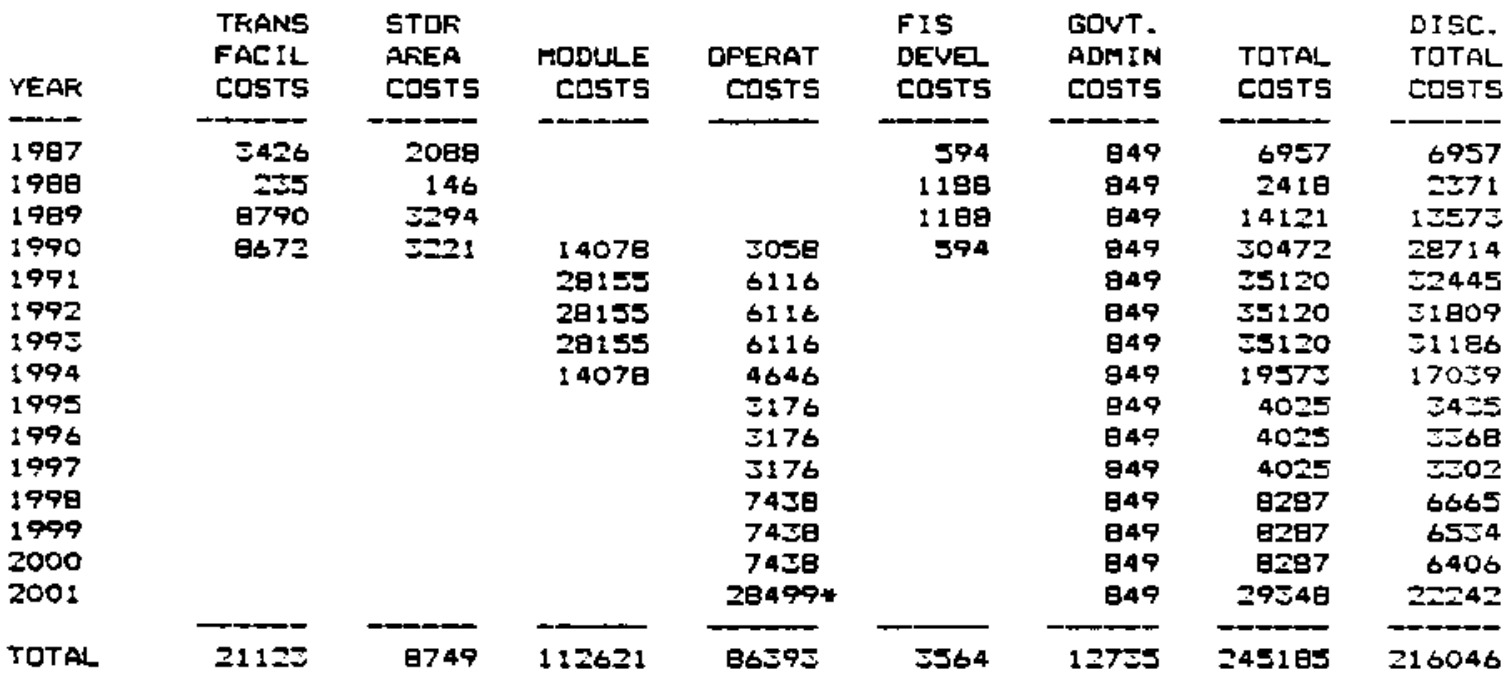

* - Decammissianing cont

Initial Payment $=76 \mathrm{~s} / \mathrm{KgU}$ (Includes $54 / \mathrm{Kg}$ impact aid)

Final Payment $=34 \mathrm{~s} / \mathrm{Kgl}$ (Includes $5 \mathrm{k} / \mathrm{KgU}$ impact aid)

TABLF A10-30

COST SEMSITIVITY CASE - 5 YEAR RECEIPT OF SPENT FUEL

ESTIMATED SPENDING SCHEDUL FQR STORAGE OF 447G DRYWELLS (1900 MTU) AT GOVERNAENT SITE WITHQUT EX ISTING FACILITIES (ะOL), 1987)

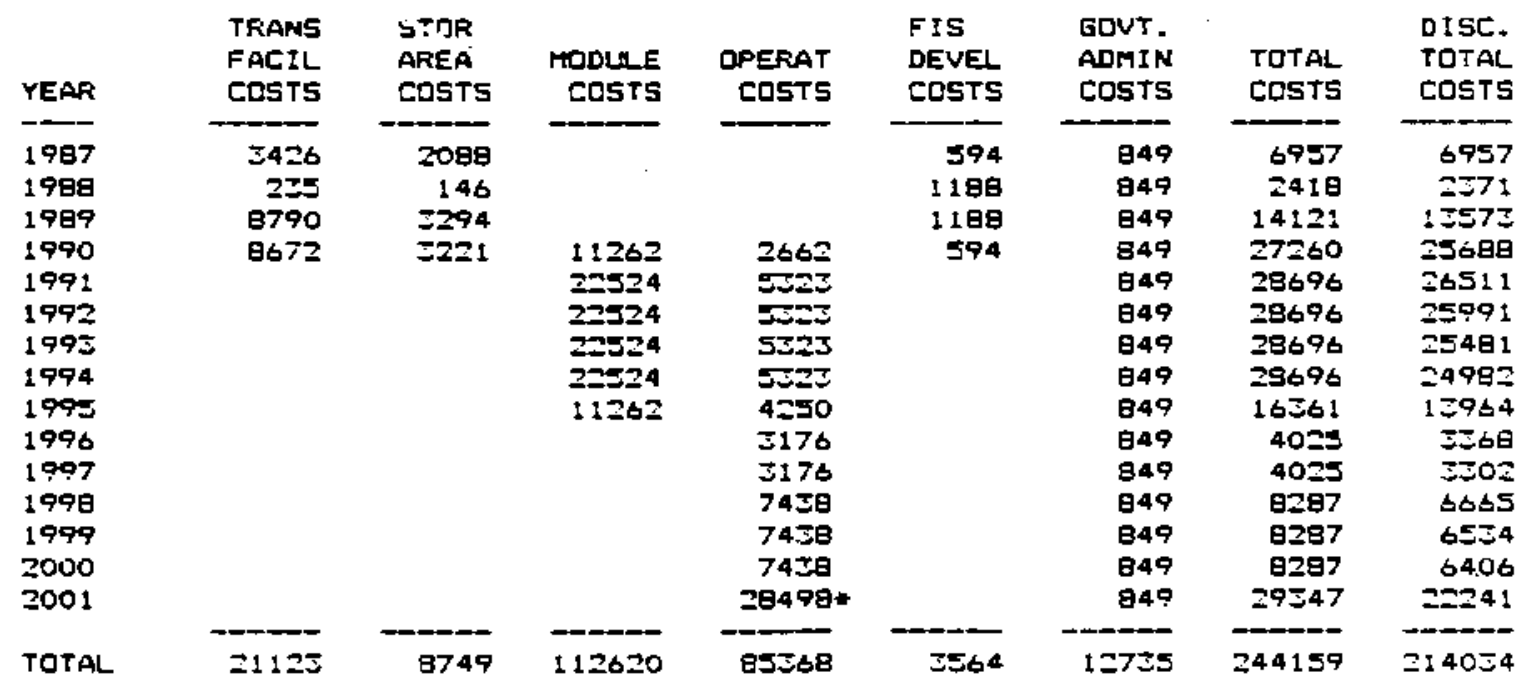

- - Decommissioning cogt

\footnotetext{
Initial Payment * $76 \mathrm{~s} / \mathrm{Kgl}$ (Includes $5.4 / \mathrm{Kgl}$ impact aid)

Final Payment $=54 \mathrm{x} / \mathrm{KgU}$ (Includes 5 s/kigu impact aid)
} 
TABLE A $10-31$

COST SENSITIVITY CASE $\cdots 4$ YEAR RECEIPT OF SPENT FUEL

ESTIMATED SFENDING 5CHEDULE FCR STORAGE OF 2JW ORYWELLS ( 100 MTU)

AT GQVERNMENT SITE WITH EXISTING FACILITIES (ะ000, 1987)

\begin{tabular}{|c|c|c|c|c|c|c|c|c|}
\hline YEAR & $\begin{array}{l}\text { TRANS } \\
\text { FACIL } \\
\text { COSTS }\end{array}$ & $\begin{array}{l}\text { STOF } \\
\text { AREA } \\
\text { COSTS }\end{array}$ & $\begin{array}{r}\text { MUDULE } \\
\text { COSTS }\end{array}$ & $\begin{array}{l}\text { QPERAT } \\
\text { COSTS }\end{array}$ & $\begin{array}{l}\text { FIS } \\
\text { DEVEL } \\
\text { CLSTS }\end{array}$ & $\begin{array}{l}\text { GOVT. } \\
\text { ADHIN } \\
\text { COSTS }\end{array}$ & $\begin{array}{l}\text { TOTAL } \\
\text { COSTS }\end{array}$ & $\begin{array}{l}\text { DISC. } \\
\text { TOTAL } \\
\text { COSTS }\end{array}$ \\
\hline $\begin{array}{l}1967 \\
1989 \\
1999 \\
1990 \\
1991 \\
1992 \\
1993 \\
1994 \\
1995 \\
1996 \\
1997 \\
1990 \\
1999 \\
2000 \\
2001\end{array}$ & $\begin{array}{r}1500 \\
107 \\
3926 \\
5773\end{array}$ & $\begin{array}{r}1697 \\
146 \\
1992 \\
1919\end{array}$ & $\begin{array}{r}742 \\
1484 \\
1484 \\
1484 \\
742\end{array}$ & $\begin{array}{l}1020 \\
2040 \\
2040 \\
2040 \\
1589 \\
1130 \\
1130 \\
1136 \\
2099 \\
2099 \\
2099 \\
4191\end{array}$ & $\begin{array}{r}594 \\
1189 \\
1168 \\
594\end{array}$ & $\begin{array}{l}217 \\
217 \\
217 \\
217 \\
217 \\
217 \\
217 \\
217 \\
217 \\
217 \\
217 \\
217 \\
217 \\
217 \\
217\end{array}$ & $\begin{array}{l}4016 \\
1658 \\
7223 \\
8265 \\
5741 \\
5741 \\
5741 \\
2547 \\
1355 \\
1353 \\
1353 \\
2316 \\
2316 \\
2316 \\
4598\end{array}$ & $\begin{array}{l}4016 \\
1625 \\
6943 \\
7780 \\
3456 \\
5080 \\
3529 \\
2217 \\
1155 \\
1132 \\
1110 \\
1865 \\
1826 \\
1790 \\
3030\end{array}$ \\
\hline TOTAL & $92: 4$ & 5754 & 3956 & $2=314$ & 5364 & $=255$ & $50 \Xi 77$ & 44964 \\
\hline
\end{tabular}

* - Decammissioning cost

Initial fayment = $244 \mathrm{x} / \mathrm{Kgl}$ (Ineludes $55 / \mathrm{KgU}$ impact aid)

Final Fayment $=24 \Xi \pm / K g u$ (Includes $* 10 / K g U$ impact aid)

TABLE A10-32

COST SENSITIYITY CASE — 5 YEAR RECEIPT OF SPENT FUEL

ESTIMATED SPENDING SCHEDLLE FUR STCRAGE OF 236 DRYWEZ LS (100 MTU) AT GOVERNMENT SITE WITH EXISTING FACILITIES $(\$ 000,1997)$

\begin{tabular}{|c|c|c|c|c|c|c|c|c|}
\hline YEAR & $\begin{array}{l}\text { TRANS } \\
\text { FACIL } \\
\text { CDSTS }\end{array}$ & $\begin{array}{l}\text { STDR } \\
\text { AFEA } \\
\text { COSTS }\end{array}$ & $\begin{array}{l}\text { MCDLLE } \\
\text { COSTS }\end{array}$ & $\begin{array}{r}\text { OFERAT } \\
\text { CESTS }\end{array}$ & $\begin{array}{l}\text { FIS } \\
\text { DEVE } \\
\text { ECSTS }\end{array}$ & $\begin{array}{l}\text { GOVT. } \\
\text { ADHIN } \\
\text { CDSTS }\end{array}$ & $\begin{array}{l}\text { TOTAL } \\
\text { COSTS }\end{array}$ & $\begin{array}{l}\text { DISC- } \\
\text { TOTAL } \\
\text { CDSTS }\end{array}$ \\
\hline $\begin{array}{l}1907 \\
1989 \\
1999 \\
1990 \\
1991 \\
1992 \\
1993 \\
1994 \\
1993 \\
1996 \\
1997 \\
1998 \\
1999 \\
2000 \\
3001\end{array}$ & $\begin{array}{r}1500 \\
107 \\
3826 \\
3775\end{array}$ & $\begin{array}{r}1697 \\
146 \\
1997 \\
1919\end{array}$ & $\begin{array}{r}594 \\
1187 \\
1197 \\
1187 \\
1197 \\
394\end{array}$ & $\begin{array}{l}1003 \\
2006 \\
2006 \\
2006 \\
2006 \\
1=71 \\
1136 \\
1136 \\
2099 \\
2099 \\
2099 \\
4191\end{array}$ & $\begin{array}{r}394 \\
1180 \\
1189 \\
594\end{array}$ & $\begin{array}{l}217 \\
217 \\
217 \\
217 \\
217 \\
217 \\
217 \\
217 \\
217 \\
217 \\
217 \\
217 \\
217 \\
217 \\
217\end{array}$ & $\begin{array}{l}4016 \\
1659 \\
73=3 \\
9100 \\
3410 \\
3410 \\
3410 \\
3410 \\
2382 \\
1353 \\
1535 \\
2310 \\
2316 \\
2316 \\
4399\end{array}$ & $\begin{array}{l}4016 \\
1625 \\
6943 \\
7650 \\
3150 \\
3099 \\
3029 \\
2969 \\
2030 \\
1130 \\
1110 \\
1662 \\
1826 \\
1790 \\
5320\end{array}$ \\
\hline TOTAL & 9214 & 5754 & 5936 & $2 \geq 48$ & 3364 & 3255 & 51071 & 45540 \\
\hline
\end{tabular}

* - Decommissioning east

\footnotetext{
Initial faymant $=24 \Xi \pm / K g U$ (Includes $t 5 / K g l$ impact aid)

Final Fayment $=2 \varepsilon z 5 / K g U$ (Includes $510 / k g U$ impact aid)
} 
TABLE A10-33

COST SENSITIVITY CASE - 4 YEAR RECEIPT OF SPENT FUEL

ESTIMATED SPENDING SCHEDULE FOR STMRAGE DF 447B DRYWELLS (1900 MTU)

AT GQVERNMENT SITE WITH EXISTING FACILITIES (\$000,1987)

\begin{tabular}{|c|c|c|c|c|c|c|c|c|}
\hline YEAR & $\begin{array}{l}\text { TRANS } \\
\text { FACIL } \\
\text { COSTS }\end{array}$ & $\begin{array}{l}\text { STOR } \\
\text { AFEA } \\
\text { CISTS }\end{array}$ & $\begin{array}{l}\text { MDDULE } \\
\text { COSTS }\end{array}$ & $\begin{array}{r}\text { QPERAT } \\
\text { COSTS }\end{array}$ & $\begin{array}{l}\text { FIS } \\
\text { DEVEL } \\
\text { COSTS }\end{array}$ & $\begin{array}{l}\text { GDVT. } \\
\text { ADMIN } \\
\text { COSTS }\end{array}$ & $\begin{array}{l}\text { TOTAL } \\
\text { COSTS }\end{array}$ & $\begin{array}{l}\text { DISE. } \\
\text { TOTAL } \\
\text { EOSTS }\end{array}$ \\
\hline $\begin{array}{l}1997 \\
1988\end{array}$ & $\begin{array}{r}: 508 \\
107\end{array}$ & $\begin{array}{r}211 \mathrm{~J} \\
146\end{array}$ & & & $\begin{array}{r}594 \\
1189\end{array}$ & $\begin{array}{l}949 \\
949\end{array}$ & $\begin{array}{l}5064 \\
=290\end{array}$ & $\begin{array}{l}5064 \\
=245\end{array}$ \\
\hline 1989 & 5826 & 279 & & & 1188 & 949 & 9242 & g8ez \\
\hline 1990 & $\$ 77 \Xi$ & 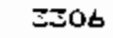 & 14078 & 5028 & 594 & 849 & ว5628 & 24150 \\
\hline 1991 & & & 29155 & s05t & & 849 & 53060 & $\Sigma=390$ \\
\hline 1992 & & & 28155 & $\operatorname{scs} \theta$ & & 849 & $\Sigma 5060$ & 31755 \\
\hline 1993 & & & 28155 & $\operatorname{sos} t$ & & 949 & 53060 & $31: 3 z$ \\
\hline 1994 & & & 14078 & 5940 & & 849 & $18 \theta \Delta 7$ & $1+425$ \\
\hline 1995 & & & & $1 \mathrm{E \geq 0}$ & & 849 & 2672 & $2=81$ \\
\hline 1906 & & & & $18=2$ & & 849 & 2672 & $=06$ \\
\hline 1997 & & & & 1日コร & & 849 & 2672 & 2192 \\
\hline 1998 & & & & $7=00$ & & 849 & $B=29$ & מ \\
\hline 1999 & & & & 7280 & & 849 & $8 \geq 79$ & 4489 \\
\hline 2000 & & & & $7=80$ & & 849 & $\theta=29$ & あこあ! \\
\hline 2001 & & & & 2615t* & & 849 & 27005 & 20466 \\
\hline TOTAL & $9=14$ & e944 & $1136=1$ & 78901 & 5564 & 12735 & $2=5979$ & 198687 \\
\hline
\end{tabular}

* - Decammissioning cost

Initial Payment $=705 / \mathrm{KgU}$ (Includes $44 / \mathrm{KgU}$ impact aid)

Final Payment $\Rightarrow 50 \mathrm{~s} / \mathrm{Kg}$ U (Ineludes $\mathbf{s} / \mathrm{KgU}$ impact aid)

TABLE AIO-34

COST SENSITIVITY CASE -- 5 YEAR RECEIPT OF SPENT FUEL

EST IMATED SPENDING SCHEDULE FOF STORAGE OF 4478 ORYWELLS (1900 MTU) AT GQVERNMENT SITE WITH EXISTING FACILITIES $(\$ 000,1987)$

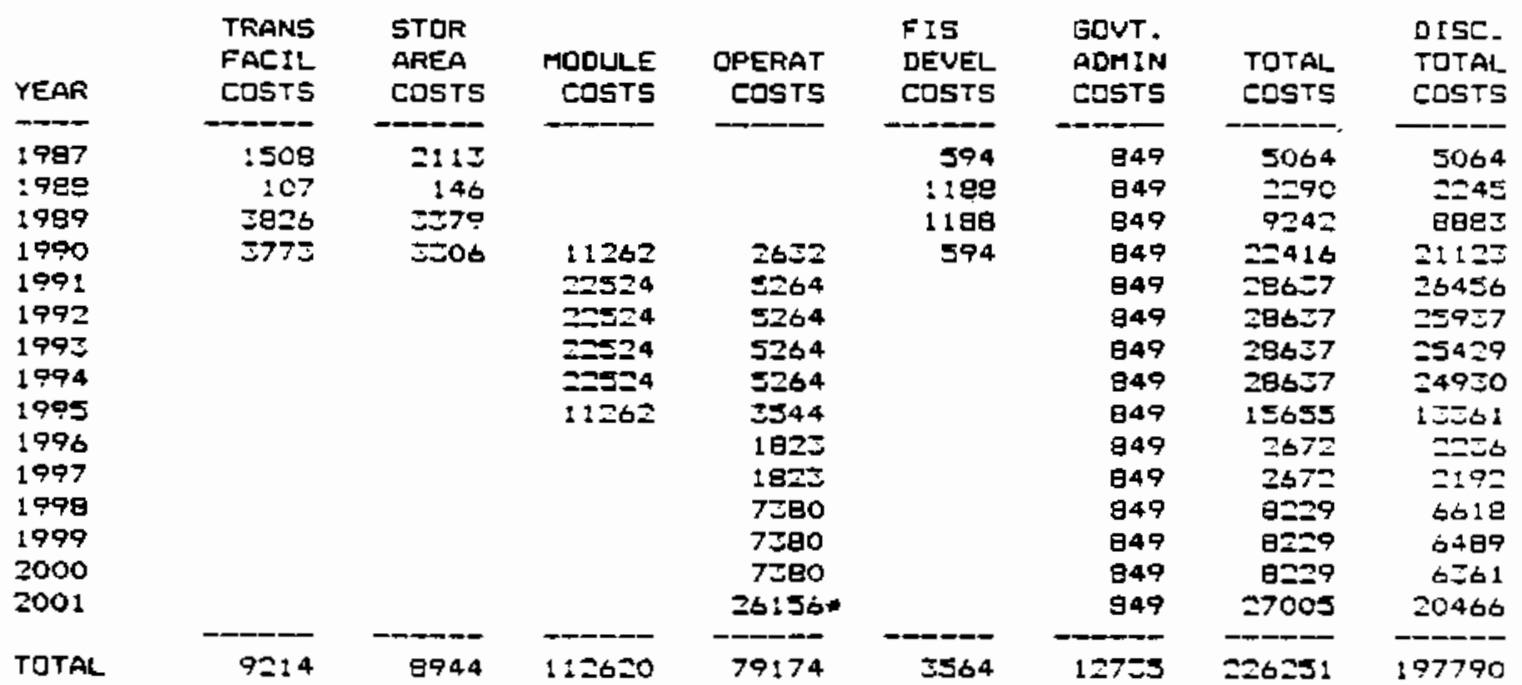

* - Decomaissioning cost

Initial Payment $=70 \mathrm{~s} / \mathrm{KgU}$ (Includes $14 / \mathrm{Kg} \mathrm{H}$ impact aid)

Final fayment $=5 ! 5 / k g U$ (Includes se/kgu impact ald) 
The impact on FIS costs of compressing the construction schedule for FIs facilities to a total of two years, compared with the base case of four years (implies no NRC licensing activities required), is shown in Table A10-35.

TABLE A10-35

IMPACT OF SHORTENING OF CONSTRUCTION TIME FOR FIS FACILITIES

ON FIS SYSTEM COSTS

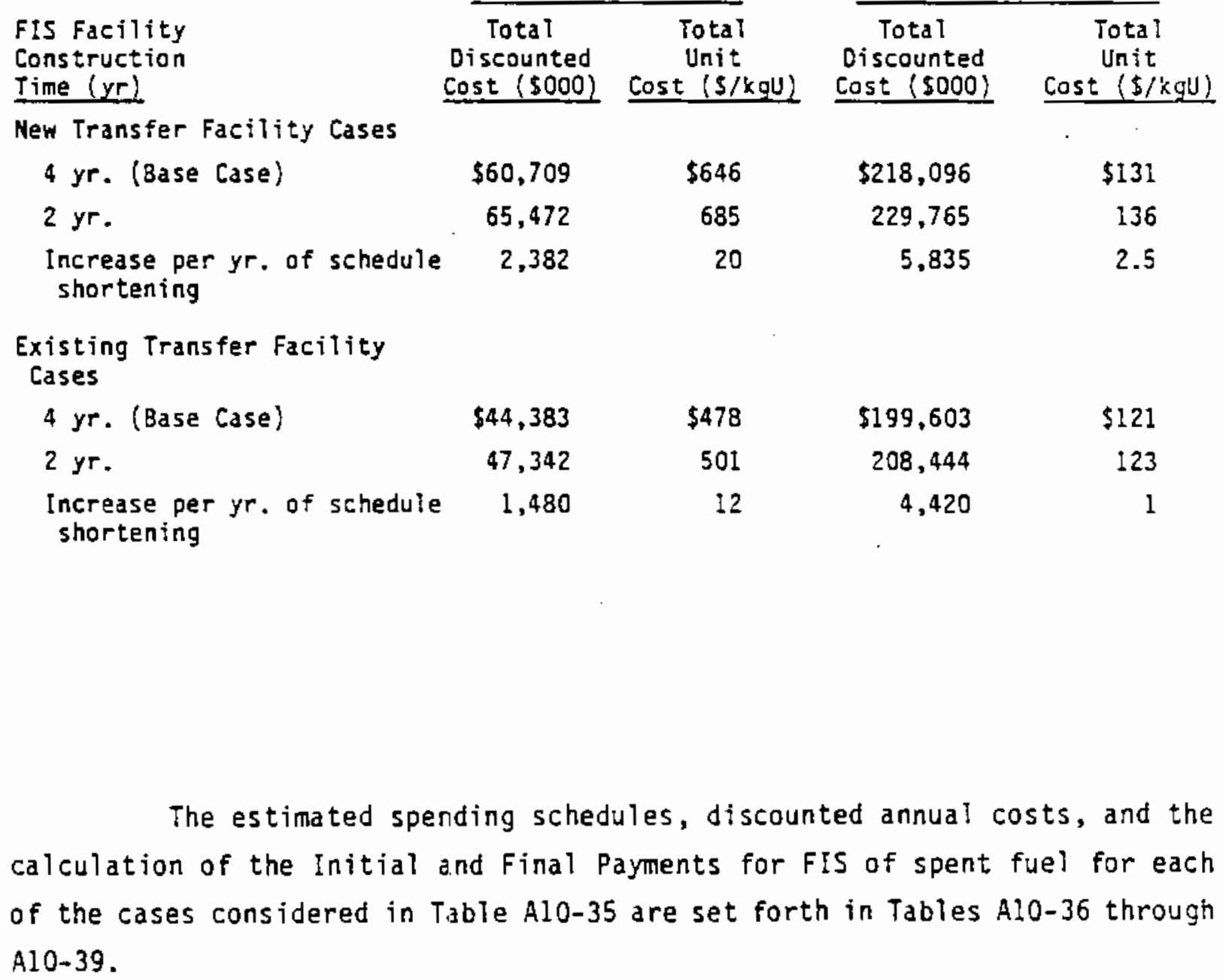

\begin{tabular}{|c|c|c|c|}
\hline \multicolumn{2}{|c|}{$100 \mathrm{MTU}$} & \multicolumn{2}{|c|}{$1900 \mathrm{MTU}$} \\
\hline $\begin{array}{c}\text { Total } \\
\text { Discounted } \\
\text { Cost }(\$ 000)\end{array}$ & $\begin{array}{c}\text { Total } \\
\text { Unit } \\
\text { Cost }(\mathrm{s} / \mathrm{kgU})\end{array}$ & $\begin{array}{c}\text { Total } \\
\text { Discounted } \\
\text { Cost }(\$ 000)\end{array}$ & $\begin{array}{c}\text { Total } \\
\text { Unit } \\
\text { Cost }(\$ / \mathrm{kgU})\end{array}$ \\
\hline
\end{tabular}

Iime (yr)

W Transfer Facility Cases

60,709

5,472

, 765

2.5

shortening

$\$ 199,603$

7,342

08,444

Increase per yr. of schedule

1,480

12

$$
4,420
$$


TABLE AIO- 36

COST SENSITIVITY CASE - 2-YEAR CONSTRUCTION SCHEDULE

ESTIMATED SFENDING SCHEDULE FOF STOFAGE DF 236 DFYWELLS $(100 \mathrm{MTU})$ AT GOVERNMENT SITE WITHOUT EXISTING FACILITIES (\$000, 1987)

\begin{tabular}{|c|c|c|c|c|c|c|c|c|}
\hline YEAR & $\begin{array}{l}\text { TRANS } \\
\text { FACIL } \\
\text { COSTS }\end{array}$ & $\begin{array}{l}\text { STDR } \\
\text { AREA } \\
\text { COSTS }\end{array}$ & $\begin{array}{l}\text { HCDULE } \\
\text { COSTS }\end{array}$ & $\begin{array}{l}\text { OPERAT } \\
\text { COSTS }\end{array}$ & $\begin{array}{l}\text { FIS } \\
\text { DEVEI } \\
\text { CDSTS }\end{array}$ & $\begin{array}{l}\text { GOVT. } \\
\text { ADMIN } \\
\text { COSTS }\end{array}$ & $\begin{array}{l}\text { TOTAL } \\
\text { COSTS }\end{array}$ & $\begin{array}{l}\text { DISC. } \\
\text { TOTAL } \\
\text { COSTS }\end{array}$ \\
\hline $\begin{array}{l}1997 \\
1988 \\
1989 \\
1990 \\
1991 \\
1992 \\
1995 \\
1994 \\
1995 \\
1996 \\
1997 \\
1990 \\
1999 \\
2000 \\
2001\end{array}$ & $\begin{array}{r}12451 \\
8672\end{array}$ & $\begin{array}{l}3724 \\
1833\end{array}$ & $\begin{array}{r}989 \\
1978 \\
1979 \\
989\end{array}$ & $\begin{array}{l}1080 \\
2159 \\
2159 \\
2040 \\
1021 \\
1921 \\
1921 \\
1921 \\
1921 \\
1921 \\
2159 \\
2159 \\
2159 \\
6523\end{array}$ & $\begin{array}{r}594 \\
1198 \\
1128 \\
594\end{array}$ & $\begin{array}{l}217 \\
217 \\
217 \\
217 \\
217 \\
217 \\
217 \\
217 \\
217 \\
217 \\
217 \\
217 \\
217 \\
217 \\
217\end{array}$ & $\begin{array}{r}16996 \\
13979 \\
5542 \\
4948 \\
3246 \\
2138 \\
2138 \\
2158 \\
2138 \\
2139 \\
2130 \\
2576 \\
3576 \\
2376 \\
6740\end{array}$ & $\begin{array}{l}16906 \\
15705 \\
5227 \\
4663 \\
2999 \\
1956 \\
1998 \\
1961 \\
1025 \\
1769 \\
1754 \\
1911 \\
1875 \\
1837 \\
5109\end{array}$ \\
\hline TOTAL & 21123 & 5557 & 5934 & 21964 & I564 & 3255 & $71 \Xi 97$ & $6547=$ \\
\hline
\end{tabular}

* - Dacommissioning cost

\author{
Initial Payment = $547 \% / \mathrm{KgU}$ (Includes s5/Kgl impact aid)

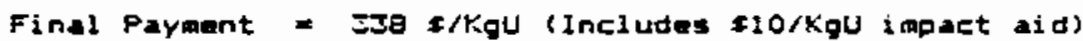

TABLE A10-37

COST SENSITIYITY CASE — 2-YEAR CONSTRUCTION SCHEOULE

ESTIMATED SPENDING SCHEDULE FOR STORAGE OF 4478 DRYWELLS ( 1900 MTU) AT GLVERNMENT SITE WITHOUT EXISTING FACILITIES $(x 000,1987)$

\begin{tabular}{|c|c|c|c|c|c|c|c|c|}
\hline YEAR & $\begin{array}{l}\text { TRANS } \\
\text { FACIL } \\
\text { COSTS }\end{array}$ & $\begin{array}{l}\text { STDR } \\
\text { AREA } \\
\text { CDSTS }\end{array}$ & $\begin{array}{l}\text { MODLAE } \\
\text { COSTS }\end{array}$ & $\begin{array}{r}\text { OPERAT } \\
\text { COSTS }\end{array}$ & $\begin{array}{l}\text { FIS } \\
\text { DEVEL } \\
\text { COSTS }\end{array}$ & $\begin{array}{l}\text { GOVT. } \\
\text { ADMIN } \\
\text { COSTS }\end{array}$ & $\begin{array}{l}\text { JOTAL } \\
\text { COSTS }\end{array}$ & $\begin{array}{l}\text { DISC. } \\
\text { TOTAL } \\
\text { COSTS }\end{array}$ \\
\hline $\begin{array}{l}1987 \\
1998 \\
1999 \\
1990 \\
1991 \\
1997 \\
1993 \\
1994 \\
1995 \\
1996 \\
1997 \\
1999 \\
1999 \\
2000 \\
2001\end{array}$ & $\begin{array}{r}12451 \\
9672\end{array}$ & $\begin{array}{l}5528 \\
3221\end{array}$ & $\begin{array}{l}18770 \\
37541 \\
57541 \\
18770\end{array}$ & $\begin{array}{l}5719 \\
7458 \\
7438 \\
5307 \\
3176 \\
3176 \\
3176 \\
3176 \\
3176 \\
5176 \\
7458 \\
7438 \\
7438 \\
29499 *\end{array}$ & $\begin{array}{r}594 \\
1128 \\
1188 \\
594\end{array}$ & $\begin{array}{l}949 \\
949 \\
849 \\
649 \\
849 \\
849 \\
949 \\
849 \\
649 \\
949 \\
949 \\
949 \\
849 \\
949 \\
949\end{array}$ & $\begin{array}{r}19422 \\
30419 \\
47016 \\
46422 \\
24926 \\
4025 \\
4025 \\
4025 \\
4023 \\
4025 \\
4023 \\
8297 \\
6267 \\
8267 \\
29346\end{array}$ & $\begin{array}{r}19472 \\
35705 \\
45190 \\
45744 \\
23028 \\
3646 \\
3574 \\
3504 \\
3435 \\
5368 \\
3502 \\
6665 \\
6534 \\
6406 \\
20242\end{array}$ \\
\hline TOTAL & $21: 23$ & 3749 & 112622 & $9 \pm 771$ & 3564 & 12735 & $\therefore=264$ & 209765 \\
\hline
\end{tabular}

* Decommissianing cost

\footnotetext{
Initial Payount $=78 \mathrm{~s} / \mathrm{Kgl}$ (Includes $54 / \mathrm{Kgl}$ impact did)

Final Payment $=5 \theta t / K g U$ (Includes $48 / \mathrm{kgU}$ impact aid)
} 
TABLE A10-38

COST SENSITIVITY CASE - 2-YEAR CONSTRUCTIOM SCHEDULE

ESTIMATED SPENOING SCHEDULE FDR STORAGE OF SSO DRYWELLS (:00 MTU)

AT GOVERNMENT SITE WITH EXISTING FACILITIES $( \pm 000,1987)$

\begin{tabular}{|c|c|c|c|c|c|c|c|c|}
\hline YEAR & $\begin{array}{l}\text { TRANS } \\
\text { FACIL } \\
\text { COSTS }\end{array}$ & $\begin{array}{l}\text { STOR } \\
\text { AFEA } \\
\text { COSTS }\end{array}$ & $\begin{array}{r}\text { RODULE } \\
\text { COSTS }\end{array}$ & $\begin{array}{l}\text { DPEFAT } \\
\text { COSTS }\end{array}$ & $\begin{array}{l}\text { FIS } \\
\text { DEVEL } \\
\text { COSTS }\end{array}$ & $\begin{array}{l}\text { GDVT. } \\
\text { ADMIN } \\
\text { CDSTS }\end{array}$ & $\begin{array}{l}\text { TOTAL } \\
\text { COSTS }\end{array}$ & $\begin{array}{l}\text { DISC. } \\
\text { TOTAL } \\
\text { COSTS }\end{array}$ \\
\hline $\begin{array}{l}1987 \\
1988 \\
1989 \\
1990 \\
1991 \\
1992 \\
1993 \\
1994 \\
1995 \\
1996 \\
1997 \\
1999 \\
1999 \\
2000 \\
2001\end{array}$ & $\begin{array}{l}5442 \\
3772\end{array}$ & $\begin{array}{l}\text { EES5 } \\
1919\end{array}$ & $\begin{array}{r}499 \\
1479 \\
1978 \\
429\end{array}$ & $\begin{array}{l}1050 \\
2099 \\
2099 \\
1619 \\
1136 \\
1130 \\
1130 \\
1136 \\
1136 \\
1130 \\
2099 \\
2099 \\
2099 \\
4181\end{array}$ & $\begin{array}{r}394 \\
1198 \\
11 \mathrm{Eg} \\
394\end{array}$ & $\begin{array}{l}217 \\
217 \\
217 \\
217 \\
217 \\
217 \\
217 \\
217 \\
=17 \\
217 \\
217 \\
217 \\
217 \\
217 \\
217\end{array}$ & 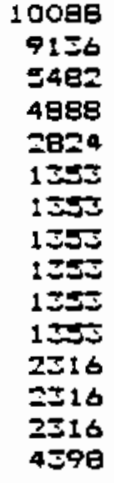 & $\begin{array}{r}10008 \\
9957 \\
3269 \\
4606 \\
2609 \\
1275 \\
1201 \\
1170 \\
1155 \\
1122 \\
1110 \\
11007 \\
1826 \\
1790 \\
5330\end{array}$ \\
\hline TOTAL & 9215 & 554 & 5934 & $=4160$ & 3564 & 3255 & 51802 & 47342 \\
\hline
\end{tabular}

* - Decoamissianing cast

Initial Fayment = 230 f/Kgl (Includes IS/Kgl impact aid)

Final Fayment: $=271+1 \mathrm{Kg} U$ (Includes $510 / \mathrm{KgU}$ impact aid)

TABLE A10-39

COST SENSITIVITY CASE -- 2-YEAR CONSTRUCTIOH SCHEDULE

ESTIMATED SPENDING SCHEDULE FOR STORAGE OF 4478 ORYWEH 1S (1900 MTU)

AT GOVERNUENT SITE WITH EXISTING FACILITIES

$(\$ 000,1987)$

\begin{tabular}{|c|c|c|c|c|c|c|c|c|}
\hline YEAR & $\begin{array}{l}\text { TRANS } \\
\text { FACIL } \\
\text { COSTS }\end{array}$ & $\begin{array}{l}\text { STOR. } \\
\text { AREA } \\
\text { COSTS }\end{array}$ & $\begin{array}{l}\text { MODULE } \\
\text { COSTS }\end{array}$ & $\begin{array}{r}\text { OPERAT } \\
\text { COSTS }\end{array}$ & $\begin{array}{l}\text { FYS } \\
\text { DEVEL } \\
\text { COSTS }\end{array}$ & $\begin{array}{l}\text { GOUT. } \\
\text { ADHIN } \\
\text { EOSTS }\end{array}$ & $\begin{array}{l}\text { TOTAL } \\
\text { CUSTS }\end{array}$ & $\begin{array}{l}\text { DISC. } \\
\text { TOTAL } \\
\text { COSTS }\end{array}$ \\
\hline $\begin{array}{l}1997 \\
1998 \\
1999 \\
1990 \\
1991 \\
1992 \\
1995 \\
1994 \\
1995 \\
1990 \\
1997 \\
1998 \\
1999 \\
2000 \\
2001\end{array}$ & $\begin{array}{l}5442 \\
=773\end{array}$ & $\begin{array}{l}5659 \\
506\end{array}$ & $\begin{array}{l}16770 \\
-7541 \\
=7541 \\
18770\end{array}$ & $\begin{array}{l}3690 \\
7380 \\
7500 \\
4602 \\
1822 \\
1022 \\
1922 \\
192= \\
1022 \\
1822 \\
7590 \\
7380 \\
7380 \\
26156 *\end{array}$ & $\begin{array}{r}594 \\
1169 \\
1189 \\
594\end{array}$ & $\begin{array}{l}849 \\
949 \\
849 \\
849 \\
949 \\
849 \\
849 \\
949 \\
949 \\
649 \\
849 \\
949 \\
849 \\
849 \\
949\end{array}$ & $\begin{array}{r}12524 \\
51576 \\
46959 \\
46564 \\
24221 \\
2672 \\
2672 \\
2677 \\
2672 \\
2672 \\
2672 \\
9229 \\
8229 \\
6229 \\
27005\end{array}$ & 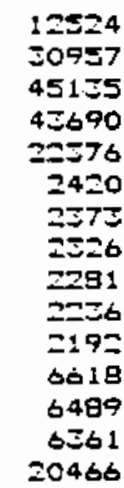 \\
\hline TOTAL & 9245 & 0945 & $1: 2 t 2=$ & $9=206$ & $\sum \equiv 64$ & 12735 & 299567 & 209444 \\
\hline
\end{tabular}

* Decommissioning cost

\footnotetext{
Initial Fayment $=71$ s/kgU (Ineludes r4/kgU impact aid)

Final Fayment $=52 \mathrm{~s} / \mathrm{Kgl}$ (Includes $\$ 8 / \mathrm{KgU}$ inpact aid)
} 


\section{I0.3 IMPACT OF MIX OF SPENT FUEL TYPES}

In developing the costs for FIS storage described in Section 9.0 of this Exhibit $A$, it was assumed that a mix of spent fuel would be received such that an average loading of a drywell would be 0.429 MTU (two-thirds of the fuel received would be PWR fuel containing 0.461 MTU/assembly, and one third of the fuel received would be BWR fuel containing $0.183 \mathrm{MTU} / \mathrm{assembly} \mathrm{-.} \mathrm{with}$ one PWR or two BWR assemblies being contained in a single drywel1). The impact of receiving 100\% PWR and 100\% BWR fuel on FIS costs is shown in Tabie A10-40.

TABLE ALO-40

IMPACT OF AMOUNT OF URANIUM CONTAINED IN A ORYWELL ON FIS SYSTEM COSTS

\begin{tabular}{cc}
\multicolumn{2}{c}{100 MTU } \\
\hline Total & Total \\
Oiscounted & Unit \\
Cost $(\$ 000)$ & Cost (\$/kgU) \\
\hline
\end{tabular}

\begin{tabular}{cc}
\hline \multicolumn{2}{c}{1900 MTU } \\
Total & Total \\
Oiscounted & Unit \\
Cost $(\$ 000)$ & Cost $(\$ / \mathrm{kgU})$ \\
\hline
\end{tabular}

New Transfer Facil ity Cases

\begin{tabular}{|c|c|c|c|c|}
\hline 67\% PWR Fuel (Base Case) & $\$ 60,709$ & $\$ 646$ & $\$ 218,096$ & $\$ 13 I$ \\
\hline $100 \%$ PHR Fue] & 60,180 & 641 & 208,222 & 125 \\
\hline 100\% BWR Fuel & 61,714 & 656 & 237,801 & 143 \\
\hline $\begin{array}{l}\text { Change per } \mathrm{kg} / \mathrm{U} \text { difference } \\
\text { in average content of } \\
\text { drywell }\end{array}$ & 16 & 0.16 & 311 & 0.19 \\
\hline \multicolumn{5}{|l|}{$\begin{array}{l}\text { xisting Transfer Facility } \\
\text { Cases }\end{array}$} \\
\hline 67: PWR Fuel (Base Case) & $\$ 44,383$ & $\$ 478$ & $\$ 199,603$ & $\$ 121$ \\
\hline $100 \%$ PWR Fuel & 43,855 & 473 & 189,730 & 114 \\
\hline I00: BWR Fuel & 45,400 & 489 & 219,314 & 131 \\
\hline $\begin{array}{l}\text { Change per } \mathrm{kg} / U \text { difference } \\
\text { in average content of } \\
\text { drywell }\end{array}$ & 16 & 0.17 & 311 & 0.18 \\
\hline
\end{tabular}

The estimated spending schedules, discounted annual costs, and the calculation of the Initial and Final Payments for FIS of spent fuel for each of the cases considered in Table A10-40 are set forth in Tables A10-41 through A10-48. 
TABLE A10-41

COST SENSITIVITY CASE -- 100\% PUR FUEL

ESTIMATED SFENDING SCHEDULE FOF STORAGE DF 217 ORYWELLS ( 100 MTU) AT GOVERNMENT SITE WITHOUT EXISTING FACILITIES

$(5000,1987)$

\begin{tabular}{|c|c|c|c|c|c|c|c|c|}
\hline YEAR & $\begin{array}{l}\text { TRANS } \\
\text { FACIL } \\
\text { COSTS }\end{array}$ & $\begin{array}{l}\text { STOR } \\
\text { AREA } \\
\text { COSTS }\end{array}$ & $\begin{array}{l}\text { MODULE } \\
\text { COSTS }\end{array}$ & $\begin{array}{r}\text { OPERAT } \\
\text { COSTS }\end{array}$ & $\begin{array}{l}\text { FIS } \\
\text { DEVEI } \\
\text { COSTS }\end{array}$ & $\begin{array}{l}\text { GDVT. } \\
\text { ADMIN } \\
\text { COSTS }\end{array}$ & $\begin{array}{l}\text { TUTAL } \\
\text { COSTS }\end{array}$ & $\begin{array}{l}\text { DISC. } \\
\text { TOTAL } \\
\text { COSTS }\end{array}$ \\
\hline $\begin{array}{l}1987 \\
1988\end{array}$ & $\begin{array}{r}3426 \\
235\end{array}$ & $\begin{array}{r}1475 \\
146\end{array}$ & & & $\begin{array}{r}594 \\
1189\end{array}$ & $\begin{array}{l}217 \\
217\end{array}$ & $\begin{array}{l}5909 \\
1796\end{array}$ & $\begin{array}{l}5909 \\
1751\end{array}$ \\
\hline 1989 & 979 & 1900 & & & 1138 & 217 & 12105 & $116=0$ \\
\hline 1990 & 8672 & 18E5 & 910 & 1078 & 594 & 217 & 13 SOS & 1255? \\
\hline 1991 & & & 1819 & 2156 & & 217 & 4192 & క275 \\
\hline 1992 & & & 1819 & 2156 & & 217 & 4192 & $\Xi 797$ \\
\hline 1975 & & & 910 & $20 \div 7$ & & 217 & $\Xi 164$ & $=910$ \\
\hline 1994 & & & & $191 \mathrm{\theta}$ & & 217 & Z155 & 1259 \\
\hline 1995 & & & & 1918 & & 217 & 2:155 & 1822 \\
\hline 1996 & & & & 1918 & & $=17$ & $21=5$ & 1786 \\
\hline 1997 & & & & 1918 & . & 217 & $21: 5$ & 1751 \\
\hline 1999 & & & & 2156 & & 217 & こシ7ミ & 1009 \\
\hline 1999 & & & & 2156 & & 217 & 2573 & 1971 \\
\hline 2000 & & & & 2156 & & 217 & 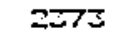 & $12=4$ \\
\hline 2001 & & & & $6428 *$ & & 217 & 6645 & 5036 \\
\hline TDTAL & 21123 & 5501 & 5458 & 27995 & IS54 & ¿255 & 66956 & 60190 \\
\hline
\end{tabular}

- Decomissianing cost

Initial fayment $=334 \mathrm{~s} / \mathrm{Kgl}$ (Ineludes $55 / \mathrm{KgU}$ impact aid)

Final Fayment $=207 \times / \mathrm{Kgl}$ (Ineludes $\$ 10 / \mathrm{Kgl}$ impact aid)

TABLF A10-42

COST SENSITIVITY CASE -- 100: BWR FUEL

ESTIMATED SPENDING SCHEDLLE FOR STORAGE OF 273 DRYWELLS - $(100 \mathrm{MTU})$ AT GOVERNMENT SITE WITHOUT EXISTING FACILITIES

$(\$ 000,1987)$

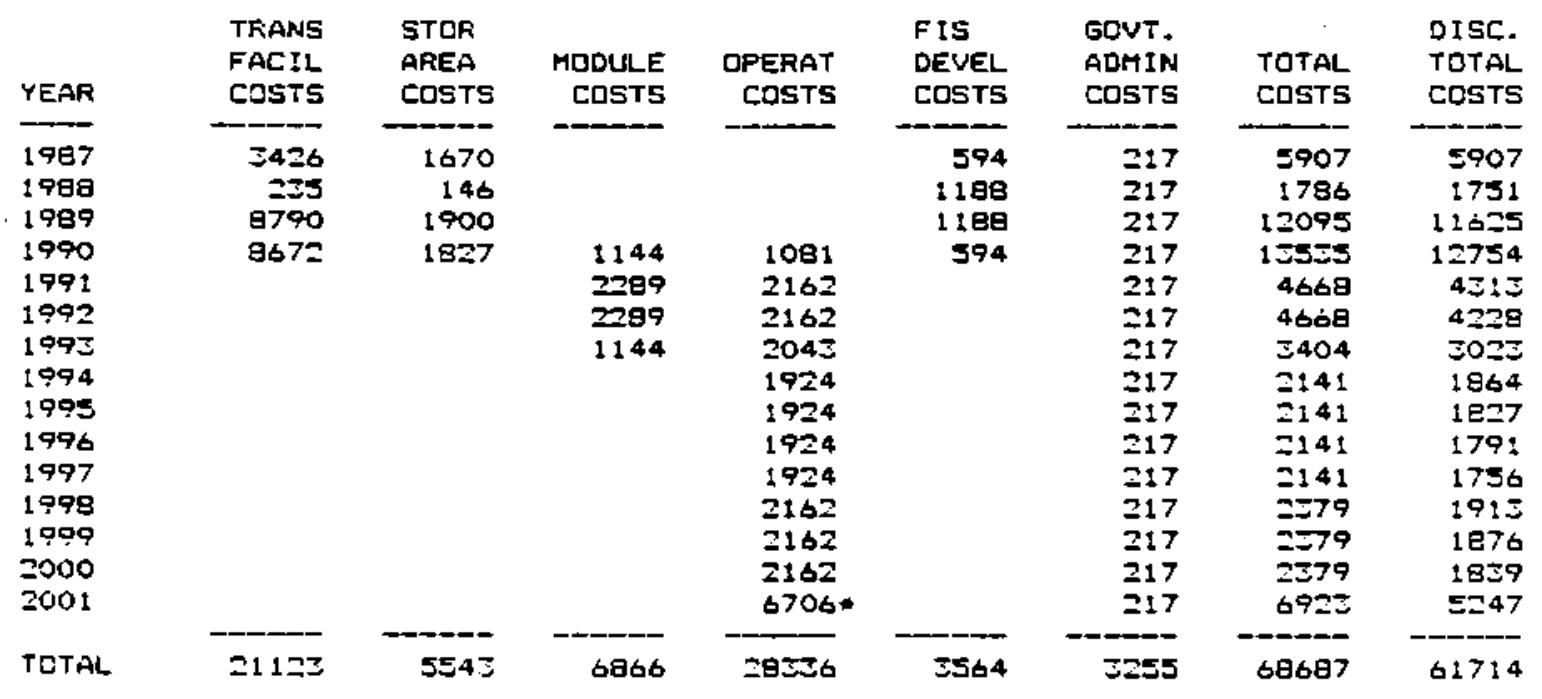

* Decammissianing cost

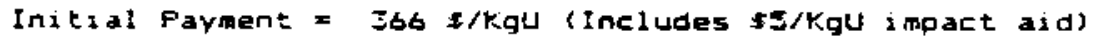

Final Fayment $=290 \mathrm{x} / \mathrm{Kg}$ U (Includes $5: 10 / \mathrm{kg}$ ingact aid) 
TABLE A10-43

COST SEHSITIVITY CASE -- 100\% PWR FUEL

ESTIMATED SPENDING SCMEDULE FOR STORAGE DF 4121 DFYWELLS ( AT GOUEKNMENT SITE WITHOUT EXISTING FACILITIES

$(1000,1997)$

\begin{tabular}{|c|c|c|c|c|c|c|c|c|}
\hline YEAR & $\begin{array}{l}\text { TRANS } \\
\text { FACIL } \\
\text { COSTS }\end{array}$ & $\begin{array}{l}\text { STDR } \\
\text { AREA } \\
\text { COSTS }\end{array}$ & $\begin{array}{r}\text { MLDULE } \\
\text { COSTS }\end{array}$ & $\begin{array}{r}\text { OPEFAT } \\
\text { COSTS }\end{array}$ & $\begin{array}{l}\text { FIS } \\
\text { DEVEL } \\
\text { COSTS }\end{array}$ & $\begin{array}{l}\text { GOVT. } \\
\text { ADMIN } \\
\text { CaST5 }\end{array}$ & $\begin{array}{l}\text { TOTAL } \\
\text { COSTS }\end{array}$ & $\begin{array}{l}\text { DISC. } \\
\text { TOTAL } \\
\text { COSTS }\end{array}$ \\
\hline $\begin{array}{l}1987 \\
1980 \\
1989 \\
1990 \\
1991 \\
1992 \\
1995 \\
1994 \\
1995 \\
1996 \\
1997 \\
1990 \\
1999 \\
2000 \\
2001\end{array}$ & $\begin{array}{r}3476 \\
275 \\
6790 \\
0673\end{array}$ & $\begin{array}{r}2095 \\
146 \\
3 \pm 10 \\
2237\end{array}$ & $\begin{array}{l}17=74 \\
54548 \\
54542 \\
17574\end{array}$ & $\begin{array}{c}7700 \\
7400 \\
7400 \\
5259 \\
7 ! 38 \\
5158 \\
3150 \\
5150 \\
7400 \\
7400 \\
7400 \\
26711\end{array}$ & $\begin{array}{r}594 \\
1198 \\
1189 \\
594\end{array}$ & $\begin{array}{l}849 \\
849 \\
849 \\
849 \\
849 \\
949 \\
849 \\
949 \\
849 \\
849 \\
849 \\
849 \\
949 \\
849 \\
849\end{array}$ & $\begin{array}{r}69 t 2 \\
2418 \\
14137 \\
34 Z 26 \\
4=797 \\
4=797 \\
23592 \\
3987 \\
3997 \\
3987 \\
3987 \\
8249 \\
9249 \\
8249 \\
27560\end{array}$ & 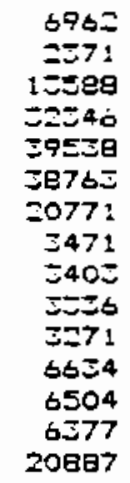 \\
\hline TUTAL & $21: 25$ & 9796 & $10 \Xi_{644}$ & 852ב2 & 3564 & $127 \geq 5$ & 255094 & 208222 \\
\hline
\end{tabular}

* - Decomissioning cost

Initial Paymant = $72 \mathrm{~s} / \mathrm{Kgl}$ (Includes $54 / \mathrm{kgL}$ impact aid)

Final Payment = J $\mathrm{f} / \mathrm{KgU}$ (Includes te/kigu impact id)

TABLE A10-44

COST SENSITIYITY CASE - 100\% BUR FUEL

ESTIMATEO SPENDING SCHEDULE FUR STORAGE OF 3191 DRYWELLS (1900 MTU) AT GOVERNIENT SITE WITHOUT EXISTING FACILITIES $(5000,1987)$

\begin{tabular}{|c|c|c|c|c|c|c|c|c|}
\hline YEAR & $\begin{array}{l}\text { TRANS } \\
\text { FACIL } \\
\text { COSTS }\end{array}$ & $\begin{array}{l}\text { STDR } \\
\text { AREA } \\
\text { COSTS }\end{array}$ & $\begin{array}{l}\text { MOOLLE } \\
\text { COSTS }\end{array}$ & $\begin{array}{r}\text { DFERAT } \\
\text { COSTS }\end{array}$ & $\begin{array}{l}\text { FIS } \\
\text { DEVEL } \\
\text { COSTS }\end{array}$ & $\begin{array}{l}\text { GOVT. } \\
\text { ADHIN } \\
\text { COSTS }\end{array}$ & $\begin{array}{l}\text { TOTAL } \\
\text { COSTS }\end{array}$ & $\begin{array}{l}\text { DISC. } \\
\text { TOTAL } \\
\text { CLSTS }\end{array}$ \\
\hline $\begin{array}{l}1997 \\
1998 \\
1999 \\
1990 \\
1991 \\
1992 \\
1097 \\
1904 \\
1999 \\
1996 \\
1997 \\
1999 \\
1999 \\
2000 \\
2001\end{array}$ & $\begin{array}{r}3426 \\
275 \\
6790 \\
9672\end{array}$ & $\begin{array}{r}2070 \\
146 \\
3260 \\
3197\end{array}$ & $\begin{array}{l}21759 \\
4=518 \\
45519 \\
21759\end{array}$ & $\begin{array}{l}5757 \\
7513 \\
7513 \\
5392 \\
5251 \\
3551 \\
3751 \\
5251 \\
7513 \\
7513 \\
7513 \\
32070\end{array}$ & $\begin{array}{r}594 \\
1199 \\
1189 \\
594\end{array}$ & $\begin{array}{l}949 \\
849 \\
849 \\
949 \\
849 \\
949 \\
949 \\
940 \\
849 \\
949 \\
949 \\
949 \\
949 \\
949 \\
949\end{array}$ & $\begin{array}{r}6947 \\
2418 \\
14087 \\
39818 \\
51990 \\
51890 \\
27990 \\
4100 \\
4100 \\
4100 \\
4100 \\
8562 \\
9362 \\
8562 \\
32919\end{array}$ & $\begin{array}{r}6947 \\
2571 \\
1=540 \\
36579 \\
47929 \\
46989 \\
24854 \\
3569 \\
\vdots 499 \\
\vdots 451 \\
565 \\
6725 \\
6593 \\
6464 \\
=4949\end{array}$ \\
\hline TOTAL & $2112=$ & $867 \mathrm{I}$ & $1 \geq 0534$ & 91778 & 7564 & 12735 & 268475 & $2=7901$ \\
\hline
\end{tabular}

* - Decommissioning cost

Initial Payment $=$ Bt $x / k g U$ (Includes $\$ 5 / k g U$ impact aid)

Final Fayment $=57 \mathrm{~s} / \mathrm{KgU}$ (Includes $59 / \mathrm{Kgl}$ impact aid) 
TABLE A10-45

COST SENSITIVITY CASE -- 100\% PWR FUEL

ESTIMATED SFENDING SCHEDULE FLR STORAGE OF 217 DRYWELLS ( 100 MTU) AT GDVERNMENT SITE WITH EXISTING FACILITIES $(\$ 000,1987)$

\begin{tabular}{|c|c|c|c|c|c|c|c|c|}
\hline YEAF & $\begin{array}{l}\text { TRANS } \\
\text { FACIL } \\
\text { COSTS }\end{array}$ & $\begin{array}{l}\text { STQR } \\
\text { AREA } \\
\text { COSTS }\end{array}$ & $\begin{array}{l}\text { MODULE } \\
\text { COSTS }\end{array}$ & $\begin{array}{r}\text { QPERAT } \\
\text { COSTS }\end{array}$ & $\begin{array}{l}\text { FIS } \\
\text { DEVEL } \\
\text { COSTS }\end{array}$ & $\begin{array}{l}\text { GDUT. } \\
\text { ADMIN } \\
\text { EOSTS }\end{array}$ & $\begin{array}{l}\text { TDTAL } \\
\text { COSTS }\end{array}$ & $\begin{array}{l}\text { DISC. } \\
\text { TOIAL } \\
\text { CaSTS }\end{array}$ \\
\hline $\begin{array}{l}1997 \\
1990 \\
1989 \\
1990 \\
1991 \\
1992 \\
1993 \\
1994 \\
1995 \\
1996 \\
1997 \\
1998 \\
1999 \\
2000 \\
2001\end{array}$ & $\begin{array}{r}1508 \\
107 \\
5826 \\
5773\end{array}$ & $\begin{array}{r}1690 \\
146 \\
1994 \\
1921\end{array}$ & $\begin{array}{r}910 \\
1810 \\
1810 \\
910\end{array}$ & $\begin{array}{l}1048 \\
2096 \\
2096 \\
1615 \\
1134 \\
1134 \\
1134 \\
1154 \\
2096 \\
2096 \\
2096 \\
40964\end{array}$ & $\begin{array}{r}594 \\
1198 \\
1168 \\
294\end{array}$ & $\begin{array}{l}217 \\
217 \\
217 \\
217 \\
217 \\
217 \\
217 \\
217 \\
217 \\
217 \\
217 \\
217 \\
217 \\
217 \\
217\end{array}$ & $\begin{array}{l}4017 \\
1658 \\
72=5 \\
6463 \\
4132 \\
4132 \\
2742 \\
1351 \\
1=51 \\
1351 \\
1551 \\
2313 \\
2315 \\
2312 \\
4305\end{array}$ & $\begin{array}{l}4017 \\
1625 \\
6944 \\
7975 \\
3817 \\
\$ 742 \\
2455 \\
: 176 \\
1150 \\
1150 \\
1108 \\
1960 \\
1624 \\
1768 \\
5261\end{array}$ \\
\hline TOTAL & 9214 & 5759 & 5459 & 21765 & 3564 & 325s & 49015 & 43855 \\
\hline
\end{tabular}

* Decommissianing cost

Initial Payment $=240 \mathrm{x} / \mathrm{Kgl}$ (Includes $5 \mathrm{~K} / \mathrm{Kgl}$ i mpact aid)

Final Payaunt a 2J $\$ / K g U$ (Ineludes $\$ 10 / \mathrm{Kgll}$ impact aid)

TABLE A10-46

COST SENSITIVITY CASE -2 1002 BUR FUEL

ESTIMATED SPENDING SCHEDLRE FOR STORAGE OF 273 DRYWELLS (100 MTU) AT GOVEFNIENT SITE WITH EXISTING FACILITIES $(\mp 000,1997)$

\begin{tabular}{|c|c|c|c|c|c|c|c|c|}
\hline YEAR & $\begin{array}{l}\text { TRANS } \\
\text { FAEIL } \\
\text { EOSTS }\end{array}$ & $\begin{array}{l}\text { STOR } \\
\text { AREA } \\
\text { COSTS }\end{array}$ & $\begin{array}{l}\text { RODULE } \\
\text { COSTS }\end{array}$ & $\begin{array}{r}\text { QPSATT } \\
\text { COSTS }\end{array}$ & $\begin{array}{l}\text { FIS } \\
\text { DEVEL } \\
\text { COSTS }\end{array}$ & $\begin{array}{l}\text { GOVT. } \\
\text { ADHIN } \\
\text { CDSTS }\end{array}$ & $\begin{array}{l}\text { TQTAL } \\
\text { COSTS }\end{array}$ & $\begin{array}{l}\text { DISC. } \\
\text { TDTAL } \\
\text { CDSTS }\end{array}$ \\
\hline $\begin{array}{l}1987 \\
1998 \\
1989 \\
1990 \\
1991 \\
1992 \\
1993 \\
1994 \\
1995 \\
1996 \\
1997 \\
1990 \\
1999 \\
2000 \\
2001\end{array}$ & $\begin{array}{r}1508 \\
107 \\
3826 \\
3772\end{array}$ & $\begin{array}{r}1695 \\
146 \\
1986 \\
1912\end{array}$ & $\begin{array}{l}1144 \\
2269 \\
2289 \\
1144\end{array}$ & $\begin{array}{l}1052 \\
2103 \\
2103 \\
1622 \\
1141 \\
114: \\
1141 \\
1141 \\
2103 \\
2103 \\
2103 \\
4364\end{array}$ & $\begin{array}{r}594 \\
1198 \\
1198 \\
594\end{array}$ & $\begin{array}{l}217 \\
217 \\
217 \\
217 \\
217 \\
217 \\
217 \\
217 \\
217 \\
217 \\
217 \\
217 \\
217 \\
217 \\
217\end{array}$ & $\begin{array}{l}4014 \\
1650 \\
7217 \\
1692 \\
4609 \\
4609 \\
2992 \\
1 \pm 50 \\
1558 \\
1350 \\
1258 \\
2500 \\
2320 \\
2520 \\
4581\end{array}$ & $\begin{array}{l}4014 \\
1625 \\
6957 \\
8191 \\
4258 \\
4175 \\
2649 \\
1192 \\
1159 \\
1126 \\
1114 \\
1166 \\
1929 \\
1793 \\
5472\end{array}$ \\
\hline TOTAL & 9214 & 5739 & sest & 22117 & 3564 & テニ55 & 50755 & 45400 \\
\hline
\end{tabular}

* Decammisxioning cost

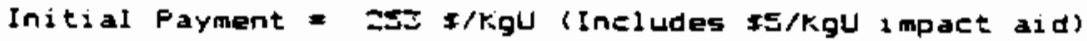

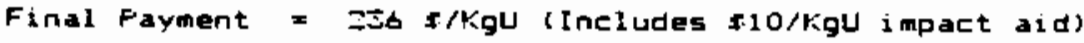


TABLE A10-47

COST SEMSITIYITY CASE - 100\% PWR FUEL

ESTIMATED SFEREING SCHEDULE FUR STORAGE OF 4121 DRYWELLS (1900 MTU) AT GOVERINMENT SITE WITH EXISTING FACILITIES $(5000,1987)$

\begin{tabular}{|c|c|c|c|c|c|c|c|c|}
\hline YEAK & $\begin{array}{l}\text { TRANS } \\
\text { FACIL } \\
\text { COSTS }\end{array}$ & $\begin{array}{l}\text { STDR } \\
\text { AREA } \\
\text { CDSTS }\end{array}$ & $\begin{array}{l}\text { MODULE } \\
\text { COSTS }\end{array}$ & $\begin{array}{r}\text { GPERAT } \\
\text { COSTS }\end{array}$ & $\begin{array}{l}\text { FIS } \\
\text { DEVEL } \\
\text { COSTS }\end{array}$ & $\begin{array}{l}\text { GDVT. } \\
\text { ADHIN } \\
\text { COSTS }\end{array}$ & $\begin{array}{l}\text { TOTAL } \\
\text { COSTS }\end{array}$ & $\begin{array}{l}\text { DISC. } \\
\text { TOTAL } \\
\text { COSTS }\end{array}$ \\
\hline 1987 & 1500 & 2118 & & & 599 & 849 & 5059 & 5069 \\
\hline 1988 & 107 & 146 & & & 1100 & 849 & 2290 & 2245 \\
\hline 1989 & 3826 & ت95 & & & 1199 & 849 & 9258 & $889 \%$ \\
\hline 1990 & 377 & SEבZ & 17274 & 5671 & 594 & 849 & 29483 & 27782 \\
\hline 1991 & & & 34548 & $7=42$ & & 049 & 42739 & $=9484$ \\
\hline 1992 & & & 24548 & 7542 & & 949 & 42739 & SE7:0 \\
\hline 1993 & & & 17274 & 4364 & & 849 & 22687 & 20145 \\
\hline 1994 & & & & 1785 & & 849 & $26 \pm 4$ & $\approx=93$ \\
\hline 1995 & & & & 1785 & & 849 & $2 \leq 54$ & 2248 \\
\hline 1996 & & & & $17 \mathrm{BS}$ & & 849 & $2 \in 54$ & $2=04$ \\
\hline 1907 & & & & 1785 & & 849 & 2654 & 2161 \\
\hline 1998 & & & & 7342 & & 949 & 8191 & 6598 \\
\hline 1999 & & & & 7342 & & 849 & 8191 & 6459 \\
\hline 2000 & & & & 7342 & & 849 & 819: & 652 \\
\hline 2001 & & & & 24368* & & 849 & 25217 & 19111 \\
\hline TOTAL & 9214 & 898: & $10 ₹ 644$ & 76455 & $3 \approx 64$ & 12735 & 214591 & 89730 \\
\hline
\end{tabular}

- Decommisxioning cout

Initial Fayment $=$ ob $t / K g$ J (Includes $54 / \mathrm{KgU}$ impact aid)

Final Payment $=48 \leqslant / K g ل$ (Includes $\$ 7 / K g U$ impact aid)

TABLE A10-48

COST SENSITIVITY CASE -- 100\% BWR FUEL ESTIMATED SPENDING SCHEDULE FDR STDRAGE OF 3191 DRYWELLS (1900 MTU) AT GOVERNITENT SITE WITH EXISTING FACILITIES $( \pm 000,1997)$

\begin{tabular}{|c|c|c|c|c|c|c|c|c|}
\hline YEAR & $\begin{array}{l}\text { TRANS } \\
\text { FACIL } \\
\text { CDSTS }\end{array}$ & $\begin{array}{l}\text { STOR } \\
\text { AREA } \\
\text { COSTS }\end{array}$ & $\begin{array}{l}\text { MODLTE } \\
\text { CDSTS }\end{array}$ & $\begin{array}{r}\text { OPERAT } \\
\text { COSTS }\end{array}$ & $\begin{array}{l}\text { FIS } \\
\text { DEVEL } \\
\text { CDSTS }\end{array}$ & $\begin{array}{l}\text { GOVT. } \\
\text { ADHIN } \\
\text { COSTS }\end{array}$ & $\begin{array}{l}\text { TDTAL } \\
\text { COSTS }\end{array}$ & $\begin{array}{l}\text { DISC. } \\
\text { TOTAL } \\
\text { EDSTS }\end{array}$ \\
\hline $\begin{array}{l}1997 \\
1990 \\
1999 \\
1990 \\
1991 \\
1992 \\
1992 \\
1994 \\
1995 \\
1996 \\
1997 \\
1998 \\
1999 \\
2000 \\
2001\end{array}$ & $\begin{array}{r}1500 \\
107 \\
3826 \\
5775\end{array}$ & $\begin{array}{r}2103 \\
146 \\
345 \\
3272\end{array}$ & $\begin{array}{l}21759 \\
43519 \\
43519 \\
21759\end{array}$ & $\begin{array}{c}3729 \\
7455 \\
7455 \\
4677 \\
1999 \\
1999 \\
1899 \\
1899 \\
7455 \\
7455 \\
7455 \\
29727 *\end{array}$ & $\begin{array}{r}594 \\
1198 \\
1198 \\
594\end{array}$ & $\begin{array}{l}849 \\
849 \\
849 \\
949 \\
849 \\
949 \\
949 \\
849 \\
849 \\
849 \\
949 \\
949 \\
849 \\
849 \\
949\end{array}$ & $\begin{array}{r}5054 \\
2290 \\
9309 \\
53975 \\
51822 \\
51827 \\
27295 \\
2748 \\
2748 \\
2748 \\
2748 \\
8304 \\
9504 \\
8304 \\
30576\end{array}$ & $\begin{array}{r}5054 \\
2745 \\
8050 \\
32015 \\
47876 \\
46957 \\
24229 \\
2502 \\
2345 \\
2=09 \\
2=54 \\
6679 \\
6548 \\
6410 \\
23175\end{array}$ \\
\hline TOTAL & 9214 & Bes & 130554 & $\theta=00 \equiv$ & 3564 & : 27ะ5 & 247936 & $9=14$ \\
\hline
\end{tabular}

* - Decammissioning east

Initial fiayment $=79 \pm / K g U$ (Inclutes $\$ 4 / K g L$ impact aid)

Final Fayment $=32$ \&/KgU (Includes $58 / K g U$ impact aid) 
10.4 IMPACT OF DISCOUN" RATE

The impact of changes to the discount rate used to calculate FIS service charges on FIS costs is shown in Table A10-49.

TABLE A10-49

IMPACT OF DISCOUNT RATE ON FIS SYSTEM COSTS

Discount Rate

New Transfer facility Cases

2: (Base Case)

4:

$6 \%$

Decrease per percent increase in discount rate

Existing Transfer Facility Cases

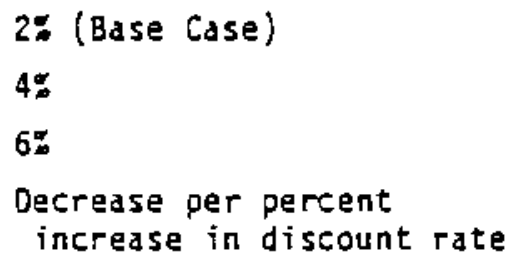

\begin{tabular}{|c|c|c|c|}
\hline \multicolumn{2}{|c|}{$100 \mathrm{MTU}$} & \multicolumn{2}{|c|}{$1900 \mathrm{MTJ}$} \\
\hline $\begin{array}{c}\text { Total } \\
\text { Discounted } \\
\text { Cost }(\$ 000)\end{array}$ & $\begin{array}{c}\text { Total } \\
\text { Unit } \\
\text { Cost }(\mathrm{s} / \mathrm{kgU})\end{array}$ & $\begin{array}{c}\text { Total } \\
\text { Discounted } \\
\text { Cost }(\$ 000)\end{array}$ & $\begin{array}{c}\text { Total } \\
\text { Unit } \\
\text { Cost }(\mathrm{s} / \mathrm{kgu})\end{array}$ \\
\hline
\end{tabular}

$\begin{array}{rrrr}\$ 60,709 & \$ 646 & \$ 218,096 & \$ 131 \\ 55,057 & 607 & 194,757 & 122 \\ 50,342 & 572 & 175,183 & 113 \\ 2,592 & 18.5 & 10,728 & 4.5\end{array}$

$\$ 44,383$
40,077
36,489
1,974

$\$ 478$

$\$ 199,603$

$\$ 121$

177,927

111

159,747

103

9,964

4.5

The estimated spending schedules, discounted annual costs, and the calculation of the Initial and Final Payments for FIS of spent fuel for each of the cases considered in Table A10-49 are set forth in Tables A10-50 through A10-57. 
TABLE A10-50

COST SENSITIVITY CASE -- 4E DISCOUNT RATE

ESTIMATED SPENDING SCHEDULE FOR 5TORAGE OF 2כD DRYWELLS (100 RTU) AT GDVERNMENT SITE WITHQUT EXISTING FACILITIES

$( \pm 000,1987)$

\begin{tabular}{|c|c|c|c|c|c|c|c|c|}
\hline YEAR & $\begin{array}{l}\text { TKANS } \\
\text { FACIL } \\
\text { COSTS }\end{array}$ & $\begin{array}{l}\text { STOK } \\
\text { AREA } \\
\text { COSTS }\end{array}$ & $\begin{array}{l}\text { MODULE } \\
\text { COSTS }\end{array}$ & $\begin{array}{r}\text { OPERAT } \\
\text { COSTS }\end{array}$ & $\begin{array}{l}\text { FIS } \\
\text { DEVEL } \\
\text { COSTS }\end{array}$ & $\begin{array}{l}\text { GOUT. } \\
\text { ADMIN } \\
\text { COSTS }\end{array}$ & $\begin{array}{l}\text { TATAL } \\
\text { COSTS }\end{array}$ & $\begin{array}{l}\text { DISC. } \\
\text { TOTAL } \\
\text { COSTE }\end{array}$ \\
\hline $\begin{array}{l}1987 \\
1998 \\
1999 \\
1990 \\
1991 \\
1992 \\
1995 \\
1994 \\
1995 \\
1996 \\
1997 \\
1999 \\
1999 \\
2000 \\
2001\end{array}$ & $\begin{array}{r}2436 \\
235 \\
8790 \\
9672\end{array}$ & $\begin{array}{r}1671 \\
146 \\
1906 \\
185\end{array}$ & $\begin{array}{r}989 \\
1978 \\
1979 \\
999\end{array}$ & $\begin{array}{l}1080 \\
2159 \\
2159 \\
2040 \\
1971 \\
1921 \\
1921 \\
1921 \\
2159 \\
2159 \\
2159 \\
6523\end{array}$ & $\begin{array}{r}594 \\
1198 \\
1199 \\
594\end{array}$ & $\begin{array}{l}217 \\
217 \\
217 \\
217 \\
217 \\
217 \\
217 \\
=17 \\
217 \\
217 \\
217 \\
217 \\
217 \\
217 \\
217\end{array}$ & $\begin{array}{r}5908 \\
1796 \\
12101 \\
13585 \\
4354 \\
4554 \\
3246 \\
2138 \\
2158 \\
2158 \\
2138 \\
2576 \\
=576 \\
2576 \\
6740\end{array}$ & $\begin{array}{r}5900 \\
1717 \\
11188 \\
11999 \\
5722 \\
5579 \\
2565 \\
1625 \\
1562 \\
1502 \\
1444 \\
1545 \\
1494 \\
1427 \\
5892\end{array}$ \\
\hline TOTAL & 21123 & Isso & 5954 & 2B122 & $\cos 64$ & 3255 & 67554 & $550=$ \\
\hline
\end{tabular}

- Decommissioning east

Initial Payment = $34 Z$ t/KoU (Includes rJ/KgU impact aid)

Final Paymant a $264 \mathrm{~s} / \mathrm{Kgl}$ (Includes $10 / \mathrm{Kgl}$ impact aid)

TABLE A10-5I

COST SENSITIYITY CASE $-6 \%$ OISCOURT RATE

ESTIMATED SFENDING SCHEDULE FOR STORAGE OF 236 DRYWELLS (100 MTU) AT GOVERNIENT SITE WITHOUT EXISTING FACILITIES $(\mp 000,1 \% 87)$

\begin{tabular}{|c|c|c|c|c|c|c|c|c|}
\hline YEAR & $\begin{array}{l}\text { TRANS } \\
\text { FACIL } \\
\text { ECSTS }\end{array}$ & $\begin{array}{l}\text { STOF } \\
\text { AREA } \\
\text { CESTS }\end{array}$ & $\begin{array}{l}\text { HODLEE } \\
\text { COSTS }\end{array}$ & $\begin{array}{r}\text { QPERAT } \\
\text { COSTS }\end{array}$ & $\begin{array}{l}\text { FIS } \\
\text { DEVEL } \\
\text { EOSTS }\end{array}$ & $\begin{array}{l}\text { GDUT. } \\
\text { ADMIN } \\
\text { COSTS }\end{array}$ & $\begin{array}{l}\text { TOTAL } \\
\text { COSTS }\end{array}$ & $\begin{array}{l}\text { DISC. } \\
\text { TOTAL } \\
\text { COSTS }\end{array}$ \\
\hline $\begin{array}{l}1997 \\
1989 \\
1999 \\
1990 \\
1091 \\
1992 \\
1993 \\
1994 \\
1995 \\
1996 \\
1997 \\
2999 \\
1999 \\
2000 \\
2001\end{array}$ & $\begin{array}{r}3426 \\
235 \\
9790 \\
8672\end{array}$ & $\begin{array}{r}1671 \\
146 \\
1906 \\
1837\end{array}$ & $\begin{array}{r}989 \\
1978 \\
1979 \\
989\end{array}$ & $\begin{array}{l}1090 \\
2159 \\
2159 \\
2040 \\
1921 \\
1921 \\
1921 \\
1921 \\
2159 \\
2159 \\
2159 \\
6525\end{array}$ & $\begin{array}{r}594 \\
1188 \\
1188 \\
594\end{array}$ & $\begin{array}{l}217 \\
217 \\
217 \\
217 \\
217 \\
217 \\
217 \\
217 \\
217 \\
217 \\
217 \\
217 \\
217 \\
217 \\
217\end{array}$ & $\begin{array}{r}5908 \\
1786 \\
12101 \\
15 \pm 95 \\
4554 \\
4754 \\
3246 \\
2138 \\
2138 \\
2138 \\
2138 \\
=376 \\
2576 \\
2576 \\
6740\end{array}$ & $\begin{array}{r}5900 \\
1685 \\
10770 \\
11238 \\
3449 \\
3254 \\
2788 \\
1427 \\
1341 \\
1245 \\
1294 \\
1252 \\
1181 \\
1114 \\
2991\end{array}$ \\
\hline TETAL & 21125 & 5556 & $x=54$ & $291=2$ & 5564 & 3255 & 67554 & $50 \pm 42$ \\
\hline
\end{tabular}

* Decdomissianing cost

Initial Payment $=329 t / \mathrm{Kg}$ (Includes $55 / K g U$ impact ald)

Final Fayment $=244 \mathrm{x} / \mathrm{KgU}$ (Includes $510 / \mathrm{kgU}$ impact aid) 
TABLE A10-52

COST SEMSITIVITY CASE - 4Е DISCOUNT RATE

ESTIMATED SFENDING SCHEDULE FOR STORAGE OF 4478 DRYWELLS ( 1900 MTU) AT GOVERNMENT SITE WITHOUT EXISTING FACILITIES

(5.000, 1997)

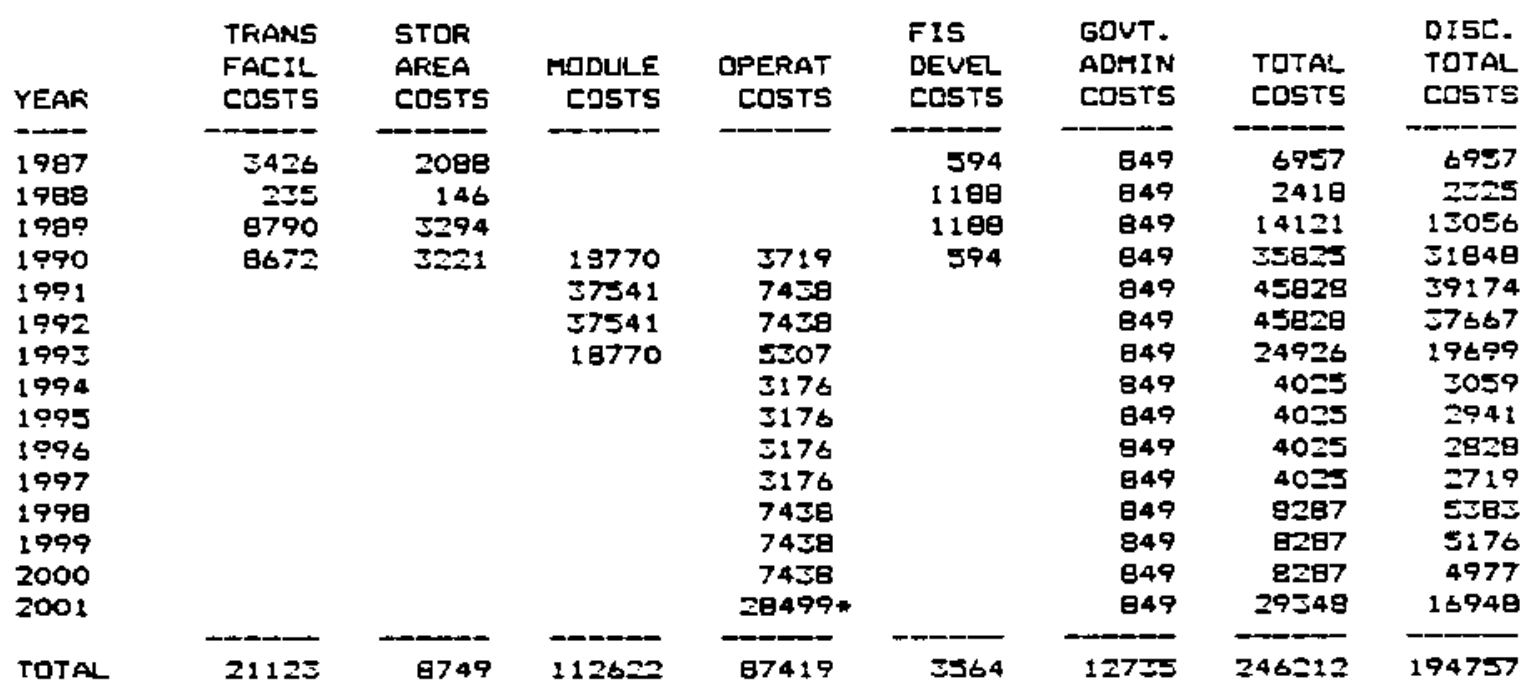

- Decomaissianing cost

Initial Payment $=72$ t/KgU (Includes $54 / \mathrm{Kg}$ impact aid)

Final Fayment $=505 / \mathrm{Kgl}$ (Includes $58 / \mathrm{Kgl}$ impact aid)

TABLE A10-53

COST SENSITIYITY CASE -- 6: DISCOUNT RATE

ESTIMATED SPEPIDING SCHEDULE FOR STORAGE OF 4478 DRYWELLS ( 1900 MTU) AT GOVERNIENT SITE WITHOUT EXISTING FACILITIES

$( \pm 000,1987)$

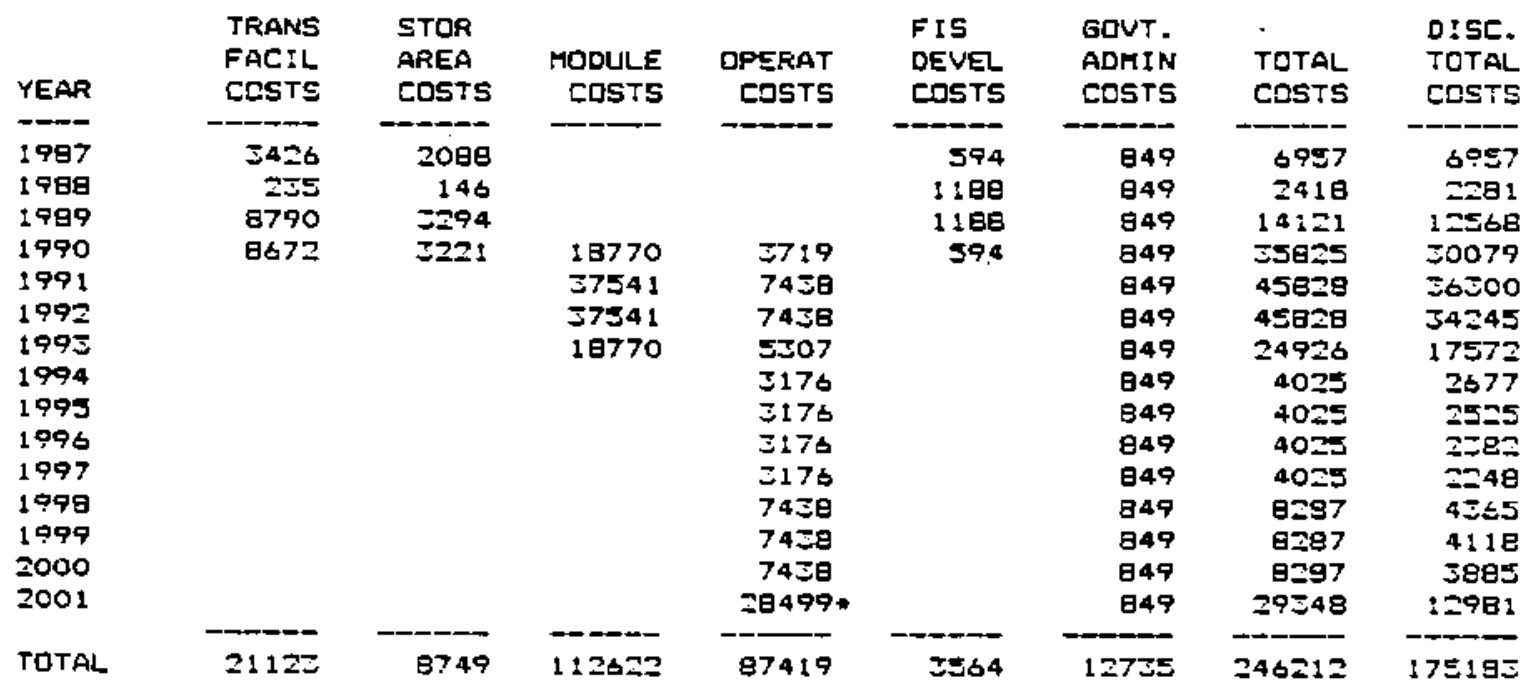

- Deccmmissioning cost

Initial Paynent $=67 \mathrm{~s} / \mathrm{KgU}$ (Includes $54 / K \mathrm{gU}$ impact aid)

Final Paymant $=465 / \mathrm{Kg}$ (Ineludes $58 / \mathrm{Kgl}$ impact aid) 
TABLE $210-54$

COST SENSITIVITY CASE - 4\% OISTCOUNT RATE

ESTIMATED SFENDING SCHEDLLE FOR STORAGE OF $2 \bar{G}$ ORYWELLS (IOD MTU) AT GOVEFNMIENT SITE WITH EXISTING FACILITIES $(5000,1987)$

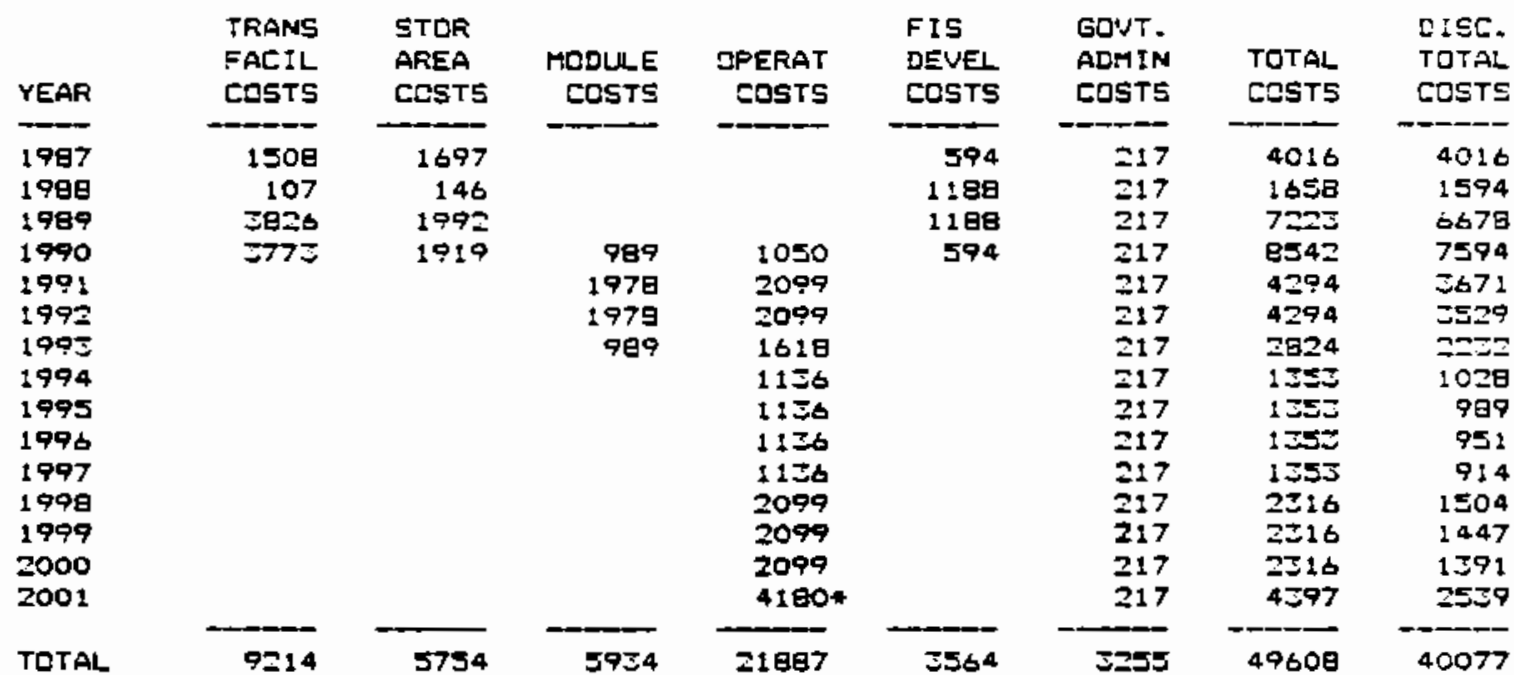

* - Decommisgioning eost

Initial Payamt = 232 s/Kgl (Includes $55 / \mathrm{KgL}$ ingact aid)

Final Payment $=2175 / \mathrm{kgl}$ (Ineludes $* 10 / \mathrm{kgl}$ impact aid)

TABLE A10-55

COST SENSITIVITY CASE -- 6\% OISCOUHT RATE

ESTIMATED SPENDING SCHEDULE FOR STORAGE OF 236 DRYWELLS (100 MTU) AT GOVERNMENT SITE WITH EXISTINIG FACILITIES $(2000,1987)$

\begin{tabular}{|c|c|c|c|c|c|c|c|c|}
\hline YEAR & $\begin{array}{l}\text { TRANS } \\
\text { FACIL } \\
\text { EDSTS }\end{array}$ & $\begin{array}{l}\text { STOF } \\
\text { AREA } \\
\text { CDSTS }\end{array}$ & $\begin{array}{l}\text { MOULE } \\
\text { COSTS }\end{array}$ & $\begin{array}{l}\text { OPERAT } \\
\text { CQSTS }\end{array}$ & $\begin{array}{l}\text { FIS } \\
\text { DEVEL } \\
\text { CDSTS }\end{array}$ & $\begin{array}{l}\text { GOUT. } \\
\text { ADHIN } \\
\text { COSTS }\end{array}$ & $\begin{array}{l}\text { TOTAL } \\
\text { COSTS }\end{array}$ & $\begin{array}{l}\text { DISC. } \\
\text { TOTAL } \\
\text { COSTS }\end{array}$ \\
\hline $\begin{array}{l}1997 \\
1998 \\
1999 \\
1990 \\
1991 \\
1902 \\
1993 \\
1994 \\
1995 \\
1996 \\
1997 \\
1999 \\
1909 \\
2000 \\
2001\end{array}$ & $\begin{array}{r}1500 \\
107 \\
3826 \\
5773\end{array}$ & $\begin{array}{r}1697 \\
146 \\
1992 \\
1919\end{array}$ & $\begin{array}{r}989 \\
1978 \\
1978 \\
989\end{array}$ & $\begin{array}{l}1050 \\
2099 \\
2099 \\
1618 \\
11 \equiv 6 \\
1130 \\
1136 \\
1156 \\
2099 \\
2099 \\
2099 \\
4180\end{array}$ & $\begin{array}{r}594 \\
1188 \\
1198 \\
594\end{array}$ & $\begin{array}{l}217 \\
217 \\
217 \\
217 \\
217 \\
217 \\
217 \\
217 \\
217 \\
217 \\
217 \\
217 \\
217 \\
217 \\
217\end{array}$ & $\begin{array}{l}4016 \\
1658 \\
7223 \\
9542 \\
4 \geq 94 \\
4294 \\
2924 \\
1353 \\
1=52 \\
1=53 \\
1=53 \\
2316 \\
2316 \\
2316 \\
4397\end{array}$ & $\begin{array}{r}4016 \\
1564 \\
6428 \\
7172 \\
3401 \\
3209 \\
1991 \\
900 \\
949 \\
801 \\
756 \\
1=20 \\
1151 \\
1086 \\
1945\end{array}$ \\
\hline TOTAL & $9=14$ & 5754 & 5954 & 21897 & 3564 & 3255 & 49600 & 34499 \\
\hline
\end{tabular}

* - Defommissianing east

\footnotetext{
Initial Fayment $=221 \mathrm{~s} / \mathrm{Kg}$ (Includes $55 / \mathrm{KgU}$ impact aid)

Final Fayment $=20 \Xi t / \mathrm{KgU}$ (Includes $510 / \mathrm{Kgl}$ impact aid)
} 
TABLE A10-56

COST SENSITIVITY CASE - 4\% DISCOUNT RATE

ESTIMATED SPENDING SCHEDULE FOR STORAGE OF 4478 DFYWELLS (1900 MTU)

AT GDVERNMENT SITE WITH EXISTING FACILITIES

$\{1000,1987\}$

\begin{tabular}{|c|c|c|c|c|c|c|c|c|}
\hline YEAR & $\begin{array}{l}\text { TRANS } \\
\text { FACIL } \\
\text { COSTS }\end{array}$ & $\begin{array}{l}\text { STDF } \\
\text { AREA } \\
\text { COSTS }\end{array}$ & $\begin{array}{l}\text { MaDULE } \\
\text { CESTS }\end{array}$ & $\begin{array}{r}\text { QFERAT } \\
\text { COSTS }\end{array}$ & $\begin{array}{l}\text { FIS } \\
\text { DEVEL } \\
\text { COSTS }\end{array}$ & $\begin{array}{l}\text { GOUT. } \\
\text { ADHIN } \\
\text { COSTS }\end{array}$ & $\begin{array}{l}\text { TOTAL } \\
\text { COSTS }\end{array}$ & $\begin{array}{l}\text { DISC. } \\
\text { TDTAL } \\
\text { COSTS }\end{array}$ \\
\hline $\begin{array}{l}1987 \\
1989\end{array}$ & $\begin{array}{r}1509 \\
107\end{array}$ & $\begin{array}{r}2115 \\
140\end{array}$ & & & $\begin{array}{r}594 \\
1198\end{array}$ & $\begin{array}{l}849 \\
849\end{array}$ & $\begin{array}{l}5064 \\
=090\end{array}$ & $\begin{array}{l}5064 \\
2202\end{array}$ \\
\hline 1589 & TE2t & 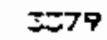 & & & 1188 & 849 & 9242 & e545 \\
\hline 1990 & $377 \Xi$ & 506 & 10770 & $\Xi 6 \% 0$ & 594 & 849 & $20 \% 92$ & 2754 \\
\hline 199: & & & $=7541$ & 7380 & & 849 & 45770 & $30: 24$ \\
\hline 1992 & & & э541 & TకBo & & 849 & 45770 & $376=0$ \\
\hline $199=$ & & & $1 E 7>0$ & 4602 & & 849 & 24221 & 19142 \\
\hline 1994 & & & & $18=3$ & & 849 & 3672 & $20 \pm 1$ \\
\hline 1995 & & & & :922 & & 849 & $2 \in 72$ & 1952 \\
\hline 1996 & & & & 1日ZZ & & 849 & 2672 & 1877 \\
\hline 1997 & & & & 1822 & & 849 & 2672 & 1805 \\
\hline 1990 & & & & 7380 & & 849 & $a=29$ & 545 \\
\hline 1999 & & & & 7300 & & 849 & 8229 & 5140 \\
\hline 2000 & & & & 7380 & & 849 & $8 \geq 39$ & 4942 \\
\hline 2001 & & & & $26150+$ & & 849 & 27005 & 15595 \\
\hline TOTAL & 9214 & 8944 & 112022 & 79640 & 3564 & 12735 & $2=5719$ & 177927 \\
\hline
\end{tabular}

* - Decommiesioning cost

Initial Payaent $=$ to $5 / K g l$ (Includes $54 / K g$ limpact aid)

Final Payment = 45 $5 / \mathrm{Kgl}$ (Ineludes $\$ 7 / \mathrm{Kgl}$ impact aid)

TABLE A10-57

COST SEHSITIVITY CASE - 65 OISCOUNT RATE

ESTIMATED SPENDING SOEDULE FOR STORAGE DF 447B DRYWELLS ( 1900 MTU) AT GOVERNMENT SITE WITH EXISTING FACILITIES $\{\$ 000,1987)$

\begin{tabular}{|c|c|c|c|c|c|c|c|c|}
\hline YEAR & $\begin{array}{l}\text { TRANS } \\
\text { FACIL } \\
\text { CaSTS }\end{array}$ & $\begin{array}{l}\text { STDR } \\
\text { AREA } \\
\text { CDSTS }\end{array}$ & $\begin{array}{l}\text { RODLLE } \\
\text { COSTS }\end{array}$ & $\begin{array}{r}\text { OFERAT } \\
\text { COSTS }\end{array}$ & $\begin{array}{l}\text { FIS } \\
\text { DEVE! } \\
\text { EDSTS }\end{array}$ & $\begin{array}{l}\text { GOVT. } \\
\text { ADHIN } \\
\text { COSTS }\end{array}$ & $\begin{array}{l}\text { TOTAL } \\
\text { COSTS }\end{array}$ & $\begin{array}{l}\text { DISC. } \\
\text { TUTAL } \\
\text { COSTS }\end{array}$ \\
\hline $\begin{array}{l}1997 \\
1980\end{array}$ & $\begin{array}{r}1509 \\
107\end{array}$ & $\begin{array}{r}2115 \\
146\end{array}$ & & & $\begin{array}{r}594 \\
1188\end{array}$ & $\begin{array}{l}849 \\
849\end{array}$ & $\begin{array}{l}5064 \\
2090\end{array}$ & $\begin{array}{l}5064 \\
2160\end{array}$ \\
\hline 1989 & 5日26 & 379 & & & 1188 & 849 & 9242 & 8225 \\
\hline 1990 & $\Xi 775$ & \pm 306 & $1 E 770$ & $\$ 690$ & 594 & 849 & 30982 & 26013 \\
\hline 1991 & & & 57541 & $75 \theta 0$ & & 849 & 45770 & $=6254$ \\
\hline 1992 & & & $=7541$ & $7 \Xi 80$ & & 849 & 45770 & 54302 \\
\hline 1903 & & & 28770 & 4602 & & 849 & 24221 & 17075 \\
\hline 1994 & & & & 1日2: & & 849 & 2672 & 1777 \\
\hline 1995 & & & & $182=$ & & 849 & 2672 & 1676 \\
\hline 1996 & & & & 1825 & & 949 & 2672 & 1582 \\
\hline 1997 & & & & 1823 & & B49 & 2672 & 1492 \\
\hline 1998 & & & & 7580 & & 849 & $B=\geq 9$ & $4=55$ \\
\hline 1999 & & & & T380 & & 849 & $8 \approx 29$ & 4090 \\
\hline 2000 & & & & 7300 & & B49 & 19209 & 3850 \\
\hline 2001 & & & & I6156* & & 849 & 27005 & $1: 9,44$ \\
\hline TITAL & 9214 & 8944 & $1: 2627$ & 78640 & 3564 & 12755 & 205719 & $: 59747$ \\
\hline
\end{tabular}

* - Decomanissianing cost

\footnotetext{
Initial Payment * $61 \mathrm{x} / \mathrm{KgU}$ (Includes $54 / \mathrm{Kgl}$ impact aid)

Final Faymont $=42 \mathrm{~s} / \mathrm{kg}$ ' (Includes $57 / \mathrm{kg}$ i imoact aid)
} 
The impact on FIS costs of not having to license a FIS facility through the NRC is shown in Table AlD-58. In this table the cost impact is shown separately for (i) not having to go through the formal NRC review of a safety analysis report, and hearings on construction and operation, but rather having internal DOE reviews only, (ii) not having to implement NRC security regulations but rather using the security protection afforded the existing site, and (iii) a combination of (i) and ( $i$ ).

TABLE A20-58

IMPACT ON FIS SYSTEM COSTS OF MOT HAYING TO LICENSE FIS FACILITIES

Ner Transfer factility Cases Full NRT Licensing (Base Case)

Ho NRC Licensing Activites

Savings

No NRC Security

Savings

No NRC Licensing or Securtty

Sarings

Existing Transfer Facility Cases

Full NRC Licensing (Base Case)

Mo NRC Licensing Activites

Savings

No NRC Security

Savings

No NRC Licensing or Security

Savings

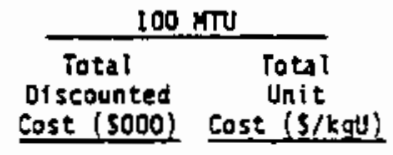

Cost (\$000) Cost (\$/kqu)

$\$ 60,709 \quad \$ 645$

58,881

1,828

53,392

7,317

$5 i, 566$

9,143

$\$ 44,383$

43,347

1,036

37,063

7,320

36,029

8,354

\begin{tabular}{cc}
\multicolumn{2}{c}{1900 MTU } \\
\hline $\begin{array}{c}\text { Total } \\
\text { Discounted }\end{array}$ & $\begin{array}{c}\text { Total } \\
\text { Unit } \\
\text { Cost (S000) }\end{array}$ \\
Cost (S/kgU)
\end{tabular}

$\$ 218,096 \quad \$ 131$

$216,271 \quad 130$

1,825

210,779

7,317

208,957

9,139

$\$ 199,503$

$\$ 121$
5

131
130
1
127
4
126
5

121
120
116
5
115
6

198,567

1,036

192,280

7,323

191,243

8,360

120

1

116

115

90

The estimated spending schedules, discounted annual costs, and the calculation of the Initial and Final Payments for FIS of spent fuel for each of the cases considered in Table A10-58 are set forth in Tables A10-59 through A10-70. 
TABLE ALO-59

COST SENSITIVITY CASE -- NO NRC LICENSING

ESTIMATED SFENDING SCHEDULE FOR STIRAGE OF 236 DRYWELL $(100$ RTU) AT GPVERNASTN SITE WITHOUT EXISTING FACILITIES

$( \pm 000,1987)$

\begin{tabular}{|c|c|c|c|c|c|c|c|c|}
\hline YEAR & $\begin{array}{l}\text { TRARS } \\
\text { FACIL } \\
\text { COSTS }\end{array}$ & $\begin{array}{l}\text { ᄃTaR } \\
\text { AREA } \\
\text { casTs }\end{array}$ & $\begin{array}{l}\text { ACDULE } \\
\text { COSTS }\end{array}$ & $\begin{array}{r}\text { DFERAT } \\
\text { COSTS }\end{array}$ & $\begin{array}{l}\text { FIS } \\
\text { DEVEL } \\
\text { CDSTS }\end{array}$ & $\begin{array}{l}\text { GDUT. } \\
\text { ADMIN } \\
\text { CDSTS }\end{array}$ & $\begin{array}{l}\text { TDTAL } \\
\text { COSTS }\end{array}$ & $\begin{array}{l}\text { OISC. } \\
\text { TOTAL } \\
\text { COSTS }\end{array}$ \\
\hline $\begin{array}{l}1997 \\
1989\end{array}$ & $\begin{array}{r}2961 \\
103\end{array}$ & 920 & & & $\begin{array}{r}594 \\
1198 \\
199\end{array}$ & $\begin{array}{l}=17 \\
=17\end{array}$ & $\begin{array}{r}4704 \\
1570\end{array}$ & $\begin{array}{r}4704 \\
1539 \\
1=97\end{array}$ \\
\hline 1989 & $\begin{array}{l}8724 \\
8 \times 72\end{array}$ & 1864 & & & $\begin{array}{r}1189 \\
594\end{array}$ & $\begin{array}{l}217 \\
217\end{array}$ & 11993 & $\begin{array}{l}115=7 \\
12609\end{array}$ \\
\hline 1991 & & & $\begin{array}{r}759 \\
1979\end{array}$ & $\begin{array}{l}1076 \\
2: 31\end{array}$ & & $\begin{array}{l}217 \\
217\end{array}$ & $4 \Xi 46$ & 4015 \\
\hline 1992 & & & 1978 & $2: 51$ & & 217 & $4 \Xi 4 b$ & 39:36 \\
\hline 1903 & & & 989 & $20 \equiv 2$ & & 227 & ระปด & 2075 \\
\hline 1994 & & & & 1912 & & 217 & 2129 & $185 \bar{Z}$ \\
\hline 19905 & & & & 1912 & & $\therefore 17$ & 2129 & 1817 \\
\hline 1996 & & & & 1712 & & 217 & 21 1 9 & 1781 \\
\hline 1997 & & & & 1912 & & $2: 7$ & 2129 & 1747 \\
\hline : 99 & & & & 2151 & & 217 & 230 & 1904 \\
\hline 1999 & & & & 2151 & & 217 & 2560 & 1867 \\
\hline 2000 & & & & 2151 & & 217 & 2 Z6 & 1日3! \\
\hline 2001 & & & & $6217 *$ & & 227 & $64=4$ & 487t \\
\hline TOTAL & 204 & 4691 & 5954 & 27729 & $\Xi 564$ & 3255 & 656ミ2 & 5ege 1 \\
\hline
\end{tabular}

* - Decammissianing cast

Initial Fayment = 342 t/KgU (Includes $55 / \mathrm{KgU}$ impact aid)

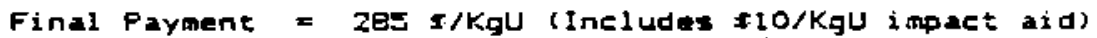

TABLE A10-60

COST SENSITIVITY CASE -

ESTIMATED SPENDING SCHEDLLE FUR STORAEE OF ZJS DRYWELLS (100 MTU) AT GOVERNIENT SITE WITHOUT EXISTING FACILITIES

(5000,19e7)

\begin{tabular}{|c|c|c|c|c|c|c|c|c|}
\hline YEAR & $\begin{array}{l}\text { JRANS } \\
\text { FACIL } \\
\text { CaSTS }\end{array}$ & $\begin{array}{l}\text { STDR } \\
\text { AREA } \\
\text { CDSTS }\end{array}$ & $\begin{array}{r}\text { RCDULE } \\
\text { COSTS }\end{array}$ & $\begin{array}{r}\text { OPERAT } \\
\text { COSTS }\end{array}$ & $\begin{array}{l}\text { FIS } \\
\text { DEVEL } \\
\text { EDSTS }\end{array}$ & $\begin{array}{l}\text { GOUT. } \\
\text { ADHIN } \\
\text { CDSTS }\end{array}$ & $\begin{array}{l}\text { TOTAL } \\
\text { COSTS }\end{array}$ & $\begin{array}{l}\text { DISC. } \\
\text { TOTAL } \\
\text { COSTS }\end{array}$ \\
\hline $\begin{array}{l}1997 \\
1989\end{array}$ & $\begin{array}{r}3426 \\
255\end{array}$ & $\begin{array}{r}1671 \\
146\end{array}$ & & & $\begin{array}{r}594 \\
1180\end{array}$ & $\begin{array}{l}217 \\
217\end{array}$ & $\begin{array}{l}5908 \\
1786\end{array}$ & $\begin{array}{l}5708 \\
1751\end{array}$ \\
\hline 1909 & 2790 & 1906 & & & f & 217 & 12101 & 11651 \\
\hline 1990 & 8672 & 18:T & 989 & 670 & 594 & 217 & 12975 & $12=07$ \\
\hline 1091 & & & 1979 & 1340 & & 217 & 可工 & Ẽob \\
\hline 1092 & & & 1978 & 1340 & & 217 & 3535 & $=202$ \\
\hline 1995 & & & 989 & $1=21$ & & 217 & 2427 & $=155$ \\
\hline 1994 & & & & 1102 & & $3: 7$ & 1319 & 1148 \\
\hline 1905 & & & & $1: 02$ & & 217 & 1319 & 1126 \\
\hline 1996 & & & & 1202 & & 217 & 1319 & 1104 \\
\hline 1997 & & & & $1: 02$ & & 217 & 1319 & 1082 \\
\hline :990 & & & & 1340 & & $2: 7$ & 1557 & $12=2$ \\
\hline 1999 & & & & 1340 & & 217 & : 557 & 1229 \\
\hline 2000 & & & & 1540 & & $2: 7$ & 1557 & 1204 \\
\hline 2001 & & & & $65=$ & & 217 & 6740 & 5108 \\
\hline TOTAL & 2112 & 5556 & 3934 & 19522 & $3 \$ 64$ & 595 & 58954 & 5ะ592 \\
\hline
\end{tabular}

* - Decommissioning cast

\footnotetext{
Initial Fayment $=558$ S/KgU (Inc:udes $55 / k g U$ impact aid)

Final Payment $=200$ s/kgu (Includes $\$ 10 /$ Kgl impact aid)
} 
TABLE ALO-61

COST SENSITIVITY CASE - HO MRC LICENSING OR SECURITY

ESTIMATED SPENDING SCHEDULE FOR STORAGE OF ZZ6 DRYWELLE (100 MTU) AT GQVERNMENT SITE WITHOLT EXISTING FACILITIES

(tooo, 19a7)

\begin{tabular}{|c|c|c|c|c|c|c|c|c|}
\hline YEAR: & $\begin{array}{l}\text { TRANS } \\
\text { FACIL } \\
\text { COSTS }\end{array}$ & $\begin{array}{l}\text { STDR } \\
\text { AREA } \\
\text { CDSTS }\end{array}$ & $\begin{array}{l}\text { MODULE } \\
\text { CDSTS }\end{array}$ & $\begin{array}{r}\text { IPERAT } \\
\text { COSTS }\end{array}$ & $\begin{array}{l}\text { FIS } \\
\text { DEVEl } \\
\text { COSTS }\end{array}$ & $\begin{array}{l}\text { GOVT. } \\
\text { ADMIN } \\
\text { CDETS }\end{array}$ & $\begin{array}{l}\text { TUTAL } \\
\text { COSTS }\end{array}$ & $\begin{array}{l}\text { DISC. } \\
\text { TDTAL } \\
\text { COSTS }\end{array}$ \\
\hline $\begin{array}{l}1997 \\
1968 \\
1989 \\
1990 \\
1991 \\
1992 \\
1993 \\
1994 \\
1995 \\
1996 \\
1997 \\
1990 \\
1999 \\
2000 \\
2001\end{array}$ & $\begin{array}{r}2961 \\
102 \\
8724 \\
9672\end{array}$ & $\begin{array}{r}952 \\
62 \\
1864 \\
1832\end{array}$ & $\begin{array}{r}989 \\
1978 \\
1978 \\
989\end{array}$ & $\begin{array}{l}606 \\
13=2 \\
15=2 \\
1=13 \\
1094 \\
1094 \\
1094 \\
1094 \\
1502 \\
1 \leq 2 \\
1=52 \\
6217 *\end{array}$ & $\begin{array}{r}594 \\
1198 \\
1180 \\
594\end{array}$ & $\begin{array}{l}217 \\
217 \\
217 \\
217 \\
217 \\
217 \\
217 \\
217 \\
217 \\
217 \\
217 \\
217 \\
217 \\
217 \\
217\end{array}$ & $\begin{array}{r}4704 \\
1370 \\
11992 \\
12971 \\
3527 \\
3527 \\
2419 \\
1=11 \\
1311 \\
1311 \\
1311 \\
1549 \\
1549 \\
1549 \\
6454\end{array}$ & $\begin{array}{r}4704 \\
1539 \\
1: 527 \\
12=25 \\
3 \pm 58 \\
5195 \\
2148 \\
1141 \\
1119 \\
1097 \\
1075 \\
1246 \\
1221 \\
1197 \\
4976\end{array}$ \\
\hline TUTAL & 20460 & 4691 & 5934 & $191 \Xi 2$ & 3564 & 3255 & 57036 & 5156 \\
\hline
\end{tabular}

- Decommissioning cast

Initial Payment = 343 s/KqU (Ineludes $\$ 5 / K g U$ impact aid)

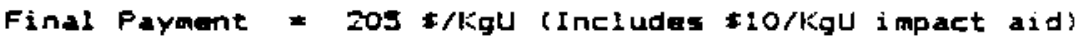

TABLE A10-62

COST SEMSITIVITY CASE - - NO HRC LICEXSING

ESTIMATED SPENDING SCHEDLRE FOR STORAGE DF 447B DRYWELLS ( 1900 MTU) AT GDVERNIENT SITE WITHDUT EXISTING FACILITIES

$(\$ 000,1987)$

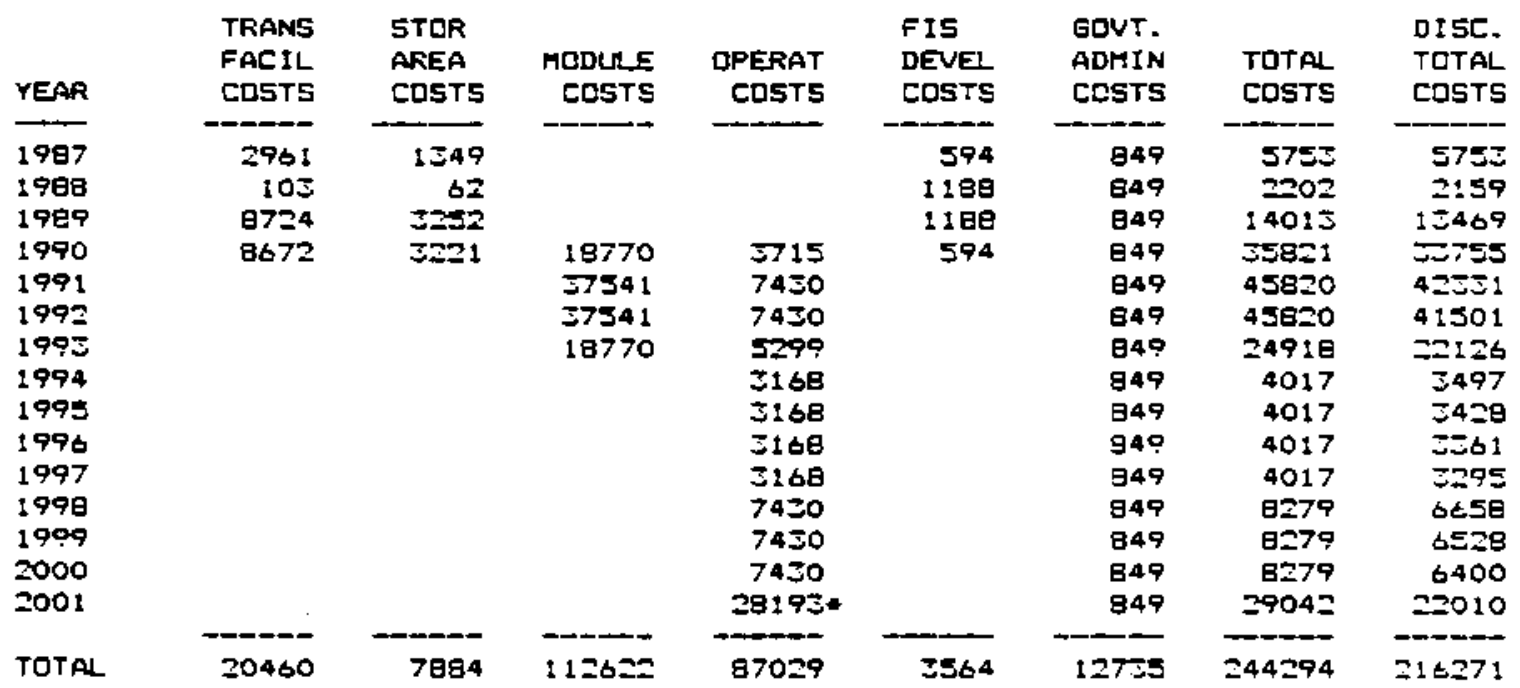

* - Decommissioning cost

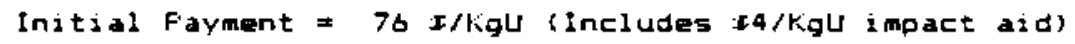

Finai Fayment $=54 \mathrm{~s} / \mathrm{KgL}$ (Includes $5 \mathrm{~g} / \mathrm{Kgl}$ impact aid) 
TABLE A10-63

COST SENSITIVITY CASE -- NO NRC SECURITY

EETIMATED SFENDING SCHEDULE FIR STORAGE IF 4478 DFYWELLS (:700 MTU) AT GOVERNMENT SITE WITHOUT EXISTING FACILITIES

$(9.000,1987)$

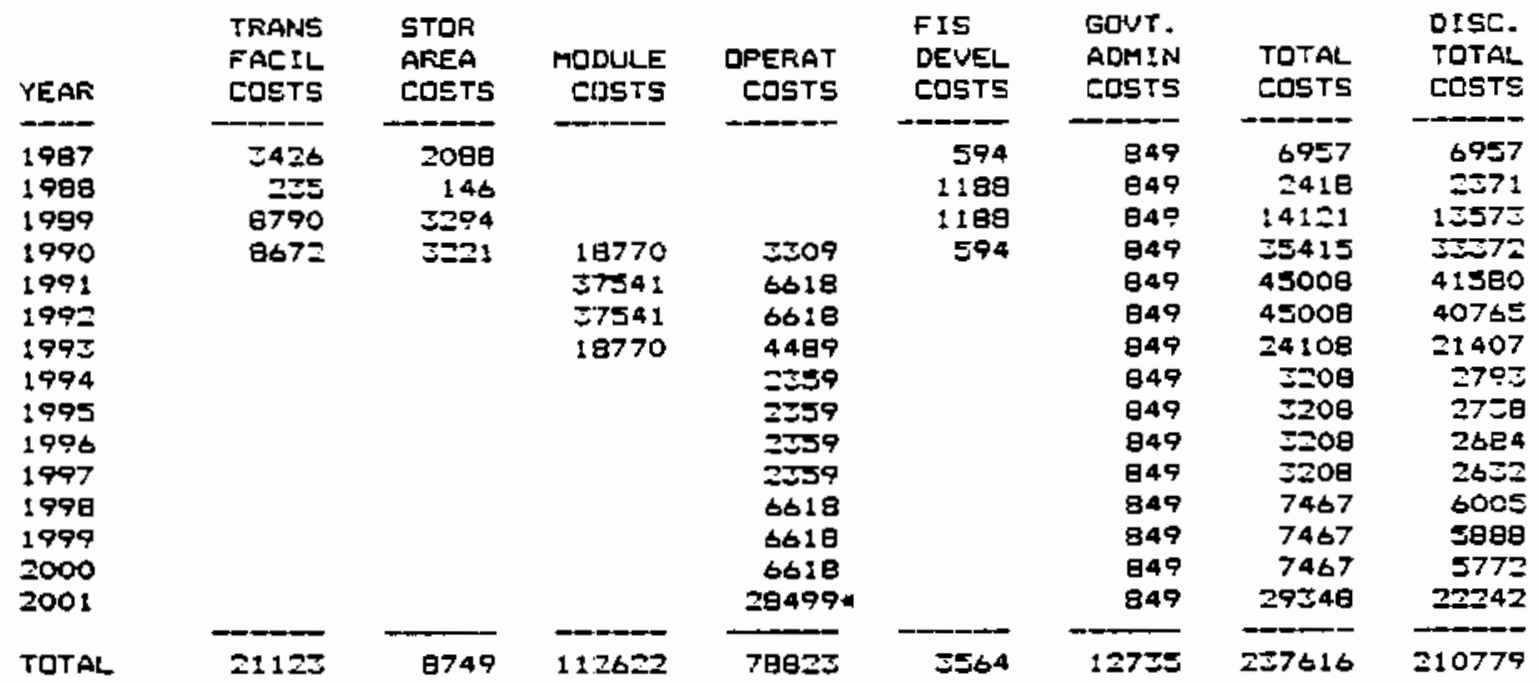

* - Decamissianing cast

Initial Payment $=77+K g ل$ lincludes $54 / K g ل$ impact aid)

Final Payount $=50 \mathrm{t} / \mathrm{KgU}$ (Ineludes $58 / \mathrm{kgl}$ i opact aid)

TABLE A10-64

COST SENSITIVITY CASE -- NO HRC LICENSING OR SECURITY

ESTIMATED SPENDING SCHEDULE FOR STDRAEE DF 4479 DRYWELLS (1900 MTU) AT GOVERNMENT SITE WITHOUT EXISTING FACILITIES

$(x 000,1987)$

\begin{tabular}{|c|c|c|c|c|c|c|c|c|}
\hline YEAR & $\begin{array}{l}\text { TRANS } \\
\text { FACIL } \\
\text { COSTS }\end{array}$ & $\begin{array}{l}\text { STLR } \\
\text { AREA } \\
\text { COSTS }\end{array}$ & $\begin{array}{l}\text { HODURE } \\
\text { COSTS }\end{array}$ & $\begin{array}{r}\text { OPERAT } \\
\text { COSTS }\end{array}$ & $\begin{array}{l}\text { FIS } \\
\text { DEVEL } \\
\text { CISTS }\end{array}$ & $\begin{array}{l}\text { GQUT, } \\
\text { ADMIN } \\
\text { COSTS }\end{array}$ & $\begin{array}{l}\text { TOTAL } \\
\text { COSTS }\end{array}$ & $\begin{array}{l}\text { DISC. } \\
\text { TOTAL } \\
\text { COSTS }\end{array}$ \\
\hline $\begin{array}{l}1997 \\
1999 \\
1999 \\
1990 \\
1991 \\
1992 \\
1995 \\
1994 \\
1995 \\
1996 \\
1997 \\
1999 \\
1999 \\
2000 \\
2001\end{array}$ & $\begin{array}{r}2961 \\
103 \\
8724 \\
8672\end{array}$ & $\begin{array}{r}1 \pm+9 \\
62 \\
3=52 \\
3221\end{array}$ & $\begin{array}{l}18770 \\
37541 \\
3754 ! \\
18770\end{array}$ & $\begin{array}{l}505 \\
6610 \\
6610 \\
4481 \\
2=51 \\
2551 \\
2351 \\
2551 \\
6610 \\
6610 \\
6610 \\
28193 *\end{array}$ & $\begin{array}{r}594 \\
1189 \\
1189 \\
594\end{array}$ & $\begin{array}{l}949 \\
949 \\
949 \\
949 \\
949 \\
849 \\
849 \\
849 \\
849 \\
849 \\
849 \\
849 \\
949 \\
849 \\
849\end{array}$ & $\begin{array}{r}5753 \\
5202 \\
14015 \\
55411 \\
43000 \\
45000 \\
24100 \\
5200 \\
5200 \\
3200 \\
5200 \\
7459 \\
7459 \\
7459 \\
39042\end{array}$ & $\begin{array}{r}5753 \\
2: 59 \\
13469 \\
5 \pm 569 \\
41575 \\
40759 \\
21400 \\
2786 \\
5731 \\
2670 \\
2625 \\
5090 \\
5801 \\
5766 \\
=2010\end{array}$ \\
\hline TOTAL & 20460 & 7894 & 113ロล2 & 7845 & 3564 & 12735 & 255698 & 7090 \\
\hline
\end{tabular}

* Decommissioning cost

Initial Payment $=76$ s/Kgl (Ineludes 5.4/kgl impact aiu)

Final Fayment $=50 \times / k g l$ (Includes $5 \theta / k g l$ impact aid) 
TABLE A10-65

COST SENSITIVITY CASE -- NO NRC LICENSING

SSTIMATED SFENDING SCHEDULE FOR STORALE QF ZZ6 DRYWELLS (:OO MTU)

AT GOVERNMENT SITE WITH EXISTING FACILITIES

$(\$ 000,1997)$

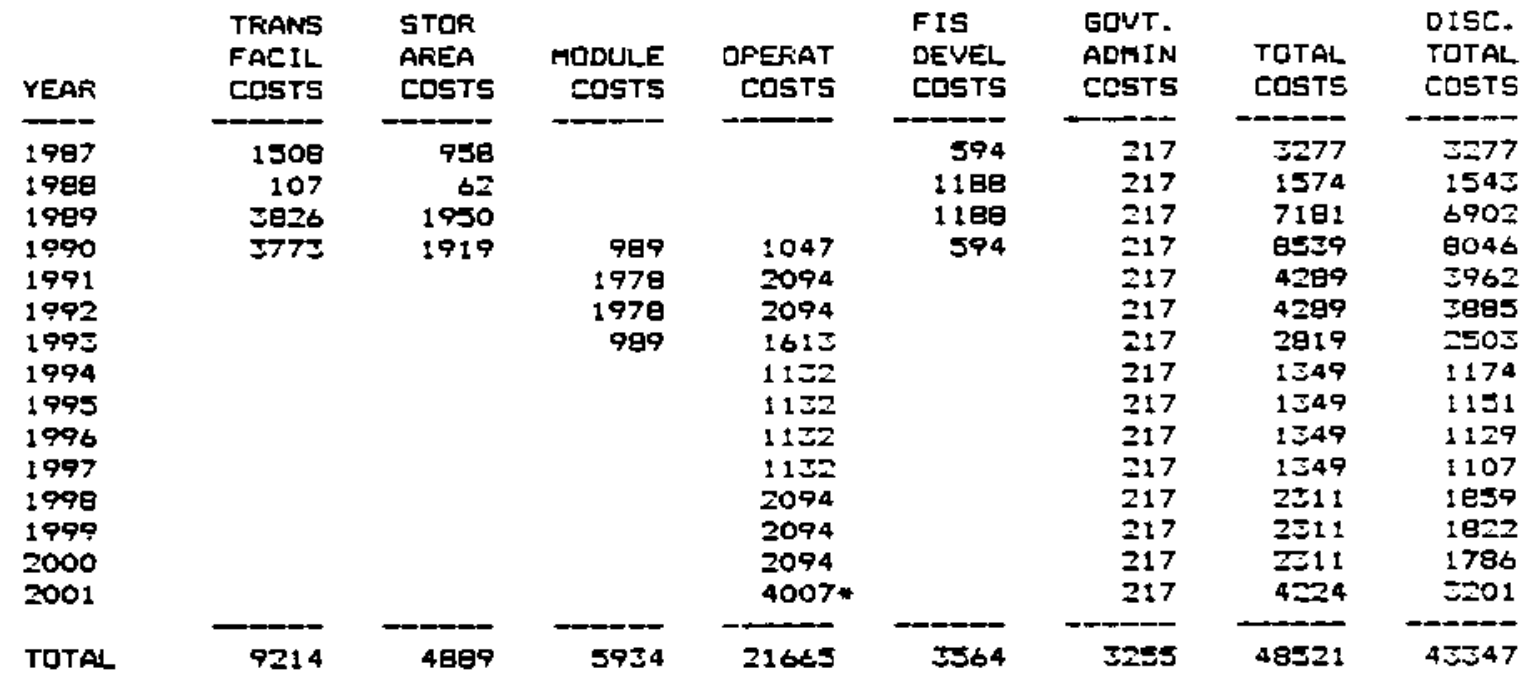

* - Decomaissioning cost

Initial Payment = 2Jo $5 / \mathrm{Kg}$ (Ingludes $55 / \mathrm{Kg}$ impact aid)

Final Payment = 252 s/KgU (Includes $510 / \mathrm{Kgl}$ impact aid)

TABLE A10-66

COST SENSITIVITY CASE $~$ MO NRC SECURITY

ESTIMATED SPENDING SCHEDULE FUR STORAGE OF ZJo DRYWELLS (100 RTU) AT GOVERNIENT SITE WITH EXISTING FACILITIES

$(1000,1997)$

\begin{tabular}{|c|c|c|c|c|c|c|c|c|}
\hline YEAR & $\begin{array}{l}\text { TRANS } \\
\text { FACIL } \\
\text { COSTS }\end{array}$ & $\begin{array}{l}\text { STOR } \\
\text { AREA } \\
\text { COSTS }\end{array}$ & $\begin{array}{r}\text { MDDULE } \\
\text { COSTS }\end{array}$ & $\begin{array}{r}\text { DPERAT } \\
\text { COSTS }\end{array}$ & $\begin{array}{l}\text { FIS } \\
\text { DEVEL } \\
\text { COSTS }\end{array}$ & $\begin{array}{l}\text { GOVT. } \\
\text { ADHIN } \\
\text { COSTS }\end{array}$ & $\begin{array}{l}\text { TUTAL } \\
\text { CISTS }\end{array}$ & $\begin{array}{l}\text { DISC. } \\
\text { TOTAL } \\
\text { COSTS }\end{array}$ \\
\hline $\begin{array}{l}1987 \\
1998 \\
1999 \\
1900 \\
1991 \\
1992 \\
1993 \\
1994 \\
1995 \\
1996 \\
1997 \\
1990 \\
1999 \\
2000 \\
2001\end{array}$ & $\begin{array}{r}1500 \\
107 \\
2326 \\
577\end{array}$ & $\begin{array}{r}1697 \\
146 \\
1992 \\
1919\end{array}$ & $\begin{array}{r}799 \\
1978 \\
1978 \\
989\end{array}$ & $\begin{array}{r}640 \\
1290 \\
1 \geq 80 \\
709 \\
517 \\
\equiv 17 \\
\equiv 17 \\
\vdots 17 \\
1 \geq 80 \\
1290 \\
1 \geq 80 \\
4180\end{array}$ & $\begin{array}{r}994 \\
1180 \\
1188 \\
594\end{array}$ & $\begin{array}{l}217 \\
217 \\
217 \\
217 \\
217 \\
217 \\
217 \\
217 \\
217 \\
217 \\
217 \\
217 \\
217 \\
217 \\
217\end{array}$ & $\begin{array}{r}4016 \\
1639 \\
7205 \\
8132 \\
5475 \\
5475 \\
2005 \\
534 \\
534 \\
534 \\
534 \\
1497 \\
1497 \\
1497 \\
4397\end{array}$ & $\begin{array}{r}4016 \\
1625 \\
6943 \\
7665 \\
5210 \\
3147 \\
1780 \\
465 \\
456 \\
447 \\
458 \\
1204 \\
1180 \\
1157 \\
2202\end{array}$ \\
\hline TETAL & 9214 & 5734 & 5954 & $1=287$ & 5564 & 3255 & 41008 & $3706=$ \\
\hline
\end{tabular}

* Decommigsioning cost

Initial fayment $=2445 / \mathrm{Kg}$ (Includes $55 / k g U$ impact aid)

Final Fayment $=1 \leqslant 4 \$ / k g u$ (Includes $1: 0 / \mathrm{Kgl}$ impact aid) 
TABLE A10-67

COST SENSITIVITY CASE -- NO NRC LICENSING OR SECURITY

ESTIMATED SPENDIMG SCHEDULE FOR STJRAGE OF ZJ̈ DRYWELS (100 MTU)

AT GOVERNMENT SITE WITH EXISTING FACILITIES

( $\pm 000,1997)$

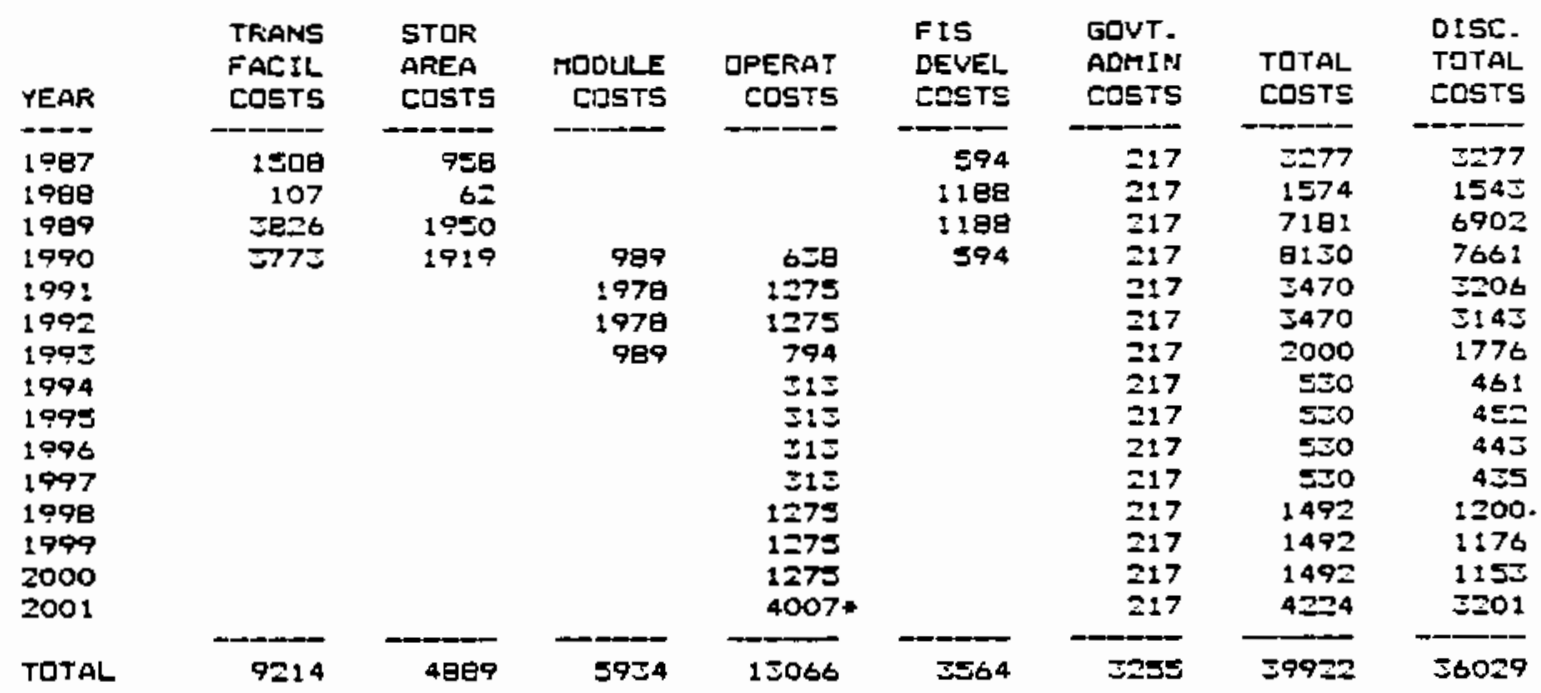

* - Decommissianing coet

Initial Payment = 326. $1 / \mathrm{KgU}$ (Ineludes $15 / \mathrm{Kgl}$ impact aid)

Findi Payment $=132 \$ / K g l$ (Ineludes $\$ 10 / \mathrm{Kgl}$ impact aid)

TABLE A10-68

COST SENSITIVITY CASE - NO NRC LICENSING

ESTIMATED SPENDING SCHEOULE FOR STORAGE OF 4478 DRYWELLS ( 1900 NTU) AT GOVEFNHENT SITE WITH EXISTING FACILITIES

(\$000, 1997)

\begin{tabular}{|c|c|c|c|c|c|c|c|c|}
\hline YEAR & $\begin{array}{l}\text { TFANS } \\
\text { FACIL } \\
\text { COSTS }\end{array}$ & $\begin{array}{l}\text { STOR } \\
\text { AREA } \\
\text { COSTS }\end{array}$ & $\begin{array}{r}\text { RCDULE } \\
\text { CaSTS }\end{array}$ & $\begin{array}{r}\text { QPERAT } \\
\text { COSTS }\end{array}$ & $\begin{array}{l}\text { FIS } \\
\text { DEVEL } \\
\text { EASTS }\end{array}$ & $\begin{array}{l}\text { GDUT. } \\
\text { ADHIN } \\
\text { EDSTS }\end{array}$ & $\begin{array}{l}\text { TOTAL } \\
\text { CLSTS }\end{array}$ & $\begin{array}{l}\text { DISE. } \\
\text { TUTAL } \\
\text { COSTS }\end{array}$ \\
\hline $\begin{array}{l}1987 \\
1980 \\
1909 \\
1990 \\
1991 \\
1992 \\
1993 \\
1994 \\
1995 \\
1996 \\
1997 \\
1996 \\
1999 \\
2000 \\
2001\end{array}$ & $\begin{array}{r}1500 \\
107 \\
=926 \\
2775\end{array}$ & $\begin{array}{r}1374 \\
67 \\
5377 \\
506\end{array}$ & $\begin{array}{l}19770 \\
77941 \\
\div 7541 \\
18770\end{array}$ & $\begin{array}{l}3689 \\
7375 \\
7575 \\
4597 \\
1819 \\
1818 \\
1819 \\
1818 \\
7575 \\
7575 \\
7575 \\
95983\end{array}$ & $\begin{array}{r}574 \\
1298 \\
1189 \\
594\end{array}$ & $\begin{array}{l}849 \\
849 \\
849 \\
849 \\
949 \\
949 \\
849 \\
949 \\
949 \\
849 \\
149 \\
849 \\
849 \\
949 \\
849\end{array}$ & $\begin{array}{r}4375 \\
2=06 \\
9300 \\
30980 \\
45765 \\
45765 \\
24216 \\
2667 \\
2667 \\
2567 \\
2667 \\
8224 \\
1274 \\
9224 \\
268=2\end{array}$ & 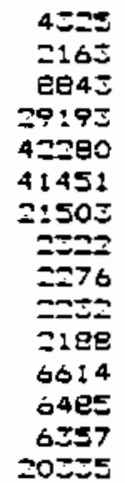 \\
\hline TOTAL & 7214 & 8079 & $11=622$ & 79415 & 5564 & $127 \div 5$ & $=246=9$ & 190567 \\
\hline
\end{tabular}

* Decammissioning cast

Initial Payment $=70 \mathrm{t} / \mathrm{Kgl}$ (Includes $5.4 / \mathrm{Kgl}$ impact aid)

Final Fayment $=50 \mathrm{~s} / \mathrm{kg}$ (Includes $58 / \mathrm{kgll}$ impact aid 
TABLE A10-59

COST SENSITIVITY CASE -- NO NRC SECURITY

ESTIMATED SPENDING SCMEDLLE FIR STORAGE OF 4478 DRYWELLS (1900 MTU)

AT GOVERNRENT SITE WITH EXISTING FACILITIES $(\neq 000,1997)$

\begin{tabular}{|c|c|c|c|c|c|c|c|c|}
\hline YEAR & $\begin{array}{l}\text { TRANS } \\
\text { FACIL } \\
\text { COSTS }\end{array}$ & $\begin{array}{l}\text { STOR } \\
\text { AREA } \\
\text { CDSTS }\end{array}$ & $\begin{array}{l}\text { MODULE } \\
\text { COSTS }\end{array}$ & $\begin{array}{r}\text { OPEFAT } \\
\text { CDSTS }\end{array}$ & $\begin{array}{l}\text { F IS } \\
\text { DEUEL } \\
\text { EDSTS }\end{array}$ & $\begin{array}{l}\text { GDUT. } \\
\text { ADMIN } \\
\text { CDSTS }\end{array}$ & $\begin{array}{l}\text { TOTAL } \\
\text { COSTS }\end{array}$ & $\begin{array}{l}\text { DISC - } \\
\text { TOTAL } \\
\text { CDSTS }\end{array}$ \\
\hline $\begin{array}{l}1997 \\
1998 \\
1999 \\
1990 \\
1991 \\
1992 \\
1993 \\
1994 \\
1995 \\
1996 \\
1997 \\
1999 \\
1999 \\
2000 \\
2001\end{array}$ & $\begin{array}{r}1500 \\
107 \\
=826 \\
5773\end{array}$ & $\begin{array}{r}2119 \\
146 \\
3579 \\
3006\end{array}$ & $\begin{array}{l}18770 \\
37541 \\
37541 \\
18770\end{array}$ & $\begin{array}{c}5=90 \\
6560 \\
6560 \\
5780 \\
1004 \\
1004 \\
1004 \\
1004 \\
6560 \\
6560 \\
6560 \\
26156\end{array}$ & $\begin{array}{r}594 \\
1198 \\
1168 \\
594\end{array}$ & $\begin{array}{l}949 \\
949 \\
949 \\
949 \\
949 \\
949 \\
949 \\
949 \\
949 \\
849 \\
949 \\
849 \\
949 \\
949 \\
949\end{array}$ & $\begin{array}{r}5064 \\
2290 \\
9242 \\
50572 \\
44550 \\
44950 \\
25401 \\
1055 \\
1250 \\
1055 \\
1253 \\
7409 \\
7409 \\
7409 \\
27005\end{array}$ & $\begin{array}{r}5064 \\
2245 \\
9885 \\
28809 \\
41527 \\
40715 \\
20779 \\
1615 \\
1582 \\
1551 \\
1520 \\
5959 \\
5842 \\
5727 \\
20466\end{array}$ \\
\hline TOTAL & 9214 & 8944 & 112622 & 70034 & 3564 & 12735 & $2171: 5$ & $19=200$ \\
\hline
\end{tabular}

- - Decommigsigning cost

Initial Payment $=71+/ \mathrm{KgU}$ (Ineludes $\$ 4 / \mathrm{KgU}$ impact aid)

Final Payment $=43 \mathrm{x} / \mathrm{Kgl}$ (Includes $27 / \mathrm{KgU}$ impact aid)

TABLE A10-70

COST SENSITIVITY CASE -- NO NRC LICENSING OR SECURITY ESTIMATED SPENDINUG SCHEDULE FLR STORAGE OF 447G DRYWELLS ( 1900 MTU) AT GOVERNIENT SITE WITH EXISTING FACILITIES $(\mp 000,1987)$

\begin{tabular}{|c|c|c|c|c|c|c|c|c|}
\hline YEAR & $\begin{array}{l}\text { TRANS } \\
\text { FACIL } \\
\text { COSTS }\end{array}$ & $\begin{array}{l}\text { STDR } \\
\text { AREA } \\
\text { COSTS }\end{array}$ & $\begin{array}{r}\text { MODULE } \\
\text { COSTS }\end{array}$ & $\begin{array}{r}\text { OPERAT } \\
\text { CUSTS }\end{array}$ & $\begin{array}{l}\text { FIS } \\
\text { DEVEL } \\
\text { COSTS }\end{array}$ & $\begin{array}{l}\text { GOUT. } \\
\text { ADMIN } \\
\text { COSTS }\end{array}$ & $\begin{array}{l}\text { TUTAL } \\
\text { COSTS }\end{array}$ & $\begin{array}{l}\text { DISC. } \\
\text { TOTAL } \\
\text { COSTS }\end{array}$ \\
\hline $\begin{array}{l}1997 \\
1988\end{array}$ & $\begin{array}{r}1509 \\
107\end{array}$ & $\begin{array}{r}1374 \\
62\end{array}$ & & & $\begin{array}{r}594 \\
1199\end{array}$ & $\begin{array}{l}849 \\
849\end{array}$ & $\begin{array}{l}4525 \\
7=06\end{array}$ & $\begin{array}{l}4325 \\
2163\end{array}$ \\
\hline 1989 & E826 & $\Xi \Xi \overline{7}$ & & & $11 \mathrm{E \theta}$ & 845 & $9=00$ & EB4: \\
\hline 1990 & $\$ 75$ & 506 & 19770 & 5278 & $\$ 94$ & 849 & 30570 & 29007 \\
\hline 1991 & & & 37541 & 6555 & & 849 & 44945 & $415=2$ \\
\hline 1992 & & & 57341 & 6555 & & 949 & 44945 & 40708 \\
\hline 1993 & & & 18770 & 3777 & & 849 & $Z=390$ & $=0775$ \\
\hline 1994 & & & & 999 & & 849 & 1840 & 1609 \\
\hline 1995 & & & & 999 & & 849 & 1949 & 1577 \\
\hline 1996 & & & & 999 & & 84? & i848 & $: 546$ \\
\hline 1997 & & & & qִִ̣ & & 849 & 1948 & 1516 \\
\hline 1998 & & & & 6555 & & 949 & 7404 & 5955 \\
\hline 1099 & & & & 6555 & & 849 & 7404 & รeこ日 \\
\hline 2000 & & & & 6555 & & 949 & 7404 & $57=4$ \\
\hline 2001 & & & & $25983 *$ & & 849 & $2685=$ & $20=3$ \\
\hline TOTAL & 9214 & 0079 & 112622 & 69809 & $35 b 4$ & 12735 & 216025 & $: 9124 \mathrm{~J}$ \\
\hline
\end{tabular}

* - Decammissioning cost

Instial Payment $=70$ f/Kgl (Includes $\mathbf{1 4 / K g U}$ impact aid)

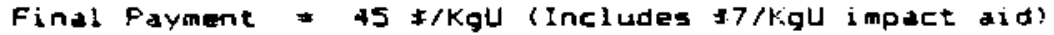


$\therefore$ 
EXHIBIT B

ESTIMATED COSTS FOR TRANSPORT OF SPENT FUEL FROM VARIOUS REACTOR SITES TO FEDERAL INTERIM STORAGE FACILITIES 


\section{EXHIBIT B}

TABLE OF CONTENTS

Page

1.0 CASKS USEO IN STUOY

B1-1

2.0 ESTIMATEO COSTS OF CASK USE ANO SERVICE

B2-1

3.0 FREIGHT COSTS

B3-1

3.1 Truck Tariffs

$83-1$

3.2 Rail Tariffs

3.2.1 Heavy Haul Charges

B3-5

3.2.2 Escort Charges

B3-8

B3-10

4.0 TIME REQUIRED TO EFFECT A SPENT FUEL SHIPMENT

B4-1

5.0 TOTAL COST OF TRANSPORT OF SPENT FUEL TO A FEDERAL

B5-1 INTERIM STORAGE FACILITY 
EXHIBIT B

ESTIMATED COSTS FOR TRANSPORT OF SPENT FUEL FROM VARIOUS

REACTOR SITES TO FEDERAL INTERIM STORAGE FACILITIES

This Exhibit describes the development of the estimated costs of transporting spent fuel between each of twenty-two (22) specific reactor sites that are most likely to require FIS services, and two example locations of FIS facilities, one in the Eastern U.S. and one in the Western U.S. Costs have been developed for both truck transport and for rail transport, although the Oepartment should use rail shipments wherever possible in order to minimize cask handing at FIS facilities -- especially in cases where the FIS storage capacity is above 300 MTU. A summary of the total costs is presented for transport by both truck and rajl shipment between each point of origin and destination.

1.0 CASKS USED IN STUOY

A review was made of the availability and capability of various shipping casks in the United States and it was concluded therefrom that a detemination of the estimated costs associated with transport of spent fuel from reactor sites to the FIS facilities would be made assuming that the NLI $1 / 2$ or IF-300 casks would be used. The bases for this conclusion are set forth below:

(1) Only two types of legal weight truck casks are currently authorized for use in the U.S., the NAC-1/NFS-4 and the NLI $1 / 2$ casks. While there have been NRC licensing problems associated with the NAC-1/NFS-4 casks, no such problems have occurred with the NLI 1/2. Nuclear Assurance Corporation (NAC) has control of all NLI $1 / 2$ casks and NAC-1/NFS-4 casks and has stated that the leasing charges would be about the same for either cask system.

(2) At the present time there is only one rail cask which is both licensed and in current use in the United States. This is the IF-300 cask fabricated by General Electric. One other rail cask, the NLI 10/24, is licensed in the U.S. but is not currently in a usable condition. The others (TN 12 and NAC-3) are in some state of design, construction or are not approved by the NRC. Since the IF-300 now operates in the U.S. and can, therefore, provide current lease charges, it should provide costs which are representative of rail cask transport. 
$\therefore$ 
2.0 ESTIMATED COSTS OF CASK USE AND SERVICE

Estimates of the cask use charge for the NLI $1 / 2$ cask were based on an estimated May 1987 rate schedule developed by NAC for this cask, as follows :

$$
\begin{array}{r}
\text { No. Days of Use } \\
11 \text { - } 10 \text { days } \\
11 \text { - } 30 \text { days } \\
31 \text { - } 90 \text { days } \\
91 \text { - } 180 \text { days } \\
181 \text { - } 365 \text { days }
\end{array}
$$

\section{Charge}

$$
\begin{gathered}
\$ 41,000 \text { (minimum charge) } \\
1,900 / \text { day } \\
1,400 / \text { day } \\
1,000 / \text { day } \\
900 / \text { day }
\end{gathered}
$$

Utilizing this rate schedule and assuming that a cask would be used 300 days/year, a cask use charge of $\$ 1,203 /$ day results. JAI assumed that a $5 \%$ increase in cask use charges would be applicable for 1987 , resulting in a dajly use charge for the NLI 1/2 cask of \$1,263/day (1987 doliars).

General Electric provided a current quotation for the use of the IF300 rail cask which amounted to $\$ 3,500 /$ day. JAI assumed that a $5 \%$ increase in cask use charges would be applicable for 1987 , resulting in a daily use charge for the IF-300 cask of $\$ 3,675 /$ day. 
$\therefore$ 
Freight charges for truck shipments between the various reactors and destinations, excluding escort charges, were determined using published tariffs. Freight charges for rail shipments were calculated using tariff information supplied by the Rockwell Hanford Operations Traffic Department.

\section{$3.1 \quad$ TRUCK TARIFFS}

The cost of shipment of spent fuel by truck consists of several separate charges:

(1) a basic mileage commodity rate for both the loaded and empty cask,

(2) a security charge, and

(3) a vehicle detention charge.

The reference tariff is ICC TRSM 4007-A, dated October 15, 1984. Although originally issued in 1984, Tri-State Motor Transmit Co. (TSMT) has advised that all items in this tariff which are applicable to this study represent current 1986 prices when increased by a $6 \%$ insurance surcharge. JAI recommends, however, increasing the 1986 rates by $5 \%$ to reflect proposed increases in 1987. Therefore, all rates used in this study which were taken from this tariff have been increased from the 1984 published value by $11.3 \%$ in order to provide a reasonable estimation of 1987 rates. The Mileage Commodity Rates are described in Item No, 2000 of the tariff. The rates are based on a cents per 100 pound basis and use a weight of 48,000 lbs for the empty cask and 49,000 lbs. for the loaded truck cask. Table 83-1 sets forth the estimated 1987 Mileage Commodity Rates for the distances pertinent to this study.

A security surveillance charge of $\$ 1.02$ per loaded mile is applicable to the shipment under Iten 810-2 of the tariff. This provides for a guard or second driver to be present in the transport vehicle. A charge of $\$ 0.17$ per mile for the return of personnel is applicable to the return of the empty cask. A charge of $\$ 0.20 / p e r$ loaded mile for arming each driverguard would apply only to shipments through the state of Virginia. 


\section{TABLE B3-1}

\section{RATES FOR TRANSPORT OF NLI $1 / 2$ TRUCK CASK ${ }^{\text {a }}$}

\section{(1987 Dollars)}

\section{Reactor to Destination}

From Surry to Eastern U.S. Site Western U.S. Site

From $\mathrm{Pa}$ isades to Eastern U.S. Site Western U.S. Site

From St. Lucie to Eastern U.S. Site Western U.S. Site

From Robinson to Eastern U.S. Site Western U.S. Site

From Brunswick to Eastern U.S. Site Western U.S. Site

From LaSalle to Eastern U.S. Site Western U.S. Site

From Oconee to Eastern U.S. Site Western U.S. Site

From Peach Bottom to Eastern U.S. Site Western U.S. Site

From Pilgrim to Eastern U.S. Site Western U.S. Site

\begin{tabular}{|c|c|}
\hline Loaded & Empty \\
\hline $\begin{array}{r}\$ 3,98 \\
13.20\end{array}$ & $\begin{array}{r}\$ 2.55 \\
10.00\end{array}$ \\
\hline $\begin{array}{r}4.44 \\
10.68\end{array}$ & $\begin{array}{l}3.01 \\
8.16\end{array}$ \\
\hline $\begin{array}{r}5.14 \\
16.26\end{array}$ & $\begin{array}{r}3.74 \\
12.49\end{array}$ \\
\hline $\begin{array}{r}3.27 \\
16.26\end{array}$ & $\begin{array}{r}1.93 \\
12.49\end{array}$ \\
\hline $\begin{array}{r}4.16 \\
16.00\end{array}$ & $\begin{array}{r}2.75 \\
12.28\end{array}$ \\
\hline $\begin{array}{l}4.06 \\
9.24\end{array}$ & $\begin{array}{l}2.65 \\
7.00\end{array}$ \\
\hline $\begin{array}{r}2.58 \\
13.79\end{array}$ & $\begin{array}{r}1.49 \\
10.61\end{array}$ \\
\hline $\begin{array}{r}5.14 \\
14.29\end{array}$ & $\begin{array}{r}3.74 \\
10.86\end{array}$ \\
\hline $\begin{array}{r}5.90 \\
15.70\end{array}$ & $\begin{array}{r}4.46 \\
12.02\end{array}$ \\
\hline
\end{tabular}




\section{TABLE 83-1 (Continued)}

RATES FOR TRANSPORT OF NLI $1 / 2$ TRUCK CASK ${ }^{\mathrm{a}}$

(1987 Dollars)

Reactor to Destination

From Indian Point to Eastern U.S. Site Western U.S. Site

From Millstone to Eastern U.S. Site Western U.S. Site

From Prairie Island to Eastern U.S. Site Western U.S. Site

From La Crosse to Eastern U.S. Site Western U.S. Site

From Calvert Cliffs to Eastern U.S. Site Western U.S. Site

From Oyster Creek to Eastern U.S. Site Western U.S. Site

From Cooper to

Eastern U.S. Site Western U.S. Site

From Sequoyah to Eastern U.S. Site Western U.S. Site

From Davis Besse to Eastern 0.5. Site Western U.S. Site
Rates in Dollars per 100 Pounds Loaded

Empty

$\$ 6.71$

15.15

$\$ 5.13$

11.56

5.60

4.21

15.44

11.82

6.19

4.67

9.15

6.91

5.42

3.96

8.55

6.44

4.25

2.87

14.29

11.10

4.82

14.87

3.47

11.32

5.71

4.36

7.02

5.39

1.85

1.18

12.64

9.67

4.55

11.21

3.15

8.55

\footnotetext{
${ }^{a}$ Rates based upon Tariff ICC 4007-A, Item 2000, dated October 15, 1984 and escalated by $11.3 \%$ to approximate mid-1987 charges.
} 
In addition to the charges detailed above, demurrage (detention) charges are applicable to each shipment and are covered in Item 500 of the tariff. The following rate schedule provides charges for the time required for loading at origination point and unloading at destination.

\begin{tabular}{cc} 
Hours & Rate Per Hour Per Veh \\
\cline { 2 - 2 } & \\
First 3 & No Charge \\
$4=8$ & $\$ 19.48$ \\
$9-16$ & $\$ 25.04$ \\
$17=24$ & $\$ 30.61$ \\
All Over 24 & $\$ 36.17$
\end{tabular}

The total turnaround time assumed for the NLI $1 / 2$ truck cask, for this study, is 36 hours; 24 hours for loading and 12 hours for unloading. Therefore, the total detention charge, based on the above rate schedule, is $\$ 542.60$ for loading and $\$ 197.56$ for unloading for a total charge of $\$ 740.16 /$ round trip.

Escorts must be provided for each truck shipment as stipulated in 10 CFR Part 73.37. This regulation requires that the transport vehicle, using a pre-determined route, be escorted through each locality designated by the NRC as being a heavily populated urban area. In accordance with this regulation, the escort for a truck shipment is sufficient if the transport vehicle within a heavily populated area is:

(a) Occupied by two individuals, one of whom serves as guard and escorted by an armed member of the local law enforcement agency in a mobile unit of such agency; or

(b) Led by a separate vehicle occupied by a least one anmed escort and trailed by a third vehicle occupied by at least one armed escort.

At the present tine this escort service is provided by local law enforcement agencies in the manner described in (a), above, and is done free of charge. It is believed that as these shipments becone routine some remuneration will be required by these local law enforcement agencies. 
Therefore, for the purposes of this study, the following assumptions and estimates for determination of escort costs have been used:

(1) Each major locality through which the shipment passes will require an escort.

(2) Escorts in each of these Tocalities will be provided by offduty, local police at a charge of $\$ 23.76 / \mathrm{hr}$. per person, including provision of a vehicle.

(3) A minimum of 4 hours will be required for transit from 5 miles outside the locality, through locality, to 5 miles on the other side of the locality.

(4) The labor costs to make the necessary escort arrangements in each locality and the cost of communicating with each locality involved in a shipment (i.e., telephone, mail, telex) was estimated at $\$ 57$.

Taking into consideration the above assumptions and estimated costs, it was estimated that there would be a total cost of $\$ 175$ for escorting a shipment through each locality. This figure includes a $15 \%$ contingency to allow for such possibilities as the need for guards during equipment malfunction or compliance with state laws.

\subsection{RAIL TARIFFS}

Rail freight rates which were effective May 1, 1984 for Class 40 (loaded) and Class $37 \frac{1}{2}$ (empty) rail casks were provided by the Rockwell Hanford Operations Traffic Manager's Office. These rates were increased by 2.42\% (based on the increase in the index for freight for class I railroads from 1984 to that projected by JAI for 1987) to obtain the 1987 vaiues set forth in Table $83-2$. 
TABLE B3-2

RAIL FREIGHT RATES

(1987 Dollars)

Reactor to Destination

$\frac{\text { From Surry to }}{\text { Eastern U.S. Site }}$ Western U.S. Site

From Palisades to Eastern U.S. Site Western U.S. Site

From St. Lucie to Eastern U.S. Site Western U.S. Site

From Robinson to Eastern U.S. Site Western U.S. Site

From Brunswick to Eastern U.S. Site Western U.S. Site

From LaSalle to Eastern U.S. Site Western U.S. Site

From Oconee to Eastern U.5. Site Western U.S. Site

From Peach Bottom to Eastern U.S. Site Western U.S. Site

From Pilgrim to Eastern U.S. Site Western U.S. Site
Rates in Dollars per 100 Pounds

$\begin{array}{cc}\begin{array}{c}\text { Class } 40 \\ \text { Loaded }\end{array} & \begin{array}{c}\text { Class } 37 \frac{1}{2} \\ \text { Empty }\end{array}\end{array}$

$\$ 6.41$

17.67

$\$ 6.01$

16.56

$6.66 \quad 6.25$

13.90

13.03

7.82

18.22

7.33

17.08

$5.38 \quad 5.04$

$17.43 \quad 16.34$

$6.04 \quad 5.65$
7.915

17.91

16.80

6.01

5.63

13.11

12.29

4.70

16.39

4.40

15.36

6.79

6.36

16.99

15.93

9.01

8.45

18.15

17.01 
TABLE B3-2 (Cont inued)

RAIL FREIGHT RATES

(1987 Dollars)

Reactor to Destination

Rates in Dollars per 100 Pounds

From Indian Point to
Eastern U.S. Site
Western U.S. Site

Ciass 40

Loaded

Class $37 y_{2}$

Empty

From Millstone to Eastern U.S. Site Western U.S. Site

$\$ 8.09$

$\$ 7.58$

17.79

16.68

8.60

8.07

18.15

17.01

From Prairie Island to Eastern U.5. Site Western U.5. Site

8.87

8.32

12.46

11.69

From La Crosse to Eastern U.S. Site

8.33

7.80

Western U.S. Site

12.65

11.86

From Calvert $\mathrm{Cl}$ iffs to Eastern U.5. Site

6.55

6.15

Western U.5. Site

17.17

16.10

From Oyster Creek to Eastern U.S. Site Western U.S. Site

7.58

17.67

7.11

16.56

From Cooper to Eastern U.5. Site Western U.S. Site

8.87

8.32

10.84

10.16

From Sequoyah to Eastern U.5. Site Western U.S. Site

$\begin{array}{rr}3.20 & 3.00 \\ 15.26 & 14.31\end{array}$

From Davis Besse to Eastern U.5. Site Western U.S. Site

5.41

14.64

13.72 


\subsubsection{Heavy Haut Charges:}

Heavy haul charges are applicable to this study in the case of ten reactor sites which do not have direct rail access. Also, these charges are assumed to apply in al1 22 cases in which the destination is the Western U.S. facility which is assumed to be without direct rail access. The Eastern U. $S$. site is assumed to have direct rail access.

Heavy haul charges for the ten reactor sites without rail access comprise the following components:

(1) Transport velicle rental (including manpower)

(2) Transfer equipment rental (including manpower)

(3) Overweight permits (if necessary)

A summary of the heavy haul charges between the reactor sites that do not have direct rail access and the corresponding railhead, and between the railhead and the Western U.S. facility, is set forth in Table B3-3. 
TABLE B 3-3

ESTIMATED HEAVY HAUL \& TRANSFER CHARGES PER ROUND TRIP SHIPMENT

OF AN IF-300 RAIL CASK

(1987 Dollars)

Reactor to Raithead/Raithead to Western U.S. FIS Facility

$\begin{array}{ccccc}\begin{array}{c}\text { One-Way } \\ \text { Mijeage }\end{array} & \begin{array}{c}\text { Heavy Haut } \\ \text { Cost }\end{array} & \begin{array}{c}\text { Rigger } \\ \text { Cost }\end{array} & \begin{array}{c}\text { Overweight } \\ \text { Permit } \\ \text { Cost }\end{array} & \begin{array}{c}\text { Total } \\ \text { Cost }\end{array} \\ 35 & \$ 3,987 & \$ 5,780 & \$ 203 & \$ 9,970 \\ 10 & 3,056 & 5,780 & 255 & 9,091 \\ 25 & 3,615 & 5,780 & 80 & 9,475 \\ 10 & 3,056 & 5,780 & 102 & 8,938 \\ 5 & 2,869 & 5,780 & 134 & 8,783 \\ 5 & 2,869 & 5,780 & 156 & 8,805 \\ 25 & 3,615 & 5,780 & 723 & 10,118 \\ 50 & 4,546 & 5,780 & 807 & 11,133 \\ 27 & 3,689 & 5,780 & - & 9,469\end{array}$

Heavy haul cost for round trip of cask is determined as follows:

$2 \times(4$ hrs deadhead time plus 4 hrs loading time plus 4 hrs unloading time, pius transit time a $6 \mathrm{mph}$ ) $\$ 111.79 / \mathrm{hr}$.

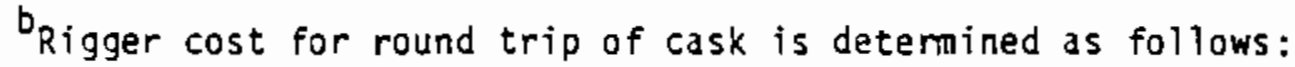

$2 \times(4 \mathrm{hrs}$ deadhead time plus $4 \mathrm{hrs}$ loading/unloading time) a $\$ 160.39 / \mathrm{hr}$, plus a crane charge a $\$ 1,607$ per day, 2 days per round trip.

Cpermits required for cask and for crane for each transfer, Ref. Item 675, ICC Tariff TRSM-4007-A. Tariff values escalated to estimate 1987 charges. 


\subsubsection{Escort Charges}

In accordance with 10 CFR Part 73.37 , each rail shipment of spent fuel must provide (in addition to other provisions) that:

"(1) A shipment car within a heavily populated area is accompanied by two armed escorts (who may be members of a local law enforcement agency), at least one of whom is stationed at a location on the train that will permit observation of the shipment car while in motion.

(2) A shipment car not within any heavily populated area is accompanied by at least one escort stationed at a location on the train that will penit observation of the shipment car while in motion."

Since at this point in time NRC-approved routes cannot be determined (and consequently neither can the number of heavily populated areas), the cost of escort services was estimated on the basis of using two guards for the entire trip. In calculating the escort charge, the cost of equipment, rail fare, subsistence and return airfare was included. 
4.0 TIME REQUIREO TO EFFECT A SPENT FUEL SHIPMENT

Many of the components of the cost of transport of spent fuel are dependent on the time required to effect a round trip shipment, therefore, a detemination was made of the time required to effect a round trip shipment between each of the points of origin and destination being considered in this study.

An estimate was made of the one-way road miles between each reactor and each FIS site considered utilizing the most direct and major routes. The routes selected approximate the shortest distances from the reactors to the FIS sites and represent the route an empty cask would take; a $10 \%$ contingency was added to this distance for a loaded cask to avoid the center of urban areas. The applicable freight charges in each case were detemined using the one-way distances estimated in this manner.

An average travel speed of $35 \mathrm{mph}$ for a truck shipment was assumed for the calculation of the transport time involved. The turnaround time of 36 hours ( 12 hours for unloading and 24 hours for loading the cask) was added to the actual transit time to obtain the total time involved for a round trip shipment. The cask use and service charge and vehicle detention charges were calculated using these time estimates.

Table B4-1 presents the estimated shipping distances involved for truck shipments of spent fuel between the various shipping and receiving locations considered and the estimated time required to complete a round trip shipment. 
TABLE B4-1

DISTANCES AND TIMES REQUIRED FOR COMPLETION OF ROUND TRIP SHIPMENT OF

SPENT FUEL BY NLI $1 / 2$ TRUCK CASK

One-Way Distance
(Miles)

From Surry to

Eastern U.S. Site

Western U.S. Site

From Palisades to

Eastern U.S. Site

Western U.S. Site

From St. Lucie to

Eastern U.S. Site

Western U.S. Site

From Robinson to

Eastern U.S. Site

Western U.S. Site

From Brunswick to Eastern U.S. Site Western U.S. Site

From LaSalle to Eastern U.S. Site Western U.S. Site

From Oconee to

Eastern U.S. Site Western U.S. Site

From Peach Bottom to Eastern U.5. Site Western U.S. Site

From Pilgrim to Eastern U.S. Site Western U.S. Site

$\begin{array}{rrrrrr}565 & 514 & 31 & 36 & 67 & 2.8 \\ 2,320 & 2,109 & 127 & 36 & 163 & 6.8 \\ & & & & & \\ 686 & 624 & 37 & 36 & 73 & 3.0 \\ 1,884 & 1,713 & 103 & 36 & 139 & 5.8 \\ & & & & & \\ 862 & 784 & 47 & 36 & 83 & 3.5 \\ 2,890 & 2,647 & 158 & 36 & 194 & 8.1 \\ & & & & & \\ 384 & 349 & 21 & 36 & 57 & 2.4 \\ 2,875 & 2,614 & 157 & 36 & 193 & 8.0 \\ & & & & & \\ 606 & 551 & 33 & 36 & 69 & 2.9 \\ 2,822 & 2,565 & 154 & 36 & 190 & 7.9 \\ & & & & & \\ 593 & 539 & 32 & 36 & 68 & 2.8 \\ 1,648 & 1,498 & 90 & 36 & 126 & 5.3 \\ & & & & & \\ 210 & 191 & 11 & 36 & 47 & 2.0 \\ 2,450 & 2,227 & 134 & 36 & 170 & 7.1 \\ & & & & & \\ 862 & 784 & 47 & 36 & 83 & 3.5 \\ 2,525 & 2,295 & 138 & 36 & 174 & 7.3 \\ 1,030 & & & & & \\ 2,773 & 2,521 & 151 & 36 & 92 & 3.8 \\ & & & & & 7.8\end{array}$

Time Requirements

\begin{tabular}{|c|c|c|}
\hline $\begin{array}{l}\text { Transport } \\
\text { (Hours) }\end{array}$ & $\begin{array}{l}\text { Turnaround } \\
\text { (Hours) }\end{array}$ & $\begin{array}{c}\text { Total } \\
\text { (Hours) }\end{array}$ \\
\hline
\end{tabular}

2.8

.8

3.0

.8

3

8.1

.4

.0

2.9

7.9

2.8

5.3

2.0

7.1

3.5

.3

3.8

.8 
TABLE B4-1 (Continued)

DISTANCES AND TIMES REQUIRED FOR COMPLETION OF ROUND TRIP SHIPMENT OF

SPENT FUEL $8 Y$ KLI $1 / 2$ TRUCK CASK

Reactor to Destination

One-Way Distance

From Indian Point to

Eastern U.S. Site

Western U.S. Site

- From Millstone to Eastern U.S. Site Western U.S. Site

From Prairie Island to Eastern U.S. Site Western U.S. Site

From La Crosse to Eastern U.S. Site Western U.S. Site

From Calvert Cliffs to Eastern U.S. Site Western U.S. Site

From Oyster Creek to Eastern U.S. Site Western U.S. Site

From Cooper to

Eastern U.S. Site Western U.S. Site

From Sequoyah to Eastern U.S. Site Western U.S. Site

From Davis Besse to Eastern U.S. Site Western U.S. Site

$\frac{\text { (Miles) }}{\text { Loded }}$

1,199

2,663

1,090

2,421

979

2,741

890

2,492

1,098

1,610

998
1,464

926

1,507

842
1,370

641

2,542

583

2,311

718

790

2,639

2,399

1,010

1,243

918

1,130

109

2,240

99
2,036

701

1,980

637
1,800
Time Requirements

\begin{tabular}{ccc}
$\begin{array}{c}\text { Transport Turnaround } \\
\text { (Hours) }\end{array}$ & $\begin{array}{c}\text { Total } \\
\text { (Hours) }\end{array}$ & $\begin{array}{c}\text { Total } \\
\text { (Hours) }\end{array}$ \\
\hline
\end{tabular}

65

145

36

36

101

181

4.2

7.5

53

150

36

36

89

186

3.7

7.8

60

88

36

36

96

124

4.0

5.2

\section{1}

82

\section{6}

36

87

118

3.6

4.9

35

139

36

36

71

175

3.0

7.3

43

144

36

36

79

180

3.3

7.5

\section{5}

68

36

36

91

104

3.8

4.3

6

122

36

36

42

158

1.8

6.6

38

108
36

36
74

144
3.1

6.0

ancludes an allowance of $10 \%$ contingency to avoid center of urban areas but requires escort vehicles around such areas.

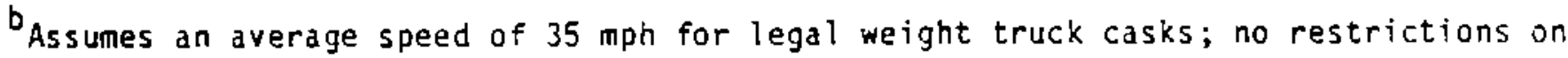
time of operation.

CTurnaround at reactor - loading 24 hours.

Turnaround at destination - unloading 12 hours. 
Rail shipping distances were developed by Pacific Northwest Laboratories (PNL). These distances were detemined as follows:

(1) Rail tariffs for some of the shorter distances were found to contain actual mileages; these were used when available

(2) Where rail tariffs did not show actual distances, a distance equal to 112 percent of the highway mileages was used since PNL determined, that on the average, rail distances were 10-12 percent longer than the corresponding highway distances.

Train speeds vary according to the routing and distance traveled. Estimates of the range of time for rail shipments between specific reactor locations and both the Eastern U.S. site and the Western U.S. site were developed by Rockwell Hanford Operations Traffic Department; the mid point of this range was used for determining the total round trip transport time between points considered in this study.

Table B4-2 presents the estimated shipping distances involved for rail shipments of spent fuel between the various shipping and receiving locations considered and the estimated time required to complete a round trip shipment. 
IABLE B B4-2

OISIANCES AND TIMES REQUIAEO FOR COMPLEIION OF ROUNO TRIP SIIIPHENT OF SPENT FUEL

BY If-300 RAIL CASK

Reactor to Destination

From Surry to

Eastern U.5. Site Western U.S. Site

From palisades to

Eastern U.S. STte

Western U.S. Site

Eastern U.S. Site

Western U.S. Site

From Robinson to

Eastern U.S. Site

Hestern U.S. Site

異
$\dot{1}$
in

From Brunswick to

Eastern U.S. STle

From Lasalle to

Eastern U.S. Site

Hestern U.5. Site

Froun Oconee to

Eastern U.S. Site

Froin Peach Botton to Eastern U.5. Site Western U.S. Site

\begin{tabular}{|c|c|}
\hline $\begin{array}{l}\text { Round Trip } \\
\text { Oistance } \\
\text { (Miles) }\end{array}$ & $\begin{array}{c}\text { Round Trip } \\
\text { Rall Transit } \\
\text { TIune } \\
\text { (llaurs) }\end{array}$ \\
\hline $\begin{array}{l}1,100 \\
4,922\end{array}$ & $\begin{array}{l}193.0 \\
674.3\end{array}$ \\
\hline $\begin{array}{l}1.168 \\
3.402\end{array}$ & $\begin{array}{l}191.5 \\
479.2\end{array}$ \\
\hline $\begin{array}{l}1.558 \\
5,454\end{array}$ & $\begin{array}{l}239.7 \\
673.3\end{array}$ \\
\hline $\begin{array}{r}794 \\
4,664\end{array}$ & $\begin{array}{l}193.7 \\
675.9\end{array}$ \\
\hline $\begin{array}{r}976 \\
5,054\end{array}$ & $\begin{array}{l}191.4 \\
673.9\end{array}$ \\
\hline $\begin{array}{l}1,080 \\
3,170\end{array}$ & $\begin{array}{l}240.0 \\
480.3\end{array}$ \\
\hline $\begin{array}{r}594 \\
4.510\end{array}$ & $\begin{array}{l}191.6 \\
673.1\end{array}$ \\
\hline $\begin{array}{l}1,304 \\
4,660\end{array}$ & $\begin{array}{l}289.8 \\
675.4\end{array}$ \\
\hline
\end{tabular}

\begin{tabular}{|c|c|}
\hline $\begin{array}{c}\text { Round Trip } \\
\text { Heavy Haul } \\
\text { I lave } \\
\text { (llours) }\end{array}$ & $\begin{array}{l}\text { Round } \mathrm{T} \\
\text { lledvy H} \\
\text { Transfer } \\
\text { (llours }\end{array}$ \\
\hline $\begin{array}{l}11.7 \\
20.7\end{array}$ & $\begin{array}{r}8 \\
16\end{array}$ \\
\hline $9 . \overline{0}$ & $\begin{array}{l}0 \\
6\end{array}$ \\
\hline $\begin{array}{r}3.3 \\
12.3\end{array}$ & $\begin{array}{r}8 \\
16\end{array}$ \\
\hline 9.0 & 8 \\
\hline $9 . \overline{0}$ & $\mathrm{~b}$ \\
\hline $9 . \overline{0}$ & \\
\hline $\begin{array}{r}3.3 \\
12.3\end{array}$ & $\begin{array}{r}\theta \\
16\end{array}$ \\
\hline $9 . \overline{0}$ & \\
\hline
\end{tabular}

Turnaround
Tlue
(llours)

Total
Timiee
(llours)

$\begin{array}{ll}356.7 & 14.9 \\ 855.0 & 35.6\end{array}$

335.5

$\begin{array}{ll}335.5 & 14.0 \\ 6.40 .2 & 26.7\end{array}$

395.0

$\begin{array}{lll}144 & 395.0 & 16.5 \\ 144 & 045.6 & 35.2\end{array}$

$144 \quad 337.7$

$144 \quad 036.9 \quad 34.9$

$144 \quad 335.4 \quad 14.0$

$144 \quad 834.9$

$144 \quad 384.0 \quad 16.0$

$114641.3 \quad 66.7$

$\begin{array}{lll}144 & 346.9 & 14.5 \\ 144 & 045.4 & 35.2\end{array}$

$\begin{array}{lll}144 & 433.8 & 18.1 \\ 144 & 836.4 & 34.8\end{array}$


TABLE BQ-2 (Cont InUed)

DISTAHCES AND TIMES REQUIREO FOR COMPLETION OF ROUND IRIP SMIPMENT OF SPENT FUEL GY IF-300 RAIL CASK

\begin{tabular}{|c|c|c|c|c|c|c|c|}
\hline Reactor to Destination & $\begin{array}{l}\text { Round Irip } \\
\text { Difstance } \\
\text { (Miles) }\end{array}$ & $\begin{array}{c}\text { Hound Irlp } \\
\text { Ral1 Yransit } \\
\text { T ine } \\
\text { (llours) }\end{array}$ & $\begin{array}{l}\text { Round Trip } \\
\text { Hleavy Haul } \\
\text { Iline } \\
\text { (llours) }\end{array}$ & $\begin{array}{l}\text { Hound Trip } \\
\text { lleavy Haul } \\
\text { Transfer The } \\
\text { (Hlours) }\end{array}$ & $\begin{array}{l}\text { Turnaround } \\
\text { Time } \\
\text { (llours) }\end{array}$ & $\begin{array}{l}\text { Total } \\
\text { Itane } \\
\text { (llours) }\end{array}$ & $\begin{array}{c}\text { Total } \\
\text { Itme } \\
\text { (10ays) }\end{array}$ \\
\hline 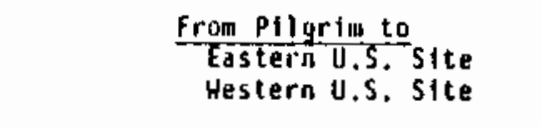 & $\begin{array}{l}2,044 \\
5,210\end{array}$ & $\begin{array}{l}335.1 \\
744.3\end{array}$ & $\begin{array}{r}8.3 \\
17.3\end{array}$ & $\begin{array}{r}80 \\
16\end{array}$ & $\begin{array}{l}144 \\
144\end{array}$ & $\begin{array}{l}495.4 \\
921.6\end{array}$ & $\begin{array}{r}20.6 \\
38.4\end{array}$ \\
\hline $\begin{array}{l}\frac{\text { from } \operatorname{lndtan} \text { polnt to }}{\text { Eastern U.S. Site }} \\
\text { Gestern U.S. Site }\end{array}$ & $\begin{array}{l}1.632 \\
4.910\end{array}$ & $\begin{array}{r}286.3 \\
672.6\end{array}$ & $\begin{array}{r}1.7 \\
10.7\end{array}$ & $\begin{array}{r}8 \\
16\end{array}$ & $\begin{array}{l}144 \\
144\end{array}$ & $\begin{array}{l}440.0 \\
843.3\end{array}$ & $\begin{array}{l}18.3 \\
35.1\end{array}$ \\
\hline $\begin{array}{l}\text { Eroul Hillstone to } \\
\text { Eastern i. S. Site } \\
\text { Hestern u.s. Site }\end{array}$ & $\begin{array}{l}1,812 \\
5,130\end{array}$ & $\begin{array}{l}287.6 \\
675.0 \\
675.0\end{array}$ & $\begin{array}{r}1.7 \\
10.7\end{array}$ & $\begin{array}{c}8 \\
16\end{array}$ & $\begin{array}{l}\begin{array}{l}144 \\
144\end{array} \\
\end{array}$ & $\begin{array}{l}441.3 \\
845.7\end{array}$ & $\begin{array}{l}\frac{18.4}{35.2} \\
35.2\end{array}$ \\
\hline $\begin{array}{l}\text { Froun Prairie lsland to } \\
\text { Eastern U.5. Site } \\
\text { Hestern v.S. Site }\end{array}$ & $\begin{array}{l}1.758 \\
2.624\end{array}$ & $\begin{array}{r}240.8 \\
410.0\end{array}$ & 9.0 & $\begin{array}{l}0 \\
8\end{array}$ & $\begin{array}{l}144 \\
144\end{array}$ & $\begin{array}{l}384.8 \\
571.0\end{array}$ & $\begin{array}{l}16.0 \\
23.8\end{array}$ \\
\hline $\begin{array}{l}\text { Fram La crosse to } \\
\text { Ėastern U.S. SITte } \\
\text { Hestern U.S. Site }\end{array}$ & $\begin{array}{l}1,584 \\
2,724\end{array}$ & $\begin{array}{l}\begin{array}{r}240.0 \\
406.6\end{array} \\
4\end{array}$ & 9.0 & $\begin{array}{l}0 \\
\mathrm{a}\end{array}$ & $\begin{array}{l}144 \\
144\end{array}$ & $\begin{array}{l}384.0 \\
567.6\end{array}$ & $\begin{array}{l}16.0 \\
23.7\end{array}$ \\
\hline $\begin{array}{l}\text { Fron Calvert Clyffs to } \\
\text { Eastern U.S. Site } \\
\text { Hestern U.S. Site }\end{array}$ & 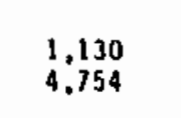 & $\begin{array}{l}\begin{array}{l}191.5 \\
669.6\end{array} \\
6.969 .6\end{array}$ & $\begin{array}{l}16.7 \\
25.7\end{array}$ & $\begin{array}{r}8 \\
16\end{array}$ & $\begin{array}{l}144 \\
1144\end{array}$ & $\begin{array}{l}360.2 \\
855.3\end{array}$ & $\begin{array}{l}15.0 \\
35.6\end{array}$ \\
\hline $\begin{array}{l}\text { From oyster Creek to } \\
\text { Éastiern U.S. Sifte } \\
\text { Hestern U.S. Site }\end{array}$ & 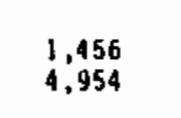 & $\begin{array}{l}\begin{array}{l}338.7 \\
6699.5\end{array} \\
6\end{array}$ & $\begin{array}{r}8.3 \\
17.3\end{array}$ & $\begin{array}{r}8 \\
16\end{array}$ & $\begin{array}{l}144 \\
144\end{array}$ & $\begin{array}{l}399.0 \\
846.8\end{array}$ & $\begin{array}{l}\begin{array}{l}16.6 \\
35.3\end{array} \\
0\end{array}$ \\
\hline $\begin{array}{l}\text { From cooper to } \\
\text { Eastern U.S. Site } \\
\text { Hestern U.S. Site }\end{array}$ & $\begin{array}{l}1,800 \\
2,292\end{array}$ & $\begin{array}{l}\begin{array}{l}240.0 \\
409.3\end{array} \\
4\end{array}$ & 9.0 & $\begin{array}{l}0 \\
8\end{array}$ & $\begin{array}{l}144 \\
144\end{array}$ & $\begin{array}{l}384.0 \\
570.3\end{array}$ & $\begin{array}{l}16.0 \\
23.8\end{array}$ \\
\hline 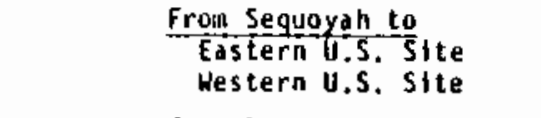 & $\begin{array}{r}2344 \\
4,074\end{array}$ & $\begin{array}{l}117.0 \\
667.9\end{array}$ & 9.0 & $\stackrel{0}{8}$ & $\begin{array}{l}144 \\
144\end{array}$ & $\begin{array}{l}261.0 \\
828.9\end{array}$ & $\begin{array}{l}10.9 \\
34.5\end{array}$ \\
\hline $\begin{array}{l}\text { Froun Odvis Besse to } \\
\text { Eastern U.S. Site } \\
\text { Hestern U.S. Site }\end{array}$ & $\begin{array}{l}1.84 \\
3.824\end{array}$ & $\begin{array}{l}190.4 \\
478.0\end{array}$ & 9.0 & 0 & $\begin{array}{l}144 \\
144\end{array}$ & $\begin{array}{l}334.4 \\
639.0\end{array}-100$ & $\begin{array}{l}13.9 \\
26.6\end{array}$ \\
\hline
\end{tabular}


5.0 TOTAL COST OF TRANSPORT OF SPENT FUEL TO A FEDERAL INTERIM STORAGE

\section{FACILITY}

The total estimated costs of transporting spent fuel from 22 specific reactors to two typical locations are shown in the following tables. Tabie 85-1 details those costs which can reasonably be expected to be incurred when transporting spent fuel by truck. Table $85-2$ shows the estimates of the total cost of transporting spent fuel by rail. Both of these tables have been compiled utilizing the assumptions outlined in Sections 1.0 through 4.0 of this Exhibit 3. 
IABLE Q 85-1

ESIIMATED COSIS OF TRUCK SIIIPHENT OF SPEMI MUCLEAR FUEL

(1987 Dollars)

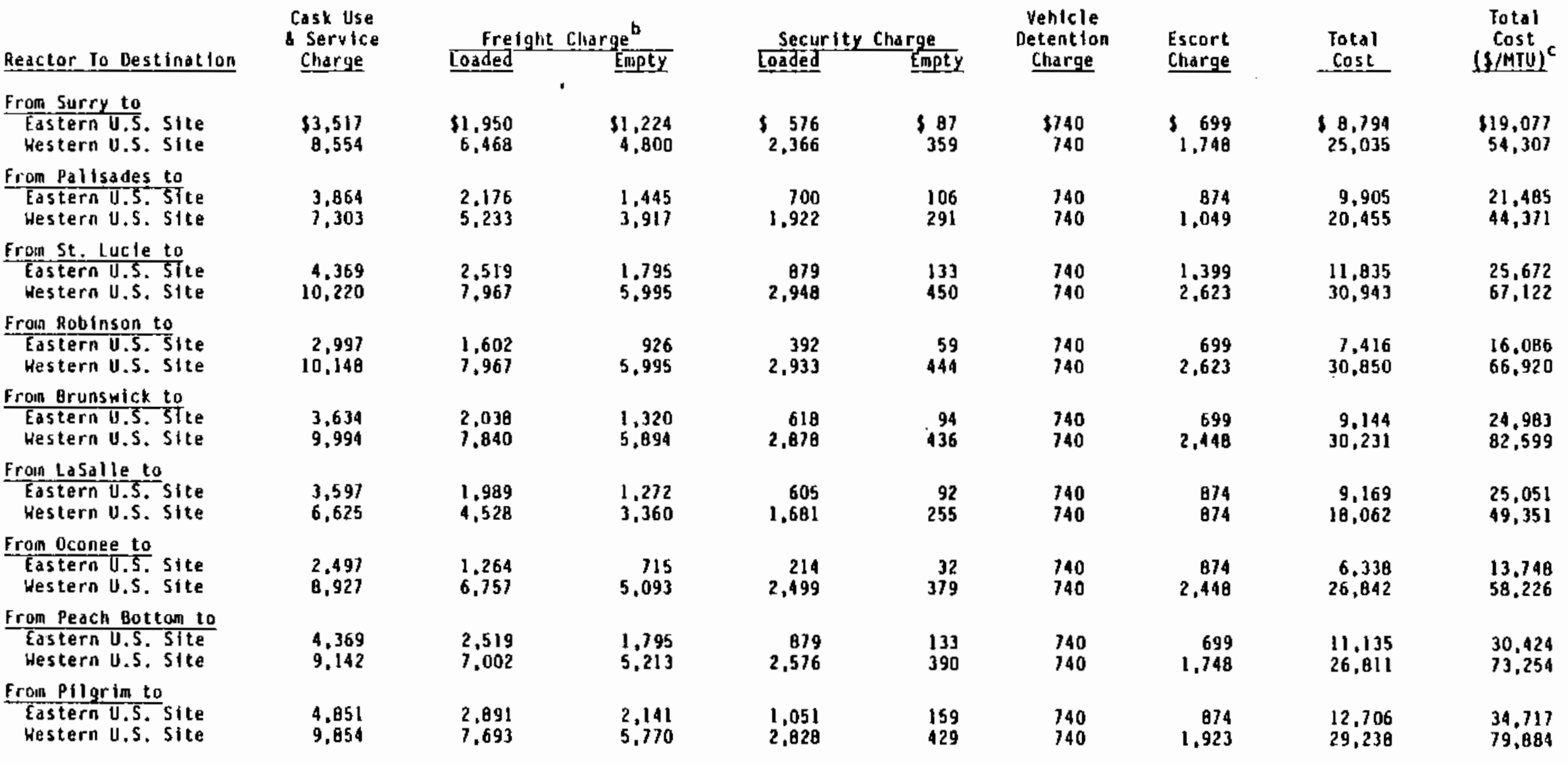


JABLE B5-1 (Continued)

ESTIMATED COSIS OF IRUCK SIIIPHEMI OF SPEHT NUCLEAR FUEL ${ }^{d}$

(1987 Dollars)

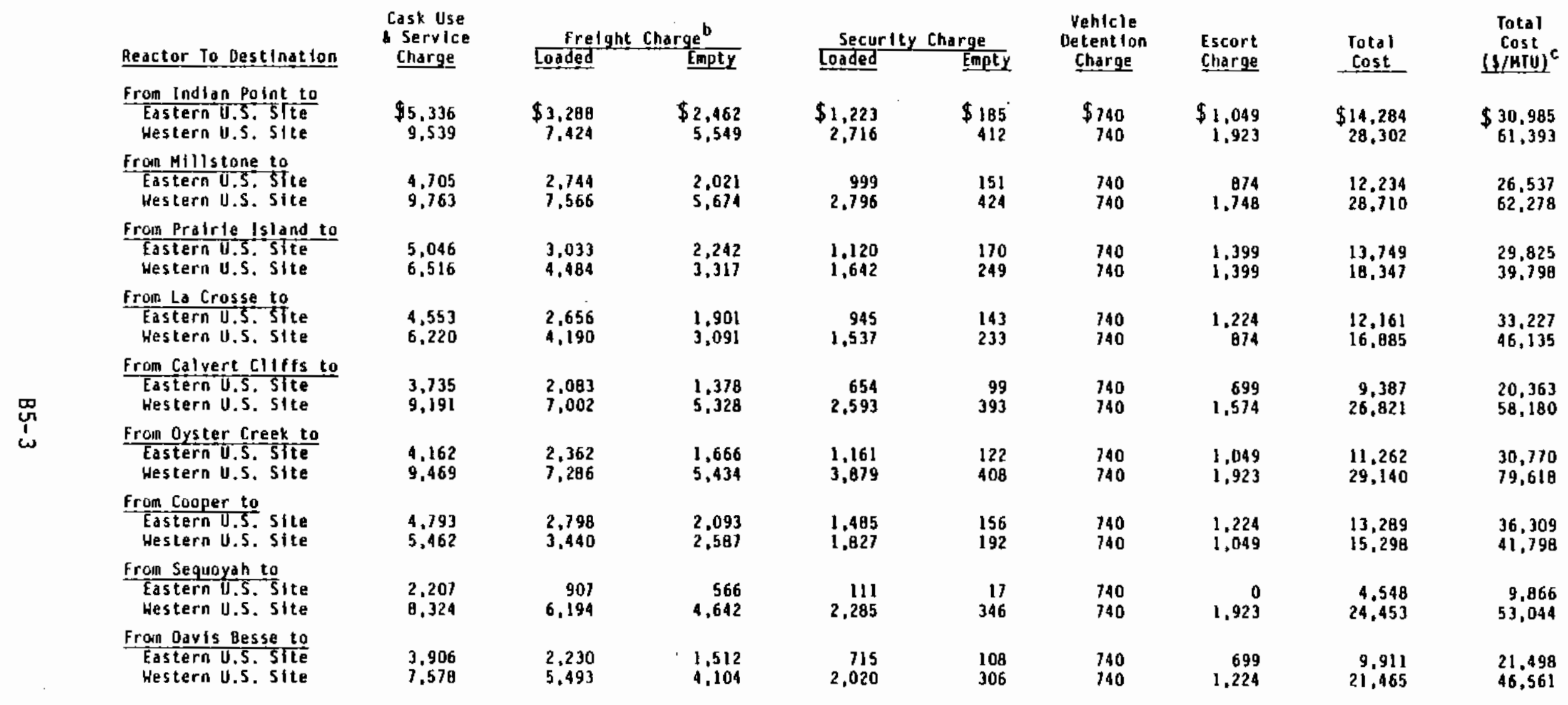

Based on use of HLI $1 / 2$ truck cask with capacity for elther one PUR or two BWR fuel assemblies.

based on 49,000 lb gross shipping weight loaded, and 48,000 lb gross shipping weiglit empty. CBased on 0.461 HTU/PHA asseably and 0.183 HTU/BHA assellbly, as introduced into the reactor. unit cost will increase or decrease proportionately
to corresponding decreases or increases in the uraniun content of the fuel assemblfes. 
IABLE 85-?

ESTIHAIED COSIS OF RAIL SIIIPMEMT OF SPENT HUCLEAR FUEL

(1987 Dollars)

Reactor to Destination

From Surry to

Estern U.5. Site Hestern U.S. Site

From Pallsades to Eastern U.5. STte 5. Sit

Fron St. Lucle to Eastern U.S. STte Western U.S. Site

From Robinson 10

Eastern U.S. Site

Western U.S. Site

Eastern U. S. STt Hestern U.S. Site

From Lasalle to

Eostern U.S. Site

Hestern U.S. Site

From Oconee to

Eastern U.S. Site

stern U.S. Site

Fran Peach Bottom to Hestern U.S. Site

From Pilgrim to

Eastern U.5. Site Hestern U.S. Site

\begin{tabular}{|c|c|c|c|c|c|}
\hline $\begin{array}{l}\text { Cask Use } \\
\text { s Service } \\
\text { Charge }\end{array}$ & $\begin{array}{l}\text { lleavy } \\
\text { llaul } \\
\text { Charge }\end{array}$ & $\begin{array}{l}\text { Rall } \\
\text { Frelght } \\
\text { Charge }\end{array}$ & $\begin{array}{l}\text { Escort } \\
\text { Charge }\end{array}$ & $\begin{array}{r}\text { Total } \\
\text { Cost? } \\
\end{array}$ & $\begin{array}{c}\text { Unit } \\
\text { Cost } \\
\text { IHIUL }\end{array}$ \\
\hline $\begin{array}{r}54,612 \\
130,909\end{array}$ & $\begin{array}{r}9,970 \\
19,440\end{array}$ & $\begin{array}{r}\$ 19,768 \\
54,481\end{array}$ & $\begin{array}{l}\$ 4,576 \\
13,846\end{array}$ & $\begin{array}{r}80,926 \\
218,676\end{array}$ & $\begin{array}{r}\$ 27,557 \\
67,764\end{array}$ \\
\hline $\begin{array}{l}51.370 \\
98.024\end{array}$ & $\begin{array}{r}0 \\
9.469\end{array}$ & $\begin{array}{l}20,547 \\
42,862\end{array}$ & $\begin{array}{l}4,399 \\
9,917\end{array}$ & $\begin{array}{r}76,316 \\
160,273\end{array}$ & $\begin{array}{l}23,649 \\
49,666\end{array}$ \\
\hline $\begin{array}{r}60.488 \\
129.493\end{array}$ & $\begin{array}{r}9,091 \\
18,560\end{array}$ & $\begin{array}{l}24,113 \\
56,184\end{array}$ & $\begin{array}{r}5,383 \\
13.935\end{array}$ & $\begin{array}{r}99,075 \\
218,172\end{array}$ & $\begin{array}{l}30.702 \\
67.600\end{array}$ \\
\hline $\begin{array}{r}51.704 \\
128.157\end{array}$ & $\begin{array}{r}0 \\
9,469\end{array}$ & $\begin{array}{l}16,565 \\
53,749\end{array}$ & $\begin{array}{r}4,268 \\
13,575\end{array}$ & $\begin{array}{r}72,557 \\
204,950\end{array}$ & $\begin{array}{l}22,484 \\
63,511\end{array}$ \\
\hline $\begin{array}{r}51,354 \\
127,839\end{array}$ & $\begin{array}{r}0 \\
9,469\end{array}$ & $\begin{array}{l}18,622 \\
55,244\end{array}$ & $\begin{array}{r}4,312 \\
13.714\end{array}$ & $\begin{array}{r}74,288 \\
206,267\end{array}$ & $\begin{array}{l}22,553 \\
62,619\end{array}$ \\
\hline $\begin{array}{l}58,800 \\
98,200\end{array}$ & $\begin{array}{r}0 \\
9.469\end{array}$ & $\begin{array}{l}18,527 \\
40,427\end{array}$ & $\begin{array}{l}5,124 \\
9,833\end{array}$ & $\begin{array}{r}02,451 \\
157,929\end{array}$ & $\begin{array}{l}25,031 \\
47,944\end{array}$ \\
\hline $\begin{array}{r}53,126 \\
129,462\end{array}$ & $\begin{array}{r}8,938 \\
18,407\end{array}$ & $\begin{array}{l}14,484 \\
50,534\end{array}$ & $\begin{array}{r}4,200 \\
13,515\end{array}$ & $\begin{array}{r}80.748 \\
211.919\end{array}$ & $\begin{array}{l}25,023 \\
65,670\end{array}$ \\
\hline $\begin{array}{r}66,422 \\
128,068\end{array}$ & $\begin{array}{r}0 \\
9,469\end{array}$ & $\begin{array}{l}20,930 \\
52,396\end{array}$ & $\begin{array}{r}6,008 \\
13,564\end{array}$ & $\begin{array}{r}93.360 \\
203.497\end{array}$ & $\begin{array}{l}28,342 \\
61,778\end{array}$ \\
\hline $\begin{array}{r}75,860 \\
141,123\end{array}$ & $\begin{array}{r}9,475 \\
16,944\end{array}$ & $\begin{array}{l}27,789 \\
55,961\end{array}$ & $\begin{array}{r}7,179 \\
15,024\end{array}$ & $\begin{array}{l}120,304 \\
231,052\end{array}$ & $\begin{array}{l}36,522 \\
70,143\end{array}$ \\
\hline
\end{tabular}


TABLE B5-2 (Continued)

ESTIMATED COSTS OF RAIL SIIPMENT OF SPENT MUCLEAR FUEL a

(1987 Dollars)

\begin{tabular}{|c|c|c|c|c|c|c|}
\hline Reactor to Destination & $\begin{array}{l}\text { Cask Use } \\
\text { S Service } \\
\text { Charge } \\
\end{array}$ & $\begin{array}{l}\text { lleavy } \\
\text { llaul } \\
\text { Charge }\end{array}$ & $\begin{array}{l}\text { Rail } \\
\text { Freight } \\
\text { Charge }\end{array}$ & $\begin{array}{l}\text { Escort } \\
\text { Charge } \\
\end{array}$ & $\begin{array}{l}\text { Total } \\
\text { Cost } \\
\end{array}$ & $\begin{array}{r}\text { Unit } \\
\text { Cost } \\
\text { (\$MTU C }\end{array}$ \\
\hline $\begin{array}{l}\text { From lndian Point to } \\
\text { Eastern U.S. Site } \\
\text { Hestern U.S. Site }\end{array}$ & $\begin{array}{r}\$ 67,372 \\
129,126\end{array}$ & $\begin{array}{r}\$ 8,784 \\
18,253\end{array}$ & $\begin{array}{r}\$ 24,941 \\
54,063\end{array}$ & $\begin{array}{r}\$ 6,124 \\
13,657\end{array}$ & $\begin{array}{r}\$ 107,221 \\
215,899\end{array}$ & $\begin{array}{r}\$ 33,226 \\
66,904\end{array}$ \\
\hline $\begin{array}{l}\text { Froin Millstone to } \\
\text { Eastern U.S. STte } \\
\text { Hestern U.S. Site }\end{array}$ & $\begin{array}{r}67,572 \\
129,493\end{array}$ & $\begin{array}{r}8,806 \\
18,275\end{array}$ & $\begin{array}{l}26,532 \\
55,961\end{array}$ & $\begin{array}{r}6,224 \\
13,792\end{array}$ & $\begin{array}{l}109.133 \\
217.521\end{array}$ & $\begin{array}{l}33,819 \\
67,407\end{array}$ \\
\hline $\begin{array}{l}\text { Froin Prairie Islond to } \\
\text { Eastern U.S. Site } \\
\text { Hestern U.S. Site }\end{array}$ & $\begin{array}{l}58.926 \\
87,434\end{array}$ & $\begin{array}{r}0 \\
9.469\end{array}$ & $\begin{array}{l}27,360 \\
38,437\end{array}$ & $\begin{array}{l}5,437 \\
8,484\end{array}$ & $\begin{array}{r}91,722 \\
143,825\end{array}$ & $\begin{array}{l}28,423 \\
44,569\end{array}$ \\
\hline $\begin{array}{l}\text { Fron La Crosse to } \\
\text { Eastern i.5. Site } \\
\text { Hestern U.S. Site }\end{array}$ & $\begin{array}{l}50,800 \\
86,909\end{array}$ & $\begin{array}{r}0 \\
9.469\end{array}$ & $\begin{array}{l}25,673 \\
39,010\end{array}$ & $\begin{array}{l}5,347 \\
8,474\end{array}$ & $\begin{array}{r}89,820 \\
143.863\end{array}$ & $\begin{array}{l}27,268 \\
43,674\end{array}$ \\
\hline $\begin{array}{l}\text { Frola Calvert Cliffs to } \\
\text { Eastern U.S. S1te } \\
\text { Western U.S. Site }\end{array}$ & $\begin{array}{r}55,154 \\
130,959\end{array}$ & $\begin{array}{l}11.133 \\
20.603\end{array}$ & $\begin{array}{l}20,213 \\
52,814\end{array}$ & $\begin{array}{r}4,645 \\
13,717\end{array}$ & $\begin{array}{r}91,146 \\
218,153\end{array}$ & $\begin{array}{l}28,245 \\
67,602\end{array}$ \\
\hline $\begin{array}{l}\text { From Oyster Creek to } \\
\text { Eastern U.S. Site } \\
\text { Hestern U.S. Site }\end{array}$ & $\begin{array}{r}62,478 \\
129,665\end{array}$ & $\begin{array}{l}10,118 \\
19,587\end{array}$ & $\begin{array}{l}23,381 \\
54,481\end{array}$ & $\begin{array}{r}5,401 \\
13,732\end{array}$ & $\begin{array}{l}101,378 \\
217,466\end{array}$ & $\begin{array}{l}30,777 \\
66,019\end{array}$ \\
\hline $\begin{array}{l}\text { Erom Cooper to } \\
\text { Eastern U.S. Site } \\
\text { Western U.S. Site }\end{array}$ & $\begin{array}{l}58,800 \\
87,325\end{array}$ & $\begin{array}{r}0 \\
9.469\end{array}$ & $\begin{array}{l}27.360 \\
33.424\end{array}$ & $\begin{array}{l}5.442 \\
6.327\end{array}$ & $\begin{array}{r}91,602 \\
138,545\end{array}$ & $\begin{array}{l}27,009 \\
42,060\end{array}$ \\
\hline $\begin{array}{l}\text { Eroun Sequoyah to } \\
\text { Eastern U.S. Site } \\
\text { Hestern U.S. Site }\end{array}$ & $\begin{array}{r}39.966 \\
126.921\end{array}$ & $\begin{array}{r}0 \\
9.469\end{array}$ & $\begin{array}{r}9,868 \\
47,064\end{array}$ & $\begin{array}{r}2,813 \\
13,187\end{array}$ & $\begin{array}{r}52,647 \\
196,641\end{array}$ & $\begin{array}{l}16,314 \\
60,936\end{array}$ \\
\hline $\begin{array}{l}\text { Erom Davis besse to } \\
\text { Eastern U.S. Site } \\
\text { Hestern U.S. Site }\end{array}$ & $\begin{array}{l}51,208 \\
91,847\end{array}$ & $\begin{array}{r}0 \\
9.469\end{array}$ & $\begin{array}{l}17,794 \\
45,130\end{array}$ & $\begin{array}{r}4.270 \\
10,086\end{array}$ & $\begin{array}{r}73,272 \\
162,540\end{array}$ & $\begin{array}{l}22,706 \\
50,369\end{array}$ \\
\hline
\end{tabular}

\footnotetext{
aased on use of If-300 rall cask with capacity for elther 7 PUR or 18 QWR fuel assemblies.

based on 164,000 lo gross shippling weight loaded, and 154,000 lb gross shipping weight enpty. Reductions in rall freiglit charges may be possible through individual case negotiations with the rallrads.

CBased on 0.461 MTU/PHR assembly and 0.103 MTU/BWR assembly, as Introduced into the reactor. Unit cost

will increase or decrease proportionately to corresponding decreases or increases in the uranium content

of the fuel asseinblies.
} 
.

$\therefore$

.

. 


\section{EXHIBIT C}

FIS SPENT FUEL ACCEPTANCE CRITERIA 


\section{EXHI8IT C}

FIS SPENT FUEL ACCEPTANCE CRITERIA

\section{$1.0 \quad$ GENERAL CRITERIA}

The following sets forth the general criteria applicable to spent fuel acceptance for FIS:

(1) The spent fuel shall have been used only in a commercial nuclear power plant operated in the United States.

(2). The overall length of any PWR fuel assembly, or any canister of consolidated PWR fuel rods, shall not exceed 179-inches. The overall length of any BWR fuel assembly, or any canister of consolidated BWR fuel rods, shall not exceed 179-inches.

(3) The maximum cross-sectional envelope dimension of any PWR assembly, or any canister of consolidated PWR fuel rods, shati not exceed 9-inches. The maximum cross-sectional envelope dimension of any BWR assembly, or any canister of consolidated 8 WR fuel rods, shall not exceed 6 -inches.

(4) The spent fuel shall not be defective, as defined in Section 2.0 of this Exhibit $C$.

(5) The uranium contained in the spent fuel prior to irradiation shall not contain more than $3.5 \%$ uranium-235.

(6) The spent fuel assemblies and the spent fuel assemblies from which canistered consolidated rods originated shall not have a thermal output in excess of $\mathrm{l} \mathrm{kW} / \mathrm{assembly}$ for PWR fuel and $0.4 \mathrm{kN} / \mathrm{assembily} \mathrm{for} \mathrm{BWR} \mathrm{fuel.}$

(7) The canister used to contain consolidated fuel rods shall be constructed of stainless steel, shall be no less than a nominal 3/16-inch in thickness and shall be sealed by either welding or a metal-gasketed flange. The canister shall be free of residual water.

(8) A detailed description of the spent fuel assemblies or canistered spent fuel rods, in both the form and detail prescribed by the Department, shall be submitted by the owner of the reactor from which the fuel was discharged. This description shall be examined by the Department and the Department shall have made a written finding that the spent fuel is compatible with handling and storage capabilities of the FIS facilities. 

$2.0 \quad$ NON-DEFECTIVE FUEL

Non-defective fuel shall be defined as:

(1) spent fuel assemblies which meet the general specifications set forth in Section 1.0 of this Exhibit $C$, which have been visually examined using underwater periscopes and/or remote TV scanning over the futl length of all sides of the fuel assembly, no earlier than 180 days prior to the scheduled date of delivery to the Department, and which show no obvious evidence of existence of any of the following conditions to an extent wich would require special handling or encapsulation at the FIS facility:
(a) fuel rod distortion
(b) cladding rupture or deterioration
(c) structural damage
(d) other condition of either the fuei rod(s) or assemily structure that is likely to result in (a) through (c), above, during transport to the FIS facilities or to interfere with the routine handing of the spent fuel assemblies at the FIS.

(2) canisters of consolidated fuel rods, which meet the general specifications set forth in Section 1.0 of this Exhibit C, and which have been pressure tested, no earlier than 90 days prior to the scheduled date of delivery to the Department, and have been found to lose no pressure over a period of 4 hours when pressurized to no less than 50 psig.

(3) spent fuel assemblies and canisters of consolidated fuel rods, meeting the applicable requirements of (1); above, for which certifications have been submitted to the Department regarding the details of the measurements and observations made and the results thereof.

(4) spent fuel assemblies and canisters of consolidated fuel rods, meeting the applicable requirements of (1), (2) and (3), above, and which have been determined by the Department to be in condition suitable for storage after receipt at the FIS facilities.

(5) spent fuel assemblies and canisters of consolidated fuel rods meeting the general specifications set forth in Section 1.0 of this Exhibit $C$ and the applicable requirements of (1), (2), (3) and (4), above, and (a) for which the utility has performed a calculation of the expected themal emission rate and shall have verified that no fuel assembly to be delivered to the 
Department in the form of fuel as spent fuel assemblies or canistered consalidated spent fuel rods exceeds the maximum value set forth in Section 1.0(6) of this Exhibit $C$, and the Purchaser has delivered to the Department the analysis of the expected thema? emission rate of the spent fuel assembly or canister of consolidated fuel rods as of no earlier than 90 days before the date of delivery of the spent fuel to the Department, or (b) for which the utility has delivered a certification to the Department that no assembly to be delivered for FIS has been discharged from the reactor for less than 8 years. 
OISTR IBUTION

No. of

Copies

\section{OFFSITE}

R. W. Bown

$R \mathrm{~W}-30$

Dffice of Civilian Radioactive Waste Management

U.S. Department of Energy

Washington, DC 20545

J. R. Hilley

$R W-30$

Office of Civilian Radioactive Waste Management

U.S. Department of Energy

Washington, DC 20545

K. A. Klein

RW-32

Office of Civilian Radioactive Waste Management

U.S. Department of Energy

Washington, OC 20545

L. Barrett

RW-33

Office of Civilian Radioactive Waste Management

U.S. Department of Energy

Washington, DC 20545

50

D. E. Shelor

RW-32

Office of Civilian Radioactive Waste Management

U.S. Department of Energy

Washington, DC 20545

\section{R. Milner}

$\mathrm{RW}-12$

Office of Civilian Radioactive Waste Management

U.S. Department of Energy

Washington, DC 20545
No. of

Copies

T. W. Wood

Battelle Memorial Institute

Washington Operations

$2030 \mathrm{M}$ Street $-\mathrm{NW}$

Suite 800

Washington, DC 20036

R. F. Williams

Electric Power Research Institute

P.0. Box 10412

Palo Alto, CA 94304

10 E. R. Johnson Associates, Inc.

11702 Bowman Green Orive

Reston, VA 22090

30

DOE Technical Information Center

ONSITE

9 DOE Richland Operations Of fice

J. P. Collins

D. E. Crouter (5)

R. D. Izatt

D. C. Langstaff

R. R. Tibbatts

43 Pacific Northwest Laboratory

W. J. Bailey

W. W. Ballard

G. H. Beeman

J. L. Braitman

B. M. Cole

J. M. Creer

P. M. Daling

R. L. Engel

J. F. Fletcher

E. R. Gilbert

M. W. Gladstone

C. M. Heeb (10)

R. E. Heineman 
No, of

Copies

G. M. Holter

M. R. Kreiter

A. B. Johnson

R. A. Libby

J. L. MCElroy

$D$. F. Newman

K. J. Schneider

M. R. Shay

D. J. Silviera

L. A. Strope

R. C. Walling

E. V. Werry (2)

M. K. White

Publishing Coordination (2)

Technical Coordination (5) 